LAB-RPT-12-00008

Revision 0

\title{
Boildown Study on Supernatant Liquid Retrieved from AP-107 in May 2010
}

\section{W. S. Callaway}

J. S. Page

Washington River Protection Solutions LLC

Date Published

January 2013

\section{washington river} protectionsolutions

Prepared for the U.S. Department of Energy

Office of River Protection

Contract No. DE-AC27-08RV14800 
LAB-RPT-12-00008

Revision 5

TRADEMARK DISCLAIMER

Reference herein to any specific commercial product, process, or service by tradename, trademark, manufacturer, or otherwise, does not necessarily

constitute or imply its endorsement, recommendation, or favoring by the

United States Government or any agency thereof or its contractors or subcontractors.

This report has been reproduced from the best available copy.

Printed in the United States of America 


\section{EXECUTIVE SUMMARY}

A boildown study was completed on a composite prepared from supernatant liquid grab samples retrieved from tank 241-AP-107 in May of 2010. The composite was a clear, yellow liquid containing no visible solids at hot cell ambient temperatures $\left(25-27^{\circ} \mathrm{C}\right)$. The density of the test composite was $1.216 \mathrm{~g} / \mathrm{mL}$ at $26.8^{\circ} \mathrm{C}$.

The boiling temperature curves generated at three reduced pressures-40-, 60-, and 80 Torrdisplayed steadily increasing boiling temperatures with increasing volume reduction with no significant discontinuities. Only minimal foaming was observed after the volume reduction proceeded beyond $50 \% \mathrm{WVR}$ (percent waste volume reduction).

The bulk densities $\left(\mathrm{D}_{\text {Bulk }}{ }^{1{ }^{\circ} \mathrm{C}}\right)$ and quantities of settled and centrifuged solids present were measured on samples of the boildown concentrates that were kept at $18{ }^{\circ} \mathrm{C}$ for $7-8$ days. Estimated values of the bulk densities of the concentrates at 60-Torr boiling temperatures $\left(\mathrm{D}_{\text {Bulk }}{ }^{60 \text { Torr }}\right)$ were also calculated. The densities and solids content of concentrates at four levels of volume reduction were:

\begin{tabular}{|l|c|c|c|c|}
\hline$\% W V R$ & 27.7 & 46.0 & 54.0 & 57.5 \\
\hline $\mathrm{D}_{\text {Bulk }}^{18^{\circ} \mathrm{C}}$ (measured) & 1.294 & 1.387 & 1.447 & 1.484 \\
\hline $\mathrm{D}_{\text {Bulk }}{ }^{60 \text { Torr }}$ (estimated) & 1.277 & 1.366 & 1.425 & 1.464 \\
\hline${\text { Vol\% Settled Solids }\left(18^{\circ} \mathrm{C}\right)}^{\text {Vol\% Centrifuged Solids }\left(18^{\circ} \mathrm{C}\right)}$ & 4.5 & 10.4 & 15.5 & 76.2 \\
\hline
\end{tabular}

Solids were observed in all boildown concentrates at process temperatures, at hot cell ambient temperatures $\left(25-27^{\circ} \mathrm{C}\right)$, and at $18{ }^{\circ} \mathrm{C}$. The quantity of solids found in the cooled concentrates increased slowly through 50.2\%WVR. The quantity of solids found in concentrates after $54.0 \% \mathrm{WVR}$ was noticeably greater. Beyond $54.0 \% \mathrm{WVR}$, the quantity of solids found in cooled concentrates increased dramatically.

Analysis of boildown test samples indicated that sodium oxalate and sodium carbonate solids form in cooled concentrates after volume reduction of $8.4 \% \mathrm{WVR}$ or less.

After $50 \% \mathrm{WVR}$, the solids formed in cooled concentrates contained:

$>90 \%$ of the oxalate and fluoride present in the initial tank $241-\mathrm{AP}-107$ feed composite as sodium oxalate, sodium fluoride phosphate, and sodium fluoride sulfate.

$\approx 59 \%$ of the phosphate and $\approx 24 \%$ of the sulfate in the initial composite as sodium fluoride phosphate and sodium fluoride sulfate.

$\approx 7 \%$ each of the nitrate, nitrite, and carbonate in the starting composite as sodium nitrate, sodium nitrite, and sodium carbonate salts.

The major contributors to the large increase in the quantity of solids found in concentrates after $54 \%$ WVR were sodium nitrate and sodium carbonate. 


\section{TABLE OF CONTENTS}

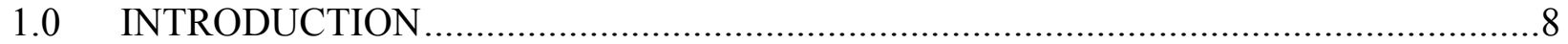

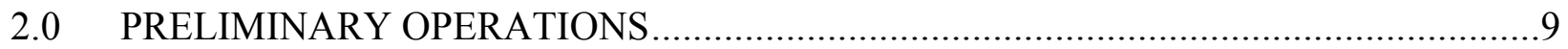

2.1 PREPARATION OF TEST COMPOSITE ...........................................................

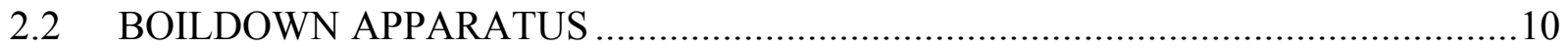

2.2.1 Temperature Sensor ....................................................................... 10

2.2.2 Pressure Sensor/Controller .................................................................. 11

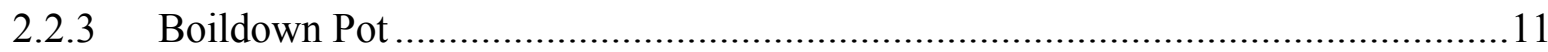

2.2.4 Centrifuge Cones ................................................................................. 11

3.0 TEST OPERATIONS AND RESULTS ................................................................ 12

3.1 HOT CELL TEST OPERATIONS ................................................................... 12

3.1.1 Boildown Progress Parameters ................................................................ 12

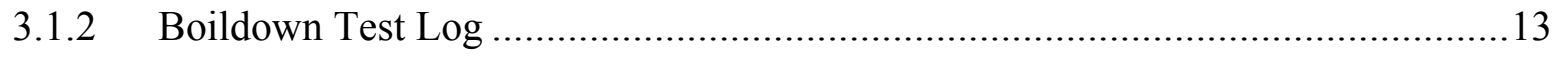

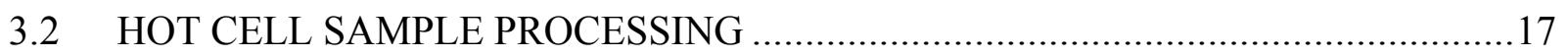

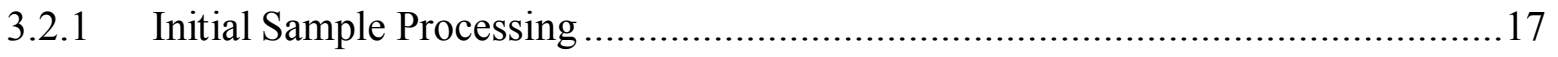

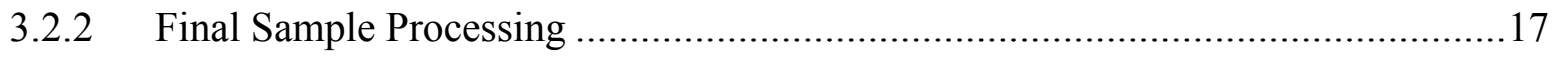

3.2.3 Densities of Boildown Sample Liquids ....................................................21

3.3 FINAL VOLUME AND WEIGHT DATA...........................................................21

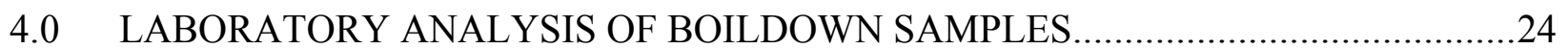

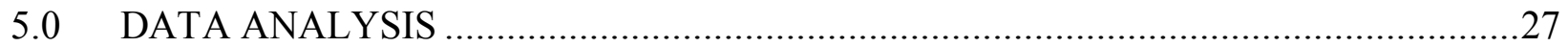

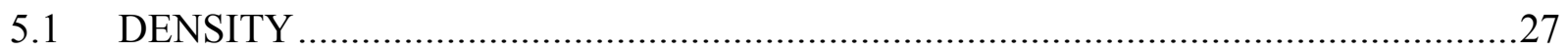

5.1.1 Bulk Density of Boildown Samples................................................................27

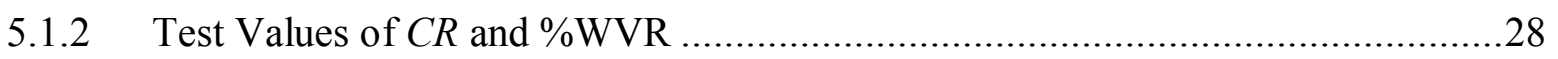

5.1.3 Volumes and Densities at Process Temperatures ...............................................30

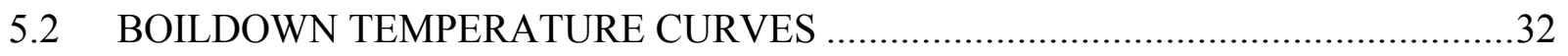

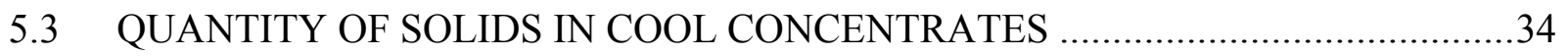

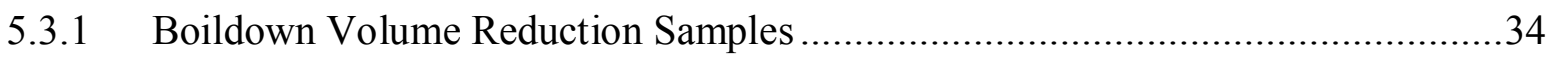

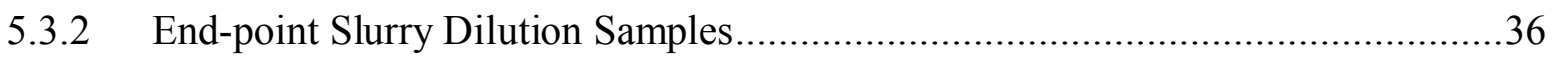

5.3.3 Calculated Weights of Solids in Boildown Samples ..........................................37

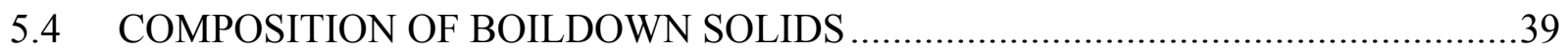

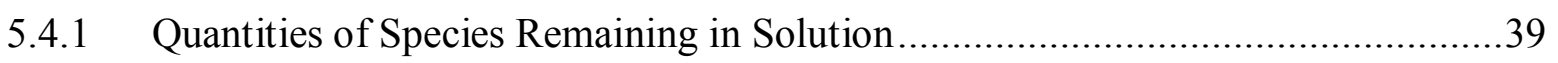

5.4.2 Solid Phase Characterization Results.........................................................4 48

5.4.3 Solid Phases Present in Concentrate Solids ....................................................51

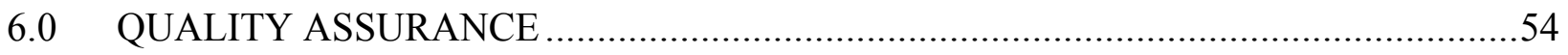




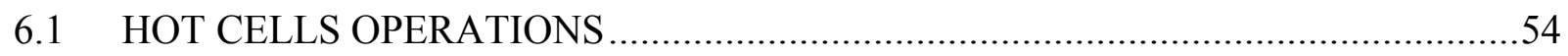

6.2 LABORATORY ANALYSES ................................................................5

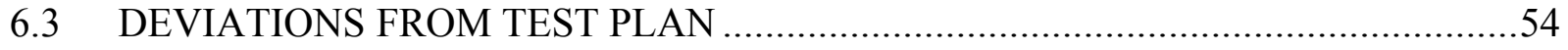

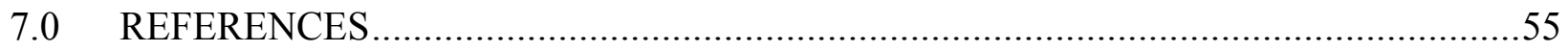

ATTACHMENT A - Volume Calibration of Centrifuge Cones

ATTACHMENT B - Boildown Hot Cell Data Logs

ATTACHMENT C - Photographs of Boildown Samples

ATTACHMENT D - Laboratory Analysis Results

ATTACHMENT E - Solid Phase Characterization of Boildown Solids

\section{List of Figures}

Figure 3-1. Appearance of the Composite During Boildown Test. .........................................15

Figure 3-2. Density of Sample Liquids versus Boildown Progress......................................23

Figure 5-1. Comparison of Model and Measured Bulk Densities. ......................................28

Figure 5-2. Bulk Densities at $18{ }^{\circ} \mathrm{C}$ versus Concentration Ratio...............................................30

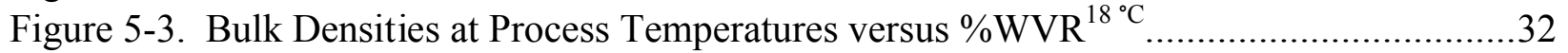

Figure 5-4. Boiling Temperature versus Boildown Progress. .................................................33

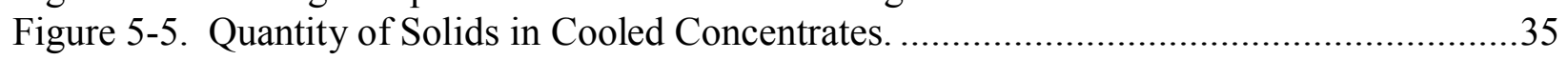

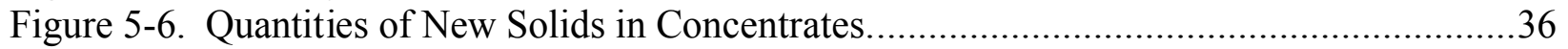

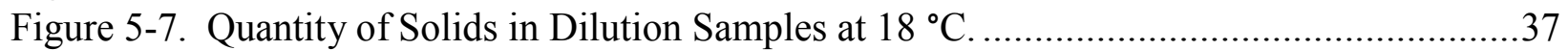

Figure 5-8. Calculated and Measured Weights of Solids in Concentrates................................39

Figure 5-9. Weights of Species Remaining in Solution at $18{ }^{\circ} \mathrm{C}$..........................................41

Figure 5-10. Estimated Weights of Species in $18{ }^{\circ} \mathrm{C}$ Solids. ...............................................47

Figure 5-11. Estimated Vol\% of Solid Phases in Concentrate Solids......................................52 


\section{LAB-RPT-12-00008, R0}

\section{List of Tables}

Table 2-1. Preparation of Composite for Boildown Study...................................................9

Table 2-2. Density of Composite Measured in Hot Cell................................................. 10

Table 3-1. Appearance of Settled Solids in Boildown Samples...........................................18

Table 3-2. Identification of Boildown Samples.........................................................20

Table 3-3. Gravimetric and Volumetric Data for Boildown Samples. ..................................22

Table 4-1. Results of Analyses of Boildown Sample Liquids..............................................25

Table 5-1. Calculation of Test Values of $C R$ and \%WVR ..................................................29

Table 5-2. Adjusted Sample Volumes and Densities at Process Temperatures. ........................31

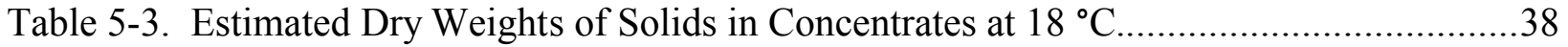

Table 5-4. Solid Phases Identified in C-Slds Samples............................................................49 


\section{LIST OF TERMS}

\begin{tabular}{|c|c|}
\hline \multicolumn{2}{|c|}{ Abbreviations and Acronyms } \\
\hline $222-\mathrm{S}$ & [WRPS] 222-S Laboratory \\
\hline ATL & Advanced Technologies and Laboratories International, Inc. \\
\hline AP-107 & tank 241-AP-107 \\
\hline C-Liq & centrifuged liquid \\
\hline C-Sld(s) & centrifuged solid(s) \\
\hline $\mathrm{CON} \#$ & step or sample number in boildown volume reduction \\
\hline$C R$ & cumulative concentration ratio \\
\hline$C R^{\circ} \mathrm{C}$ & cumulative concentration ratio at indicated temperature \\
\hline$C R_{\text {Model }}{ }^{\circ} \mathrm{C}$ & $\begin{array}{l}\text { cumulative concentration ratio at indicated temperature calculated using } \\
\text { additive volumes model }\end{array}$ \\
\hline$C R_{\text {Step }}$ & concentration ratio for a discrete step in a boildown test sequence \\
\hline $\mathrm{D}$ & density \\
\hline $\mathrm{D}_{\text {Bulk }}$ & bulk density (i.e. total density of a sample containing liquid and solids) \\
\hline $\mathrm{D}_{\text {Bulk }}{ }^{\circ} \mathrm{C}$ & bulk density at indicated temperature \\
\hline $\mathrm{D}_{\text {Bulk }} 60$ Torr & estimated bulk density at boiling temperature at 60 Torr \\
\hline $\mathrm{D}_{\text {Liq }}{ }^{\circ} \mathrm{C}$ & liquid density at indicated temperature \\
\hline $\mathrm{D}_{\text {Model }}{ }^{\circ} \mathrm{C}$ & density at indicated temperature calculated using additive volumes model \\
\hline DIL \# & step or sample number in dilution of end-point slurry \\
\hline IC & ion chromatography \\
\hline ICP-AES & inductively coupled plasma-atomic emission spectrometry \\
\hline Liq & liquid(s) \\
\hline MDL & minimum detection limit \\
\hline MDW & minimum detectable weight \\
\hline & National Institute of Standards and Technology \\
\hline$\%$-Rec & percent recovery \\
\hline$\%$ WVR & percent waste volume reduction \\
\hline$\% \mathrm{WVR}{ }^{\circ} \mathrm{C}$ & percent waste volume reduction at indicated temperature \\
\hline$\% \mathrm{WVR}_{\text {Model }}{ }^{\circ} \mathrm{C}$ & $\begin{array}{l}\text { percent waste volume reduction at indicated temperature calculated using } \\
\text { additive volumes model }\end{array}$ \\
\hline$P_{\text {Read }}$ & pressure as read from transducer display \\
\hline $\mathrm{P}_{\text {Corrected }}$ or $\mathrm{P}_{\text {Corr }}$ & corrected system pressure \\
\hline $\mathrm{P} / \mathrm{T}$ & combination measurement of boiling temperature at specified pressure \\
\hline PLM & polarized light microscopy \\
\hline Pt-RTD & platinum resistance temperature detector \\
\hline RPD & relative percent difference \\
\hline SEM/EDX & scanning electron microscopy with energy dispersive X-ray spectroscopy \\
\hline Slds & solids \\
\hline S-Sld(s) & settled solid(s) \\
\hline $\mathrm{SPC}$ & solid phase characterization \\
\hline $\mathrm{SpG}$ & specific gravity \\
\hline $\mathrm{T}$ & temperature \\
\hline $\mathrm{T}_{\text {Read }}$ & temperature as read from thermocouple display \\
\hline $\mathrm{T}_{\text {Corrected }}$ or $\mathrm{T}_{\text {Corr }}$ & corrected system temperature \\
\hline
\end{tabular}




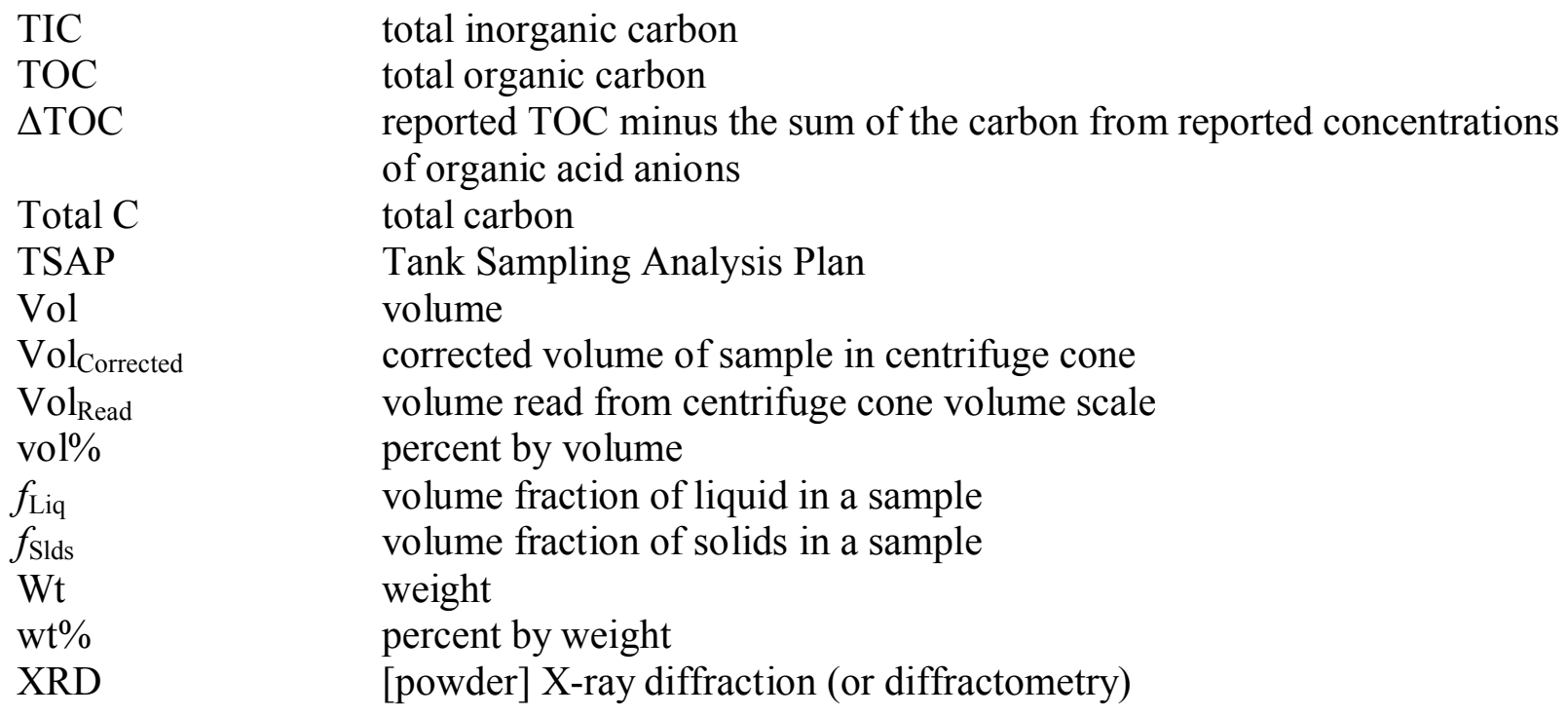

\section{Units}

$\begin{array}{ll}{ }^{\circ} \mathrm{C} & \text { degree(s) Celcius } \\ \mathrm{cm} & \text { centimeter(s) } \\ g & \text { acceleration due to gravity (used to define relative centrifugal force) } \\ \mathrm{g} & \text { grams } \\ \mathrm{g} / \mathrm{L} & \text { grams per liter } \\ \mathrm{g} / \mathrm{mL} & \text { grams per milliliter } \\ \mathrm{kV} & \text { kilovolts } \\ \mathrm{hr}(\mathrm{s}) & \text { hour(s) } \\ \mathrm{L} & \text { liter(s) } \\ \mu \mathrm{m} & \text { micrometer } \\ \mu \mathrm{g} / \mathrm{mL} & \text { micrograms per milliliter } \\ \mathrm{mL} & \text { milliliter } \\ (\Delta \mathrm{mL} / \mathrm{mL}) /{ }^{\circ} \mathrm{C} & \text { change in volume (in milliliters) per milliliter of solution per change in } \\ & \text { degrees Celcius (units of thermal expansion coefficient) } \\ \mathrm{mm} & \text { millimeter } \\ \text { Torr } & \text { unit of pressure equivalent to } 1 \mathrm{~mm} \mathrm{Hg}\end{array}$




\subsection{INTRODUCTION}

This report presents the results of a boildown study performed at the 222-S Laboratory (222-S) on supernatant liquid retrieved from tank 241-AP-107 (AP-107) in May of 2010. This study examined the behavior of the retrieved supernatant liquid during volume reduction under reduced pressures as requested in the tank sampling and analysis plan (TSAP) prepared to support operations at the 242-A Evaporator (RPP-PLAN-40837, Tank 241-AP-107 Grab Sampling and Analysis Plan in Support of Evaporator Campaign for Fiscal Year 2010). The boildown study was performed in hot cells $11 \mathrm{~A}-5$ and $11 \mathrm{~A}-6$ at $222-\mathrm{S}$. The study was conducted in accordance with the customer-approved test plan (LAB-PLN-10-00007, Test Plan for Boildown Study on Supernate Retrieved from 241-AP-107 in May 2010). Test operations altering the volume of the AP-107 liquid waste sample were performed as described in Laboratory Technology Procedure ATS-LT-519-183, "222-S Laboratory Determination of Properties of Radiological Solutions as a Function of Volume Reduction at Reduced Pressure."

The boildown study was a vacuum distillation of a composite of the AP-107 supernatant liquid grab samples at client-approved pressures of 40,60, and 80 Torr (mm Hg). It was designed (1) to determine the relationship between solids formation and percent waste volume reduction (\%WVR), (2) to determine the relationship between concentrate density and \%WVR, (3) to determine the type and quantity of solids that may form in the AP-107 concentrates after cooling to ambient temperatures in storage tanks, and (4) to define the relationship between boiling temperature and concentration of the pot liquor/slurry. To obtain this information, the boildown study progressed through four stages:

Composite preparation

Boildown concentration

End-point slurry dilution

Sample processing
A composite of the AP-107 supernatant liquid waste was prepared from grab samples retrieved in May of 2010.

Volume reduction of the AP-107 composite was performed at reduced pressures. Samples of pot liquor/slurry were withdrawn at sampling points defined by calculated densities of the concentrate.

The end-point slurry from the concentration sequence was rediluted, in increments, reconstituting the concentrates from early stages of the volume reduction.

Samples collected during the concentration and dilution sequences were processed and all physicochemical analyses completed. 


\subsection{PRELIMINARY OPERATIONS}

\subsection{PREPARATION OF TEST COMPOSITE}

A composite of the supernatant liquid grab samples retrieved from AP-107 in May 2010 was prepared on Semptember 22, 2011 as shown in Table 2-1. The composite was specified volumetrically and prepared gravimetrically. Density values reported for each grab sample by 222-S (RPP-RPT-47358, Final Report for Tank 241-AP-107 Liquid Grab Samples in Support of the Evaporator Program) were used to convert target volume additions to target weights. No appreciable solids were observed in any of the grab samples used to prepare the composite nor were any physical changes observed as the composite was prepared. The final composite was a yellow liquid that was very slightly cloudy but contained no visible solids. No changes were observed during the 11 days at hot cell ambient temperatures that preceeded the initiation of the boildown concentration sequence on October 3, 2011.

Table 2-1. Preparation of Composite for Boildown Study.

\begin{tabular}{|c|c|c|c|c|c|c|}
\hline \multicolumn{2}{|c|}{ Sample Number } & \multirow[b]{2}{*}{ Location } & \multirow[b]{2}{*}{ SpG $^{a}$} & \multicolumn{3}{|c|}{ Added to Composite } \\
\hline Grab Sample & OmniLIMS & & & g & $\mathrm{mL}^{\mathbf{b}}$ & Vol\% \\
\hline 7AP-10-01 & S10T002464 & Surface & 1.211 & - & - & - \\
\hline $7 \mathrm{AP}-10-02 \mathrm{~A}$ & S10T002472 & \multirow{2}{*}{$\begin{array}{l}\approx 1 / 6 \text { of distance } \\
\text { surface to solids }\end{array}$} & \multirow{2}{*}{1.209} & 121.145 & 100.203 & \multirow{2}{*}{33.27} \\
\hline $7 \mathrm{AP}-10-02 \mathrm{~B}$ & S10T002478 & & & 80.294 & 66.414 & \\
\hline $7 \mathrm{AP}-10-03 \mathrm{~A}$ & S10T002473 & \multirow{2}{*}{$\begin{array}{l}\approx 1 / 2 \text { of distance } \\
\text { surface to solids }\end{array}$} & \multirow{2}{*}{1.213} & 188.442 & 155.352 & \multirow{2}{*}{33.34} \\
\hline 7AP-10-03B & S10T002479 & & & 14.090 & 11.616 & \\
\hline $7 \mathrm{AP}-10-04 \mathrm{~A}$ & S10T002474 & \multirow{2}{*}{$\begin{array}{l}\approx 5 / 6 \text { of distance } \\
\text { surface to solids }\end{array}$} & \multirow{2}{*}{1.208} & 89.987 & 74.493 & \multirow{2}{*}{33.38} \\
\hline 7AP-10-04B & S10T002480 & & & 111.960 & 92.682 & \\
\hline Composite & S11T011047 & \multicolumn{2}{|l|}{ - } & 605.918 & 500.760 & 99.99 \\
\hline
\end{tabular}

OmniLIMS - 222-S Laboratory Information Management System

Vol\% - percent by volume

SpG - specific gravity

${ }^{\mathrm{a}}$ Values of specific gravity (SpG) measured and reported by the 222-S Laboratory.

${ }^{\mathrm{b}}$ Calculated volumes using weights added and reported $\mathrm{SpG}$ values.

The density of the test composite was measured in the 11A-6 hot cell as it was transferred to the glass pot in the boildown apparatus. The density measurement data is presented in Table 2-2. Three 100-mL Class A volumetric flasks were filled with the composite liquid and weighed. The temperature of the composite liquid was $26.8^{\circ} \mathrm{C}$. The average density of the AP-107 composite was $1.216 \pm 0.001 \mathrm{~g} / \mathrm{mL}$. 
Table 2-2. Density of Composite Measured in Hot Cell.

\begin{tabular}{|l|c|c|c|}
\hline & Flask A & Flask B & Flask C \\
\hline \multicolumn{3}{|c|}{ Reagent $\mathrm{H}_{2} \mathbf{O}$ (not deaerated) } \\
\hline Nominal flask volume $(\mathrm{mL})$ & \multicolumn{3}{|c|}{$100 \pm 0.08$} \\
\hline Wt reagent $\mathrm{H}_{2} \mathrm{O}$ to fill flask $(\mathrm{g})$ & 99.501 & 99.465 & 99.514 \\
\hline Temperature of $\mathrm{H}_{2} \mathrm{O}\left({ }^{\circ} \mathrm{C}\right)$ & \multicolumn{3}{|c|}{0.996485} \\
\hline Reference $\mathrm{H}_{2} \mathrm{O}$ density $(\mathrm{g} / \mathrm{mL})$ & 99.852 & 99.816 & 99.865 \\
\hline Corrected flask volume $(\mathrm{mL})$ & Composite \\
\hline \multicolumn{4}{|c|}{$1.216 \pm 0.001 \mathrm{~g} / \mathrm{mL}$} \\
\hline Wt composite to fill flask $(\mathrm{g})$ & 121.529 & 121.329 & 121.371 \\
\hline Calculated composite density $(\mathrm{g} / \mathrm{mL})$ & 1.2171 & 1.2155 & 1.2154 \\
\hline Temperature of composite $\left({ }^{\circ} \mathrm{C}\right)$ & $\mathrm{g}$ & 26.8 \\
\hline Average composite density $(\mathrm{g} / \mathrm{mL})$ & &
\end{tabular}

On September 28, 2011 a sample of the AP-107 composite was collected for physicochemical analyses. Approximately $12 \mathrm{~mL}$ of the sample (sample CON 0B) was transferred to a $15-\mathrm{mL}$ centrifuge cone; the remaining liquid (sample CON 0A) was transferred to a sample vial and assigned sample number S11T011048. The cone was suspended in a water bath maintained at $18^{\circ} \mathrm{C}$ for 26 days. No physical changes (specifically, no solids formation) were observed. The liquid in the cone was then transferred to a second sample vial and assigned sample number S11T011049. Both vials were loaded out of the 11A hot cells and submitted to 222-S for physicochemical analysis at the conclusion of the boildown study.

Specific gravity $(\mathrm{SpG})$ was one of the analyses requested for the composite sample. The value reported by $222-\mathrm{S}$ is actually a density. The average of duplicate $222-\mathrm{S}$ measurements was $1.243 \pm 0.018 \mathrm{~g} / \mathrm{mL}$. The temperature of the composite when the density was measured was not reported.

\subsection{BOILDOWN APPARATUS}

\subsubsection{Temperature Sensor}

A K-type thermocouple was used to measure the temperature of the test liquid/slurry in the boildown apparatus. The thermocouple signal was converted to a temperature readout $\left(\mathrm{T}_{\text {Read }}\right)$ using a Fisher ${ }^{1}$ Model M107568 thermocouple reader. The $\mathrm{T}_{\text {Read }}$ values were changed to corrected temperatures $\left(\mathrm{T}_{\text {Corrected }}\right.$ ) using a calibration equation comparing the $\mathrm{T}_{\text {Read }}$ with 'true' temperatures measured with a calibrated platinum resistance temperature detector (Pt-RTD) (ebro Electronic, ${ }^{2}$ Model TFX410-1/TPX200, Serial Number 15061117/15059510).

Comparative temperature readings were made as a charge of initially cold reagent water in the

\footnotetext{
${ }^{1}$ Thermo Fisher Scientific Inc., Waltham, Massachusetts.
}

2 ebro Electronic Gmbh \& Co. KG, Ingolstadt. 
boildown pot was slowly heated to boiling and then allowed to cool while being stirred gently. The resulting temperature calibration equation was:

$$
\mathrm{T}_{\text {Corrected }}{ }^{\circ} \mathrm{C}=\left(1.69 \times 10^{-6}\right)\left(\mathrm{T}_{\text {Read }}\right)^{3}-\left(5.59 \times 10^{-4}\right)\left(\mathrm{T}_{\text {Read }}\right)^{2}+(1.03)\left(\mathrm{T}_{\text {Read }}\right)-0.197
$$

\subsubsection{Pressure Sensor/Controller}

The pressure within the boildown apparatus was read from a Cole-Parmer ${ }^{\circledR}$ Instrument Company, ${ }^{3}$ Model 68801-23 pressure reader/controller. A calibration equation was generated to change pressure readings $\left(\mathrm{P}_{\text {Read }}\right)$ from the reader/controller to corrected pressures $\left(\mathrm{P}_{\text {Corrected }}\right)$. First, sets of $\mathrm{T}_{\text {Corrected }}{ }^{\circ} \mathrm{C}$ and $\mathrm{P}_{\text {Read }}$ values were recorded as reagent water was boiled at pressures ranging from 28 to 119 Torr. The $\mathrm{P}_{\text {Read }}$ values were then compared with reference values for the vapor pressure of water at $\mathrm{T}_{\text {Corrected. }}$. The resulting pressure calibration equation was:

$$
\mathrm{P}_{\text {Corrected }} \text { Torr }=(0.9823)\left(\mathrm{P}_{\text {Read }}\right)+1.720
$$

\subsubsection{Boildown Pot}

The glass boildown pot used in this study has a maximum working volume of $500 \mathrm{~mL}$ and a minimum working volume of $\approx 75 \mathrm{~mL}$. The main portion of the pot is a flat-bottomed cylindrical vessel with an inner diameter of $\approx 7.9 \mathrm{~cm}$ and a height of $\approx 9.5 \mathrm{~cm}$. Three vertical, fin-like baffles protruding $\approx 6 \mathrm{~mm}$ into the interior of the pot facilitate mixing of the pot contents when stirred by a magnetic stirbar on the bottom of the pot. The upper portion of the pot is tapered (over $\approx 2.5 \mathrm{~cm}$ ) to a cylindrical throat with an inner diameter of $5 \mathrm{~cm}$. The top surface of the upper throat contains a groove for the O-ring joint by which the pot is connected to the rest of the boildown apparatus. Heating of the pot contents is accomplished by bringing a laboratory hotplate/magnetic stirrer into contact with the bottom of the pot.

\subsubsection{Centrifuge Cones}

All but one of the AP-107 boildown samples submitted for analysis were initially collected in 15-mL, plastic centrifuge cones. The volume scales on the cones were used to estimate the quantities of solids present in the samples and to calculate the bulk densities $\left(\mathrm{D}_{\mathrm{Bulk}}\right)$ of the test samples. These cones are graduated in $0.5-\mathrm{mL}$ increments from 1 to $14.5 \mathrm{~mL}$ and in $0.1-\mathrm{mL}$ increments from 0 to $1 \mathrm{~mL}$. The accuracy of the volume scales was checked by measuring the weight of reagent water required to fill the cones to the 10.0-, 11.5-, and 13.0-mL marks. The reference densities of water at the measurement temperatures were then used to calculate the actual volumes of water added. Triplicate measurements were performed for each cone (additional measurements were completed for Cones 1 and 8). A linear function was derived for each cone relating the volume read from the cone gradations $\left(\mathrm{Vol}_{\text {Read }}\right)$ to the 'actual' volume

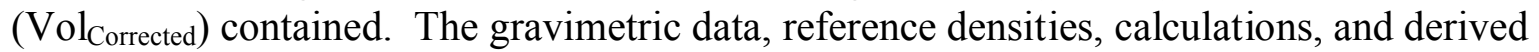
correction functions for each cone/boildown sample are presented in Attachment A.

\footnotetext{
${ }^{3}$ Cole-Parmer ${ }^{\circledR}$ is a registered trademark of Cole-Parmer Instrument Company, Vernon Hills, Illinois.
} 


\subsection{TEST OPERATIONS AND RESULTS}

\subsection{HOT CELL TEST OPERATIONS}

The basic operations performed and observations made during the boildown concentration, dilution, and sample processing stages are summarized in this section. Transcripts of the hot cell data logs that were used to control the boildown operations and perform the first data processing calculations are presented in Attachment B. Photographs of the samples withdrawn from the pot during the boildown are presented in Attachment $\mathrm{C}$.

\subsubsection{Boildown Progress Parameters}

Three parameters are used to monitor the progress of the boildown operations and in postboildown data processing: concentration ratio $(C R), \% \mathrm{WVR}$, and $\mathrm{D}_{\mathrm{Bulk}}$. The $C R$ and \%WVR are defined as

$$
\begin{gathered}
C R=\mathrm{Vol}_{\text {Start }} / \mathrm{Vol}_{\text {End }} \\
\% \mathrm{WVR}=\left[\left(\mathrm{Vol}_{\text {Start }}-\mathrm{Vol}_{\text {End }}\right) / \mathrm{Vol}_{\text {Start }}\right] \times 100
\end{gathered}
$$

The $C R$ is the factor to which nonvolatile, infinitely soluble species become concentrated over their initial concentrations as the solution volume is reduced $(C R>1)$ or increased $(0<C R<1)$.

Accurate measurement of the concentrate volume during a boildown run is very difficult. Even if this were not so, when multiple samples are withdrawn from the pot the concentrate volume during a boildown is no longer the appropriate value of $\mathrm{Vol}_{\mathrm{End}}$ for calculation of $C R$ or $\% \mathrm{WVR}$.

In practice, a boildown test is planned and controlled using an additive volumes model based on the following assumptions: (1) all solutes are nonvolatile (i.e., only water is removed from the test system), (2) the quantities of all additions to or removals from the system are accurately measured, (3) the volumes of all system components are measured at a common temperature, and (4) the volumes of system components are additive (i.e., $\mathrm{Vol}_{\text {Start }}=\mathrm{Vol}_{\text {End }} \pm \mathrm{Vol}_{\mathrm{H} 2 \mathrm{O}}$ ). Using this model, boildown progress is calculated stepwise. For each Step N

$$
\begin{gathered}
\mathrm{Vol}_{\text {Start Step N }}=\mathrm{Vol}_{\text {End Step N-1 }}-\mathrm{Vol}_{\text {Sample N}} \text {, and } \\
C R_{\text {Step N }}=\mathrm{Vol}_{\text {Start Step N }} /\left(\mathrm{Vol}_{\text {Start Step N }} \pm \mathrm{Vol}_{\mathrm{H} 2 \mathrm{O}}\right)
\end{gathered}
$$

The cumulative $C R$ based on the additive volumes model, $C R_{\text {Model, }}$ is

$$
C R_{\text {Model }}=C R_{\text {Step } 1} \times C R_{\text {Step } 2} \times C R_{\text {Step } 3} \times \ldots . . \times C R_{\text {Step N }}
$$

and

$$
\% \mathrm{WVR}_{\text {Model }}=\left[\left(C R_{\text {Model }}-1\right) / C R_{\text {Model }}\right] \times 100
$$

In the additive volumes model, the bulk density of the concentrate, $\mathrm{D}_{\text {Model }}$, is a linear function of CR:

$$
\mathrm{D}_{\text {Model }}=\left[\left(\mathrm{D}_{\mathrm{AP}-107 \text { Composite }}-\mathrm{D}_{\mathrm{H} 2 \mathrm{O}}\right) \times C R_{\text {Model }}\right]+\mathrm{D}_{\mathrm{H} 2 \mathrm{O}}
$$


The density of the AP-107 test composite was measured in the 11A-6 hot cell (Table 2-2) and found to be $1.216 \mathrm{~g} / \mathrm{mL}$ at $26.8^{\circ} \mathrm{C}$. This value was used to convert the starting weight of the test composite to a volume. The weights of water removed/added during the boildown were converted to volumes by dividing by the reference density of water at $26.8^{\circ} \mathrm{C}$. The weights of samples removed from the pot were converted to volumes by dividing by the $\mathrm{D}_{\text {Model }} 26.8^{\circ} \mathrm{C}$ values

calculated in the spreadsheet log. The resulting values of $C R_{\text {Model }}{ }^{26.8^{\circ} \mathrm{C}}$ and $\% \mathrm{WVR}_{\text {Model }}{ }^{26.8^{\circ} \mathrm{C}}$ are shown in the boildown log in Table B-1.

\subsubsection{Boildown Test Log}

The following is a chronological log of the AP-107 boildown study, annotated with key observations and descriptions. Where pressures are cited only as integral values, they refer to the nominal target reflux pressures of 40,60 , or 80 Torr, not actual $\mathrm{P}_{\text {Read }}$ or $\mathrm{P}_{\text {Corrected }}$ values.

The boildown concentration and dilution steps were performed in the 222-S 11A-6 hot cell; sample processing was performed in the adjacent 11A-5 hot cell. Typical ambient temperatures in the hot cells were $\approx 27^{\circ} \mathrm{C}$.

All test samples (with the exception of Composite Sample 0A) were collected in disposable plastic 15-mL centrifuge cones (Section 2.2.4) and processed in these cones through the final separation into centrifuged liquid (C-Liq) and centrifuged solids (C-Slds) fractions.

\section{Boildown Composite Preparation-September 22, 2011}

13:00 The AP-107 boildown test composite was prepared using 6 of the 7 grab samples received at the 222-S Laboratory (Section 2.1). No appreciable solids were observed in any of the grab samples, and the final composite was a yellow liquid that had a very slight cloudiness but contained no visible solids.

A sample was withdrawn from the composite for analysis. Sample CON 0A was transferred to a labeled sample vial and set aside. Sample CON OB was transferred to a 15-mL centrifuge cone and set aside.

\section{Boildown Volume Reduction Sequence-October 3, 2011}

08:30 A 578.170-g portion of AP-107 composite was transferred to the boildown pot. The density of the composite was measured during the transfer (Section 2.1) and determined to be $1.216 \mathrm{~g} / \mathrm{mL}$ at $26.8^{\circ} \mathrm{C}$. The calculated initial volume of the composite test sample was $475.473 \mathrm{~mL}$.

09:25 Boiling pressure/temperature $(\mathrm{P} / \mathrm{T})$ measurements on the unconcentrated composite were completed at 40, 60, and 80 Torr. Boiling was gentle and well behaved; no foaming was observed. The test composite was a clear yellow liquid with no solids.

10:00 Concentration at 40 Torr was begun (CON 1a). On completion at 10:54, $45.3 \mathrm{~mL}$ of water was removed: $9.54 \% \mathrm{WVR}_{\text {Model }} 26.8^{\circ} \mathrm{C}$. At $11: 13, \mathrm{P} / \mathrm{T}$ measurements at 40,60 , and 80 Torr were completed. Boiling was gentle and well behaved with no foaming. Composite was a clear, medium yellow liquid with no visible solids. 
11:17 Concentration at 40 Torr was begun (CON 1b). On completion at 12:00, $46.2 \mathrm{~mL}$ of water was removed: $19.26 \% \mathrm{WVR}_{\text {Model }}{ }^{26.8^{\circ} \mathrm{C}}$. At 12:18, $\mathrm{P} / \mathrm{T}$ measurements at 40,60 , and 80 Torr were completed. Boiling was gentle and well behaved with no foaming. Composite was a clear, medium yellow liquid with no visible solids.

12:22 Concentration at 40 Torr was begun (CON-1c). On completion at 13:02, $44.0 \mathrm{~mL}$ of water was removed: $28.52 \% \mathrm{WVR}_{\text {Model }} 26.8^{\circ} \mathrm{C}$. At 13:21, P/T measurements at 40,60, and 80 Torr were completed. Boiling was gentle and well behaved with no foaming. Composite was a clear, medium-yellow liquid with no visible solids (Figure 3-1a).

13:40 Sample CON 1 was drawn from the pot and transferred to centrifuge Cone 2. A photograph of the sample was taken after the pot was reconnected to the still head.

13:50 Boildown was halted overnight. The heat to the boildown pot was turned off and the pot was vented to hot cell ambient pressure. Magnetic stirrer was left on.

\section{Boildown Volume Reduction Sequence-October 4, 2011}

06:30 Overnight at hot cell ambient pressure and temperature $\left(25.6^{\circ} \mathrm{C}\right)$, the test composite became cloudy and was completely opaque.

07:30 Composite reflux established at 40 Torr $\left(38.0^{\circ} \mathrm{C}\right)$. Boiling was well behaved with no foaming and no visible change in solids loading.

07:45 Composite reflux established at 60 Torr $\left(46.0^{\circ} \mathrm{C}\right)$. Boiling was well behaved with no foaming and no visible change in solids loading.

07:55 Composite reflux established at 80 Torr $\left(52.0^{\circ} \mathrm{C}\right)$. Boiling was well behaved with no foaming and no visible change in solids loading.

07:58 Concentration at 80 Torr was begun (CON 2). On completion at 08:38, $42.7 \mathrm{~mL}$ of water was removed: $37.82 \% \mathrm{WVR}_{\text {Model }} 26.8^{\circ} \mathrm{C}$. At 08:48, $\mathrm{P} / \mathrm{T}$ measurements at 40,60, and 80 Torr were completed. Boiling was gentle and well behaved with no foaming and no visible change in appearance of the solids (Figure 3-1b).

09:10 Sample CON 2 was drawn from the pot and transferred to centrifuge Cone 3. A photograph of the sample was taken after the pot was reconnected to the still head.

09:30 Concentration at 40 Torr was begun (CON 3). On completion at 09:50, $21.5 \mathrm{~mL}$ of water was removed: $42.73 \% \mathrm{WVR}_{\text {Model }} 26.8^{\circ} \mathrm{C}$. At 10:07, $\mathrm{P} / \mathrm{T}$ measurements at 40,60 , and 80 Torr were completed. Boiling was gentle and well behaved with no appreciable foaming, and no visible change in appearance of the solids.

10:30 Sample CON 3 was drawn from the pot and transferred to centrifuge Cone 4. A photograph of the sample was taken after the pot was reconnected to the still head.

10:45 Concentration at 80 Torr was begun (CON 4). On completion at 11:12, $18.8 \mathrm{~mL}$ of water was removed: $47.22 \% \mathrm{WVR}_{\text {Model }} 26.8^{\circ} \mathrm{C}$. At 11:28, P/T measurements at 40,60, and 80 Torr were completed. Boiling was gentle and well behaved with no foaming and no appreciable change in appearance of the solids. 
Figure 3-1. Appearance of the Composite During Boildown Test.

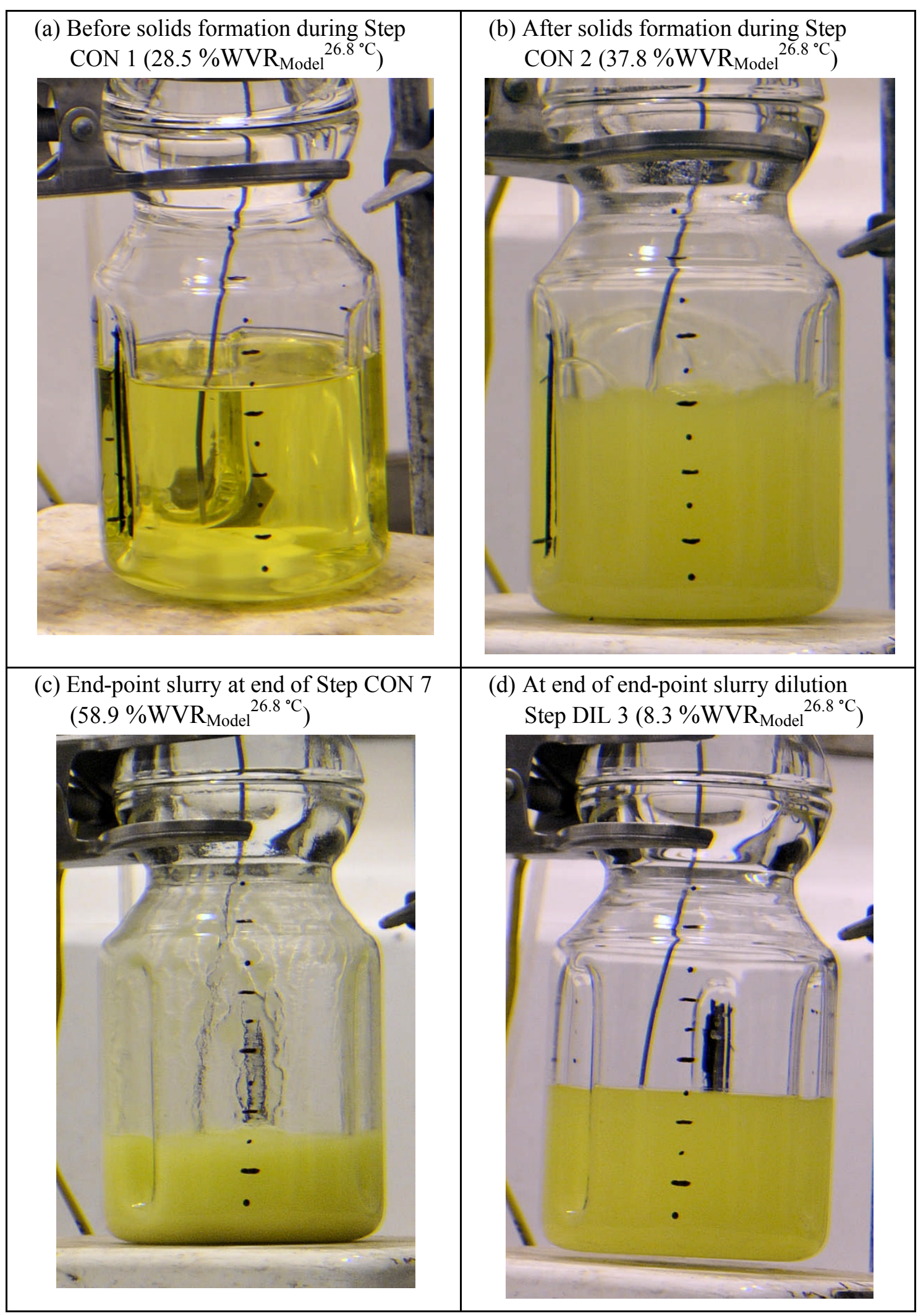


11:36 Sample CON 4 was drawn from the pot and transferred to centrifuge Cone 5. A photograph of the sample was taken after the pot was reconnected to the still head.

11:50 Concentration at 40 Torr was begun (CON 5). On completion at 12:12, $16.7 \mathrm{~mL}$ of water was removed: $51.45 \% \mathrm{WVR}_{\text {Model }} 26.8^{\circ} \mathrm{C}$. At 12:23, P/T measurements at 40, 60, and 80 Torr were completed. Boiling was well behaved with minor foaming (a single layer of $\approx 1 \mathrm{~cm}$ bubbles) and no appreciable change in appearance of the solids.

12:35 Sample CON 5 was drawn from the pot and transferred to centrifuge Cone 6. A photograph of the sample was taken after the pot was reconnected to the still head.

13:00 Concentration at 80 Torr was begun (CON 6). On completion at 13:35, 15.1 mL of water was removed: $55.53 \% \mathrm{WVR}_{\text {Model }} 26.8^{\circ} \mathrm{C}$. At 13:44, $\mathrm{P} / \mathrm{T}$ measurements at 40,60 , and 80 Torr were completed. Boiling was bumpy with moderate foaming (a single layer of $\approx 1 \mathrm{~cm}$ bubbles). The loading of fine, white solids in the slurry was noticeably greater.

14:02 Sample CON 6 was drawn from the pot and transferred to centrifuge Cone 7. A photograph of the sample was taken after the pot was reconnected to the still head.

14:18 Concentration at 40 Torr was begun (CON 7). On completion at 14:36, $11.6 \mathrm{~mL}$ of water was removed: $58.92 \% \mathrm{WVR}_{\text {Model }}{ }^{26.8^{\circ} \mathrm{C}}$. At 14:47, $\mathrm{P} / \mathrm{T}$ measurements at 40,60 , and 80 Torr were completed. This was the end-point of the boildown concentration. The test composite was a viscous slurry of fine, white solids in a yellow liquid (Figure 3-1c).

15:00 Sample CON 7 was drawn from the pot and transferred to centrifuge Cone 8. A photograph of the sample was taken after the pot was reconnected to the still head.

\section{End-point Slurry Dilution Sequence-October 4, 2011}

15:34 Dilution Step DIL 1 was completed by adding $120.5 \mathrm{~mL}$ of water back to the pot: $20.31 \% \mathrm{WVR}_{\text {Model }} 26.8^{\circ} \mathrm{C}$. Reflux of the test slurry at 60 Torr was established, and a P/T measurement was completed at 16:00. Boiling was well behaved with no foaming. The concentration of solids was visibly reduced but the test slurry remained opaque (high contrast markings on the opposite wall of the pot were not visible).

16:12 Sample DIL 1 was drawn from the pot and transferred to centrifuge Cone 9. A photograph of the sample was taken after the pot was reconnected to the still head.

16:40 Dilution Step DIL 2 was completed by adding $16.3 \mathrm{~mL}$ of water back to the pot: $14.81 \% \mathrm{WVR}_{\text {Model }} 26.8^{\circ} \mathrm{C}$. Reflux of the test slurry at 60 Torr was established, and a $\mathrm{P} / \mathrm{T}$ measurement was completed at 16:59. Boiling was well behaved with no foaming. The concentration of solids was visibly reduced but the test slurry remained opaque.

17:07 Sample DIL 2 was drawn from the pot and transferred to centrifuge Cone 10. A photograph of the sample was taken after the pot was reconnected to the still head.

17:37 Dilution Step DIL 3 was completed by adding $18.2 \mathrm{~mL}$ of water back to the pot: $8.33 \% \mathrm{WVR}_{\text {Model }} 26.8^{\circ} \mathrm{C}$. Reflux of the test slurry at 60 Torr was established and a P/T measurement was completed at 17:54. Boiling was well behaved with no foaming. The test slurry was no longer completely opaque but was still very cloudy (Figure 3-1d).

18:05 Sample DIL 3 was drawn from the pot and transferred to centrifuge Cone 11. A photograph of the sample was taken after the pot was reconnected to the still head. 
LAB-RPT-12-00008, R0

18:12 Heat to the boiling pot was turned off and the pot was vented to ambient hot cell pressure. Stirring of the pot contents was continued overnight.

\section{Boildown Completion-October 5, 2011}

07:00 Appearance of the test slurry in the boildown pot did not change significantly after cooling to ambient temperature overnight. The weight of the remaining slurry was $293.97 \mathrm{~g}$. The final slurry was transferred to a jar for temporary storage.

\subsection{HOT CELL SAMPLE PROCESSING}

\subsubsection{Initial Sample Processing}

October 5, 2011: By mid-morning, composite Sample CON 0B had sat at hot cell composite temperatures for $168 \mathrm{hrs}$, Sample CON 1 for $45 \mathrm{hrs}$, and Samples CON 2-7 and DIL 1-3 for 18-26 hrs. All 11 cones were weighed and photographed (Attachment C). The total sample volume and the estimated volume of any settled solids (S-Slds) were recorded for each sample.

All 11 sample cones and the jar containing the final slurry recovered from the boildown pot were transferred to hot cell $11 \mathrm{~A}-5$ and suspended in a water bath cooled to $18{ }^{\circ} \mathrm{C}$.

October 11, 2011: Starting at 12:40, each sample cone was removed from the water bath, photographed, and then returned to the $18{ }^{\circ} \mathrm{C}$ water bath.

October 12, 2011: Starting at 07:00, each boildown sample was removed from the $18{ }^{\circ} \mathrm{C}$ water bath and photographed. The total sample volume, S-Slds volume, and visual appearance of the S-Slds were recorded for each sample. The samples were then returned to the water bath.

The appearance and settling behavior observed in boildown Samples CON 1-10 are summarized in Table 3-1. Descriptions of the samples shortly after removal from the pot, after at least $18 \mathrm{hrs}$ at hot cell ambient temperature, and after $\approx 7$ days at $18{ }^{\circ} \mathrm{C}$ are included. Photographs of the sample cones at approximately the same times are presented in Attachment $\mathrm{C}$.

\subsubsection{Final Sample Processing}

October 12, 2011: Starting at 13:45, the boildown samples were removed from the $18{ }^{\circ} \mathrm{C}$ water bath, in pairs, and centrifuged for $5-6$ minutes at $\approx 1000 \times g$. The samples were then returned to the water bath.

No solids were observed in Sample CON 0B, the subsample of the initial composite liquid. The sample liquid was transferred to a labeled sample vial and set aside for laboratory analysis. 
Table 3-1. Appearance of Settled Solids in Boildown Samples. (2 sheets)

\begin{tabular}{|c|c|}
\hline Sample & \\
\hline CON 1 & $\begin{array}{l}<\mathbf{1 ~ h r} \text { after sampling: The pot sample was a clear, yellow liquid with no solids visible. } \\
\mathbf{4 5} \mathrm{hrs} \text { at at } 26.2-25.1^{\circ} \mathrm{C} \text { : Very fine-grained, white/colorless solids formed as the sample cooled to hot } \\
\text { cell ambient temperature. After } 45 \mathrm{hrs} \text {, the supernatant was clear and S-Slds filled the } \approx 0.4 \mathrm{~mL} \text { bottom } \\
\text { of the cone. } \\
7 \text { days at } 18{ }^{\circ} \mathrm{C}: \approx 0.6 \mathrm{~mL} \text { of fine grained white/colorless S-Slds filled the bottom of the cone. } \\
\text { Particles in the S-Slds were too small to observe any morphology. }\end{array}$ \\
\hline CON 2 & $\begin{array}{l}\mathbf{1} \text { hr after sampling: The pot sample contained white/colorless solids in very small flocs dispersed } \\
\text { throughout the sample volume. The solids settled fairly quickly. } \\
\mathbf{2 6} \text { hrs at } \mathbf{2 5 . 9 - 2 5 . 1}{ }^{\circ} \mathbf{C} \text { : The supernatant and cone walls were clear. Very fine-grained, white/colorless } \\
\text { solids filled the bottom } \approx 1.5 \mathrm{~mL} \text { of the cone. Particles in the S-Slds were too small to observe any } \\
\text { morphology. } \\
\mathbf{7} \text { days at } 18^{\circ} \mathrm{C}: \text { No significant change in the appearance of the S-Slds. }\end{array}$ \\
\hline CON 3 & $\begin{array}{l}<\mathbf{1} \text { hr after sampling: The pot sample was similar to Sample CON } 2 \text { in appearance and settling rate. } \\
\mathbf{2 5} \text { hrs at } \mathbf{2 6 . 0 - 2 5 . 2}{ }^{\circ} \mathbf{C}: \text { The supernatant and cone walls were clear. Very fine-grained, white/colorless } \\
\text { S-Slds filled the bottom } \approx 1.6 \mathrm{~mL} \text { of the cone. } \\
7 \text { days at } 18^{\circ} \mathrm{C}: \text { No significant change in the appearance of the S-Slds. Particles in the S-Slds were } \\
\text { too small to observe any morphology. }\end{array}$ \\
\hline $\mathrm{CON} 4$ & $\begin{array}{l}<\mathbf{1} \text { hr after sampling: The pot sample was similar to Samples CON } 2 \text { and CON } 3 \text { in appearance and } \\
\text { settling rate. } \\
\mathbf{2 4} \text { hrs at } \mathbf{2 5 . 9 - 2 5 . 2}{ }^{\circ} \mathbf{C} \text { : The supernatant and cone walls were clear. Very fine-grained, white/colorless } \\
\text { solids filled the bottom } \approx 1.4 \mathrm{~mL} \text { of the cone. } \\
7 \text { days at } 18{ }^{\circ} \mathbf{C}: \text { No significant change in the appearance of the S-Slds. Particles in the S-Slds were } \\
\text { too small to observe any morphology. }\end{array}$ \\
\hline CON 5 & $\begin{array}{l}<\mathbf{1} \text { hr after sampling: The pot sample was very similar to Samples CON 2-4 in appearance. The } \\
\text { solids settled very quickly. } \\
\mathbf{2 3} \text { hrs at } 25.9-25.2^{\circ} \mathrm{C}: \text { The supernatant and cone walls were clear. Very fine-grained, white/colorless } \\
\text { solids filled the bottom } \approx 1.7 \mathrm{~mL} \text { of the cone. } \\
7 \text { days at } 18^{\circ} \mathrm{C}: \text { No significant change in the appearance of the S-Slds. Particles in the S-Slds were } \\
\text { too small to observe any morphology. }\end{array}$ \\
\hline CON 6 & $\begin{array}{l}<\mathbf{1} \text { hr after sampling: The pot sample was similar to Samples CON 2-5 in appearance and settling } \\
\text { rate. } \\
\mathbf{2 1} \text { hrs at } 26.2-25.2^{\circ} \mathrm{C} \text { : The supernatant and cone walls were clear. Very fine-grained, white/colorless } \\
\text { solids filled the bottom } \approx 2.0 \mathrm{~mL} \text { of the cone. } \\
7 \text { days at } 18^{\circ} \mathrm{C} \text { : No significant change in the appearance of the S-Slds. Particles in the S-Slds were } \\
\text { too small to observe any morphology. }\end{array}$ \\
\hline CON 7 & $\begin{array}{l}<\mathbf{1} \text { hr after sampling: This was the end-point slurry sample. The slurry had a high concentration of } \\
\text { very fine-grained, white/colorless, crystalline solids in a yellow liquid. } \\
\mathbf{2 1} \text { hrs at } \mathbf{2 6 . 0 - 2 5 . 2}{ }^{\circ} \mathbf{C} \text { : Settling of the solids was severly hindered, and after } 21 \mathrm{hrs} \text { the S-Slds still } \\
\text { occupied } \approx 89 \% \text { of the sample volume. } \\
\mathbf{7} \text { days at } \mathbf{1 8}{ }^{\circ} \mathbf{C} \text { : The S-Slds compacted slowly to a mass occupying } \approx 76 \% \text { of the sample volume. } \\
\text { There was no significant change in appearance of the S-Slds. Particles in the S-Slds were too small to } \\
\text { observe any morphology. }\end{array}$ \\
\hline
\end{tabular}


Table 3-1. Appearance of Settled Solids in Boildown Samples. (2 sheets)

\begin{tabular}{|c|c|}
\hline Sample & Appearance of Settled Solids \\
\hline DIL 1 & $\begin{array}{l}<\mathbf{1} \text { hr after sampling: The pot sample contained white/colorless solids in a mixture of fine-grained } \\
\text { particulates and small flocs. The particulates settled out within a few minutes leaving a very disperse } \\
\text { suspension of the small flocs in suspension. } \\
\mathbf{1 9} \text { hrs at } \mathbf{2 6 . 2 - 2 5 . 2}{ }^{\circ} \mathbf{C}: \text { The supernatant and cone walls were clear. Fine-grained white/colorless solids } \\
\text { filled } \approx 0.4 \mathrm{~mL} \text { of the bottom of the cone. } \\
\mathbf{7} \text { days at } 18^{\circ} \mathrm{C}: \text { There was no significant change in the appearance of the S-Slds. Particles in the } \\
\text { S-Slds were too small to observe any morphology. }\end{array}$ \\
\hline DIL 2 & $\begin{array}{l}\mathbf{1} \text { hr after sampling: The pot sample was similar to Sample DIL } 1 \text { in appearance and settling rate. } \\
\mathbf{1 9} \text { hrs at } \mathbf{2 6 . 1 - 2 5 . 2}{ }^{\circ} \mathbf{C} \text { : The supernatant and cone walls were clear. Fine-grained, white/colorless } \\
\text { S-Slds filled the bottom } \approx 0.3 \mathrm{~mL} \text { of the cone. } \\
7 \text { days at } 18^{\circ} \mathbf{C} \text { : There was no significant change in the appearance of the S-Slds. Particles in the } \\
\text { S-Slds were too small to observe any morphology. }\end{array}$ \\
\hline DIL 3 & $\begin{array}{l}<\mathbf{1} \mathbf{~ h r} \text { after sampling: The pot sample was similar to Samples DIL } 1 \text { and DIL } 2 \text { in appearance and } \\
\text { settling rate. } \\
\mathbf{1 8} \text { hrs at } \mathbf{2 6 . 0 - 2 5 . 3}{ }^{\circ} \mathrm{C} \text { : The supernatant and cone walls were clear. Fine-grained, white/colorless } \\
\text { S-Slds filled the bottom } \approx 0.2 \mathrm{~mL} \text { of the cone. } \\
7 \text { days at } 18^{\circ} \mathrm{C} \text { : No significant change in the appearance of the S-Slds. Particles in the S-Slds were } \\
\text { too small to observe any morphology. }\end{array}$ \\
\hline
\end{tabular}

October 13, 2011: Starting at 06:50, boildown Samples CON 1-7 and DIL 1-3 were removed from the $18{ }^{\circ} \mathrm{C}$ water bath, in pairs, centrifuged for 5-6 minutes at $\approx 1000 \times g$, and then returned to the bath. After all 10 samples had been through the second centrifuge cycle, they were photographed.

The following processing sequence was then followed for each sample. A sample cone was removed from the $18{ }^{\circ} \mathrm{C}$ water bath and centrifuged for a third period of 5-6 minutes at $\approx 1000 \times g$. The apparent volumes of the total sample and of the $\mathrm{C}$-Slds were recorded. The $\mathrm{C}$-Liq was then decanted into a labeled sample vial. The wet C-Slds were then centrifuged for a final period of 5-6 minutes and any additional C-Liq was decanted to the sample vial. The final $\mathrm{C}$-Liq and C-Slds weights were measured and recorded. The sample vials containing the C-Liq samples were set aside. The centrifuge cones and damp C-Slds were returned to the $18{ }^{\circ} \mathrm{C}$ water bath.

October 17, 2011: Starting at 08:15, samples of the C-Slds from the boildown samples were collected for solid phase characterization (SPC).

Due to the small quantities of C-Slds present, the solids recovered from Samples CON 1-CON 3 were combined. A small quantity of C-Liq from Sample CON 3 was used to facilitate recovery and transfer of the C-Slds to a sample vial. 
Due to the small quantities of C-Slds present, the solids recovered from Samples CON 4 and CON 5 were also combined. A small quantity of C-Liq from Sample CON 5 was used to facilitate recovery and transfer of the C-Slds to a sample vial.

All the C-Slds from Sample CON 6 were recovered using a small volume of Sample CON 6 C-Liq and transferred to a sample vial.

A portion $(\approx 4.5 \mathrm{~g})$ of the C-Slds from the end-point slurry, Sample CON 7, was transferred to a labeled sample vial.

The C-Slds from Sample DIL 3 were transferred to a sample vial. Most of the S-Slds that had settled to the bottom of the jar containing the final slurry set aside at the conclusion of the boildown test were also recovered and combined with the DIL 3 C-Slds.

The final identifications of the AP-107 boildown study samples are tabulated in Table 3-2.

Table 3-2. Identification of Boildown Samples.

\begin{tabular}{|c|c|c|}
\hline \multirow[b]{2}{*}{ Test Sample } & \multicolumn{2}{|c|}{ 222-S Sample Number S11T0- } \\
\hline & Liquid & Solids \\
\hline \multicolumn{3}{|c|}{ Test Composite } \\
\hline \multirow[t]{2}{*}{ CON 0} & -11048 & \multirow[t]{2}{*}{-} \\
\hline & -11049 & \\
\hline \multicolumn{3}{|c|}{ Volume Reduction } \\
\hline CON 1 & -11062 & \multirow[t]{3}{*}{-14140} \\
\hline CON 2 & -11063 & \\
\hline CON 3 & -11064 & \\
\hline $\mathrm{CON} 4$ & -11065 & \multirow[t]{2}{*}{-14141} \\
\hline CON 5 & -11066 & \\
\hline CON 6 & -11067 & -14280 \\
\hline $\mathrm{CON} 7$ & -11070 & -11074 \\
\hline \multicolumn{3}{|c|}{ Dilution of End-point Slurry } \\
\hline DIL 1 & -11071 & - \\
\hline DIL 2 & -11072 & - \\
\hline DIL 3 & -11073 & -11075 \\
\hline
\end{tabular}

October 18, 2011: At 11:00, the 12 samples of boildown liquids (including composite Sample CON 0A that was transferred directly to a sample vial) were loaded out of the 11A hot cells and submitted to 222-S for analysis. The 5 samples of boildown sample solids were loaded out and submitted for SPC measurements. 


\subsubsection{Densities of Boildown Sample Liquids}

The densities of the boildown C-Liq samples were measured before the samples were loaded out of the hot cells and submitted to 222-S for analysis. The measurements were performed as follows: The temperature of the C-Liq sample was measured (the temperatures of the samples ranged from $25.3-25.5^{\circ} \mathrm{C}$ ). Using a positive-displacement pipette, a 1-mL portion of liquid was transferred to a sample vial and weighed. A second 1-mL sample portion was then added to the vial and its weight was determined. The average C-Liq density was calculated. The 2-mL portion of C-Liq was returned to the parent sample using a disposable pipette.

The density of demineralized water was measured several times before and after the C-Liq sample measurements. All the measured densities were within $1 \%$ of the reference values for pure water.

\subsection{FINAL VOLUME AND WEIGHT DATA}

The results of gravimetric and volumetric measurements on the boildown samples are summarized in Table 3-3.

The total, S-Slds and C-Slds volumes at hot cell ambient temperature $\left(25.1-25.3{ }^{\circ} \mathrm{C}\right)$ and at $18{ }^{\circ} \mathrm{C}$ are based on examination of sample photographs. Apparent volumes ( $\left.\mathrm{Vol}_{\text {Read }}\right)$ were measured as

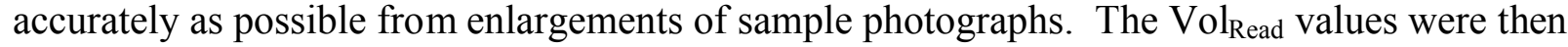
converted to $\mathrm{Vol}_{\text {Corrected }}$ total volumes using the cone calibration functions in Attachment A. The total volumes of the samples at $18{ }^{\circ} \mathrm{C}$ are believed to be the most accurately measured values.

The vol\% S-Slds and vol\% C-Slds in each sample are the apparent volumes of the solids divided by the corrected total volumes at $18{ }^{\circ} \mathrm{C}$ or hot cell ambient temperature with the results multiplied by 100 .

The $\mathrm{D}_{\text {Bulk }}$ values are the weights of the bulk samples (i.e., combined liquid and solids) divided by the total sample volumes measured at the indicated temperature.

The $\mathrm{D}_{\text {Liq }}$ values in Table 3-3 tabulate the results of measurements of the densities of the C-Liq portions of the boildown samples. Each $\mathrm{D}_{\mathrm{Liq}}{ }^{18^{\circ} \mathrm{C}}$ value is the weight of C-Liq decanted from a sample divided by the estimated difference between the total and C-Slds volumes while still in the $15-\mathrm{mL}$ centrifuge cone at $18^{\circ} \mathrm{C}$. 
Table 3-3. Gravimetric and Volumetric Data for Boildown Samples.

\begin{tabular}{|c|c|c|c|c|c|c|c|c|c|c|c|}
\hline Test Sample & CON OB & CON 1 & CON 2 & CON 3 & $\operatorname{CON} 4$ & CON 5 & CON 6 & CON 7 & DIL 1 & DIL 2 & DIL 3 \\
\hline$\% \mathrm{WVR}^{18^{\circ} \mathrm{C} \text { a }}$ & 0.00 & 27.74 & 36.88 & 41.58 & 46.05 & 50.15 & 54.04 & 57.47 & 19.90 & 14.66 & 8.37 \\
\hline$C R^{18^{\circ} \mathrm{C} \text { a }}$ & 1.000 & 1.384 & 1.584 & 1.712 & 1.854 & 2.006 & 2.176 & 2.352 & 1.248 & 1.172 & 1.091 \\
\hline Total Wt (g) & 14.674 & 15.820 & 17.340 & 15.949 & 16.600 & 17.600 & 17.759 & 19.869 & 16.323 & 16.409 & 15.864 \\
\hline Wt Wet $18^{\circ} \mathrm{C}$ C-Slds (g) & 0.000 & 0.301 & 0.603 & 0.730 & 0.956 & 1.096 & 1.745 & 7.699 & 0.192 & 0.147 & 0.090 \\
\hline Wt $18^{\circ} \mathrm{C}$ C-Liq (g) & 14.674 & 15.519 & 16.737 & 15.219 & 15.644 & 16.504 & 16.014 & 12.170 & 16.131 & 16.262 & 15.774 \\
\hline Total Vol ${ }^{\text {Ambient }}(\mathrm{mL})$ & 11.98 & 12.26 & 13.01 & 11.79 & 11.99 & 12.42 & 12.26 & 13.41 & 12.85 & 13.12 & 12.80 \\
\hline $\mathrm{Vol}^{\text {Ambient }}$ S-Slds (mL) & 0.00 & 0.35 & 1.50 & 1.60 & 1.40 & 1.70 & 2.00 & 11.75 & 0.40 & 0.30 & 0.20 \\
\hline Total $\mathrm{Vol}^{18^{\circ} \mathrm{C}}(\mathrm{mL})$ & 12.02 & 12.22 & 13.00 & 11.74 & 11.97 & 12.43 & 12.27 & 13.39 & 12.85 & 13.06 & 12.78 \\
\hline $\mathrm{Vol}^{18^{\circ} \mathrm{C}} \mathrm{S}$-Slds $(\mathrm{mL})$ & 0.00 & 0.55 & 1.40 & 1.45 & 1.25 & 1.50 & 1.90 & 10.20 & 0.40 & 0.35 & 0.20 \\
\hline $\mathrm{Vol}^{1{ }^{\circ} \mathrm{C}} \mathrm{C}$-Slds $(\mathrm{mL})$ & 0.00 & 0.25 & 0.35 & 0.45 & 0.60 & 0.70 & 0.85 & 4.90 & 0.15 & 0.10 & 0.07 \\
\hline $\mathrm{Vol}^{18^{\circ} \mathrm{C}} \mathrm{C}$-Liq $(\mathrm{mL})$ & 12.02 & 11.97 & 12.64 & 11.30 & 11.37 & 11.73 & 11.42 & 8.49 & 12.70 & 12.96 & 12.71 \\
\hline Vol\% S-Slds at Ambient T & 0.0 & 2.9 & 11.5 & 13.6 & 11.7 & 13.7 & 16.3 & 87.60 & 3.1 & 2.3 & 1.6 \\
\hline Vol\% S-Slds at $18{ }^{\circ} \mathrm{C}$ & 0.0 & 4.5 & 10.8 & 12.3 & 10.4 & 12.1 & 15.5 & 76.20 & 3.1 & 2.7 & 1.6 \\
\hline Vol $\%$ C-Slds at $18{ }^{\circ} \mathrm{C}$ & 0.0 & 2.0 & 2.7 & 3.8 & 5.0 & 5.6 & 6.9 & 36.6 & 1.2 & 0.8 & 0.5 \\
\hline $\mathrm{Wt} \%$ Wet $18^{\circ} \mathrm{C} \mathrm{C}$-Slds & 0.00 & 1.90 & 3.48 & 4.58 & 5.76 & 6.227 & 9.826 & 38.749 & 1.18 & 0.90 & 0.57 \\
\hline $\mathrm{D}_{\text {Bulk }}{ }^{18^{\circ} \mathrm{C}}(\mathrm{g} / \mathrm{mL})$ & 1.220 & 1.294 & 1.334 & 1.358 & 1.387 & 1.416 & 1.447 & 1.484 & 1.270 & 1.257 & 1.241 \\
\hline $\mathrm{D}_{\mathrm{Liq}}{ }^{18^{\circ} \mathrm{C}}(\mathrm{g} / \mathrm{mL})$ & 1.220 & 1.296 & 1.324 & 1.347 & 1.376 & 1.407 & 1.402 & 1.434 & 1.270 & 1.255 & 1.241 \\
\hline $\mathrm{D}_{\mathrm{Liq}}{ }^{25.3^{\circ} \mathrm{C}}(\mathrm{g} / \mathrm{mL})$ & 1.226 & 1.302 & 1.339 & 1.356 & 1.396 & 1.407 & 1.422 & 1.422 & 1.264 & 1.248 & 1.236 \\
\hline $\mathrm{D}_{\mathrm{Liq}}^{222-\mathrm{s}}(\mathrm{g} / \mathrm{mL})$ & 1.243 & 1.319 & 1.386 & 1.313 & 1.332 & 1.317 & 1.381 & 1.342 & 1.292 & 1.299 & 1.259 \\
\hline
\end{tabular}

$\mathrm{T}=$ temperature

${ }^{\mathrm{a}}$ Actual test values of boildown progress parameters as calculated in Section 5.1.2. 
The $\mathrm{D}_{\mathrm{Liq}}{ }^{25.3^{\circ} \mathrm{C}}$ values are the results of the density measurements performed using a 1-mL positive displacement pipette before the C-Liq samples were loaded out of the 222-S hot cells (Section 3.2.3).

The $\mathrm{D}_{\mathrm{Liq}}{ }^{222-\mathrm{S}}$ values are the densities of the C-Liq samples measured by 222-S Laboratory personnel. (The $\mathrm{D}_{\mathrm{Liq}}{ }^{222-\mathrm{S}}$ values were reported as specific gravities or $\mathrm{SpG}$; the measurement temperature(s) are not known).

The three sets of liquid density data are presented graphically in Figure 3-2. In this figure and all other plots in this report, values for the initial test composite (CON 0$)$ and the volume reduction sequence samples (CON 1 to CON 7) are displayed with solid data markers; values for the dilution sequence samples (DIL 1 to DIL 3) are displayed with hollow data markers of the same shape and border color.

The plots of the $\mathrm{D}_{\mathrm{Liq}}{ }^{10^{\circ} \mathrm{C}}$ and $\mathrm{D}_{\mathrm{Liq}}{ }^{25.3^{\circ} \mathrm{C}}$ values both display similar trends. The measured densities at $25.3{ }^{\circ} \mathrm{C}$ are greater than those at $18{ }^{\circ} \mathrm{C}$. Since this relationship should be reversed, this indicates that there is some bias in one or both of these data sets. The scatter in the $\mathrm{D}_{\mathrm{Liq}}{ }^{222-\mathrm{S}}$ values is problematic.

Figure 3-2. Density of Sample Liquids versus Boildown Progress.

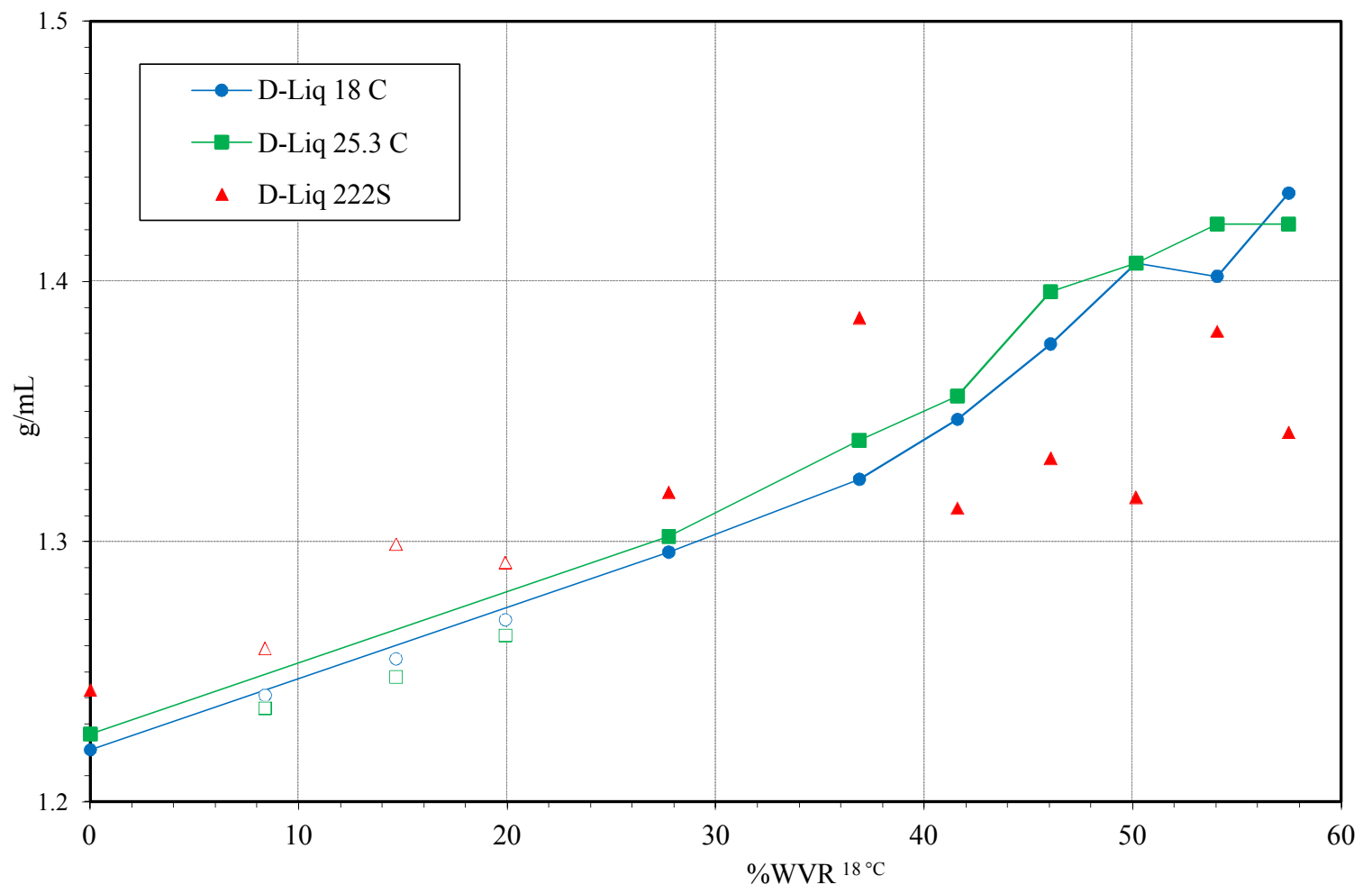




\subsection{LABORATORY ANALYSIS OF BOILDOWN SAMPLES}

The liquid samples retrieved during the AP-107 boildown or created during the subsequent sample processing were submitted to $222-\mathrm{S}$ for chemical analysis. These analyses were performed by the 222-S analytical contractor, Advanced Technologies and Laboratories International, Inc. (ATL). A transcript of the analysis results is presented in Attachment D.

The analysis results are summarized in Table 4-1. Analysis results for all priority analytes are presented. Other (opportunistic) analytes for which none of the analysis results exceeded the reported detection limit have been omitted from the table.

A few anomalies are observed in the analytical data in Table 4-1.

The sum of the total organic carbon (TOC) and total inorganic carbon (TIC) analysis results is equal to the total carbon (Total C) result for the composite sample (Sample CON 0). However, $\mathrm{TOC}+\mathrm{TIC}$ for the end-point liquid (Sample CON 7) is only $\approx 60 \%$ of the Total C result; TOC + TIC for the final dilution liquid (Sample DIL 3 ) is $\approx 85 \%$ of the Total C value. The cause(s) for this discrepancy is unknown.

The concentrations of four organic acid anions - formate, acetate, glycolate, and oxalate - in the sample liquids were analyzed by ion chromatography (IC). The concentrations of organic carbon represented by the reported concentrations of the anions were calculated and subtracted from the reported TOC values measured by acid sparging/persulfate oxidation/coulometry. The differences are tabulated as $\triangle \mathrm{TOC}$. For Samples CON 0, CON 1-7, and DIL 1-2, the reported TOC is $43-71 \%$ greater than the sum of the carbon from the organic acid anions. For Sample DIL 3, the sum of the carbon from the acid anions is $36 \%$ greater than the reported TOC. The cause(s) for this discrepancy is unknown.

The concentrations of phosphate $\left(\mathrm{PO}_{4}{ }^{3-}\right)$ in the liquid samples measured with IC can be compared with concentrations of $\mathrm{P}$ measured with inductively coupled plasma-atomic emission spectrometry (ICP-AES) and then recalculated as $\mathrm{PO}_{4}$. The difference between the recalculated ICP-AES and IC values ranges from $-11 \%$ to $+24 \%$. This degree of variation between the two data sets is probably due, in large part, to combined analytical errors. The trends of concentration versus boildown progress displayed by both the IC and ICP-AES data sets for phosphorus species are similar.

The concentrations of sulfate $\left(\mathrm{SO}_{4}{ }^{2-}\right)$ in the liquid samples measured with $\mathrm{IC}$ can be compared with concentrations of $\mathrm{S}$ measured with ICP-AES and then recalculated as $\mathrm{SO}_{4}$. The calculated ICP-AES $\mathrm{SO}_{4}$ values are 2-25\% greater than the IC sulfate concentrations for 10 of the 11 samples; the calculated $\mathrm{SO}_{4}$ concentration is $7 \%$ smaller than the IC sulfate value for Sample DIL 1. This degree of variation between the two data sets is also probably mostly due to combined analytical errors. The trends of concentration versus boildown progress displayed by both the IC and ICP-AES data sets for sulfur species are similar. 
Table 4-1. Results of Analyses of Boildown Sample Liquids. (2 sheets)

(All analysis results in units of $\mu \mathrm{g} / \mathrm{mL}$ )

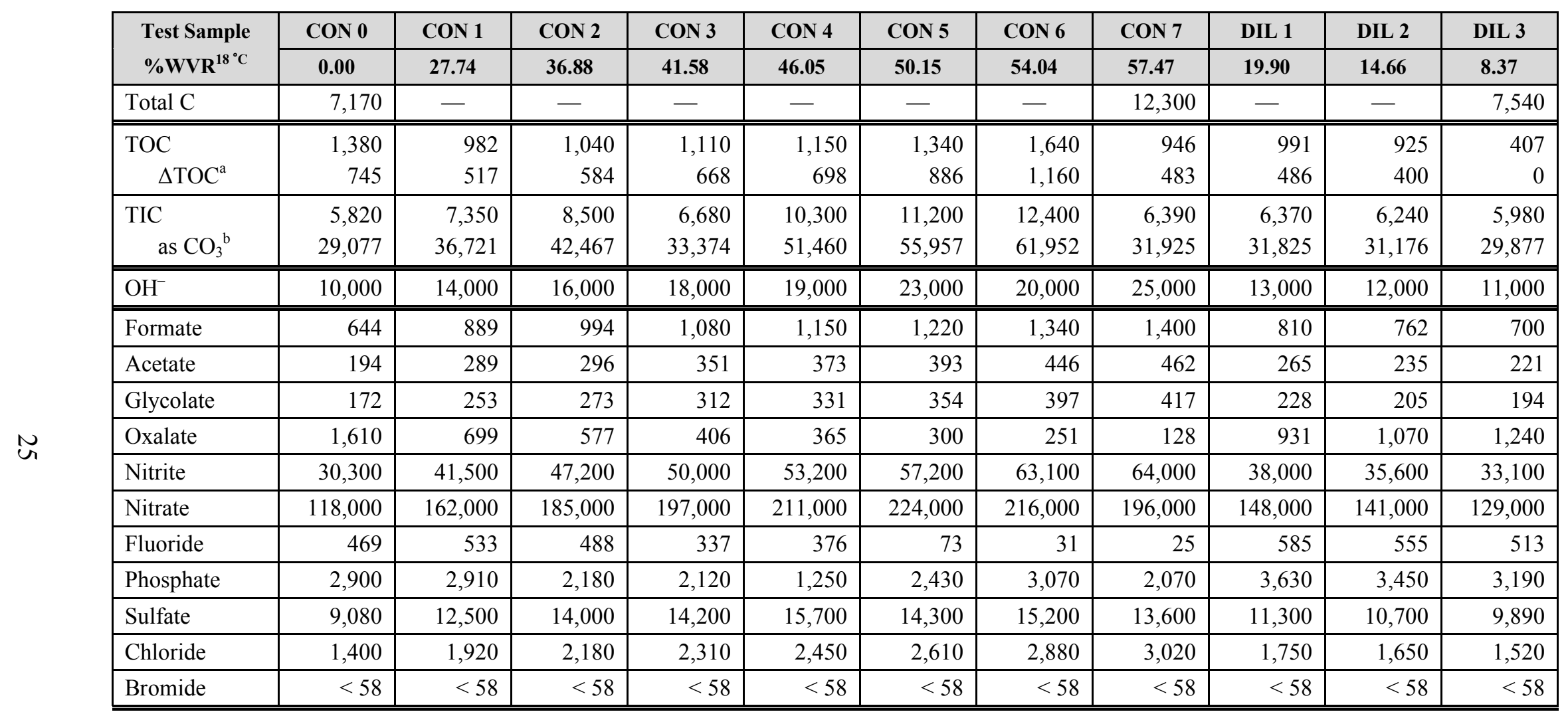


Table 4-1. Results of Analyses of Boildown Sample Liquids. (2 sheets)

(All analysis results in units of $\mu \mathrm{g} / \mathrm{mL}$ )

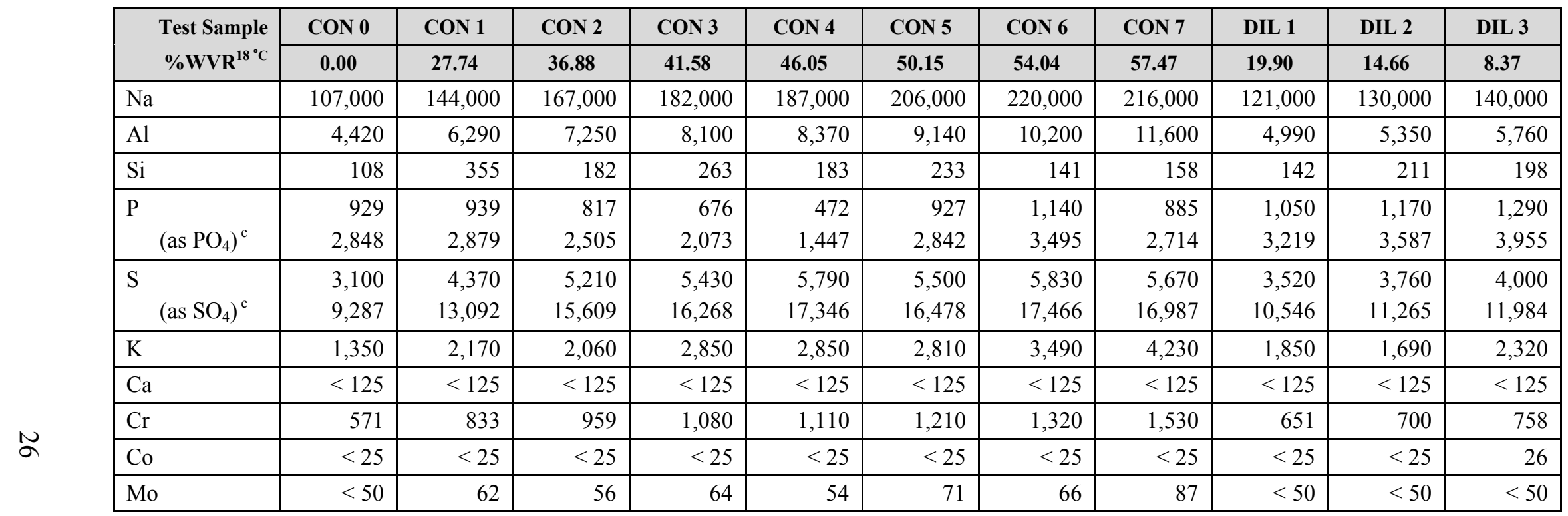

${ }^{\mathrm{a}} \Delta \mathrm{TOC} \mu \mathrm{g} / \mathrm{mL}=\mu \mathrm{g} / \mathrm{mL}$ TOC $-[(\mu \mathrm{g} / \mathrm{mL}$ Formate $\times 0.2668)+(\mu \mathrm{g} / \mathrm{mL}$ Acetate $\times 0.4068)+(\mu \mathrm{g} / \mathrm{mL}$ Glycolate $\times 0.3201)+(\mu \mathrm{g} / \mathrm{mL}$ Oxalate $\times 0.2729)]$

${ }^{\mathrm{b}} \mu \mathrm{g} / \mathrm{mL} \mathrm{CO}_{3}=\mu \mathrm{g} / \mathrm{mL} \mathrm{TIC} \times 4.9961$

${ }^{c} \mathrm{P}$ and $\mathrm{S}$ were analyzed by ICP-AES. Analysis results were converted to phosphate and sulfate as follows: $\mathrm{PO}_{4} \mu \mathrm{g} / \mathrm{mL}=\mu \mathrm{g} / \mathrm{mL} \mathrm{P} \times 3.0662$ and $\mathrm{SO}_{4} \mu \mathrm{g} / \mathrm{mL}=\mu \mathrm{g} / \mathrm{mL} \mathrm{S} \times 2.9959$ 


\subsection{DATA ANALYSIS}

\subsection{DENSITY}

In this report, bulk density or $\mathrm{D}_{\mathrm{Bulk}}$, is the density of a total sample, i.e., the density of the combined liquid and solid fractions of a sample. Liquid densities or $\mathrm{D}_{\text {Liq }}$ are the measured densities of the C-Liq portion of the samples processed in 15-mL centrifuge cones. The density of the initial composite is reported as a $\mathrm{D}_{\text {Bulk }}$ when measured in triplicate in $100-\mathrm{mL}$ volumetric flasks and as a $\mathrm{D}_{\mathrm{Liq}}$ when measured on the subsample in a $15-\mathrm{mL}$ cone.

\subsubsection{Bulk Density of Boildown Samples}

The $\mathrm{D}_{\mathrm{Bulk}}{ }^{26.8^{\circ} \mathrm{C}}$ for the initial composite is believed to be the most accurately measured density in this study. The $\mathrm{D}_{\text {Bulk }}{ }^{1{ }^{\circ} \mathrm{C}}$ values, tabulated in Table $3-3$, are based on volume measurements initiated while the boildown samples, at $18^{\circ} \mathrm{C}$, were in the $15-\mathrm{mL}$ centrifuge cones in which they were collected. These volume (and $\mathrm{D}_{\mathrm{Bulk}}{ }^{\circ}{ }^{\circ} \mathrm{C}$ ) measurements were made as carefully as possible but are probably slightly less accurate than those for the initial composite.

In Table B-2 (Attachment B), the additive volumes model calculations are reset to a base temperature of $18{ }^{\circ} \mathrm{C}$. The volume of the initial composite sample was reduced to account for cooling. Previous measurements (ARCHO 1974, "Densities of Caustic Waste Solutions as a Function of Temperature") showed that the thermal expansion coefficients of two synthetic tank waste concentrates were $4.409 \times 10^{-4}$ and $4.838 \times 10^{-4}(\Delta \mathrm{mL} / \mathrm{mL}) /{ }^{\circ} \mathrm{C}$ over a range of $22-56.5^{\circ} \mathrm{C}$. Another set of measurements (WRPS-0900372, "Results of Lifetime Testing of Anton Paar DMA 35N Portable Density Meter") showed that thermal expansion coefficients of a double-shell tank waste simulant were $3.757 \times 10^{-4}(\Delta \mathrm{mL} / \mathrm{mL}) /{ }^{\circ} \mathrm{C}$ from $18-30{ }^{\circ} \mathrm{C}$ and $6.843 \times 10^{-4}(\Delta \mathrm{mL} / \mathrm{mL}) /{ }^{\circ} \mathrm{C}$ from $30-42{ }^{\circ} \mathrm{C}$. An average value of $4.335 \times 10^{-4}(\Delta \mathrm{mL} / \mathrm{mL}) /{ }^{\circ} \mathrm{C}$ was used to adjust the initial composite volume. The corresponding $\mathrm{D}_{\text {Bulk }}{ }^{18^{\circ} \mathrm{C}}$ was $1.221 \mathrm{~g} / \mathrm{mL}$.

The calculated $\mathrm{D}_{\text {Model }}{ }^{\circ} \mathrm{C}$ and measured $\mathrm{D}_{\text {Bulk }}{ }^{18} \mathrm{C}$ values are plotted against $C R_{\text {Model }}{ }^{1{ }^{\circ} \mathrm{C}}$ in Figure 5-1. The $\mathrm{D}_{\mathrm{Liq}}{ }^{25.3{ }^{\circ} \mathrm{C}}$ values have also been replotted for comparison. In this figure and all other plots in this report, values for the initial test composite (CON 0) and the volume reduction sequence samples (CON 1 to CON 7) are displayed with solid data markers; values for the dilution sequence samples (DIL 1 to DIL 3) are displayed with hollow data markers of the same shape and border color.

The plot of measured $\mathrm{D}_{\text {Bulk }}{ }^{18} \mathrm{C}$ vs. $C R_{\text {Model }}{ }^{1{ }^{\circ} \mathrm{C}}$ in Figure $5-1$ clearly deviates from the linear projection of the additive volumes model. The concentrate volumes indicated by the $\mathrm{D}_{\mathrm{Bulk}} 18^{\circ} \mathrm{C}$ values are larger than those predicted by the additive volumes model. Small downward curvature in plots of density vs. $C R$ is common for concentrated solutions of chemical species found in tank wastes. It is also quite likely that as the quantity of solid precipitates in the concentrates increases, the additive volumes assumption of the model becomes an increasingly poor one. The pronounced decrease in the slope of the $\mathrm{D}_{\mathrm{Liq}}{ }^{25.3^{\circ} \mathrm{C}}$ plot beginning at Sample CON 5 suggests that this is a factor. 
Figure 5-1. Comparison of Model and Measured Bulk Densities.

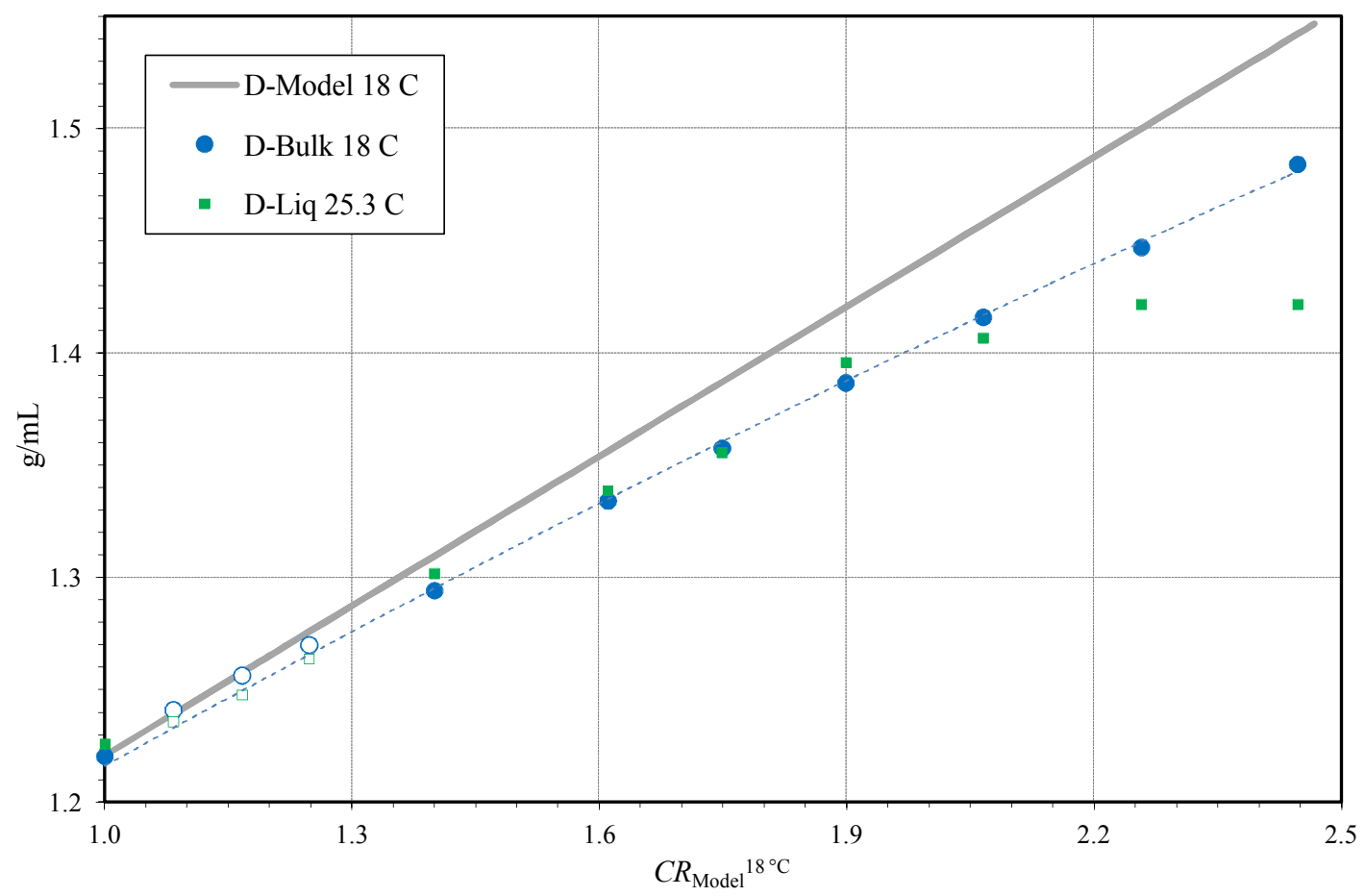

\subsubsection{Test Values of $C R$ and \%WVR}

The measured $\mathrm{D}_{\text {Bulk }}{ }^{1{ }^{\circ} \mathrm{C}}$ values can be used to calculate the virtual volumes of $18{ }^{\circ} \mathrm{C}$ pot concentrates at each step of the boildown test. These volumes can then be used to calculate boildown progress parameters, $C R^{18^{\circ} \mathrm{C}}$ and $\% \mathrm{WVR}^{18^{\circ} \mathrm{C}}$, that are not based on the additive volumes assumption of the model parameters. These calculations are shown in Table 5-1. The calculation chain proceeds down a column of the table for each boildown step.

1. The weight and volume of concentrate at the beginning of the step are entered. These values are the weight and volume of concentrate at the end of the previous step.

2. The weight of the concentrate is adjusted by the weight of water removed/added.

3. The new concentrate weight is converted to a new volume by dividing by $\mathrm{D}_{\mathrm{Bulk}}{ }^{18^{\circ} \mathrm{C}}$.

4. The $C R^{18^{\circ} \mathrm{C}}$ is calculated using Equations 3-1 and 3-5.

5. The $\% \mathrm{WVR}^{18{ }^{\circ} \mathrm{C}}$ is calculated using Equation 3-6.

6. The final concentrate weight is calculated by subtracting the weight of sample removed.

7. The final step concentrate weight is converted to a final step volume by dividing by $\mathrm{D}_{\text {Bulk }}{ }^{18^{\circ} \mathrm{C}}$. 
LAB-RPT-12-00008, R0

Table 5-1. Calculation of Test Values of $C R$ and \%WVR.

\begin{tabular}{|c|c|c|c|c|c|c|c|c|}
\hline & CON 0 & CON 1 & CON 2 & CON 3 & CON 4 & CON 5 & CON 6 & CON 7 \\
\hline Wt Concentrate $(\mathrm{g})$ & 578.170 & 578.170 & 427.233 & 367.355 & 330.019 & 294.702 & 260.446 & 227.625 \\
\hline Vol Con & 473.659 & 473.659 & 330.044 & 275.303 & 243.038 & 212.485 & 183.910 & 157.281 \\
\hline$\Delta \mathrm{H}_{2} \mathrm{O}(\mathrm{g})$ & 0.000 & 135.117 & 2.538 & 21.387 & 18.717 & 16.656 & 15.062 & 11.606 \\
\hline Wt Concentrate $(\mathrm{g})$ & 578.170 & 443.053 & 384.695 & 345.968 & 311.302 & 278.046 & 245.384 & 216.019 \\
\hline $\mathrm{D}_{\text {Bulk }}{ }^{1{ }^{\circ} \mathrm{C}}(\mathrm{g} / \mathrm{mL})$ & 1.2206 & 1.2945 & 1.3344 & 1.3579 & 1.3869 & 1.4162 & 1.4472 & 1.4843 \\
\hline Vol Concentrate $(\mathrm{mL})$ & 473.657 & 342.266 & 288.297 & 254.784 & 224.454 & 196.338 & 169.552 & 145.538 \\
\hline$C R^{18^{\circ} \mathrm{C}}$ & 1.0000 & 1.3839 & 1.5843 & 1.7119 & 1.8536 & 2.0061 & 2.1759 & 2.3515 \\
\hline$\% \mathrm{WVR}^{18^{\circ} \mathrm{C}}$ & 0.000 & 27.740 & 36.880 & 41.585 & 46.052 & 50.151 & 54.043 & 57.474 \\
\hline Wt Sample Rmvd (g & 0.000 & 15.820 & 17.340 & 15.949 & 16.600 & 17.600 & 17.759 & 19.869 \\
\hline Wt Concentrate (g) & 578.170 & 427.233 & 367.355 & 330.019 & 294.702 & 260.446 & 227.625 & 196.150 \\
\hline Vol Concentrate $(\mathrm{mL})$ & 473.659 & 330.044 & 275.303 & 243.038 & 212.485 & 183.910 & 157.281 & 132.151 \\
\hline
\end{tabular}

\begin{tabular}{|c|c|c|c|}
\hline & DIL 1 & DIL 2 & DIL 3 \\
\hline Wt Concentrate (g) & 196.150 & 299.867 & 299.658 \\
\hline Vol Concentrate $(\mathrm{mL})$ & 132.151 & 236.067 & 238.453 \\
\hline$\Delta \mathrm{H}_{2} \mathrm{O}(\mathrm{g})$ & -120.040 & -16.200 & -18.130 \\
\hline Wt Concentrate $(\mathrm{g})$ & 316.190 & 316.067 & 317.788 \\
\hline $\mathrm{D}_{\mathrm{Bulk}}{ }^{18^{\circ} \mathrm{C}}(\mathrm{g} / \mathrm{mL})$ & 1.2703 & 1.2567 & 1.2413 \\
\hline Vol Concentrate $(\mathrm{mL})$ & 248.918 & 251.510 & 256.014 \\
\hline$C R^{18{ }^{\circ} \mathrm{C}}$ & 1.2484 & 1.1718 & 1.0914 \\
\hline$\% W V R^{18}{ }^{\circ} \mathrm{C}$ & 19.899 & 14.659 & 8.374 \\
\hline Wt Sample Rmvd (g) & 16.323 & 16.409 & 15.864 \\
\hline Wt Concentrate (g) & 299.867 & 299.658 & 301.924 \\
\hline Vol Concentrate $(\mathrm{mL})$ & 236.067 & 238.453 & 243.235 \\
\hline
\end{tabular}

The values of $C R^{18^{\circ} \mathrm{C}}$ and $\% \mathrm{WVR}{ }^{18^{\circ} \mathrm{C}}$ calculated in Table 5-1 are the boildown progress parameters used throughout the remainder of this report. The $\mathrm{D}_{\mathrm{Bulk}}{ }^{18}{ }^{\circ} \mathrm{C}$ values are replotted against $C R_{\text {Model }}{ }^{\circ} \mathrm{C}$ and $C R^{18^{\circ} \mathrm{C}}$ in Figure 5-2 for comparison. 
Figure 5-2. Bulk Densities at $18{ }^{\circ} \mathrm{C}$ versus Concentration Ratio.

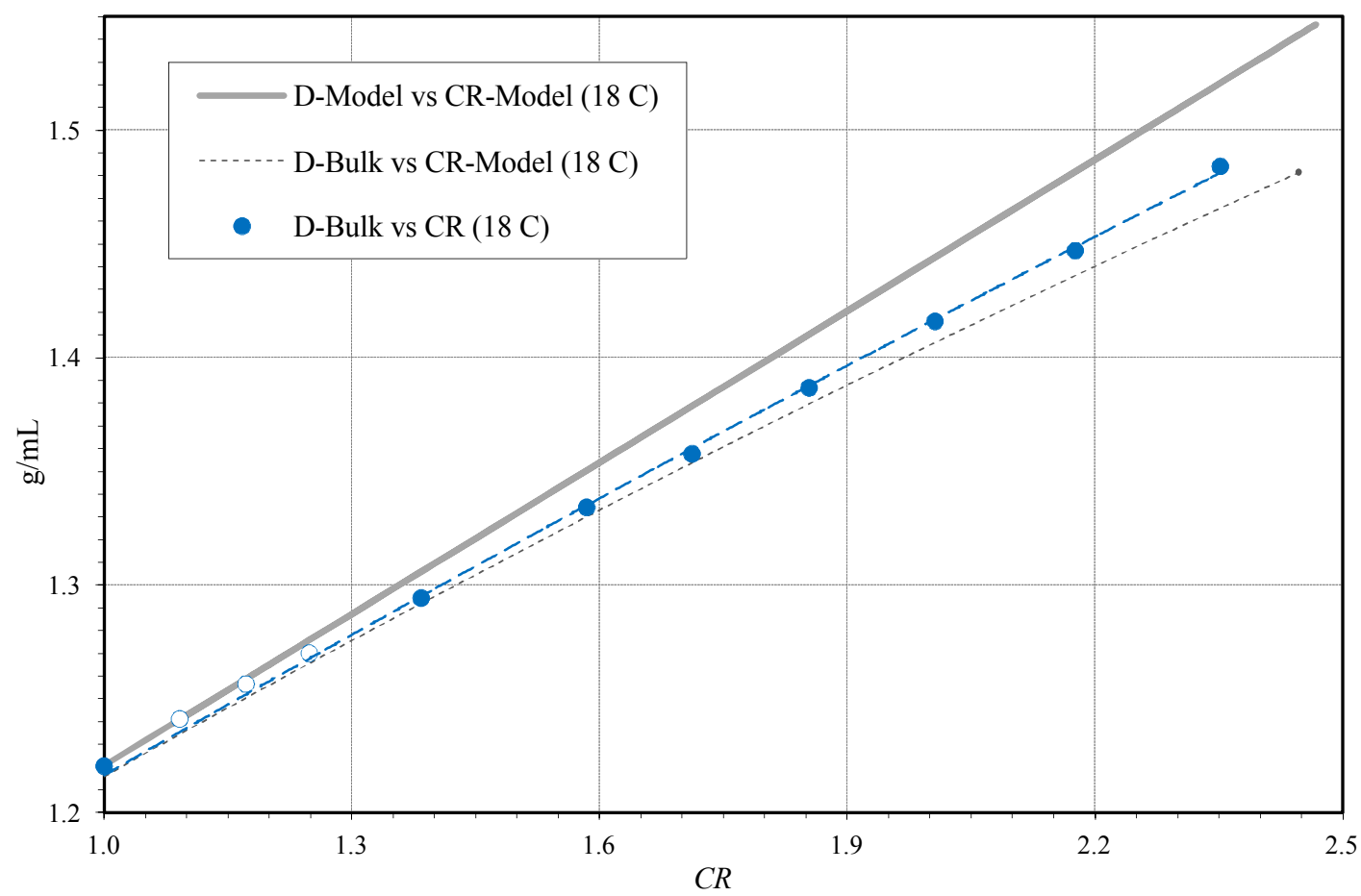

\subsubsection{Volumes and Densities at Process Temperatures}

Estimates of $\mathrm{D}_{\text {Bulk }}$ of the concentrated slurries at boildown process temperatures (boiling temperatures) are of interest as an indicator of real-time densities that may be observed during a 242-A Evaporator campaign. To estimate these in-process $\mathrm{D}_{\text {Bulk }}$ values, the volumes of the boildown samples at $18{ }^{\circ} \mathrm{C}$ were adjusted to estimated volumes at the boiling temperatures of the pot concentrates at 60 Torr.

The temperature adjustment process is shown in Table 5-2. The total and C-Slds volumes at $18{ }^{\circ} \mathrm{C}$ are the base measurements. The fraction of the measured C-Slds volumes that are true solids must be assumed and is assigned a value of 0.5 in the table. The volumes of the solid and liquid portions of the samples at $18^{\circ} \mathrm{C}$ are then calculated. A thermal expansion coefficient of $4.335 \times 10^{-4}(\Delta \mathrm{mL} / \mathrm{mL}) /{ }^{\circ} \mathrm{C}$ was used to adjust the volumes of the liquids from $18-30{ }^{\circ} \mathrm{C}$. A coefficient of $5.364 \times 10^{-4}(\Delta \mathrm{mL} / \mathrm{mL}) /{ }^{\circ} \mathrm{C}$ was used to adjust the volumes from $30{ }^{\circ} \mathrm{C}$ to boiling temperatures at 60 Torr. The sources of the thermal expansion factors were noted in Section 5.1.1.

The adjusted total sample volumes were then calculated by adding the volumes of the $18{ }^{\circ} \mathrm{C}$ solids and the adjusted liquid volumes. Temperature adjusted densities, $\mathrm{D}_{\mathrm{Bulk}}{ }^{60}$ Torr , are simply the sample weights divided by the adjusted total volumes. 
Table 5-2. Adjusted Sample Volumes and Densities at Process Temperatures.

[Adjusted densities of samples at boiling temperatures at 60 Torr $\left(\mathrm{T}_{3}\right)$ in bottom-right column.]

\begin{tabular}{|c|c|c|c|c|c|c|}
\hline & \multirow{4}{*}{$\begin{array}{l} \\
\text { Vol }_{\text {Liquid }} \\
\text { at } T_{1} \\
(\mathrm{~mL}) \\
\end{array}$} \\
\hline & & & & \multirow{2}{*}{\multicolumn{2}{|c|}{$\frac{\text { Vol }_{\text {Solids }} / \mathbf{V o l}_{\text {C-SIds }}}{0.500}$}} & \\
\hline & & & & & & \\
\hline Sample & $\begin{array}{c}\mathbf{W t}_{\text {Total }} \\
(\mathrm{g}) \\
\end{array}$ & $\begin{array}{r}\mathrm{T}_{1} \\
\left({ }^{\circ} \mathrm{C}\right) \\
\end{array}$ & $\begin{array}{l}\text { Vol }_{\text {Total }} \\
\text { at } T_{1} \\
(\mathrm{~mL}) \\
\end{array}$ & $\begin{array}{l}\text { Vol }_{\text {C-Slds }} \\
\text { at } \mathbf{T}_{1} \\
(\mathrm{~mL}) \\
\end{array}$ & $\begin{array}{l}\text { Vol }_{\text {Solids }} \\
\text { at } T_{1} \\
(\mathrm{~mL}) \\
\end{array}$ & \\
\hline $\mathrm{CON}-0$ & 14.674 & 18.0 & 12.025 & 0.00 & 0.000 & 12.025 \\
\hline $\mathrm{CON}-1$ & 15.820 & 18.0 & 12.221 & 0.25 & 0.125 & 12.096 \\
\hline $\mathrm{CON}-2$ & 17.340 & 18.0 & 12.995 & 0.35 & 0.175 & 12.820 \\
\hline $\mathrm{CON}-3$ & 15.949 & 18.0 & 11.745 & 0.45 & 0.225 & 11.520 \\
\hline $\mathrm{CON}-4$ & 16.600 & 18.0 & 11.969 & 0.60 & 0.300 & 11.669 \\
\hline CON-5 & 17.600 & 18.0 & 12.428 & 0.70 & 0.350 & 12.078 \\
\hline CON-6 & 17.759 & 18.0 & 12.271 & 0.85 & 0.425 & 11.846 \\
\hline $\mathrm{CON}-7$ & 19.869 & 18.0 & 13.386 & 4.90 & 2.450 & 10.936 \\
\hline DIL-1 & 16.323 & 18.0 & 12.850 & 0.15 & 0.075 & 12.775 \\
\hline DIL-2 & 16.409 & 18.0 & 13.058 & 0.10 & 0.050 & 13.008 \\
\hline DIL-3 & 15.864 & 18.0 & 12.780 & 0.07 & 0.035 & 12.745 \\
\hline
\end{tabular}

$\mathrm{T}=$ temperature

\begin{tabular}{|c|c|c|c|c|c|c|}
\hline \multirow[b]{3}{*}{ Sample } & \multicolumn{4}{|c|}{$(\Delta \mathrm{mL} / \mathrm{mL}) /{ }^{\circ} \mathbf{C}$} & \multirow[b]{3}{*}{$\begin{array}{c}V_{\text {Vol }}^{\text {Total }} \\
\text { at } \mathbf{T}_{3} \\
(\mathrm{~mL}) \\
\end{array}$} & \multirow[b]{3}{*}{$\begin{array}{c}D_{\text {Bulk }} \\
\text { at } T_{3} \\
(\mathrm{~g} / \mathrm{mL}) \\
\end{array}$} \\
\hline & \multicolumn{2}{|c|}{0.00043349} & \multicolumn{2}{|c|}{0.00053635} & & \\
\hline & $\begin{array}{c}\mathbf{T}_{2} \\
\left({ }^{\circ} \mathrm{C}\right)\end{array}$ & $\begin{array}{c}\text { Vol }_{\text {Liquid }} \\
\text { at } \mathbf{T}_{2} \\
(\mathrm{~mL})\end{array}$ & $\begin{array}{c}\mathrm{T}_{3} \\
\left({ }^{\circ} \mathrm{C}\right)\end{array}$ & $\begin{array}{c}\text { Vol }_{\text {Liquid }} \\
\text { at } T_{3} \\
(\mathrm{~mL})\end{array}$ & & \\
\hline $\mathrm{CON}-0$ & 30.0 & 12.088 & 44.87 & 12.184 & 12.184 & 1.204 \\
\hline $\mathrm{CON}-1$ & 30.0 & 12.159 & 46.26 & 12.265 & 12.390 & 1.277 \\
\hline $\mathrm{CON}-2$ & 30.0 & 12.887 & 47.45 & 13.007 & 13.182 & 1.315 \\
\hline $\mathrm{CON}-3$ & 30.0 & 11.580 & 47.84 & 11.691 & 11.916 & 1.338 \\
\hline $\mathrm{CON}-4$ & 30.0 & 11.730 & 49.08 & 11.850 & 12.150 & 1.366 \\
\hline $\mathrm{CON}-5$ & 30.0 & 12.141 & 49.92 & 12.270 & 12.620 & 1.395 \\
\hline $\mathrm{CON}-6$ & 30.0 & 11.907 & 50.81 & 12.040 & 12.465 & 1.425 \\
\hline $\mathrm{CON}-7$ & 30.0 & 10.993 & 51.50 & 11.120 & 13.570 & 1.464 \\
\hline DIL-1 & 30.0 & 12.842 & 45.86 & 12.951 & 13.026 & 1.253 \\
\hline DIL-2 & 30.0 & 13.075 & 45.66 & 13.185 & 13.235 & 1.240 \\
\hline DIL-3 & 30.0 & 12.812 & 45.26 & 12.916 & 12.951 & 1.225 \\
\hline
\end{tabular}

In the above calculations the $18{ }^{\circ} \mathrm{C} \mathrm{C}$-Slds are assumed to contain a constant $50 \%$ interstitial liquid, and the volumes of solids present at $18{ }^{\circ} \mathrm{C}$ and at process temperatures are assumed to be equal. Both these assumptions are almost certainly incorrect. The impact of the assumed solids content of the samples at elevated temperature on the adjusted volumes increases as the solids volume increases and is not large until large volumes of solids are present. Trial calculations showed that the temperature adjusted volume of the sample with the largest volume of solids, 
Sample CON 7, decreased by $0.062 \mathrm{~mL}$ when the assumed solids fraction of the C-Slds was increased from 0.125 to 0.875 . The corresponding increase in $\mathrm{D}_{\text {Bulk }}{ }^{60 \text { Torr }}$ was from 1.461 to $1.468 \mathrm{~g} / \mathrm{mL}$

The measured $\mathrm{D}_{\mathrm{Bulk}}{ }^{10^{\circ} \mathrm{C}}$ and estimated $\mathrm{D}_{\text {Bulk }}{ }^{60}$ Torr values are plotted against $\% \mathrm{WVR}^{18^{\circ} \mathrm{C}}$ in Figure 5-3. The estimated $\mathrm{D}_{\mathrm{Bulk}}{ }^{60}$ Torr values are based on significant assumptions (true solids content at process temperatures) and indirect supporting data (liquid thermal expansion coefficients). The temperature-adjusted values do indicate, however, that real-time measurements of the densities of concentrated boildown slurries will return values that are smaller than those based on measurements at lower temperatures. For Samples CON 5 and CON 6, collected before the quantity of solids present began to increase precipitously, the estimated $\mathrm{D}_{\mathrm{Bulk}}{ }^{60 \mathrm{Torr}}$ are $0.022 \mathrm{~g} / \mathrm{mL}$ smaller than the measured $\mathrm{D}_{\mathrm{Bulk}}{ }^{1{ }^{\circ} \mathrm{C}}$ values over a wide range of assumed solids content.

Figure 5-3. Bulk Densities at Process Temperatures versus $\% \mathrm{WVR}^{18^{\circ} \mathrm{C}}$.

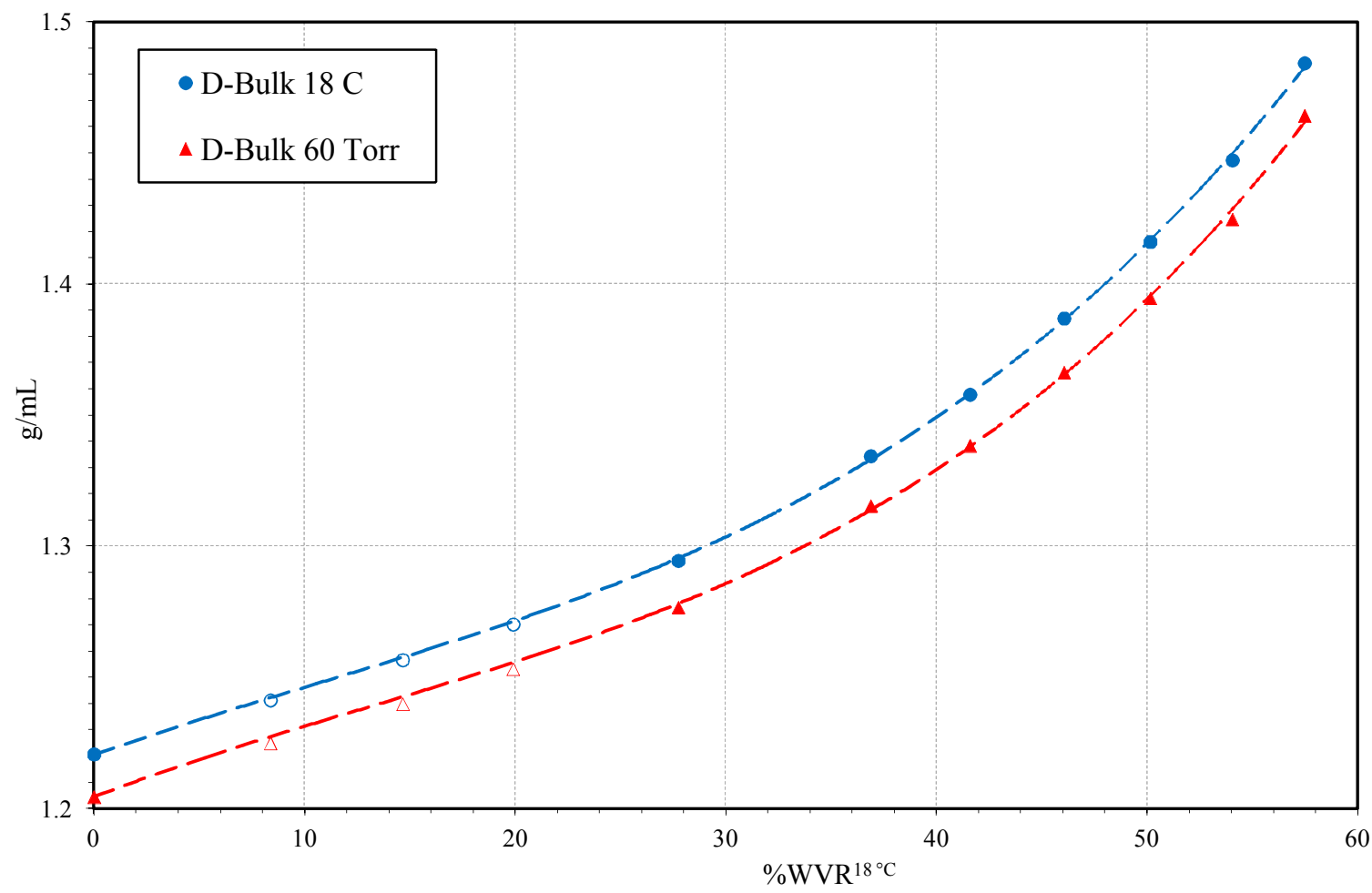

Fit Lines: $\mathrm{D}_{\text {Bulk }}{ }^{1{ }^{\circ} \mathrm{C}}=\left(1.1721 \times 10^{-6}\right)(\% \mathrm{WVR})^{3}-\left(3.7166 \times 10^{-5}\right)(\% \mathrm{WVR})^{2}+\left(2.8222 \times 10^{-3}\right)(\% \mathrm{WVR})+1.2206$ $\mathrm{D}_{\text {Bulk }} 60$ Torr $=\left(1.3324 \times 10^{-6}\right)(\% \mathrm{WVR})^{3}-\left(5.2423 \times 10^{-5}\right)(\% \mathrm{WVR})^{2}+\left(3.0858 \times 10^{-3}\right)(\% \mathrm{WVR})+1.2044$

\subsection{BOILDOWN TEMPERATURE CURVES}

The boiling temperatures, $\left(\mathrm{T}_{\mathrm{Corr}}\right)$ of the AP-107 liquid/slurries at the three nominal test pressures of 40,60, and 80 Torr are plotted against boildown progress in Figure 5-4. The boiling 
temperatures are taken from Table B-2 in Attachment B. Boiling temperatures are plotted against \%WVR ${ }^{1{ }^{\circ} \mathrm{C}}$ in Figure 5-4(a) and against estimated $\mathrm{D}_{\mathrm{Bulk}}{ }^{60}$ Torr in Figure 5-4(b).

The temperature curves shown in the figures were constrained to pass through the reference boiling temperatures and densities of pure water at the nominal test pressures. The resulting curves display steadily increasing boiling temperatures as the volume reduction progressed without any significant discontinuities. Within the estimated measurement precision, boiling temperatures measured during the dilution sequence at 60 Torr were those that would have been predicted based on the concentration sequence measurements.

Figure 5-4. Boiling Temperature versus Boildown Progress.
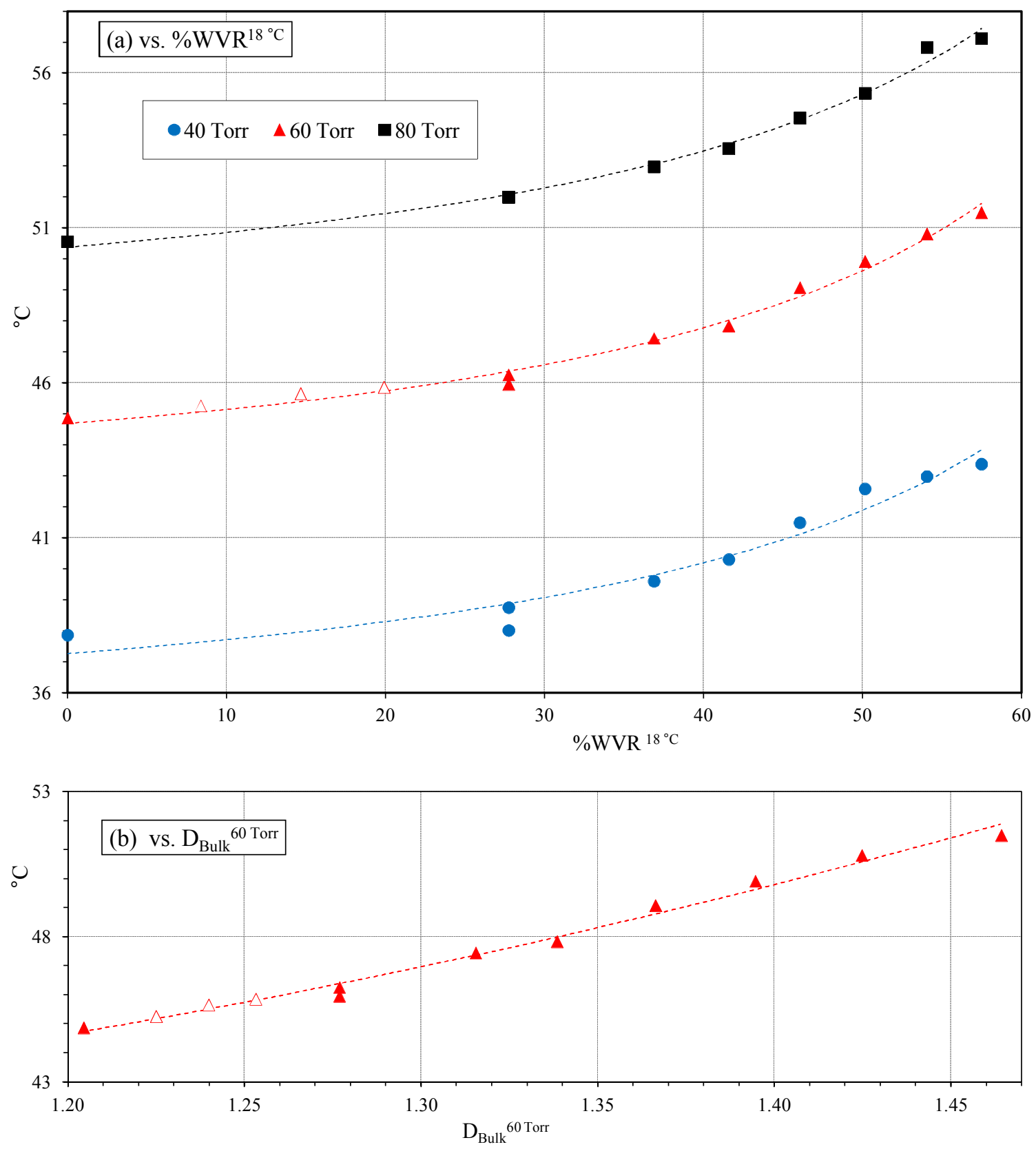


\subsection{QUANTITY OF SOLIDS IN COOL CONCENTRATES}

\subsubsection{Boildown Volume Reduction Samples}

The quantities of solids found in the 7 samples that were withdrawn from the boildown pot during the volume reduction sequence $(\mathrm{CON} 1-7)$ and then cooled to $18{ }^{\circ} \mathrm{C}$ for 8 days are graphically displayed in Figure 5-5. The quantity of solids data was tabulated in Table 3-3. Three quantities are displayed against $\mathrm{D}_{\mathrm{Bulk}}{ }^{60 \mathrm{Torr}}$ in Figure 5-5(a): the vol\% S-Slds found after a maximum of $45 \mathrm{hrs}^{4}$ at hot cell ambient temperature $\left(\approx 25.2{ }^{\circ} \mathrm{C}\right)$, the vol\% S-Slds found after the samples had been in the $18{ }^{\circ} \mathrm{C}$ water bath for 7 days, and the vol\% C-Slds found after the samples had been in the water bath for 8 days and were then centrifuged. Photographs of the S-Slds and C-Slds in the samples are presented in Attachment C.

Solids were present in all of the boildown samples at $18{ }^{\circ} \mathrm{C}$, at hot cell ambient temperature, and at process temperatures. The vol\% of solids in the cooled CON 2 concentrate was slightly greater than in Sample CON 1. The vol\% of solids in the $18{ }^{\circ} \mathrm{C}$ concentrates from Steps CON 2-5 changed little. The vol $\%$ of solids in the CON 6 concentrate at $18{ }^{\circ} \mathrm{C}$ increased slightly. A large increase in the volumes of solids in the CON 7 concentrate signaled the generation of the end-point slurry.

Figure 5-5(a) and the photographs in Attachment $\mathrm{C}$ indicate that most of the solids in the boildown samples were present after cooling to ambient hot cell temperatures. The volumes of additional solids that formed while the samples were in the $18^{\circ} \mathrm{C}$ water bath were smaller than the decreases in the volumes of the S-Slds layers due to compaction. Sample photographs and observations during the boildown also suggest that a significant portion of the solids found in the $18^{\circ} \mathrm{C}$ concentrate samples were already present in the boildown pot at process temperatures.

Comparison of the vol\% S-Slds and vol\% C-Slds in the samples after cooling to $18{ }^{\circ} \mathrm{C}$ for 8 days is informative. The samples settled to produce a clear supernatant liquid within a few hours after removal from the boildown pot. Figure 5-5(a) indicates that the S-Slds layers then compacted slowly. The vol\% C-Slds data suggests that the initial volume of S-Slds found in concentrated evaporator feeds might be expected to decrease by as much as $50 \%$ as the S-Slds compact over time.

In Figure 5-5(b) the vol\% C-Slds and wt $\%$ C-Slds data are compared. Both of these quantities can be difficult to measure accurately when small quantities of solids are present. Nevertheless, the two data sets display very similar trends in increase of solids with boildown progress.

\footnotetext{
${ }^{4}$ Sample CON 1 sat at hot cell ambient temperature for 45 hrs. The remaining 6 samples sat at hot cell ambient temperature for $26-18 \mathrm{hrs}$.
} 
Figure 5-5. Quantity of Solids in Cooled Concentrates.
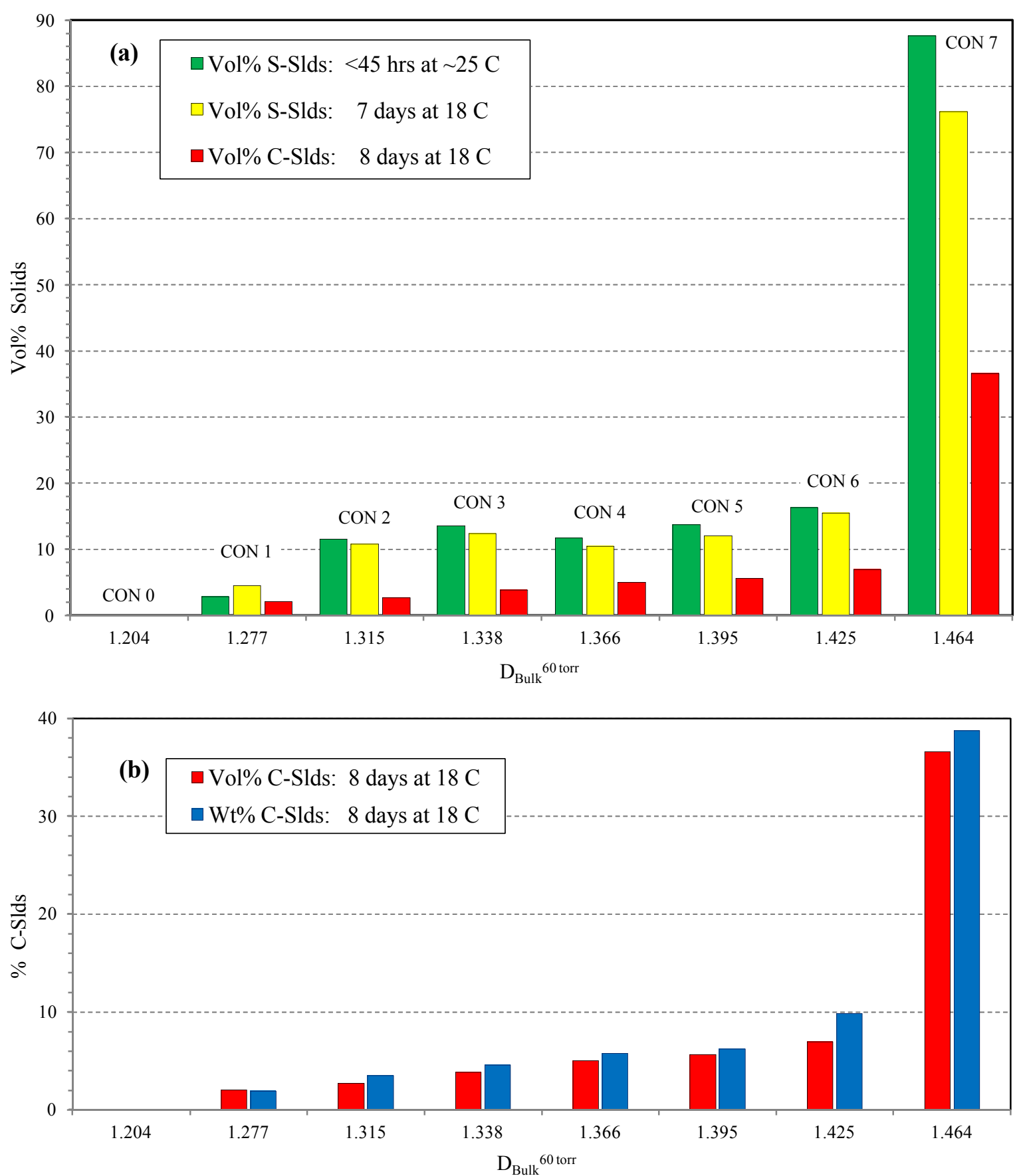

Part of the apparent increase in the amounts of solids present in the concentrates as the volume reduction progresses is due solely to the reduction in the volume of the test slurry. The predicted quantity of solids that would be found in a sample if solids formation ceased after the preceeding boildown step is:

Predicted $\%$ Slds $=(\%$ Slds at the end of the previous step $)\left(C R_{\text {Step }}\right)$ 
The predicted and measured quantities of solids present in the boildown volume reduction samples are displayed in Figure 5-6 for the vol\% and $w \mathrm{t} \% \mathrm{C}$-Slds data $\left(18{ }^{\circ} \mathrm{C}\right)$. This format emphasizes that the quantities of new solids in the CON2-CON 6 concentrates were relatively small and relatively consistent. By contrast, the end-point slurry (CON 7) resulted from the formation of a large quantity of new solids.

Figure 5-6. Quantities of New Solids in Concentrates.
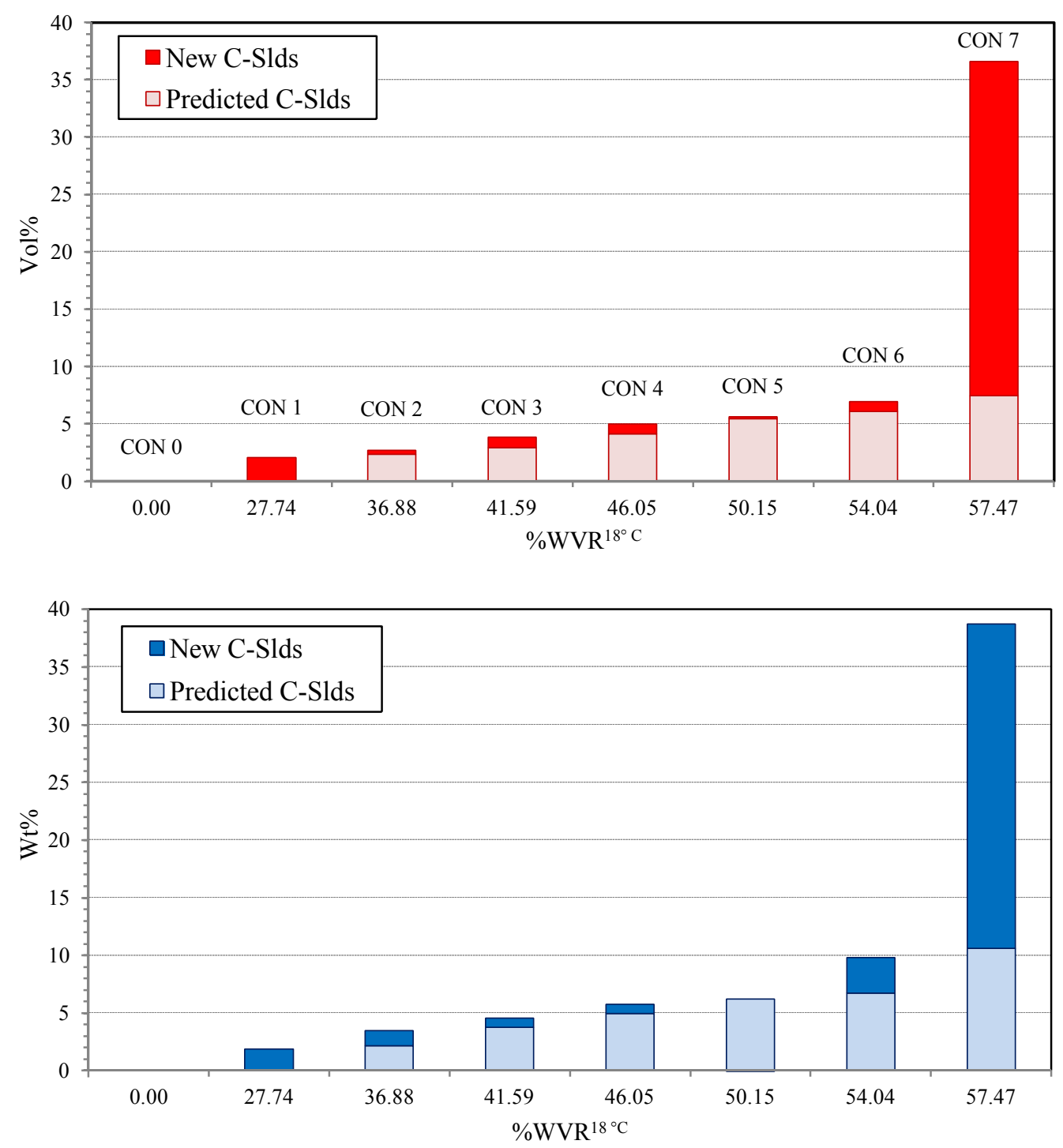

\subsubsection{End-point Slurry Dilution Samples}

The quantities of solids found in the three dilution sequence samples, DIL 1-3, are displayed in Figure 5-7. Data for the vol\% C-Slds and wt $\%$ C-Slds found in the samples after cooling to $18^{\circ} \mathrm{C}$ for 8 days are shown. 
Initially, solids were not formed in the CON 1 concentrate at process temperatures. Solids did form after the concentrate cooled to ambient temperature overnight; however, the solids did not redissolve when the CON 1 slurry was heated back to process temperatures. The dilution sample data confirms that the test slurry was saturated with slightly soluble species well before concentration to $27.74 \%$ WVR. Indeed, Sample DIL 3 shows that given sufficient time and/or nucleation sites, solids will precipitate from cooled concentrates after 8.37 \%WVR (or less).

Figure 5-7. Quantity of Solids in Dilution Samples at $18^{\circ} \mathrm{C}$.

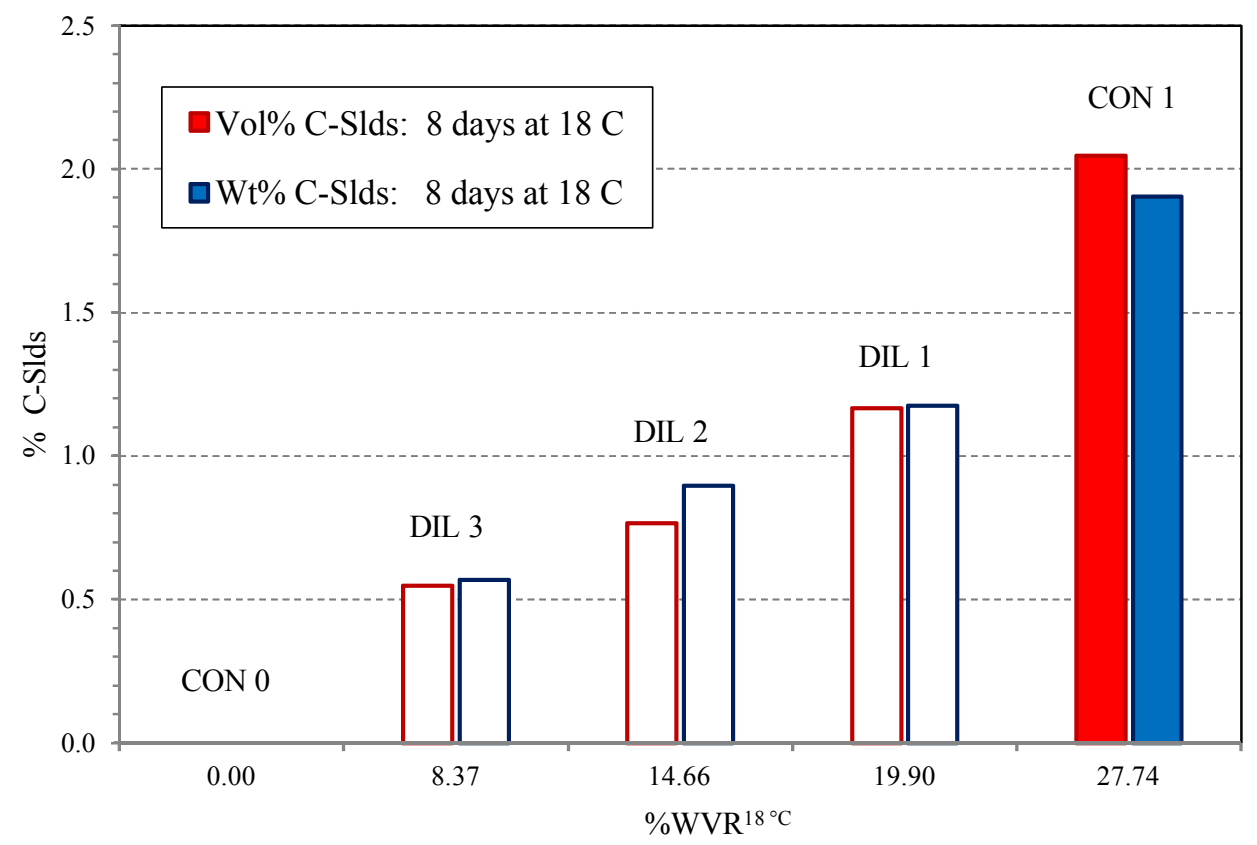

\subsubsection{Calculated Weights of Solids in Boildown Samples}

A check of the volume and density measurements/calculations performed in this study can be made by calculating the weights of dry solids predicted to be present after the concentrates from each volume reduction step cooled to $18{ }^{\circ} \mathrm{C}$. After conversion to $\mathrm{wt} \%$ dry solids values, these calculated weights can be compared to the measured wt\% wet C-Slds values.

The calculation series is shown in Table 5-3. Proceeding down a column for each boildown step, the following calculations are performed (rows where the calculations are performed are highlighted).

1. The final volume of the concentrate at $18{ }^{\circ} \mathrm{C}\left(\operatorname{Vol}_{\text {Step }}{ }^{1{ }^{\circ} \mathrm{C}}\right)$ is calculated:

$$
\mathrm{Vol}_{\text {Initial }}{ }^{\circ} \mathrm{C} / C R^{18^{\circ} \mathrm{C}}
$$

2. The final weight of the step concentrate, $\mathrm{Wt}_{\mathrm{Step}}$, is calculated:

$$
\left(\text { Vol }_{\text {Step }}{ }^{18^{\circ} \mathrm{C}}\right)\left(\mathrm{D}_{\text {Bulk }}{ }^{1{ }^{\circ} \mathrm{C}}\right)
$$

3. The estimated volume of liquid in the concentrate at $18{ }^{\circ} \mathrm{C}, \operatorname{Vol}_{\mathrm{Liq}}{ }^{1{ }^{\circ} \mathrm{C}}$, is calculated:

$$
\left(\operatorname{Vol}_{\text {Step }}{ }^{1{ }^{\circ} \mathrm{C}}\right)\left(f_{\text {Liq }}\right)
$$


4. The weight of the liquid in the concentrate, Wt Liquid, is calculated:

$$
\left(\mathrm{Vol}_{\mathrm{Liq}}{ }^{1{ }^{\circ} \mathrm{C}}\right)\left(\mathrm{D}_{\mathrm{Liq}}{ }^{1{ }^{\circ} \mathrm{C}}\right)
$$

5. The weight of dry solids in the concentrate, Wt Dry Solids, is calculated:

$$
\mathrm{Wt}_{\text {Step }}-\mathrm{Wt} \text { Liquid }
$$

6. The $\mathrm{wt} \%$ of dry solids in the concentrate is calculated:

(Wt Dry Solids / Wt $\left.t_{\text {Step }}\right)(100)$

\begin{tabular}{|c|c|c|c|c|c|c|c|c|c|}
\hline \multicolumn{2}{|l|}{ Step } & CON 0 & CON 1 & CON 2 & CON 3 & CON 4 & CON 5 & CON 6 & CON 7 \\
\hline \multicolumn{2}{|c|}{$\% W_{V R}{ }^{18^{\circ} \mathrm{C}}$} & 0.00 & 27.76 & 36.90 & 41.60 & 46.07 & 50.17 & 554.06 & 57.49 \\
\hline $\mathrm{Vol}_{\text {Initial }} 18^{\circ} \mathrm{C}$ & $\mathrm{mL}$ & 473.66 & - & - & - & - & - & - & - \\
\hline$C R^{18^{\circ} \mathrm{C}}$ & & 1.000 & 1.384 & 1.584 & 1.712 & 1.854 & 2.006 & 2.176 & 2.352 \\
\hline $\mathrm{Vol}_{\text {Step }} 18^{\circ} \mathrm{C}$ & $\mathrm{mL}$ & 473.7 & 342.3 & 299.0 & 276.7 & 255.5 & 236.1 & 217.7 & 201.4 \\
\hline $\mathrm{D}_{\mathrm{Bulk}} 18^{\circ} \mathrm{C}$ & $\mathrm{g} / \mathrm{mL}$ & 1.221 & 1.294 & 1.334 & 1.358 & 1.387 & 1.416 & 1.447 & 1.484 \\
\hline $\mathrm{Wt}_{\text {Step }}$ & $\mathrm{g}$ & 578.2 & 443.0 & 398.9 & 375.7 & 354.4 & 334.4 & 315.0 & 299.0 \\
\hline$f_{\text {Liq }}$ & & 1.000 & 0.990 & 0.986 & 0.981 & 0.975 & 0.972 & 0.965 & 0.817 \\
\hline $\mathrm{Vol}_{\mathrm{Liq}}{ }^{10^{\circ} \mathrm{C}}$ & $\mathrm{mL}$ & 473.7 & 338.8 & 295.0 & 271.4 & 249.1 & 229.5 & 210.1 & 164.6 \\
\hline $\mathrm{D}_{\mathrm{Liq}}{ }^{18^{\circ} \mathrm{C}}$ & $\mathrm{g} / \mathrm{mL}$ & 1.220 & 1.296 & 1.324 & 1.347 & 1.376 & 1.407 & 1.402 & 1.434 \\
\hline Wt Liquid & $\mathrm{g}$ & 578.0 & 439.2 & 390.4 & 365.7 & 342.8 & 322.9 & 294.7 & 236.0 \\
\hline Wt Dry Solids & $\bar{g}$ & 0.2 & 3.9 & 8.5 & 10.0 & 11.6 & 11.5 & 20.4 & 63.0 \\
\hline $\mathrm{Wt} \%$ Dry Soli & & 0.0 & 0.9 & 2.1 & 2.7 & 3.3 & 3.4 & 6.5 & 21.1 \\
\hline $\mathrm{Wt} \%$ Wet $18^{\circ}$ & C-Slds & 0.0 & 1.9 & 3.5 & 4.6 & 5.8 & 6.2 & 9.8 & 38.8 \\
\hline
\end{tabular}

Table 5-3. Estimated Dry Weights of Solids in Concentrates at $18{ }^{\circ} \mathrm{C}$.

The liquid fraction, $f_{\text {Liq }}$, in each step concentrate was estimated by assuming that the C-Slds from each concentrate contained $50 \mathrm{vol} \%$ solids and $50 \mathrm{vol} \%$ interstitial liquid. This was the same assumption used to calculate the total volume of liquid in the boildown samples at $18{ }^{\circ} \mathrm{C}$ (Section 5.1.3).

The calculated $\mathrm{wt} \%$ dry solids in the pot concentrates and the $\mathrm{wt} \%$ wet $18{ }^{\circ} \mathrm{C} \mathrm{C}$-Slds measured in the boildown samples (from Table 3-3) are compared graphically in Figure 5-8. The two values display a very similar trend in solids weight versus boildown progress. The calculated $\mathrm{wt} \%$ dry solids values are 46 to $66 \%$ of the $\mathrm{wt} \%$ wet C-Slds values; within the range of commonly observed differences between wet and dry C-Slds. The relative agreement of the calculated and measured solids weights suggests that the volumes and densities measured/calculated in this study are internally consistent and reasonably accurate. 
Figure 5-8. Calculated and Measured Weights of Solids in Concentrates.

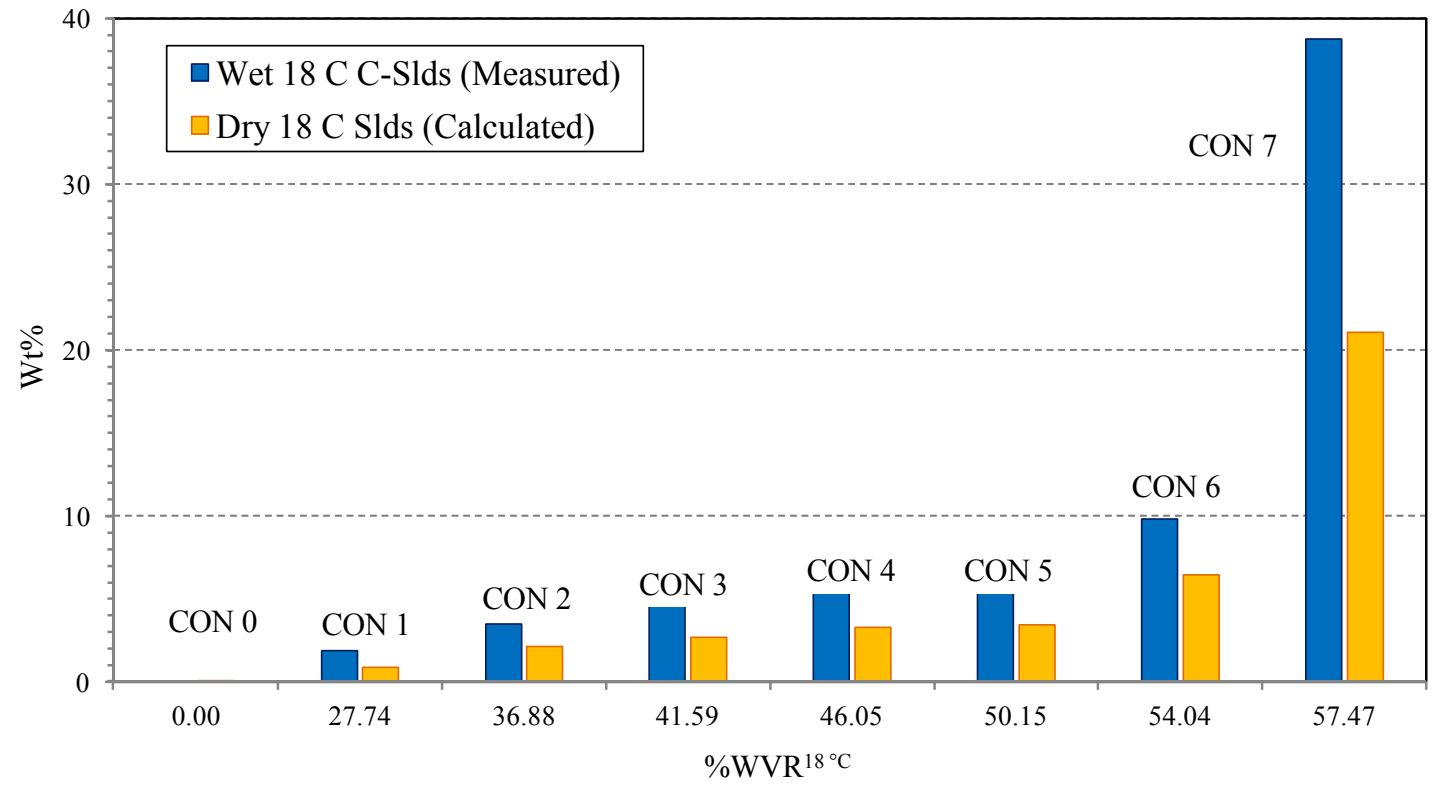

\subsection{COMPOSITION OF BOILDOWN SOLIDS}

\subsubsection{Quantities of Species Remaining in Solution}

Concentrations of chemical species in the C-Liq fractions of the AP-107 test composite and the 10 boildown test samples were tabulated in Table 4-1. It is informative to reformat this data to show how the estimated quantities of species remaining in solution after the concentrates were cooled to $18^{\circ} \mathrm{C}$ changed with boildown progress.

The total weight of a species present in a pot concentrate is:

$$
\mathrm{Wt}_{\text {Species }}=\mathrm{Wt}_{\mathrm{In} \text { solution }}+\mathrm{Wt}_{\text {In precipitated solids }}
$$

From Eq. 3-1, $C R_{\text {Total }}=\mathrm{Vol}_{\text {Composite }} / \mathrm{Vol}_{\text {Pot Concentrate. }}$ The total weight of a species present in a pot concentrate is, therefore:

$$
\mathrm{Wt}_{\text {Species }}=\left[(\mathrm{g} / \mathrm{L})_{\mathrm{C}-\mathrm{Liq}} \times\left(0.4737 \mathrm{~L} / C R^{18^{\circ} \mathrm{C}}\right) \times f_{\mathrm{Liq}}\right]+\left[(\mathrm{g} / \mathrm{L})_{\mathrm{C}-\text { Slds }} \times\left(0.4737 \mathrm{~L} / C R^{18^{\circ} \mathrm{C}}\right) \times f_{\text {Slds }}\right]
$$

where $f_{\text {Liq }}$ and $f_{\text {Slds }}$ are the volume fractions of liquid and solids in the concentrate.

If a species is not removed from the liquid phase by precipitation (or volatilization) during a boildown, the total weight of the species in a pot concentrate reduces to

$$
\mathrm{Wt}_{\text {Species }}=\mathrm{Wt}_{\text {In Solution }}=(\mathrm{g} / \mathrm{L})_{\mathrm{C}-\mathrm{Liq}} \times\left(0.4737 \mathrm{~L} / C R^{18^{\circ} \mathrm{C}}\right) \times f_{\text {Liq }}
$$

These values are displayed for the boildown samples in Figure 5-9(a)-(r). The 'Constant Wt' line in each plot shows the weight of the species that was present in the 473.7-mL charge of 
AP-107 composite added to the pot at the beginning of the boildown test. As previously noted, values for the test composite (CON 0$)$ and the volume reduction sequence samples (CON 1 to CON 7) are displayed with solid data markers; values for the dilution sequence samples (DIL 1 to DIL 3) are displayed with hollow data markers of the same shape. Plots for the species are presented in decreasing order of their estimated contribution (by weight) to solids present in the $54.04 \% \mathrm{WVR}^{18^{\circ} \mathrm{C}}(\mathrm{CON} 6)$ concentrate. Plots for priority analytes bromide and $\mathrm{Ca}$ are not included because no analytical results exceeded reported detection limits for any of the boildown liquid samples. Plots for priority analytes $\mathrm{P}$ and $\mathrm{S}$ displayed essentially the same trends as those for phosphate and sulfate and have also been omitted.

If a species is not removed from the liquid phase by precipitation (or volatilization) during a boildown, the calculated weights for all the samples should plot on or near the Constant Wt line. If a species is removed from solution by precipitation, species weights calculated using Equation 5-10 should fall below the Constant Wt line for some or all of the boildown samples.

Use of a reasonably accurate value of $f_{\text {Liq }}$ is of importance (particularly for highly concentrated species and/or when large quantities of solids are present). However, the C-Slds from the boildown samples were not analyzed and values for $f_{\text {Liq }}$ and $f_{\text {SIds }}$ were not directly measured. Values for $f_{\text {Liq }}$ were estimated using the same assumed composition of sample C-Slds - 50 vol\% solids and 50 vol\% interstitial liquid - used in previous calculations (Sections 5.1.3 and 5.3.3).

The errors associated with the displayed weights of species in solution combine analytical errors, errors in determination of $\% \mathrm{WVR}^{18^{\circ} \mathrm{C}}\left(C R^{18^{\circ} \mathrm{C}}\right)$ values, and errors in estimation of $f_{\text {Liq. }}$. The displayed values are, however, of sufficient accuracy to distinguish between changes due to removal/addition of water from/to the boildown pot and changes due to solids formation.

Reported minimum detection limit (MDL) values associated with each species have been converted to minimum detectable weight (MDW) values for each sample in the same manner used to calculate the weights in solution. The MDW values are displayed as small horizontal bars below each data point for the boildown samples.

Complementary to the weights of species in solution are the estimated weights of species in the solids in the $18{ }^{\circ} \mathrm{C}$ concentrates. These estimates can be calculated by subtracting the weights of a species remaining in solution from the total weight of the species in the initial composite (i.e., the Constant Wt value). The estimated weights of chemical species that would be found in precipitated solids if the pot concentrates from Steps CON 1, CON 4, CON 6, and CON 7 were cooled to $18{ }^{\circ} \mathrm{C}$ are displayed in Figure 5-10. (Small negative calculated weights are displayed with red data markers.) 
Figure 5-9. Weights of Species Remaining in Solution at $18^{\circ} \mathrm{C}$. (6 sheets)
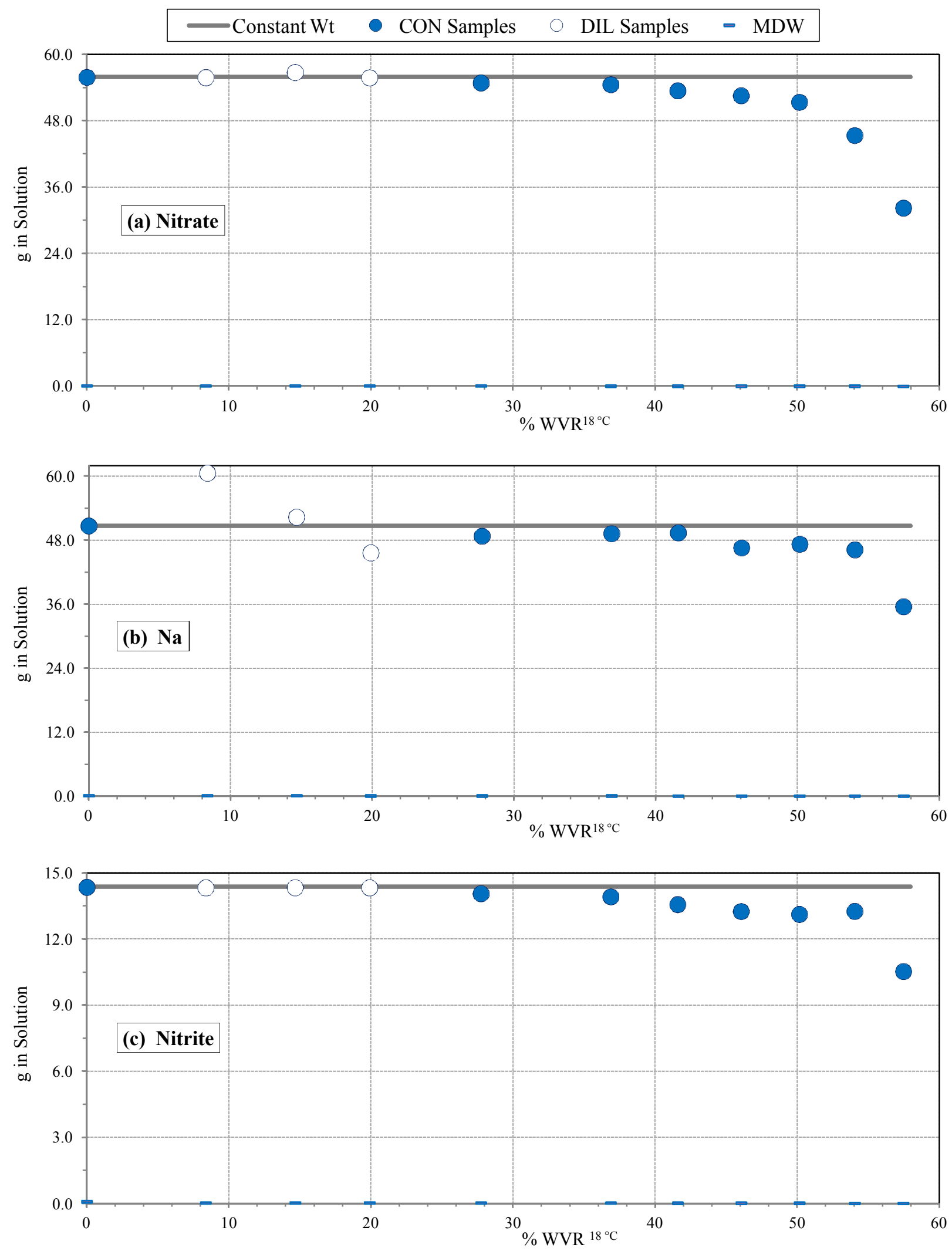
Figure 5-9. Weights of Species Remaining in Solution at $18^{\circ} \mathrm{C}$. (6 sheets)
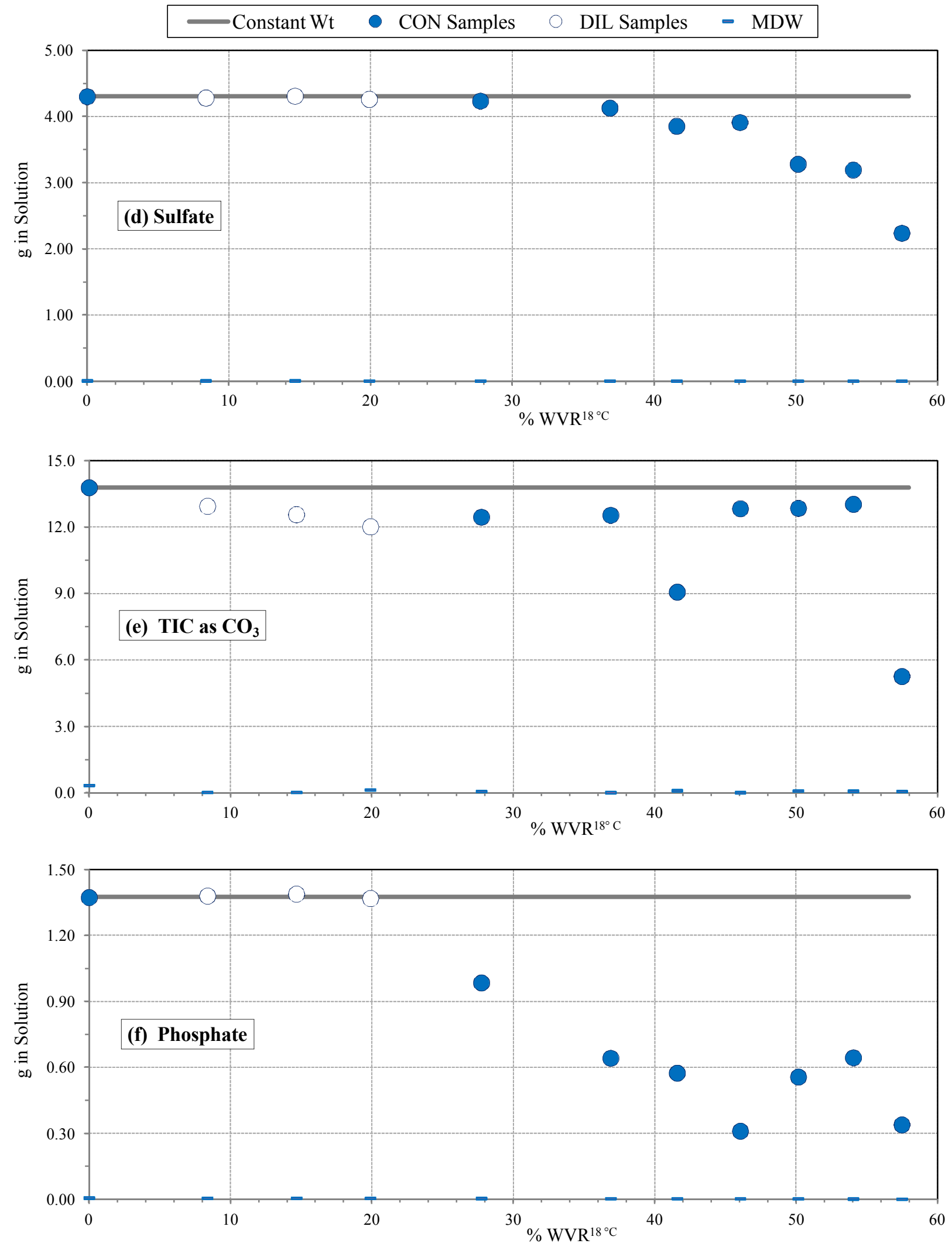
Figure 5-9. Weights of Species Remaining in Solution at $18^{\circ} \mathrm{C}$. (6 sheets)
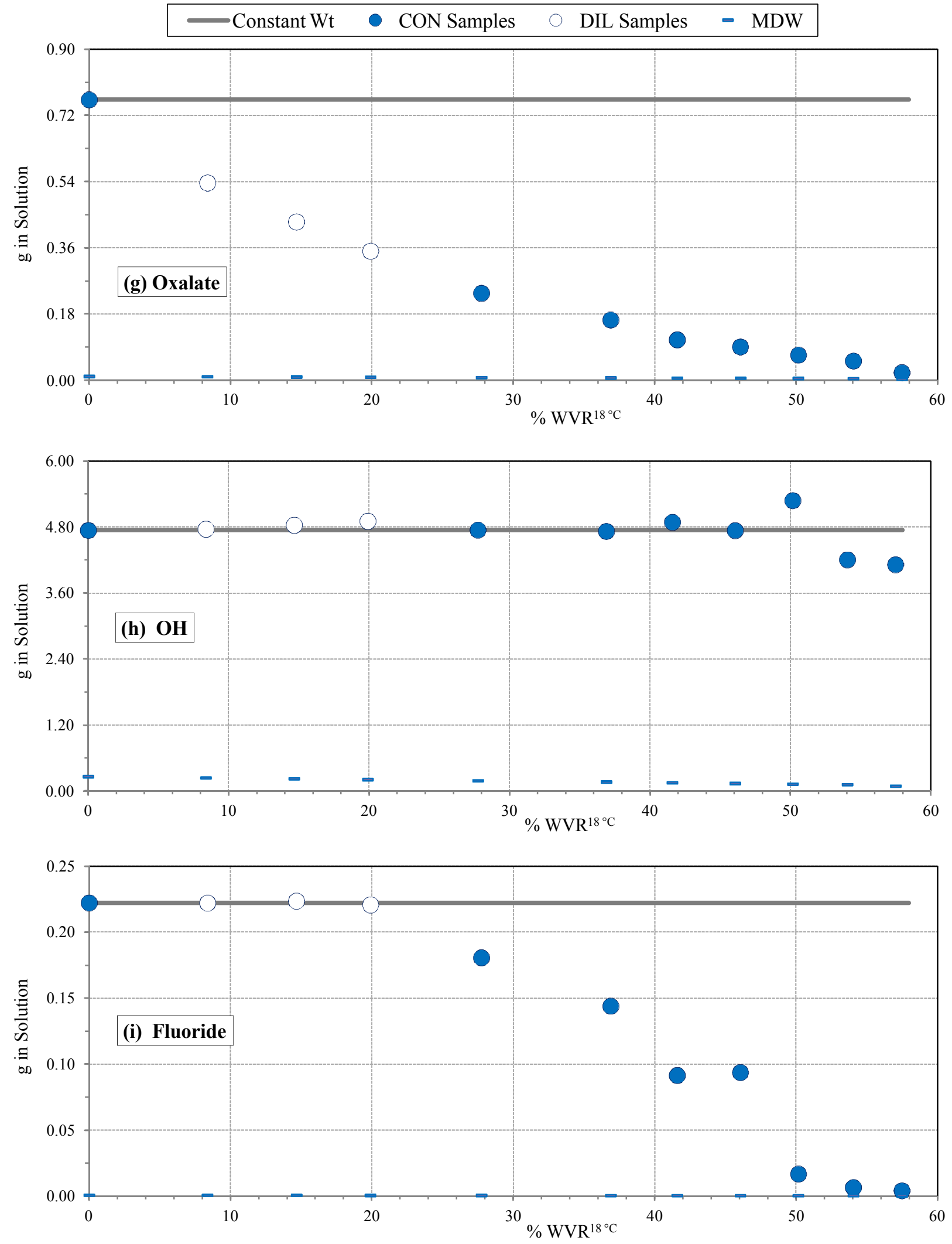
Figure 5-9. Weights of Species Remaining in Solution at $18^{\circ} \mathrm{C}$. (6 sheets)
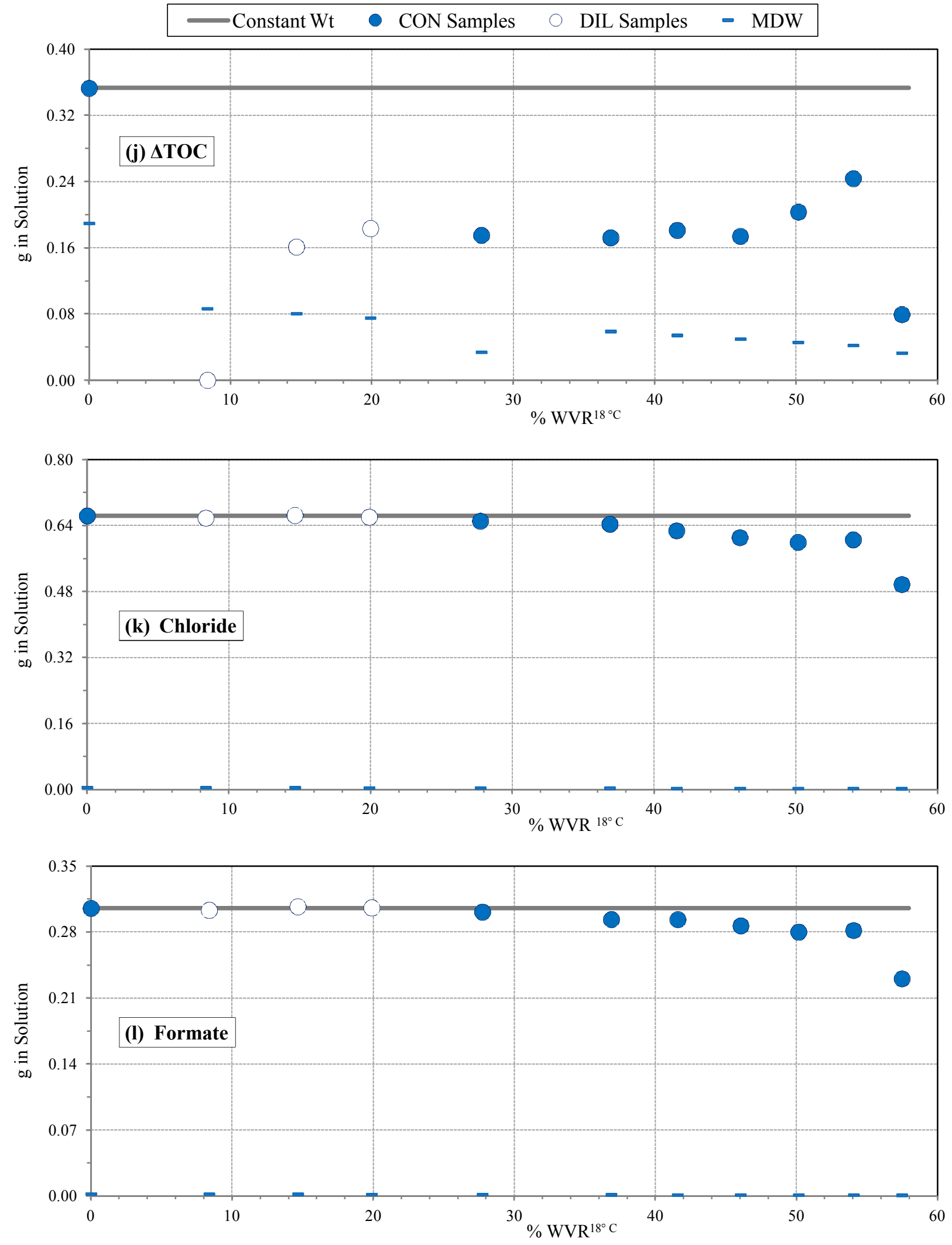
Figure 5-9. Weights of Species Remaining in Solution at $18^{\circ} \mathrm{C}$. (6 sheets)
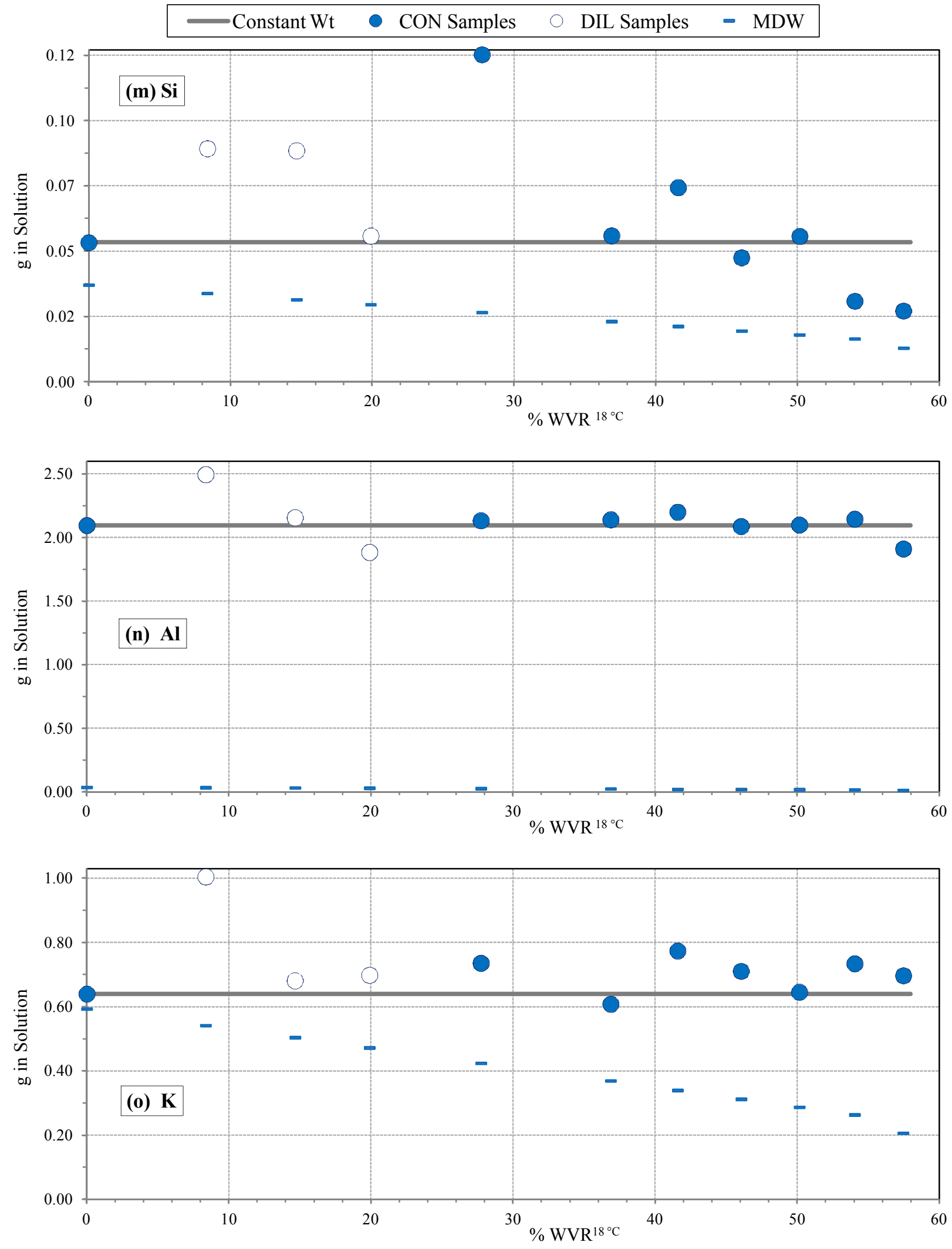
Figure 5-9. Weights of Species Remaining in Solution at $18{ }^{\circ} \mathrm{C}$. (6 sheets)
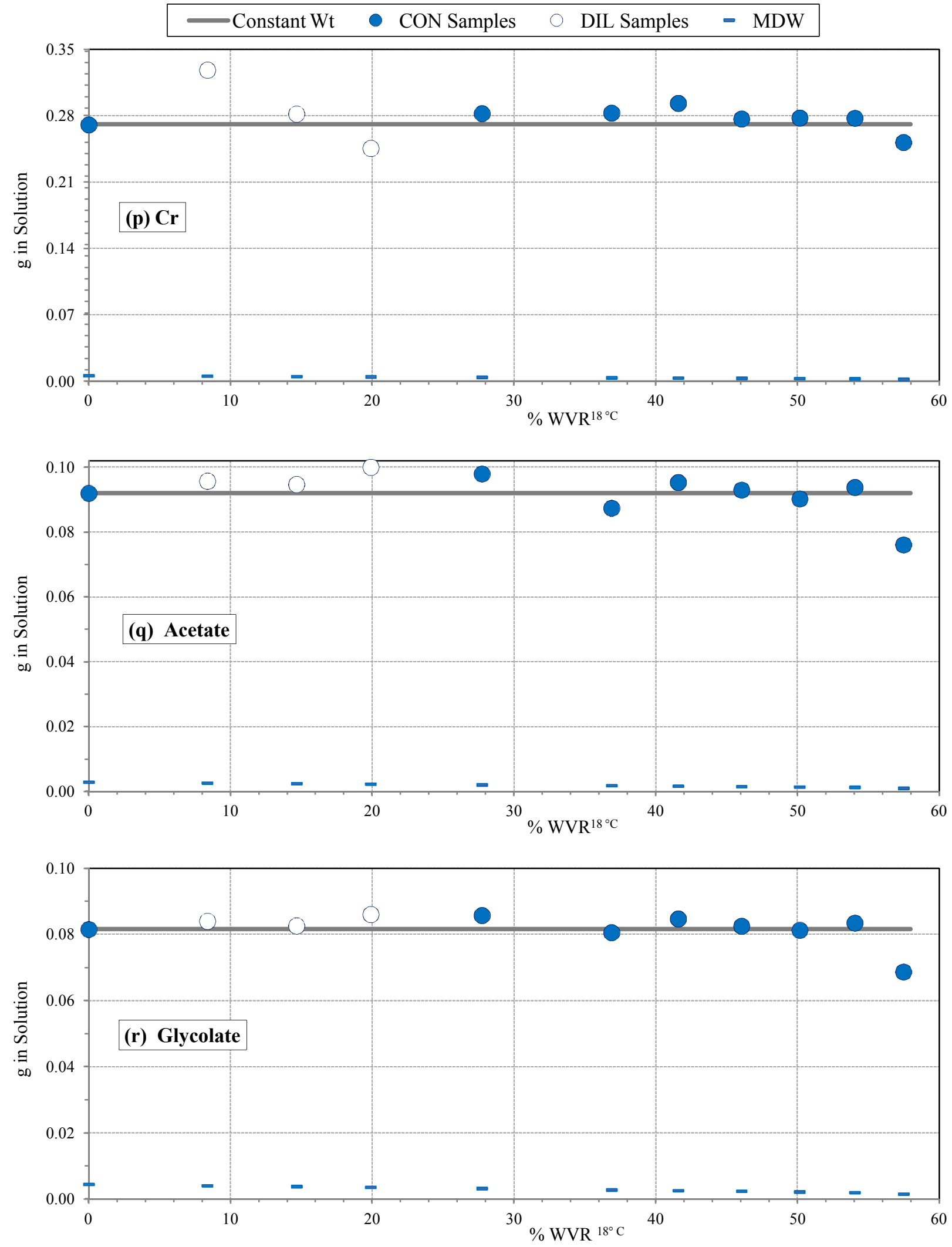
Figure 5-10. Estimated Weights of Species in $18^{\circ} \mathrm{C}$ Solids.
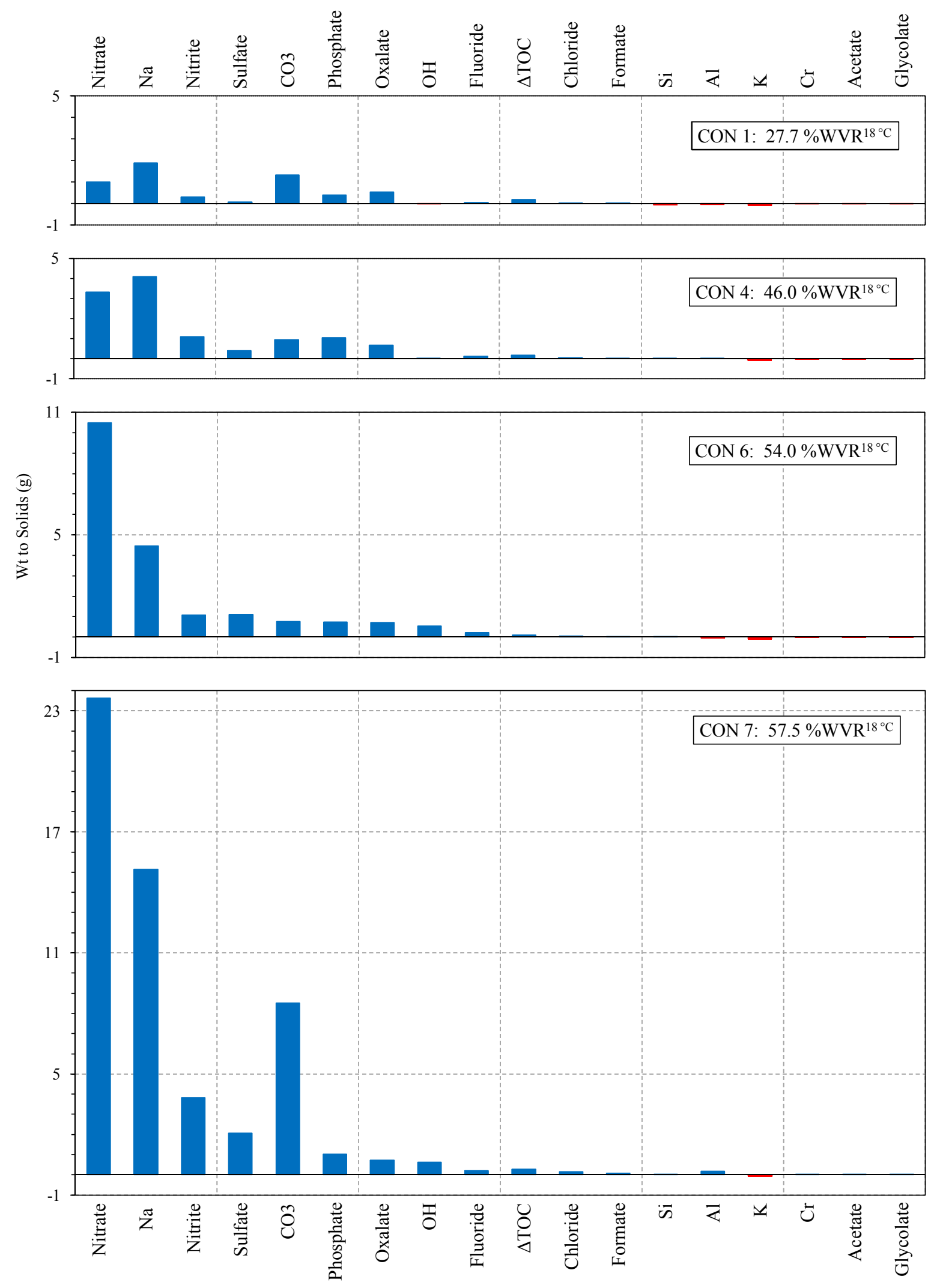
The chemical analysis data indicate that chloride, formate, $\mathrm{Si}, \mathrm{Al}, \mathrm{K}, \mathrm{Cr}$, acetate, and glycolate species do not contribute significantly to the solids formed in the boildown concentrates. The weights of $\mathrm{Si}$, acetate, and glycolate in the starting composite were $<1 \%$ of the estimated weight

of the solids formed in the $\mathrm{CON} 6\left(54.0 \% \mathrm{WVR}^{18^{\circ} \mathrm{C}}\right)$ concentrate. The estimated weights of chloride, formate, $\mathrm{Al}, \mathrm{K}, \mathrm{Cr}$, and $\triangle \mathrm{TOC}$ removed from solution were $<1 \%$ of the estimated weight of the CON 6 solids.

Though not definitive, the chemical analysis data suggests that some or all of the TOC in the starting composite not associated with analyzed organic acid anions ( $\triangle T O C)$ may have been volatilized and removed from the composite as a gas early in the volume reduction sequence.

\subsubsection{Solid Phase Characterization Results}

The 5 samples of C-Slds recovered from the AP-107 boildown samples (as identified in Table 3-2) were submitted to 222-S for SPC to identify solid phases present. Three methods were used: polarized light microscopy (PLM), powder X-ray diffraction (XRD), and scanning electron microscopy with energy-dispersive X-ray spectrometry (SEM/EDX). The SPC analyses were performed by members of the 222-S Special Analytical Services and Process Chemistry groups. Analysis results for the three SPC methods, including photographs and spectra, are presented in Attachment E.

The results of the SPC analyses are summarized in Table 5-4. The quantity descriptors are those used by the analysts in the method-specific reports.

Each of the SPC methods is limited to examination of very small quantities of solids. Homogenization and subsampling of radiologically "hot" samples to collect representative specimens of the required weight/volume is difficult at best. Nevertheless, the tabulated results in Table 5-4 are based on analysis of a single specimen for each method. Also, specimens for XRD and SEM/EDX analyses are dried during preparation, and solids dissolved in the liquids collected with the samples may precipitate and complicate interpretation of analysis results. For these reasons, the SPC analyses may identify solid phases that were not actually present in the boildown solids and/or may not identify solid phases that were present. The SPC results should certainly be taken to be qualitative in nature.

The solid phase composition of the first four samples, i.e., the C-Slds from the samples preceding and including the end-point slurry, represent the accumulating inventory of solids in the boildown pot during the volume reduction sequence. The final sample [Table 5-4(e)] shows the solid phases remaining after dilution of the the end-point slurry solids was complete. 
Table 5-4. Solid Phases Identified in C-Slds Samples. (2 sheets)

(a) S11T014140: Composite of C-Slds from Samples CON 1, CON 2, and CON $3\left(41.6 \% \mathrm{WVR}^{18^{\circ} \mathrm{C}}\right)$

\begin{tabular}{|c|c|c|c|c|}
\hline \multirow[b]{2}{*}{ Solid Phase } & \multirow[b]{2}{*}{ Formula } & \multicolumn{3}{|c|}{ Observations of Characterization Technique } \\
\hline & & XRD & SEM/EDX & PLM \\
\hline $\begin{array}{l}\text { Natroxalate } \\
\text { (sodium oxalate) }\end{array}$ & $\mathrm{Na}_{2} \mathrm{C}_{2} \mathrm{O}_{4}$ & Major & Major & Present \\
\hline $\begin{array}{l}\text { Natrophosphate } \\
\text { (sodium fluoride phosphate hydrate) }\end{array}$ & $\mathrm{Na}_{7} \mathrm{~F}\left(\mathrm{PO}_{4}\right)_{2} \cdot 19 \mathrm{H}_{2} \mathrm{O}$ & Major & Major & Present \\
\hline $\begin{array}{l}\text { Kogarkoite } \\
\text { (sodium fluoride sulfate) }\end{array}$ & $\mathrm{Na}_{3} \mathrm{FSO}_{4}$ & Minor & Moderate & - \\
\hline $\begin{array}{l}\text { Thermonatrite } \\
\text { (sodium carbonate monohydrate) }\end{array}$ & $\mathrm{Na}_{2} \mathrm{CO}_{3} \cdot \mathrm{H}_{2} \mathrm{O}$ & Minor & Minor & - \\
\hline Sodium nitrate & $\mathrm{NaNO}_{3}$ & Major $^{\text {a }}$ & - & - \\
\hline Sodium nitrite & $\mathrm{NaNO}_{2}$ & Minor $^{\mathrm{a}}$ & - & - \\
\hline
\end{tabular}

${ }^{\text {a }}$ Identified as a probable specimen preparation artifact where solids dissolved in the liquid collected with the sample precipitated upon drying.

(b) S11T014141: Composite of C-Slds from Samples CON 4 and CON $5\left(50.2 \% \mathrm{WVR}^{18^{\circ} \mathrm{C}}\right)$

\begin{tabular}{|l|l|c|c|c|}
\hline \multirow{2}{*}{\multicolumn{1}{c|}{ Solid Phase }} & \multirow{2}{*}{ Formula } & \multicolumn{2}{c|}{ Observations of Characterization Technique } \\
\cline { 3 - 5 } & \multicolumn{1}{c|}{ XRD } & \multicolumn{2}{c|}{ SEM/EDX } & PLM \\
\hline Natroxalate & $\mathrm{Na}_{2} \mathrm{C}_{2} \mathrm{O}_{4}$ & Trace & Moderate & Present \\
\hline Natrophosphate & $\mathrm{Na}_{7} \mathrm{~F}\left(\mathrm{PO}_{4}\right)_{2} \cdot 19 \mathrm{H}_{2} \mathrm{O}$ & Trace & Major & Present \\
\hline Kogarkoite & $\mathrm{Na}_{3} \mathrm{FSO}_{4}$ & - & Moderate & - \\
\hline Thermonatrite & $\mathrm{Na}_{2} \mathrm{CO}_{3} \cdot \mathrm{H}_{2} \mathrm{O}$ & Minor & Minor & - \\
\hline Sodium nitrate & $\mathrm{NaNO}_{3}$ & Major & \\
\hline Sodium nitrite & $\mathrm{NaNO}_{2}$ & Minor & & - \\
\hline
\end{tabular}

${ }^{\text {a }}$ Identified as a probable specimen preparation artifact where solids dissolved in the liquid collected with the sample precipitated upon drying.

(c) S11T014280: C-Slds from Sample CON $6\left(54.0 \% \mathrm{WVR}^{10^{\circ} \mathrm{C}}\right)$

\begin{tabular}{|c|c|c|c|c|}
\hline \multirow[b]{2}{*}{ Solid Phase } & \multirow[b]{2}{*}{ Formula } & \multicolumn{3}{|c|}{ Observations of Characterization Technique } \\
\hline & & XRD & SEM/EDX & PLM \\
\hline Natroxalate & $\mathrm{Na}_{2} \mathrm{C}_{2} \mathrm{O}_{4}$ & - & - & Present \\
\hline Natrophosphate & $\mathrm{Na}_{7} \mathrm{~F}\left(\mathrm{PO}_{4}\right)_{2} \cdot 19 \mathrm{H}_{2} \mathrm{O}$ & Minor & Major & Present \\
\hline Kogarkoite & $\mathrm{Na}_{3} \mathrm{FSO}_{4}$ & - & Moderate & - \\
\hline Thermonatrite & $\mathrm{Na}_{2} \mathrm{CO}_{3} \cdot \mathrm{H}_{2} \mathrm{O}$ & Minor & - & - \\
\hline Sodium nitrate & $\mathrm{NaNO}_{3}$ & Major $^{a}$ & Minor & Present \\
\hline Sodium nitrite & $\mathrm{NaNO}_{2}$ & Trace $^{\mathrm{a}}$ & - & - \\
\hline Sodium phosphate & $\mathrm{Na}_{3} \mathrm{PO}_{4} \cdot 12 \mathrm{H}_{2} \mathrm{O}$ & - & - & Present \\
\hline Sodium sulfate & $\mathrm{Na}_{2} \mathrm{SO}_{4}{ }^{\mathrm{b}}$ & - & Present & - \\
\hline
\end{tabular}

${ }^{a}$ Identified as a probable specimen preparation artifact where solids dissolved in the liquid collected with the sample precipitated upon drying.

${ }^{\mathrm{b}}$ A sodium sulfate solid phase with this specific composition was not identified. 
Table 5-4. Solid Phases Identified in C-SIds Samples. (2 sheets)

(d) S11T011074: C-Slds from end-point slurry (Sample CON 7 at $57.5 \% \mathrm{WVR}^{18^{\circ} \mathrm{C}}$ )

\begin{tabular}{|c|c|c|c|c|}
\hline \multirow[b]{2}{*}{ Solid Phase } & \multirow[b]{2}{*}{ Formula } & \multicolumn{3}{|c|}{ Observations of Characterization Technique } \\
\hline & & XRD & SEM/EDX & PLM \\
\hline Natroxalate & $\mathrm{Na}_{2} \mathrm{C}_{2} \mathrm{O}_{4}$ & - & - & Mostly \\
\hline Natrophosphate & $\mathrm{Na}_{7} \mathrm{~F}\left(\mathrm{PO}_{4}\right)_{2} \cdot 19 \mathrm{H}_{2} \mathrm{O}$ & Trace & Major & Some \\
\hline Kogarkoite & $\mathrm{Na}_{3} \mathrm{FSO}_{4}$ & - & Moderate & - \\
\hline Thermonatrite & $\mathrm{Na}_{2} \mathrm{CO}_{3} \cdot \mathrm{H}_{2} \mathrm{O}$ & Minor & Moderate & Some \\
\hline Sodium nitrate & $\mathrm{NaNO}_{3}$ & Major $^{\mathrm{a}}$ & Major & - \\
\hline Sodium nitrite & $\mathrm{NaNO}_{2}{ }^{\mathrm{a}}$ & Minor $^{\mathrm{a}}$ & - & - \\
\hline Sodium phosphate & $\mathrm{Na}_{3} \mathrm{PO}_{4} \cdot 12 \mathrm{H}_{2} \mathrm{O}$ & - & - & - \\
\hline Sodium sulfate & $\mathrm{Na}_{2} \mathrm{SO}_{4}{ }^{\mathrm{b}}$ & - & - & - \\
\hline Unidentified solids & - & - & - & Minor $^{c}$ \\
\hline
\end{tabular}

${ }^{a}$ Identified as a probable specimen preparation artifact where solids dissolved in the liquid collected with the sample precipitated upon drying.

${ }^{\mathrm{b}}$ A sodium sulfate solid phase with this specific composition was not identified.

${ }^{\mathrm{c}}$ Light-brown, fine-grained material.

(e) S11T011075: Solids remaining after dilution of end-point slurry to $8.4 \% \mathrm{WVR}^{1{ }^{\circ} \mathrm{C}}$ (Sample DIL 3)

\begin{tabular}{|l|l|c|c|c|}
\hline \multirow{2}{*}{ Solid Phase } & \multirow{2}{*}{ Formula } & \multicolumn{2}{c|}{ Observations of Characterization Technique } \\
\cline { 3 - 5 } & & XRD & SEM/EDX & PLM \\
\hline Natroxalate & $\mathrm{Na}_{2} \mathrm{C}_{2} \mathrm{O}_{4}$ & Major & Major & Present \\
\hline Natrophosphate & $\mathrm{Na}_{7} \mathrm{~F}\left(\mathrm{PO}_{4}\right)_{2} \cdot 19 \mathrm{H}_{2} \mathrm{O}$ & Minor & - & - \\
\hline Kogarkoite & $\mathrm{Na}_{3} \mathrm{FSO}_{4}$ & - & - & - \\
\hline Thermonatrite & $\mathrm{Na}_{2} \mathrm{CO}_{3} \cdot \mathrm{H}_{2} \mathrm{O}$ & Trace & Trace & - \\
\hline Sodium nitrate & $\mathrm{NaNO}_{3}$ & Major ${ }^{\mathrm{a}}$ & - & - \\
\hline Sodium nitrite & $\mathrm{NaNO}_{2}$ & Minor ${ }^{\mathrm{a}}$ & - & - \\
\hline Sodium phosphate & $\mathrm{Na}_{3} \mathrm{PO}_{4} \cdot 12 \mathrm{H}_{2} \mathrm{O}$ & - & - & - \\
\hline Sodium sulfate & $\mathrm{Na}_{2} \mathrm{SO}_{4}{ }^{\mathrm{b}}$ & - & - & - \\
\hline $\begin{array}{l}\text { Natrite } \\
\text { (sodium carbonate) }\end{array}$ & $\mathrm{Na}_{2} \mathrm{CO}_{3}$ & Minor & Trace & - \\
\hline
\end{tabular}

${ }^{a}$ Identified as a probable specimen preparation artifact where solids dissolved in the liquid collected with the sample precipitated upon drying.

${ }^{\mathrm{b}}$ A sodium sulfate solid phase with this specific composition was not identified. 


\subsubsection{Solid Phases Present in Concentrate Solids}

In Figure 5-11, the chemical analysis data of Section 5.4.1 and the SPC results of Section 5.4.2 are combined. The chemical analysis and SPC results are somewhat inconsistent in their predictions of the composition of the solids formed in the boildown concentrates, and the data displayed in Figure 5-11 should be treated as semiquantitative in nature.

The estimated weights of the chemical species in the solid fractions of the $18{ }^{\circ} \mathrm{C}$ concentrates (displayed in Figure 5-10) were first converted to weights of solid phases identified in SPC analysis or assigned as proxies. (For example, $\mathrm{Na}_{2} \mathrm{SO}_{4}$ was used as proxy phase for Na-sulfate solids even though this specific phase was not identified in samples of the boildown solids.) The weights of the solid phases were then adjusted so the sums of the phase weights for each boildown step were equal to the estimated dry solids weights calculated in Section 5.3.3.

The adjusted phase weights were then converted to solid phase volumes by dividing by the reference densities of the solid phases. Finally, the solid phase volumes were converted to vol\% values by dividing by the sum of the volumes of the solid phases estimated to be present in the CON $6\left(54.04 \% \mathrm{WVR}^{18^{\circ} \mathrm{C}}\right)$ concentrate.

In general, the AP-107 boildown testing indicates that given sufficient time/nucleation sites, sodium oxalate will form in cooled $\leq 8-\%$ WVR concentrates. The chemical analysis data also suggest that a small amount of carbonate solids precipitate from the cooled $<15-\% \mathrm{WVR}$ concentrates.

In cooled $<46-\%$ WVR concentrates most of the oxalate in the feed composite precipitates as sodium oxalate while the relative quantity of the sodium carbonate formed early in the volume reduction is unchanged. At this level of volume reduction $\approx 80 \%$ of the phosphate, $\approx 20 \%$ of the sulfate, and $\approx 75 \%$ of the fluoride in the initial composite precipitates from a cooled concentrate as the sodium fluoride double salts natrophosphate $\left[\mathrm{Na}_{7} \mathrm{~F}\left(\mathrm{PO}_{4}\right)_{2} \cdot 19 \mathrm{H}_{2} \mathrm{O}\right]$ and kogarkoite $\left(\mathrm{Na}_{3} \mathrm{FSO}_{4}\right)$.

As the volume reduction progresses beyond $46 \% \mathrm{WVR}$, the phosphate in solution actually begins to increase. Phosphate is the only species that displays an increase in solution concentration after significant volume reduction. It is proposed that beyond $\approx 46 \% \mathrm{WVR}$, natrophosphate begins to redissolve in the concentrates due to reduced solution concentrations of sodium, fluoride, and water. Most of the released fluoride is recaptured as additional kogarkoite.

At $54 \%$ WVR nearly all the oxalate and fluoride in the initial feed composite precipitates from a cooled concentrate as sodium oxalate, natrophosphate, and kogarkoite. There is insufficient fluoride in the initial feed composite to form only the sodium fluoride double salts with the available phosphate and sulfate. Portions of the phosphate and sulfate remaining in solution after the fluoride has been exhausted precipitate as sodium phosphate and sodium sulfate salts. 
LAB-RPT-12-00008, R0

Figure 5-11. Estimated Vol\% of Solid Phases in Concentrate Solids.
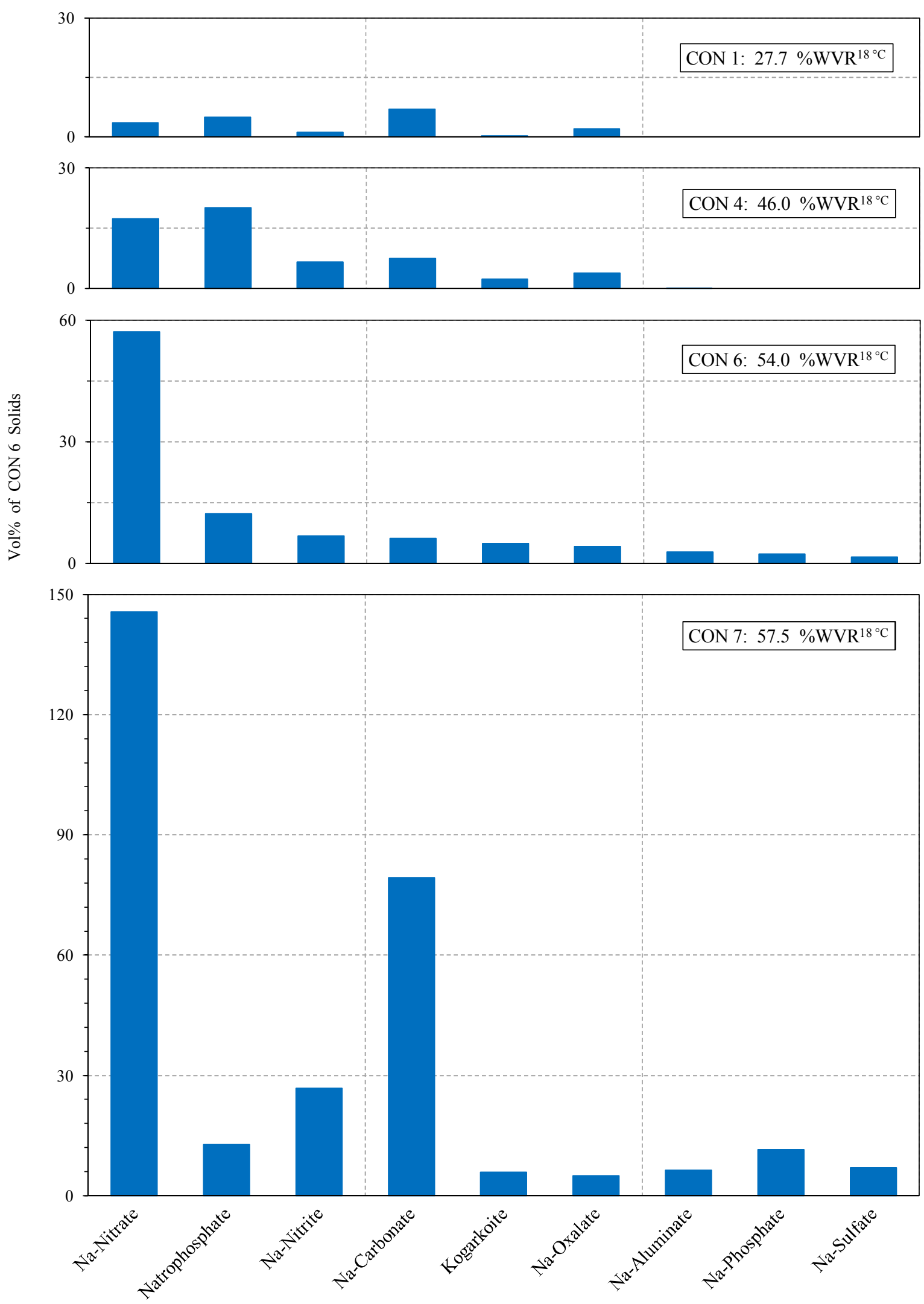
As the volume reduction exceeds $54 \% \mathrm{WVR}$, significant quantities of sodium nitrate and sodium carbonate precipitate from a cooled concentrate and become the major components of the solid precipitates.

Nitrate, nitrite, and TIC (as $\mathrm{CO}_{3}$ ) were, by far, the most concentrated anionic species in the initial feed composite, and relatively small analytical and/or computational errors could result in significant errors in estimation of their relative contributions to solids formed in cooled boildown concentrates. While the contributions of the solid phases containing these species may be somewhat overestimated (particularly in solids from cooled concentrates produced early in the boildown volume reduction), the analytical data clearly indicate that precipitation of sodium nitrate, sodium carbonate, and sodium nitrite is the major cause of the dramatic increase in the quantity of solids in the concentrate after volume reduction of the AP-107 feed composite progressed beyond $54 \% \mathrm{WVR}$. 


\subsection{QUALITY ASSURANCE}

\subsection{HOT CELLS OPERATIONS}

As discussed in Section 2.2, temperature measurements recorded during the hot cells boildown operations were corrected to true readings provided by a certified Pt-RTD. The resistance thermometer was calibrated using equipment which can be traced back to established national standards, e.g. the National Institute of Standards and Technology (NIST). The Certificate of Calibration for this reference thermometer was issued May 10, 2011, and was valid for 1 year. A copy of the calibration certificate is included in the project file.

Pressure measurements in the hot cells operations were indirectly calibrated through the verified temperature readings. The measured pressures over pure water boiling at measured temperatures were compared with tabulated vapor pressures of pure water at the same temperatures.

The in-tolerance status of each analytical balance used during the boildown study was verified at a minimum of before use or daily, whichever was less frequent (ATS-LO-140-008, "222-S Laboratory Routine Use and Quality Assurance for Analytical Balances at 222-S Laboratory Complex"). The calibration verification measurements were recorded on Balance Calibration Verification Check Sheets. Copies of the check sheets are included in the project file.

\subsection{LABORATORY ANALYSES}

Quality control measurements required to ensure the quality of the analyses of the boildown samples performed at 222-S are specified in ATS-MP-1032, 222-S Laboratory Quality Assurance Plan, and in ATL-MP-1011, ATL Quality Assurance Project Plan for 222-S Laboratory. The results of all quality control measurements performed are included in the transcript of the analytical results presented in Attachment D.

\subsection{DEVIATIONS FROM TEST PLAN}

The AP-107 boildown study was executed, in general, as described in the client-approved laboratory test plan (LAB-PLN-10-00007). The test plan incorporated some minor deviations from the guidance for completion of the boildown study provided in the TSAP

(RPP-PLAN-40837); these changes were executed with the concurrence of the 242-A Evaporator Technical Point of Contact. 
LAB-RPT-12-00008, R0

\subsection{REFERENCES}

ARCHO 1974, "Densities of Caustic Waste Solutions as a Function of Temperature," (Internal memorandum MEM-052174 from J. S. Buckingham to H. F. Jensen, May 21), Atlantic Richfield Hanford Company, Richland, Washington.

ATL-MP-1011, ATL Quality Assurance Project Plan for 222-S Laboratory, Rev. 9, Advanced Technologies and Laboratories International, Inc., Richland, Washington.

ATS-LO-140-008, "222-S Laboratory Routine Use and Quality Assurance for Analytical Balances at 222-S Laboratory Complex," Rev. I-0, Washington River Protection Solutions LLC, Richland, Washington.

ATS-LT-519-183, "222-S Laboratory Determination of Properties of Radiological Solutions as a Function of Volume Reduction at Reduced Pressure," Rev. F-0, Washington River Protection Solutions LLC, Richland, Washington.

ATS-MP-1032, 222-S Laboratory Quality Assurance Plan, Rev. 4, Washington River Protection Solutions LLC, Richland, Washington.

LAB-PLN-10-00007, 2010, Test Plan for Boildown Study on Supernate Retrieved from 241-AP-107 in May 2010, Washington River Protection Solutions LLC, Richland, Washington.

RPP-PLAN-40837, 2009, Tank 241-AP-107 Grab Sampling and Analysis Plan in Support of Evaporator Campaign for Fiscal Year 2010, Rev. 1, Washington River Protection Solutions LLC, Richland, Washington.

RPP-RPT-47358, 2011, Final Report for Tank 241-AP-107 Liquid Grab Samples in Support of the Evaporator Program, Rev. 1, prepared for Washington River Protection Solutions LLC by ATL International, Inc., Richland, Washington.

WRPS-0900372, 2009, Results of Lifetime Testing of Anton Paar DMA 35N Portable Density Meter (Internal memorandum from W. S. Callaway to C. M. Seidel, March 23), Washington River Protection Solutions LLC, Richland, Washington. 
LAB-RPT-12-00008, R0

ATTACHMENT A

VOLUME CALIBRATION OF CENTRIFUGE CONES 


\section{ATTACHMENT A VOLUME CALIBRATIONS OF CENTRIFUGE CONES}

The volumes read ( $\left.\mathrm{Vol}_{\text {Read }}\right)$ from graduations on the $15-\mathrm{mL}$ centrifuge cones used to collect the boildown samples were adjusted to corrected values ( Vol $\left._{\text {Corrected }}\right)$. The gravimetric data collected and calculations performed in deriving the correction functions are presented in Table A-1.

Table A-1. Centrifuge Cone Volume Calibrations. (6 sheets)

\begin{tabular}{|c|c|c|c|c|c|c|c|}
\hline \multirow{3}{*}{ Cone ID } & \multirow{3}{*}{ Cal Date } & \multirow{2}{*}{\multicolumn{2}{|c|}{$\mathrm{H}_{2} \mathrm{O}$}} & \multirow{2}{*}{$\begin{array}{r}\text { Cone Mark } \\
\mathrm{Wt} \mathrm{H}_{2} \mathrm{O} \text { Added } \\
\end{array}$} & \multicolumn{3}{|c|}{$=$ Volume Mark on Cone $(\mathrm{mL})$} \\
\hline & & & & & \multicolumn{3}{|c|}{$=\mathrm{Wt} \mathrm{H}_{2} \mathrm{O}$ Added to Cone $(\mathrm{g})$} \\
\hline & & $\mathrm{T}\left({ }^{\circ} \mathrm{C}\right)$ & $\mathrm{D}(\mathrm{g} / \mathrm{mL})$ & Vol $\mathrm{H}_{2} \mathrm{O}$ Added & \multicolumn{3}{|c|}{$=\mathrm{Wt} \mathrm{H}_{2} \mathrm{O}(\mathrm{g}) / \mathrm{D} \mathrm{H}_{2} \mathrm{O}(\mathrm{g} / \mathrm{mL})$} \\
\hline \multirow{18}{*}{$\begin{array}{l}\text { AP-107 } \\
\text { BLDN } \\
\text { Cone 1 }\end{array}$} & \multirow{3}{*}{$07 / 25 / 11$} & \multirow{3}{*}{22.5} & \multirow{3}{*}{0.99766} & Cone Mark & 10.0 & $11.5^{*}$ & 13.0 \\
\hline & & & & Wt $\mathrm{H}_{2} \mathrm{O}$ Added $(\mathrm{g})$ & 9.9940 & $11.3624^{*}$ & 12.8902 \\
\hline & & & & Vol $\mathrm{H}_{2} \mathrm{O}(\mathrm{mL})$ & 10.0175 & $11.3891^{*}$ & 12.9205 \\
\hline & \multirow{3}{*}{$07 / 25 / 11$} & \multirow{3}{*}{22.5} & \multirow{3}{*}{0.99766} & Cone Mark & 10.0 & 11.5 & 13.0 \\
\hline & & & & Wt $\mathrm{H}_{2} \mathrm{O}$ Added $(\mathrm{g})$ & 9.9774 & 11.4073 & 12.8693 \\
\hline & & & & $\mathrm{Vol} \mathrm{H} \mathrm{H}_{2} \mathrm{O}(\mathrm{mL})$ & 10.0008 & 11.4341 & 12.8995 \\
\hline & \multirow{3}{*}{$07 / 25 / 11$} & \multirow{3}{*}{22.5} & \multirow{3}{*}{0.99766} & Cone Mark & 10.0 & 11.5 & 13.0 \\
\hline & & & & Wt $\mathrm{H}_{2} \mathrm{O}$ Added $(\mathrm{g})$ & 9.9661 & 11.4437 & 12.9021 \\
\hline & & & & $\mathrm{Vol} \mathrm{H}_{2} \mathrm{O}(\mathrm{mL})$ & 9.9895 & 11.4706 & 12.9324 \\
\hline & \multirow{3}{*}{$07 / 27 / 11$} & \multirow{3}{*}{22.9} & \multirow{3}{*}{0.99756} & Cone Mark & 10.0 & 11.5 & 13.0 \\
\hline & & & & Wt $\mathrm{H}_{2} \mathrm{O}$ Added (g) & 9.9574 & 11.4301 & 12.9225 \\
\hline & & & & $\mathrm{Vol} \mathrm{H} \mathrm{H}_{2} \mathrm{O}(\mathrm{mL})$ & 9.9817 & 11.4580 & 12.9541 \\
\hline & \multirow{3}{*}{$07 / 27 / 11$} & \multirow{3}{*}{22.9} & \multirow{3}{*}{0.99756} & Cone Mark & 10.0 & 11.5 & 13.0 \\
\hline & & & & Wt $\mathrm{H}_{2} \mathrm{O}$ Added $(\mathrm{g})$ & 9.9351 & 11.4089 & 12.9062 \\
\hline & & & & $\mathrm{Vol} \mathrm{H}_{2} \mathrm{O}(\mathrm{mL})$ & 9.9594 & 11.4368 & 12.9377 \\
\hline & \multirow{3}{*}{$07 / 27 / 11$} & \multirow{3}{*}{22.9} & \multirow{3}{*}{0.99756} & Cone Mark & 10.0 & 11.5 & 13.0 \\
\hline & & & & Wt $\mathrm{H}_{2} \mathrm{O}$ Added (g) & 9.9844 & 11.4330 & 12.9027 \\
\hline & & & & $\mathrm{Vol} \mathrm{H}_{2} \mathrm{O}(\mathrm{mL})$ & 10.0088 & 11.4609 & 12.9342 \\
\hline \multicolumn{4}{|c|}{ Cone 1 - Sample CON 0B } & \multicolumn{4}{|c|}{$\mathrm{Vol}_{\text {Corrected }}=\left(0.9789 \times \mathrm{Vol}_{\text {Read }}\right)+0.2009$} \\
\hline
\end{tabular}

$\mathrm{D}=$ density

$\mathrm{T}=$ temperature

* Outlier: not used in formulation of the calibration equation. 
LAB-RPT-12-00008, R0

Table A-1. Centrifuge Cone Volume Calibrations. (6 sheets)

\begin{tabular}{|c|c|c|c|c|c|c|c|}
\hline \multirow{3}{*}{ Cone ID } & \multirow{3}{*}{ Cal Date } & \multirow{2}{*}{\multicolumn{2}{|c|}{$\mathrm{H}_{2} \mathrm{O}$}} & \multirow{2}{*}{$\begin{array}{r}\text { Cone Mark } \\
\mathrm{Wt} \mathrm{H}_{2} \mathrm{O} \text { Added }\end{array}$} & \multicolumn{3}{|c|}{$=$ Volume Mark on Cone $(\mathrm{mL})$} \\
\hline & & & & & \multicolumn{3}{|c|}{$=\mathrm{Wt} \mathrm{H}_{2} \mathrm{O}$ Added to Cone $(\mathrm{g})$} \\
\hline & & $\mathrm{T}\left({ }^{\circ} \mathrm{C}\right)$ & $\mathrm{D}(\mathrm{g} / \mathrm{mL})$ & Vol $\mathrm{H}_{2} \mathrm{O}$ Added & \multicolumn{3}{|c|}{$=\mathrm{Wt} \mathrm{H}_{2} \mathrm{O}(\mathrm{g}) / \mathrm{D} \mathrm{H}_{2} \mathrm{O}(\mathrm{g} / \mathrm{mL})$} \\
\hline \multirow{9}{*}{$\begin{array}{l}\text { AP-107 } \\
\text { BLDN } \\
\text { Cone } 2\end{array}$} & \multirow{3}{*}{$07 / 25 / 11$} & \multirow{3}{*}{22.5} & \multirow{3}{*}{0.99766} & Cone Mark & 10.0 & 11.5 & 13.0 \\
\hline & & & & Wt $\mathrm{H}_{2} \mathrm{O}$ Added (g) & 10.0414 & 11.4710 & 12.9498 \\
\hline & & & & $\mathrm{Vol} \mathrm{H}_{2} \mathrm{O}(\mathrm{mL})$ & 10.0650 & 11.4979 & 12.9802 \\
\hline & \multirow{3}{*}{$07 / 25 / 11$} & \multirow{3}{*}{22.5} & \multirow{3}{*}{0.99766} & Cone Mark & 10.0 & 11.5 & 13.0 \\
\hline & & & & Wt $\mathrm{H}_{2} \mathrm{O}$ Added (g) & 10.0206 & 11.4863 & 12.9615 \\
\hline & & & & $\mathrm{Vol} \mathrm{H}_{2} \mathrm{O}(\mathrm{mL})$ & 10.0441 & 11.5133 & 12.9919 \\
\hline & \multirow{3}{*}{$07 / 25 / 11$} & \multirow{3}{*}{22.5} & \multirow{3}{*}{0.99766} & Cone Mark & 10.0 & 11.5 & 13.0 \\
\hline & & & & Wt $\mathrm{H}_{2} \mathrm{O}$ Added (g) & 10.0291 & 11.4762 & 12.9468 \\
\hline & & & & $\mathrm{Vol} \mathrm{H} \mathrm{H}_{2} \mathrm{O}(\mathrm{mL})$ & 10.0526 & 11.5031 & 12.9772 \\
\hline \multicolumn{4}{|c|}{ Cone 2 - Sample CON 1} & \multicolumn{4}{|c|}{$\mathrm{Vol}_{\text {Corrected }}=\left(0.9764 \times \mathrm{Vol}_{\text {Read }}\right)+0.2857$} \\
\hline
\end{tabular}

\begin{tabular}{|c|c|c|c|c|c|c|c|}
\hline \multirow{3}{*}{ Cone ID } & \multirow{3}{*}{ Cal Date } & \multirow{2}{*}{\multicolumn{2}{|c|}{$\mathrm{H}_{2} \mathrm{O}$}} & \multirow{2}{*}{$\begin{array}{r}\text { Cone Mark } \\
\text { Wt } \mathrm{H}_{2} \mathrm{O} \text { Added } \\
\end{array}$} & \multicolumn{3}{|c|}{$=$ Volume Mark on Cone $(\mathrm{mL})$} \\
\hline & & & & & \multicolumn{3}{|c|}{$=\mathrm{Wt}_{2} \mathrm{O}$ Added to Cone $(\mathrm{g})$} \\
\hline & & $\mathrm{T}\left({ }^{\circ} \mathrm{C}\right)$ & $\mathrm{D}(\mathrm{g} / \mathrm{mL})$ & $\mathrm{Vol} \mathrm{H}_{2} \mathrm{O}$ Added & \multicolumn{3}{|c|}{$=\mathrm{Wt} \mathrm{H}_{2} \mathrm{O}(\mathrm{g}) / \mathrm{D} \mathrm{H}_{2} \mathrm{O}(\mathrm{g} / \mathrm{mL})$} \\
\hline \multirow{9}{*}{$\begin{array}{l}\text { AP-107 } \\
\text { BLDN } \\
\text { Cone } 3\end{array}$} & \multirow{3}{*}{$07 / 25 / 11$} & \multirow{3}{*}{22.2} & \multirow{3}{*}{0.99773} & Cone Mark & 10.0 & 11.5 & 13.0 \\
\hline & & & & Wt $\mathrm{H}_{2} \mathrm{O}$ Added (g) & 9.9056 & 11.3682 & 12.8385 \\
\hline & & & & $\mathrm{Vol} \mathrm{H}_{2} \mathrm{O}(\mathrm{mL})$ & 9.9282 & 11.3941 & 12.8678 \\
\hline & \multirow{3}{*}{$07 / 25 / 11$} & \multirow{3}{*}{22.3} & \multirow{3}{*}{0.99770} & Cone Mark & 10.0 & 11.5 & 13.0 \\
\hline & & & & Wt $\mathrm{H}_{2} \mathrm{O}$ Added $(\mathrm{g})$ & 9.8817 & 11.4072 & 12.8355 \\
\hline & & & & $\mathrm{Vol} \mathrm{H}_{2} \mathrm{O}(\mathrm{mL})$ & 9.9045 & 11.4335 & 12.8651 \\
\hline & \multirow{3}{*}{$07 / 25 / 11$} & \multirow{3}{*}{22.4} & \multirow{3}{*}{0.99768} & Cone Mark & 10.0 & 11.5 & 13.0 \\
\hline & & & & Wt $\mathrm{H}_{2} \mathrm{O}$ Added $(\mathrm{g})$ & 9.9485 & 11.3702 & 12.8204 \\
\hline & & & & $\mathrm{Vol} \mathrm{H}_{2} \mathrm{O}(\mathrm{mL})$ & 9.9716 & 11.3967 & 12.8502 \\
\hline \multicolumn{4}{|c|}{ Cone 3 - Sample CON 2} & \multicolumn{4}{|c|}{$\mathrm{Vol}_{\text {Corrected }}=\left(0.9754 \times \mathrm{Vol}_{\text {Read }}\right)+0.1840$} \\
\hline
\end{tabular}


LAB-RPT-12-00008, R0

Table A-1. Centrifuge Cone Volume Calibrations. (6 sheets)

\begin{tabular}{|c|c|c|c|c|c|c|c|}
\hline \multirow{3}{*}{ Cone ID } & \multirow{3}{*}{ Cal Date } & \multirow{2}{*}{\multicolumn{2}{|c|}{$\mathrm{H}_{2} \mathrm{O}$}} & \multirow{2}{*}{$\begin{array}{r}\text { Cone Mark } \\
\text { Wt } \mathrm{H}_{2} \mathrm{O} \text { Added }\end{array}$} & \multicolumn{3}{|c|}{$=$ Volume Mark on Cone $(\mathrm{mL})$} \\
\hline & & & & & \multicolumn{3}{|c|}{$=\mathrm{Wt} \mathrm{H}_{2} \mathrm{O}$ Added to Cone $(\mathrm{g})$} \\
\hline & & $\mathrm{T}\left({ }^{\circ} \mathrm{C}\right)$ & $\mathrm{D}(\mathrm{g} / \mathrm{mL})$ & Vol $\mathrm{H}_{2} \mathrm{O}$ Added & \multicolumn{3}{|c|}{$=\mathrm{Wt} \mathrm{H}_{2} \mathrm{O}(\mathrm{g}) / \mathrm{D} \mathrm{H}_{2} \mathrm{O}(\mathrm{g} / \mathrm{mL})$} \\
\hline \multirow{9}{*}{$\begin{array}{l}\text { AP-107 } \\
\text { BLDN } \\
\text { Cone } 4\end{array}$} & \multirow{3}{*}{$07 / 25 / 11$} & \multirow{3}{*}{22.5} & \multirow{3}{*}{0.99766} & Cone Mark & 10.0 & $\mathbf{1 1 . 5}$ & 13.0 \\
\hline & & & & Wt $\mathrm{H}_{2} \mathrm{O}$ Added (g) & 9.9743 & 11.3731 & 12.8469 \\
\hline & & & & $\mathrm{Vol} \mathrm{H}_{2} \mathrm{O}(\mathrm{mL})$ & 9.9977 & 11.3998 & 12.8771 \\
\hline & \multirow{3}{*}{$07 / 25 / 11$} & \multirow{3}{*}{22.5} & \multirow{3}{*}{0.99766} & Cone Mark & 10.0 & 11.5 & 13.0 \\
\hline & & & & Wt $\mathrm{H}_{2} \mathrm{O}$ Added (g) & 9.9443 & 11.3821 & 12.8540 \\
\hline & & & & $\mathrm{Vol} \mathrm{H}{ }_{2} \mathrm{O}(\mathrm{mL})$ & 9.9677 & 11.4088 & 12.8842 \\
\hline & \multirow{3}{*}{$07 / 25 / 11$} & \multirow{3}{*}{22.4} & \multirow{3}{*}{0.99768} & Cone Mark & 10.0 & 11.5 & 13.0 \\
\hline & & & & Wt $\mathrm{H}_{2} \mathrm{O}$ Added $(\mathrm{g})$ & 9.9455 & 11.3803 & 12.8814 \\
\hline & & & & $\mathrm{Vol} \mathrm{H}{ }_{2} \mathrm{O}(\mathrm{mL})$ & 9.9686 & 11.4068 & 12.9114 \\
\hline \multicolumn{4}{|c|}{ Cone 4 - Sample CON 3} & \multicolumn{4}{|c|}{$\mathrm{Vol}_{\text {Corrected }}=\left(0.9710 \times \mathrm{Vol}_{\text {Read }}\right)+0.2587$} \\
\hline
\end{tabular}

\begin{tabular}{|c|c|c|c|c|c|c|c|}
\hline \multirow{3}{*}{ Cone ID } & \multirow{3}{*}{ Cal Date } & \multirow{2}{*}{\multicolumn{2}{|c|}{$\mathrm{H}_{2} \mathrm{O}$}} & \multirow{2}{*}{$\begin{array}{r}\text { Cone Mark } \\
\text { Wt } \mathrm{H}_{2} \mathrm{O} \text { Added }\end{array}$} & \multicolumn{3}{|c|}{$=$ Volume Mark on Cone $(\mathrm{mL})$} \\
\hline & & & & & \multicolumn{3}{|c|}{$=\mathrm{Wt} \mathrm{H}_{2} \mathrm{O}$ Added to Cone $(\mathrm{g})$} \\
\hline & & $\mathrm{T}\left({ }^{\circ} \mathrm{C}\right)$ & $\mathrm{D}(\mathrm{g} / \mathrm{mL})$ & Vol $\mathrm{H}_{2} \mathrm{O}$ Added & \multicolumn{3}{|c|}{$=\mathrm{Wt} \mathrm{H}_{2} \mathrm{O}(\mathrm{g}) / \mathrm{D} \mathrm{H}_{2} \mathrm{O}(\mathrm{g} / \mathrm{mL})$} \\
\hline \multirow{9}{*}{$\begin{array}{l}\text { AP-107 } \\
\text { BLDN } \\
\text { Cone } 5\end{array}$} & \multirow{3}{*}{$07 / 25 / 11$} & \multirow{3}{*}{22.5} & \multirow{3}{*}{0.99766} & Cone Mark & 10.0 & 11.5 & 13.0 \\
\hline & & & & Wt $\mathrm{H}_{2} \mathrm{O}$ Added $(\mathrm{g})$ & 9.9526 & 11.4132 & 12.8517 \\
\hline & & & & Vol $\mathrm{H}_{2} \mathrm{O}(\mathrm{mL})$ & 9.9760 & 11.4400 & 12.8819 \\
\hline & \multirow{3}{*}{ 07/25/11 } & \multirow{3}{*}{22.5} & \multirow{3}{*}{0.99766} & Cone Mark & 10.0 & 11.5 & 13.0 \\
\hline & & & & Wt $\mathrm{H}_{2} \mathrm{O}$ Added $(\mathrm{g})$ & 9.9346 & 11.4323 & 12.8827 \\
\hline & & & & Vol $\mathrm{H}_{2} \mathrm{O}(\mathrm{mL})$ & 9.9579 & 11.4592 & 12.9130 \\
\hline & \multirow{3}{*}{ 07/25/11 } & \multirow{3}{*}{22.5} & \multirow{3}{*}{0.99766} & Cone Mark & 10.0 & 11.5 & 13.0 \\
\hline & & & & Wt $\mathrm{H}_{2} \mathrm{O}$ Added $(\mathrm{g})$ & 9.9396 & 11.4126 & 12.8840 \\
\hline & & & & $\mathrm{Vol} \mathrm{H}_{2} \mathrm{O}(\mathrm{mL})$ & 9.9629 & 11.4394 & 12.9143 \\
\hline \multicolumn{4}{|c|}{ Cone 5 - Sample CON 4} & \multicolumn{4}{|c|}{ Vol $_{\text {Corrected }}=\left(0.9792 \times \mathrm{Vol}_{\text {Read }}\right)+0.1779$} \\
\hline
\end{tabular}


LAB-RPT-12-00008, R0

Table A-1. Centrifuge Cone Volume Calibrations. (6 sheets)

\begin{tabular}{|c|c|c|c|c|c|c|c|}
\hline \multirow{3}{*}{ Cone ID } & \multirow{3}{*}{ Cal Date } & \multirow{2}{*}{\multicolumn{2}{|c|}{$\mathrm{H}_{2} \mathrm{O}$}} & \multirow{2}{*}{$\begin{array}{r}\text { Cone Mark } \\
\text { Wt } \mathrm{H}_{2} \mathrm{O} \text { Added }\end{array}$} & \multicolumn{3}{|c|}{$=$ Volume Mark on Cone $(\mathrm{mL})$} \\
\hline & & & & & \multicolumn{3}{|c|}{$=\mathrm{Wt} \mathrm{H}_{2} \mathrm{O}$ Added to Cone $(\mathrm{g})$} \\
\hline & & $\mathrm{T}\left({ }^{\circ} \mathrm{C}\right)$ & $\mathrm{D}(\mathrm{g} / \mathrm{mL})$ & Vol $\mathrm{H}_{2} \mathrm{O}$ Added & \multicolumn{3}{|c|}{$=\mathrm{Wt} \mathrm{H}_{2} \mathrm{O}(\mathrm{g}) / \mathrm{D} \mathrm{H}_{2} \mathrm{O}(\mathrm{g} / \mathrm{mL})$} \\
\hline \multirow{9}{*}{$\begin{array}{l}\text { AP-107 } \\
\text { BLDN } \\
\text { Cone } 6\end{array}$} & \multirow{3}{*}{$07 / 25 / 11$} & \multirow{3}{*}{22.3} & \multirow{3}{*}{0.99770} & Cone Mark & 10.0 & $\mathbf{1 1 . 5}$ & 13.0 \\
\hline & & & & Wt $\mathrm{H}_{2} \mathrm{O}$ Added (g) & 9.9429 & 11.3936 & 12.8602 \\
\hline & & & & $\mathrm{Vol} \mathrm{H}_{2} \mathrm{O}(\mathrm{mL})$ & 9.9658 & 11.4198 & 12.8898 \\
\hline & \multirow{3}{*}{$07 / 25 / 11$} & \multirow{3}{*}{22.3} & \multirow{3}{*}{0.99770} & Cone Mark & 10.0 & 11.5 & 13.0 \\
\hline & & & & Wt $\mathrm{H}_{2} \mathrm{O}$ Added (g) & 9.9982 & 11.4400 & 12.8992 \\
\hline & & & & $\mathrm{Vol} \mathrm{H}{ }_{2} \mathrm{O}(\mathrm{mL})$ & 10.0212 & 11.4663 & 12.9289 \\
\hline & \multirow{3}{*}{$07 / 25 / 11$} & \multirow{3}{*}{22.4} & \multirow{3}{*}{0.99768} & Cone Mark & 10.0 & 11.5 & 13.0 \\
\hline & & & & Wt $\mathrm{H}_{2} \mathrm{O}$ Added $(\mathrm{g})$ & 9.9628 & 11.4156 & 12.8535 \\
\hline & & & & $\mathrm{Vol} \mathrm{H}{ }_{2} \mathrm{O}(\mathrm{mL})$ & 9.9860 & 11.4422 & 12.8834 \\
\hline \multicolumn{4}{|c|}{ Cone 6 - Sample CON 5} & \multicolumn{4}{|c|}{$\mathrm{Vol}_{\text {Corrected }}=\left(0.9699 \times \mathrm{Vol}_{\text {Read }}\right)+0.2909$} \\
\hline
\end{tabular}

\begin{tabular}{|c|c|c|c|c|c|c|c|}
\hline \multirow{3}{*}{ Cone ID } & \multirow{3}{*}{ Cal Date } & \multirow{2}{*}{\multicolumn{2}{|c|}{$\mathrm{H}_{2} \mathrm{O}$}} & \multirow{2}{*}{$\begin{array}{r}\text { Cone Mark } \\
\text { Wt } \mathrm{H}_{2} \mathrm{O} \text { Added }\end{array}$} & \multicolumn{3}{|c|}{$=$ Volume Mark on Cone $(\mathrm{mL})$} \\
\hline & & & & & \multicolumn{3}{|c|}{$=\mathrm{Wt} \mathrm{H}_{2} \mathrm{O}$ Added to Cone $(\mathrm{g})$} \\
\hline & & $\mathrm{T}\left({ }^{\circ} \mathrm{C}\right)$ & $\mathrm{D}(\mathrm{g} / \mathrm{mL})$ & Vol $\mathrm{H}_{2} \mathrm{O}$ Added & \multicolumn{3}{|c|}{$=\mathrm{Wt} \mathrm{H}_{2} \mathrm{O}(\mathrm{g}) / \mathrm{D} \mathrm{H}_{2} \mathrm{O}(\mathrm{g} / \mathrm{mL})$} \\
\hline \multirow{9}{*}{$\begin{array}{l}\text { AP-107 } \\
\text { BLDN } \\
\text { Cone } 7\end{array}$} & \multirow{3}{*}{$07 / 25 / 11$} & \multirow{3}{*}{22.6} & \multirow{3}{*}{0.99763} & Cone Mark & 10.0 & 11.5 & 13.0 \\
\hline & & & & Wt $\mathrm{H}_{2} \mathrm{O}$ Added $(\mathrm{g})$ & 9.9323 & 11.3952 & 12.8581 \\
\hline & & & & Vol $\mathrm{H}_{2} \mathrm{O}(\mathrm{mL})$ & 9.9559 & 11.4222 & 12.8886 \\
\hline & \multirow{3}{*}{ 07/25/11 } & \multirow{3}{*}{22.6} & \multirow{3}{*}{0.99763} & Cone Mark & 10.0 & 11.5 & 13.0 \\
\hline & & & & Wt $\mathrm{H}_{2} \mathrm{O}$ Added $(\mathrm{g})$ & 9.9572 & 11.3749 & 12.8559 \\
\hline & & & & $\mathrm{Vol} \mathrm{H}_{2} \mathrm{O}(\mathrm{mL})$ & 9.9808 & 11.4019 & 12.8864 \\
\hline & \multirow{3}{*}{ 07/25/11 } & \multirow{3}{*}{22.6} & \multirow{3}{*}{0.99763} & Cone Mark & 10.0 & 11.5 & 13.0 \\
\hline & & & & Wt $\mathrm{H}_{2} \mathrm{O}$ Added $(\mathrm{g})$ & 9.9149 & 11.4045 & 12.8549 \\
\hline & & & & $\mathrm{Vol} \mathrm{H}_{2} \mathrm{O}(\mathrm{mL})$ & 9.9384 & 11.4316 & 12.8854 \\
\hline \multicolumn{4}{|c|}{ Cone 7 - Sample CON 6} & \multicolumn{4}{|c|}{ Vol $_{\text {Corrected }}=\left(0.9761 \times \mathrm{Vol}_{\text {Read }}\right)+0.1963$} \\
\hline
\end{tabular}


LAB-RPT-12-00008, R0

Table A-1. Centrifuge Cone Volume Calibrations. (6 sheets)

\begin{tabular}{|c|c|c|c|c|c|c|c|}
\hline \multirow{3}{*}{ Cone ID } & \multirow{3}{*}{ Cal Date } & \multirow{2}{*}{\multicolumn{2}{|c|}{$\mathrm{H}_{2} \mathrm{O}$}} & \multirow{3}{*}{$\begin{array}{r}\text { Cone Mark } \\
\text { Wt } \mathrm{H}_{2} \mathrm{O} \text { Added } \\
\text { Vol } \mathrm{H}_{2} \mathrm{O} \text { Added }\end{array}$} & \\
\hline & & & & & \multicolumn{3}{|c|}{$=\mathrm{Wt}_{2} \mathrm{O}$ Added to Cone $(\mathrm{g})$} \\
\hline & & $\mathrm{T}\left({ }^{\circ} \mathrm{C}\right)$ & $\mathrm{D}(\mathrm{g} / \mathrm{mL})$ & & \multicolumn{3}{|c|}{$=\mathrm{Wt} \mathrm{H}_{2} \mathrm{O}(\mathrm{g}) / \mathrm{D} \mathrm{H}_{2} \mathrm{O}(\mathrm{g} / \mathrm{mL})$} \\
\hline \multirow{18}{*}{$\begin{array}{l}\text { AP-107 } \\
\text { BLDN } \\
\text { Cone } 8\end{array}$} & \multirow{3}{*}{$07 / 25 / 11$} & \multirow{3}{*}{22.5} & \multirow{3}{*}{0.99766} & Cone Mark & 10.0 & 11.5 & 13.0 \\
\hline & & & & Wt $\mathrm{H}_{2} \mathrm{O}$ Added (g) & 10.0309 & 11.4779 & 12.9459 \\
\hline & & & & $\mathrm{Vol} \mathrm{H}_{2} \mathrm{O}(\mathrm{mL})$ & 10.0545 & 11.5049 & 12.9763 \\
\hline & \multirow{3}{*}{$07 / 25 / 11$} & \multirow{3}{*}{22.5} & \multirow{3}{*}{0.99766} & Cone Mark & 10.0 & 11.5 & 13.0 \\
\hline & & & & Wt $\mathrm{H}_{2} \mathrm{O}$ Added (g) & 10.0791 & 11.4883 & 12.9631 \\
\hline & & & & $\mathrm{Vol} \mathrm{H}_{2} \mathrm{O}(\mathrm{mL})$ & 10.1028 & 11.5153 & 12.9936 \\
\hline & \multirow{3}{*}{$07 / 25 / 11$} & \multirow{3}{*}{22.6} & \multirow{3}{*}{0.99763} & Cone Mark & 10.0 & 11.5 & 13.0 \\
\hline & & & & Wt $\mathrm{H}_{2} \mathrm{O}$ Added (g) & 10.0323 & 11.5509 & 12.9661 \\
\hline & & & & $\mathrm{Vol} \mathrm{H}_{2} \mathrm{O}(\mathrm{mL})$ & 10.0561 & 11.5783 & 12.9969 \\
\hline & \multirow{3}{*}{$07 / 27 / 11$} & \multirow{3}{*}{22.9} & \multirow{3}{*}{0.99756} & Cone Mark & 10.0 & 11.5 & 13.0 \\
\hline & & & & Wt $\mathrm{H}_{2} \mathrm{O}$ Added $(\mathrm{g})$ & 10.0317 & 11.5397 & 12.9927 \\
\hline & & & & $\mathrm{Vol} \mathrm{H}_{2} \mathrm{O}(\mathrm{mL})$ & 10.0562 & 11.5679 & 13.0245 \\
\hline & \multirow{3}{*}{$07 / 27 / 11$} & \multirow{3}{*}{22.9} & \multirow{3}{*}{0.99756} & Cone Mark & 10.0 & 11.5 & 13.0 \\
\hline & & & & Wt $\mathrm{H}_{2} \mathrm{O}$ Added $(\mathrm{g})$ & 10.0576 & 11.5299 & 12.9661 \\
\hline & & & & $\mathrm{Vol} \mathrm{H}_{2} \mathrm{O}(\mathrm{mL})$ & 10.0822 & 11.5581 & 12.9978 \\
\hline & \multirow{3}{*}{$07 / 27 / 11$} & \multirow{3}{*}{22.9} & \multirow{3}{*}{0.99756} & Cone Mark & 10.0 & 11.5 & 13.0 \\
\hline & & & & Wt $\mathrm{H}_{2} \mathrm{O}$ Added (g) & 10.0616 & 11.4803 & 13.0049 \\
\hline & & & & $\mathrm{Vol} \mathrm{H}_{2} \mathrm{O}(\mathrm{mL})$ & 10.0862 & 11.5084 & 13.0367 \\
\hline \multicolumn{4}{|c|}{ Cone 8 - Sample CON 7} & \multicolumn{4}{|c|}{$\mathrm{Vol}_{\text {Corrected }}=\left(0.9771 \times \mathrm{Vol}_{\text {Read }}\right)+0.3019$} \\
\hline
\end{tabular}

\begin{tabular}{|c|c|c|c|c|c|c|c|}
\hline \multirow{3}{*}{ Cone ID } & \multirow{3}{*}{ Cal Date } & \multirow{2}{*}{\multicolumn{2}{|c|}{$\mathrm{H}_{2} \mathrm{O}$}} & \multicolumn{4}{|c|}{$=$ Volume Mark on Cone $(\mathrm{mL})$} \\
\hline & & & & \multirow{2}{*}{$\begin{array}{c}\text { Wt } \mathrm{H}_{2} \mathrm{O} \text { Added } \\
\text { Vol } \mathrm{H}_{2} \mathrm{O} \text { Added }\end{array}$} & \multicolumn{3}{|c|}{$=\mathrm{Wt} \mathrm{H}_{2} \mathrm{O}$ Added to Cone $(\mathrm{g})$} \\
\hline & & $\mathrm{T}\left({ }^{\circ} \mathrm{C}\right)$ & $\mathrm{D}(\mathrm{g} / \mathrm{mL})$ & & \multicolumn{3}{|c|}{$=\mathrm{Wt} \mathrm{H}_{2} \mathrm{O}(\mathrm{g}) / \mathrm{D} \mathrm{H}_{2} \mathrm{O}(\mathrm{g} / \mathrm{mL})$} \\
\hline \multirow{9}{*}{$\begin{array}{l}\text { AP-107 } \\
\text { BLDN } \\
\text { Cone } 9\end{array}$} & \multirow{3}{*}{$07 / 25 / 11$} & \multirow{3}{*}{22.5} & \multirow{3}{*}{0.99766} & Cone Mark & 10.0 & $\mathbf{1 1 . 5}$ & 13.0 \\
\hline & & & & Wt $\mathrm{H}_{2} \mathrm{O}$ Added $(\mathrm{g})$ & 9.9209 & 11.3912 & 12.8626 \\
\hline & & & & $\mathrm{Vol} \mathrm{H} \mathrm{H}_{2} \mathrm{O}(\mathrm{mL})$ & 9.9442 & 11.4180 & 12.8928 \\
\hline & \multirow{3}{*}{$07 / 25 / 11$} & \multirow{3}{*}{22.4} & \multirow{3}{*}{0.99768} & Cone Mark & 10.0 & 11.5 & 13.0 \\
\hline & & & & Wt $\mathrm{H}_{2} \mathrm{O}$ Added (g) & 9.9363 & 11.3755 & 12.8726 \\
\hline & & & & $\mathrm{Vol} \mathrm{H} \mathrm{H}_{2} \mathrm{O}(\mathrm{mL})$ & 9.9594 & 11.4020 & 12.9025 \\
\hline & \multirow{3}{*}{$07 / 25 / 11$} & \multirow{3}{*}{22.5} & \multirow{3}{*}{0.99766} & Cone Mark & 10.0 & $\mathbf{1 1 . 5}$ & 13.0 \\
\hline & & & & Wt $\mathrm{H}_{2} \mathrm{O}$ Added $(\mathrm{g})$ & 9.9521 & 11.4144 & 12.8538 \\
\hline & & & & $\mathrm{Vol} \mathrm{H}_{2} \mathrm{O}(\mathrm{mL})$ & 9.9754 & 11.4412 & 12.8840 \\
\hline \multicolumn{4}{|c|}{ Cone 9 - Sample DIL 1} & \multicolumn{4}{|c|}{$\mathrm{Vol}_{\text {Corrected }}=\left(0.9778 \times \mathrm{Vol}_{\text {Read }}\right)+0.1796$} \\
\hline
\end{tabular}


LAB-RPT-12-00008, R0

Table A-1. Centrifuge Cone Volume Calibrations. (6 sheets)

\begin{tabular}{|c|c|c|c|c|c|c|c|}
\hline \multirow{3}{*}{ Cone ID } & \multirow{3}{*}{ Cal Date } & \multirow{2}{*}{\multicolumn{2}{|c|}{$\mathrm{H}_{2} \mathrm{O}$}} & \multirow{2}{*}{$\begin{array}{r}\text { Cone Mark } \\
\mathrm{Wt} \mathrm{H}_{2} \mathrm{O} \text { Added }\end{array}$} & \multicolumn{3}{|c|}{$=$ Volume Mark on Cone $(\mathrm{mL})$} \\
\hline & & & & & \multicolumn{3}{|c|}{$=\mathrm{Wt} \mathrm{H}_{2} \mathrm{O}$ Added to Cone $(\mathrm{g})$} \\
\hline & & $\mathrm{T}\left({ }^{\circ} \mathrm{C}\right)$ & $\mathrm{D}(\mathrm{g} / \mathrm{mL})$ & Vol $\mathrm{H}_{2} \mathrm{O}$ Added & \multicolumn{3}{|c|}{$=\mathrm{Wt} \mathrm{H}_{2} \mathrm{O}(\mathrm{g}) / \mathrm{D} \mathrm{H}_{2} \mathrm{O}(\mathrm{g} / \mathrm{mL})$} \\
\hline \multirow{9}{*}{$\begin{array}{c}\text { AP-107 } \\
\text { BLDN } \\
\text { Cone } 10\end{array}$} & \multirow{3}{*}{$07 / 25 / 11$} & \multirow{3}{*}{22.3} & \multirow{3}{*}{0.99770} & Cone Mark & 10.0 & 11.5 & 13.0 \\
\hline & & & & Wt $\mathrm{H}_{2} \mathrm{O}$ Added (g) & 9.9715 & 11.4610 & 12.9076 \\
\hline & & & & $\mathrm{Vol} \mathrm{H}{ }_{2} \mathrm{O}(\mathrm{mL})$ & 9.9945 & 11.4874 & 12.9373 \\
\hline & \multirow{3}{*}{$07 / 25 / 11$} & \multirow{3}{*}{22.4} & \multirow{3}{*}{0.99768} & Cone Mark & 10.0 & 11.5 & 13.0 \\
\hline & & & & Wt $\mathrm{H}_{2} \mathrm{O}$ Added (g) & 10.0295 & 11.4442 & 12.9045 \\
\hline & & & & $\mathrm{Vol} \mathrm{H}{ }_{2} \mathrm{O}(\mathrm{mL})$ & 10.0528 & 11.4708 & 12.9345 \\
\hline & \multirow{3}{*}{$07 / 25 / 11$} & \multirow{3}{*}{22.5} & \multirow{3}{*}{0.99766} & Cone Mark & 10.0 & 11.5 & 13.0 \\
\hline & & & & Wt $\mathrm{H}_{2} \mathrm{O}$ Added (g) & 10.0144 & 11.4744 & 12.9323 \\
\hline & & & & $\mathrm{Vol} \mathrm{H} \mathrm{H}_{2} \mathrm{O}(\mathrm{mL})$ & 10.0379 & 11.5014 & 12.9627 \\
\hline \multicolumn{4}{|c|}{ Cone 10 - Sample DIL 2} & \multicolumn{4}{|c|}{$\mathrm{Vol}_{\text {Corrected }}=\left(0.9721 \times \mathrm{Vol}_{\text {Read }}\right)+0.3069$} \\
\hline
\end{tabular}

\begin{tabular}{|c|c|c|c|c|c|c|c|}
\hline \multirow{3}{*}{ Cone ID } & \multirow{3}{*}{ Cal Date } & \multirow{2}{*}{\multicolumn{2}{|c|}{$\mathrm{H}_{2} \mathrm{O}$}} & \multirow{2}{*}{$\begin{array}{r}\text { Cone Mark } \\
\mathrm{Wt} \mathrm{H}_{2} \mathrm{O} \text { Added } \\
\end{array}$} & \multicolumn{3}{|c|}{$=$ Volume Mark on Cone $(\mathrm{mL})$} \\
\hline & & & & & \multicolumn{3}{|c|}{$=\mathrm{Wt}_{2} \mathrm{O}$ Added to Cone $(\mathrm{g})$} \\
\hline & & $\mathrm{T}\left({ }^{\circ} \mathrm{C}\right)$ & $\mathrm{D}(\mathrm{g} / \mathrm{mL})$ & $\mathrm{Vol} \mathrm{H}_{2} \mathrm{O}$ Added & \multicolumn{3}{|c|}{$=\mathrm{Wt} \mathrm{H}_{2} \mathrm{O}(\mathrm{g}) / \mathrm{D} \mathrm{H}_{2} \mathrm{O}(\mathrm{g} / \mathrm{mL})$} \\
\hline \multirow{9}{*}{$\begin{array}{l}\text { AP-107 } \\
\text { BLDN } \\
\text { Cone } 11\end{array}$} & \multirow{3}{*}{$07 / 25 / 11$} & \multirow{3}{*}{22.6} & \multirow{3}{*}{0.99763} & Cone Mark & 10.0 & 11.5 & 13.0 \\
\hline & & & & Wt $\mathrm{H}_{2} \mathrm{O}$ Added (g) & 9.9381 & 11.3823 & 12.8376 \\
\hline & & & & $\mathrm{Vol} \mathrm{H}_{2} \mathrm{O}(\mathrm{mL})$ & 9.9617 & 11.4093 & 12.8681 \\
\hline & \multirow{3}{*}{$07 / 25 / 11$} & \multirow{3}{*}{22.6} & \multirow{3}{*}{0.99763} & Cone Mark & 10.0 & 11.5 & 13.0 \\
\hline & & & & Wt $\mathrm{H}_{2} \mathrm{O}$ Added (g) & 9.9010 & 11.3961 & 12.8335 \\
\hline & & & & $\mathrm{Vol} \mathrm{H}_{2} \mathrm{O}(\mathrm{mL})$ & 9.9245 & 11.4232 & 12.8640 \\
\hline & \multirow{3}{*}{$07 / 25 / 11$} & \multirow{3}{*}{22.6} & \multirow{3}{*}{0.99763} & Cone Mark & 10.0 & 11.5 & 13.0 \\
\hline & & & & Wt $\mathrm{H}_{2} \mathrm{O}$ Added $(\mathrm{g})$ & 9.9402 & 11.4269 & 12.8353 \\
\hline & & & & $\mathrm{Vol} \mathrm{H}_{2} \mathrm{O}(\mathrm{mL})$ & 9.9638 & 11.4540 & 12.8658 \\
\hline \multicolumn{4}{|c|}{ Cone 11 - Sample DIL 3} & \multicolumn{4}{|c|}{$\mathrm{Vol}_{\text {Corrected }}=\left(0.9719 \times \mathrm{Vol}_{\text {Read }}\right)+0.2379$} \\
\hline
\end{tabular}


LAB-RPT-12-00008, R0

ATTACHMENT B

BOILDOWN HOT CELL DATA LOGS

B-1 


\section{ATTACHMENT B BOILDOWN HOT CELL DATA LOGS}

The hot cell data log reproduced in Table B-1 was used to track the progress of the boildown operations and to calculate volumes of water $\left(\Delta \mathrm{H}_{2} \mathrm{O}\right)$ that needed to be distilled from or added to the test sample to reach target concentrations or densities. Quantities of water removed from or added to the boildown pot were weighed and then converted to volumes by dividing by the density of pure water at $26.8{ }^{\circ} \mathrm{C}$. The volumes of samples removed from the pot were calculated by dividing the weight of the samples by the model density $\left(\mathrm{D}_{\text {Model }}{ }^{26.8^{\circ} \mathrm{C}}\right)$ calculated by the $\log$ spreadsheet.

A registered and verified Excel spreadsheet (RPP-38843, Spreadsheet Description Document for Boildown Test Data Spreadsheet; SVF-1543 Rev. 0, "CH2M HILL Spreadsheet Verification and Release Form") was used to generate the hot cell data log. Within the log, the chronology of entries proceeds from left to right across a row, and then down to the following row.

The primary hot cell data log was subsequently modified by changing the base reference temperature for the model calculations from $26.8^{\circ} \mathrm{C}$ to $18{ }^{\circ} \mathrm{C}$. This revised data log is presented in Table B-2.

The column headings/entries in the data logs are defined as follows:

\begin{tabular}{|c|c|}
\hline \multirow[t]{2}{*}{ Sample Rmvd (mL) } & Volume of sample withdrawn from pot at beginning of Step \\
\hline & $=$ Manual data entry \\
\hline \multirow[t]{2}{*}{ Pot Vol Initial (mL) } & $\begin{array}{l}\text { Volume of pot contents after removal of a sample following the } \\
\text { conclusion of a preceding concentration/dilution step }\end{array}$ \\
\hline & $=(\text { Pot Vol Final })_{\text {previous }}-(\text { Sample Vol Corrected })_{\text {current }}$ \\
\hline \multirow[t]{2}{*}{$\Delta \mathrm{H}_{2} \mathrm{O}(\mathrm{mL})$} & $\begin{array}{l}\text { Volume of water removed from or added to pot contents during a } \\
\text { concentration/dilution step }\end{array}$ \\
\hline & $=$ Manual data entry with additions entered as negative values \\
\hline \multirow[t]{2}{*}{ Pot Vol Final (mL) } & Final volume of pot contents for a step \\
\hline & $=(\text { Pot Vol Initial })_{\text {current }}-\left(\Delta \mathrm{H}_{2} \mathrm{O}\right)_{\text {current }}$ \\
\hline \multirow[t]{2}{*}{$C R$ Step } & (Incremental) concentration ratio for a step \\
\hline & $=(\text { Pot Vol Initial })_{\text {current }} \div(\text { Pot Vol Final })_{\text {current }}$ \\
\hline \multirow[t]{2}{*}{$C R$ Total } & $\begin{array}{l}\text { (Cumulative) concentration ratio applicable to a boildown since } \\
\text { the last baseline reset }\end{array}$ \\
\hline & $=(C R \text { Total })_{\text {previous }} \times(C R \text { Step })_{\text {current }}$ \\
\hline
\end{tabular}




\begin{tabular}{|c|c|}
\hline \multirow[t]{2}{*}{$\% \mathrm{WVR}$} & $\begin{array}{l}\% \text { waste volume reduction applicable to a boildown since the last } \\
\text { baseline reset }\end{array}$ \\
\hline & $=\left\{\left[(\mathrm{CR} \text { Total })_{\text {current }}-1.0\right] \div(C R \text { Total })_{\text {current }}\right\} \times 100$ \\
\hline \multirow[t]{2}{*}{$\mathrm{D}_{\text {Model }}(\mathrm{g} / \mathrm{mL})$} & $\begin{array}{l}\text { Calculated density of pot contents, based on simple additive } \\
\text { additions model, at the end of a boildown step }\end{array}$ \\
\hline & $=\left[\left(\mathrm{D}_{\text {Initial Composite }}-\mathrm{D}_{\mathrm{H} 2 \mathrm{O}}\right) \times C R\right.$ Total $]+\mathrm{D}_{\mathrm{H} 2 \mathrm{O}}$ \\
\hline \multirow[t]{2}{*}{$P_{\text {Read }}$ (Torr) } & $\begin{array}{l}\text { Pressure in the boildown apparatus read from pressure } \\
\text { reader/controller }\end{array}$ \\
\hline & $=$ Manual data entry \\
\hline \multirow[t]{2}{*}{$\mathrm{P}_{\text {Corr }}$ (Torr) } & Corrected pressure in boildown apparatus \\
\hline & $=0.9823\left(\mathrm{P}_{\text {Read }}\right)+1.720$ \\
\hline \multirow[t]{2}{*}{$\mathrm{T}_{\text {Read }}\left({ }^{\circ} \mathrm{C}\right)$} & $\begin{array}{l}\text { Temperature of pot contents from readout of K-type } \\
\text { thermocouple/reader }\end{array}$ \\
\hline & $=$ Manual data entry \\
\hline \multirow[t]{2}{*}{$\mathrm{T}_{\text {Corr }}\left({ }^{\circ} \mathrm{C}\right)$} & Corrected temperature of pot contents \\
\hline & $=1.69 \times 10^{-6}\left(\mathrm{~T}_{\text {Read }}\right)^{3}-5.59 \times 10^{-4}\left(\mathrm{~T}_{\text {Read }}\right)^{2}+1.03\left(\mathrm{~T}_{\text {Read }}\right)-0.197$ \\
\hline
\end{tabular}

The abbreviations used in the row entries in the 'Action' column are defined as follows:

\begin{tabular}{|l|l|}
\hline CON \# & Boildown volume reduction Step \# and Sample \# \\
\hline DIL \# & Boildown dilution Step \# and Sample \# \\
\hline P/T Step \# [ $\left.\mathrm{P}_{\text {nominal }}\right]$ & $\begin{array}{l}\text { Measurement of boiling temperature (T) and system pressure (P) } \\
\text { during specified boildown/ dilution step (\#) at nominal test } \\
\text { pressure of 40, 60, or 80 Torr }\end{array}$ \\
\hline
\end{tabular}


Table B-1. Tank 241-AP-107 Boildown Hot Cell Data Log. (3 sheets)

Vol Initial Composite $(\mathrm{mL})=578.170 \mathrm{~g} / 1.21599 \mathrm{~g} / \mathrm{mL}$

$\Delta \mathrm{H}_{2} \mathrm{O}(\mathrm{mL})=\mathrm{Wt} \mathrm{H}_{2} \mathrm{O} / \mathrm{D}_{\mathrm{H} 2 \mathrm{O}}$ at $26.8{ }^{\circ} \mathrm{C}$

Sample Rmvd $(\mathrm{mL})=\mathrm{Wt}$ Sample $/ \mathrm{D}_{\text {Model }}{ }^{26.8^{\circ} \mathrm{C}}$

\begin{tabular}{|c|c|c|c|c|c|c|c|c|c|c|c|c|c|c|}
\hline & & & & & & & & & . $\mathrm{D}_{\mathrm{H} 2 \mathrm{O}}$ & 0.996568 & & & & \\
\hline 20 & 11 & Action & Sample & Pot Vol & $4 \mathrm{H}_{2} \mathrm{O}$ & Pot Vol & CR & CR & $\% W V R$ & $\mathbf{D}_{\text {Model }}$ & $\mathbf{P}_{\text {Read }}$ & $\mathbf{P}_{\text {Corr }}$ & $T_{\text {Read }}$ & $T_{\text {Corr }}$ \\
\hline $\begin{array}{c}\text { Date } \\
\mathrm{mm} / \mathrm{dd}\end{array}$ & $\begin{array}{c}\begin{array}{c}\text { Time } \\
\text { hh:mm }\end{array} \\
\end{array}$ & & $\begin{array}{c}\text { Rmvd } \\
(\mathrm{mL})\end{array}$ & $\begin{array}{c}\text { Initial } \\
(\mathrm{mL})\end{array}$ & (mL) & $\begin{array}{l}\text { Final } \\
(\mathrm{mL})\end{array}$ & & Total & & $(\mathrm{g} / \mathrm{mL})$ & (Torr) & (Torr) & $\left({ }^{\circ} \mathbf{C}\right)$ & $\left({ }^{\circ} \mathrm{C}\right)$ \\
\hline $10 / 03$ & $08: 30$ & Initial Composite & 0.0 & 475.473 & 0.0 & 475.473 & 1.0000 & 1.0000 & 0.000 & 1.2160 & & & & \\
\hline & 09:25 & $\mathrm{P} / \mathrm{T} 0$ [40] & 0.0 & 475.473 & 0.0 & 475.473 & 1.0000 & 1.0000 & 0.000 & 1.2160 & 40 & 41 & 37.6 & 37.9 \\
\hline & 09:38 & $\mathrm{P} / \mathrm{T} 0$ [60] & 0.0 & 475.473 & 0.0 & 475.473 & 1.0000 & 1.0000 & 0.000 & 1.2160 & 60 & 61 & 44.6 & 44.9 \\
\hline & 09:53 & $\mathrm{P} / \mathrm{T} 0$ [80] & 0.0 & 475.473 & 0.0 & 475.473 & 1.0000 & 1.0000 & 0.000 & 1.2160 & 79 & 79 & 50.4 & 50.6 \\
\hline & $10: 00$ & CON 1a [40] & 0.0 & 475.473 & 45.342 & 430.131 & 1.1054 & 1.1054 & 9.536 & 1.2391 & & & & \\
\hline & $10: 54$ & $\mathrm{P} / \mathrm{T}$ 1a [40] & 0.0 & 430.131 & 0.0 & 430.131 & 1.0000 & 1.1054 & 9.536 & 1.2391 & 39 & 40 & 37.3 & 37.6 \\
\hline & $11: 06$ & $\mathrm{P} / \mathrm{T}$ 1a [60] & 0.0 & 430.131 & 0.0 & 430.131 & 1.0000 & 1.1054 & 9.536 & 1.2391 & 60 & 61 & 45.3 & 45.6 \\
\hline & $11: 13$ & $\mathrm{P} / \mathrm{T} 1 \mathrm{a}[80]$ & 0.0 & 430.131 & 0.0 & 430.131 & 1.0000 & 1.1054 & 9.536 & 1.2391 & 79 & 79 & 50.7 & 50.9 \\
\hline & $11: 17$ & CON 1b [40] & 0.0 & 430.131 & 46.228 & 383.903 & 1.1204 & 1.2385 & 19.259 & 1.2683 & & & & \\
\hline & $12: 01$ & $\mathrm{P} / \mathrm{T} 1 \mathrm{~b}[40]$ & 0.0 & 383.903 & 0.0 & 383.903 & 1.0000 & 1.2385 & 19.259 & 1.2683 & 39 & 40 & 38.0 & 38.3 \\
\hline & $12: 11$ & $\mathrm{P} / \mathrm{T} 1 \mathrm{~b}[60]$ & 0.0 & 383.903 & 0.0 & 383.903 & 1.0000 & 1.2385 & 19.259 & 1.2683 & 58 & 59 & 45.2 & 45.5 \\
\hline & $12: 18$ & $\mathrm{P} / \mathrm{T} 1 \mathrm{~b}[80]$ & 0.0 & 383.903 & 0.0 & 383.903 & 1.0000 & 1.2385 & 19.259 & 1.2683 & 79 & 79 & 51.3 & 51.5 \\
\hline & $12: 22$ & CON 1c [40] & 0.0 & 383.903 & 44.013 & 339.890 & 1.1295 & 1.3989 & 28.515 & 1.3035 & & & & \\
\hline & 13:03 & $\mathrm{P} / \mathrm{T} 1 \mathrm{c}[40]$ & 0.0 & 339.890 & 0.0 & 339.890 & 1.0000 & 1.3989 & 28.515 & 1.3035 & 39 & 40 & 38.5 & 38.8 \\
\hline & $13: 15$ & $\mathrm{P} / \mathrm{T}$ 1c [60] & 0.0 & 339.890 & 0.0 & 339.890 & 1.0000 & 1.3989 & 28.515 & 1.3035 & 59 & 60 & 46.0 & 46.3 \\
\hline & 13:21 & $\mathrm{P} / \mathrm{T} 1 \mathrm{c}[80]$ & 0.0 & 339.890 & 0.0 & 339.890 & 1.0000 & 1.3989 & 28.515 & 1.3035 & 79 & 79 & 51.8 & 52.0 \\
\hline & $13: 50$ & SAMPLE CON 1 & 12.136 & 327.753 & 0.0 & 327.753 & 1.0000 & 1.3989 & 28.515 & 1.3035 & & & & \\
\hline
\end{tabular}


Table B-1. Tank 241-AP-107 Boildown Hot Cell Data Log. (3 sheets)

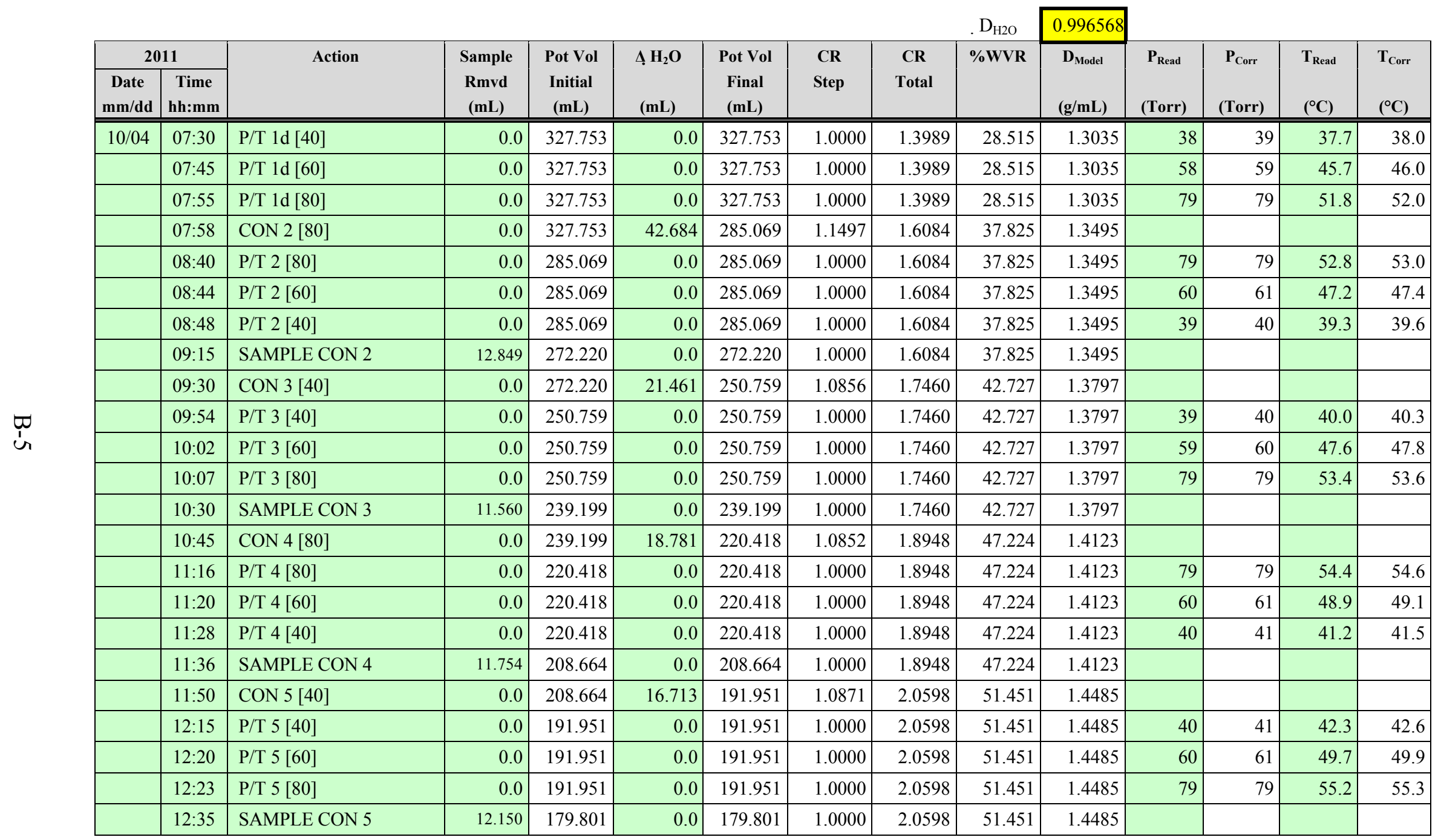


Table B-1. Tank 241-AP-107 Boildown Hot Cell Data Log. (3 sheets)

\begin{tabular}{|c|c|c|c|c|c|c|c|c|c|c|c|c|c|c|}
\hline & & & & & & & & & . $\mathrm{D}_{\mathrm{H} 2 \mathrm{O}}$ & 0.996568 & & & & \\
\hline 20 & 11 & Action & Sample & Pot Vol & $4 \mathrm{H}_{2} \mathrm{O}$ & Pot Vol & $\mathbf{C R}$ & CR & $\% W V R$ & $\mathbf{D}_{\text {Model }}$ & $P_{\text {Read }}$ & $\mathbf{P}_{\text {Corr }}$ & $T_{\text {Read }}$ & $T_{\text {Corr }}$ \\
\hline $\begin{array}{c}\text { Date } \\
\mathrm{mm} / \mathrm{ddd}\end{array}$ & $\begin{array}{c}\text { Time } \\
\text { hh:mm } \\
\end{array}$ & & $\begin{array}{c}\text { Rmvd } \\
(\mathrm{mL})\end{array}$ & $\begin{array}{c}\text { Initial } \\
(\mathrm{mL}) \\
\end{array}$ & (mL) & $\begin{array}{l}\text { Final } \\
(\mathrm{mL}) \\
\end{array}$ & Step & Total & & $(\mathrm{g} / \mathrm{mL})$ & (Torr) & (Torr) & $\left({ }^{\circ} \mathrm{C}\right)$ & $\left({ }^{\circ} \mathrm{C}\right)$ \\
\hline $10 / 04$ & 13:00 & CON 6 [80] & 0.0 & 179.801 & 15.114 & 164.687 & 1.0918 & 2.2488 & 55.532 & 1.4900 & & & & \\
\hline & $13: 36$ & P/T 6 [80] & 0.0 & 164.687 & 0.0 & 164.687 & 1.0000 & 2.2488 & 55.532 & 1.4900 & 79 & 79 & 56.7 & 56.8 \\
\hline & $13: 40$ & $\mathrm{P} / \mathrm{T} 6[60]$ & 0.0 & 164.687 & 0.0 & 164.687 & 1.0000 & 2.2488 & 55.532 & 1.4900 & 59 & 60 & 50.6 & 50.8 \\
\hline & $13: 44$ & $\mathrm{P} / \mathrm{T} 6[40]$ & 0.0 & 164.687 & 0.0 & 164.687 & 1.0000 & 2.2488 & 55.532 & 1.4900 & 39 & 40 & 42.7 & 43.0 \\
\hline & $14: 02$ & SAMPLE CON 6 & 11.919 & 152.768 & 0.0 & 152.768 & 1.0000 & 2.2488 & 55.532 & 1.4900 & & & & \\
\hline & $14: 18$ & CON 7 [40] & 0.0 & 152.768 & 11.646 & 141.122 & 1.0825 & 2.4344 & 58.922 & 1.5307 & & & & \\
\hline & $14: 37$ & $\mathrm{P} / \mathrm{T} 7$ [40] & 0.0 & 141.122 & 0.0 & 141.122 & 1.0000 & 2.4344 & 58.922 & 1.5307 & 39 & 40 & 43.1 & 43.4 \\
\hline & $14: 41$ & $\mathrm{P} / \mathrm{T} 7$ [60] & 0.0 & 141.122 & 0.0 & 141.122 & 1.0000 & 2.4344 & 58.922 & 1.5307 & 60 & 61 & 51.3 & $\overline{51.5}$ \\
\hline & $14: 47$ & $\mathrm{P} / \mathrm{T} 7$ [80] & 0.0 & 141.122 & 0.0 & 141.122 & 1.0000 & 2.4344 & 58.922 & 1.5307 & 80 & 80 & 57.0 & 57.1 \\
\hline & $15: 04$ & SAMPLE CON 7 & 12.980 & 128.142 & 0.0 & 128.142 & 1.0000 & 2.4344 & 58.922 & 1.5307 & & & & \\
\hline & $15: 34$ & DIL 1 & 0.0 & 128.142 & -120.453 & 248.595 & 0.5155 & 1.2548 & 20.308 & 1.2719 & & & & \\
\hline & $16: 00$ & $\mathrm{P} / \mathrm{T} 8$ [60] & 0.0 & 248.595 & 0.0 & 248.595 & 1.0000 & 1.2548 & 20.308 & 1.2719 & 59 & 60 & 45.6 & 45.9 \\
\hline & $16: 12$ & SAMPLE DIL 1 & 12.834 & 235.762 & 0.0 & 235.762 & 1.0000 & 1.2548 & 20.308 & 1.2719 & & & & \\
\hline & $16: 40$ & DIL 2 & 0.0 & 235.762 & -16.256 & 252.018 & 0.9355 & 1.1739 & 14.814 & 1.2541 & & & & \\
\hline & $16: 59$ & $\mathrm{P} / \mathrm{T} 9$ [60] & 0.0 & 252.018 & 0.0 & 252.018 & 1.0000 & 1.1739 & 14.814 & 1.2541 & 59 & 60 & 45.4 & 45.7 \\
\hline & 17:07 & SAMPLE DIL 2 & 13.084 & 238.934 & 0.0 & 238.934 & 1.0000 & 1.1739 & 14.814 & 1.2541 & & & & \\
\hline & $17: 37$ & DIL 3 & 0.0 & 238.934 & -18.192 & 257.126 & 0.9292 & 1.0908 & 8.328 & 1.2359 & & & & \\
\hline & $17: 54$ & $\mathrm{P} / \mathrm{T} 10[60]$ & 0.0 & 257.126 & 0.0 & 257.126 & 1.0000 & 1.0908 & 8.328 & 1.2359 & 59 & 60 & 45.0 & 45.3 \\
\hline & 18:05 & SAMPLE DIL 3 & 12.836 & 244.290 & 0.0 & 244.290 & 1.0000 & 1.0908 & 8.328 & 1.2359 & & & & \\
\hline
\end{tabular}


Table B-2. Revised Tank 241-AP-107 Boildown Hot Cell Data Log. (3 sheets)

Initial Composite $\mathrm{Vol}^{18^{\circ} \mathrm{C}}(\mathrm{mL})=\mathrm{Vol}^{26.8^{\circ} \mathrm{C}}+\left[\left(\mathrm{Vol}^{26.8^{\circ} \mathrm{C}}\right)(0.00043349 \Delta \mathrm{V} / \mathrm{mL})\left(-8.8 \Delta^{\circ} \mathrm{C}\right)\right]$

Initial Composite $\mathrm{D}_{\text {Model }}{ }^{\circ{ }^{\circ} \mathrm{C}}(\mathrm{g} / \mathrm{mL})=578.170 \mathrm{~g} / \mathrm{Vol}^{18{ }^{\circ} \mathrm{C}}$

$$
\Delta \mathrm{H}_{2} \mathrm{O}(\mathrm{mL})=\mathrm{Wt} \mathrm{H}_{2} \mathrm{O} / \mathrm{D}_{\mathrm{H} 2 \mathrm{O}}{ }^{1{ }^{\circ} \mathrm{C}}
$$

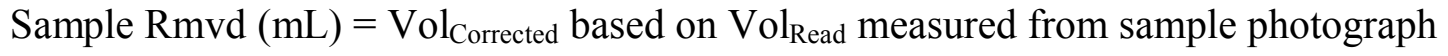

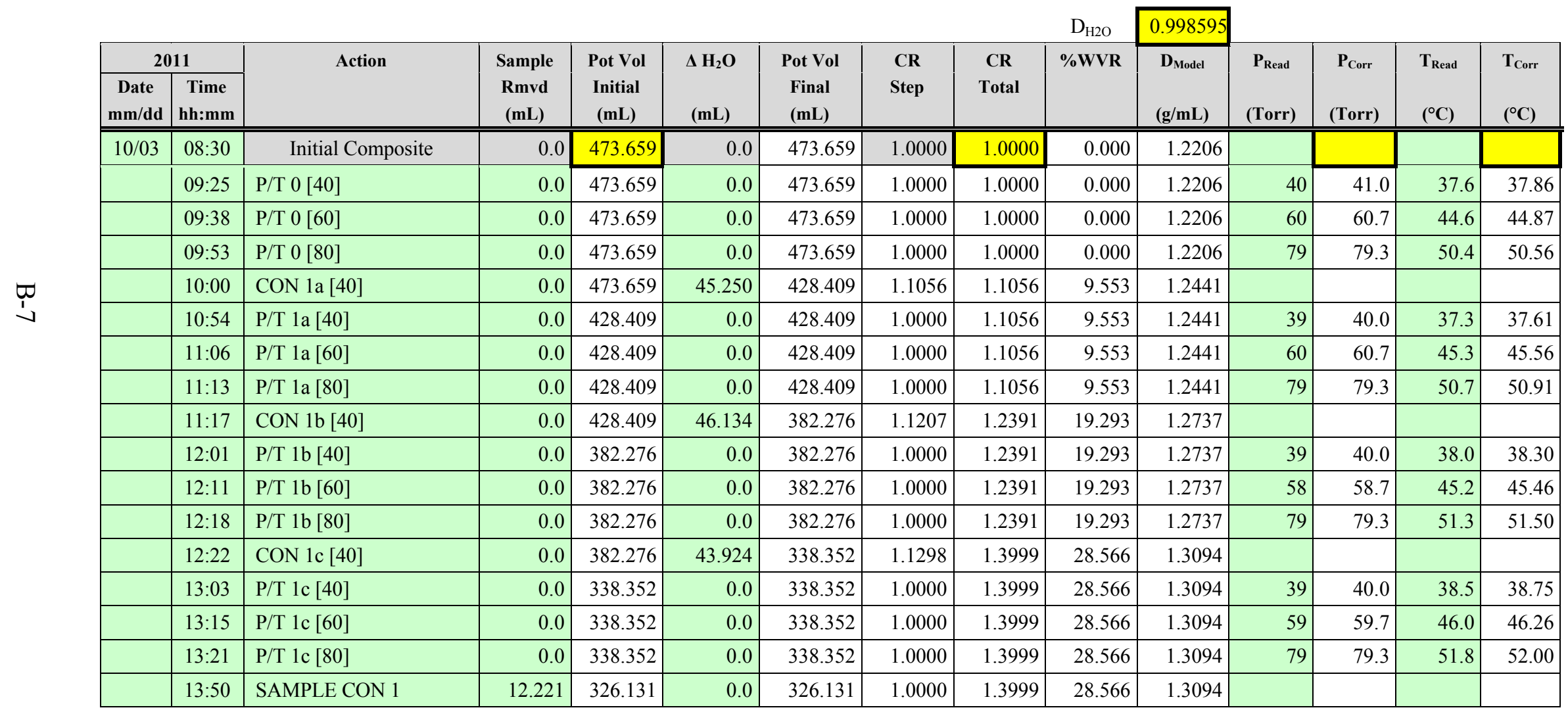


Table B-2. Revised Tank 241-AP-107 Boildown Hot Cell Data Log. (3 sheets)

\begin{tabular}{|c|c|c|c|c|c|c|c|c|c|c|c|c|c|c|}
\hline & & & & & & & & & $\mathrm{D}_{\mathrm{H} 2 \mathrm{O}}$ & 0.998595 & & & & \\
\hline 20 & 11 & Action & Sample & Pot Vol & $\Delta \mathbf{H}_{2} \mathbf{O}$ & Pot Vol & CR & CR & \%WVR & $\mathbf{D}_{\text {Model }}$ & $\mathbf{P}_{\text {Read }}$ & $\mathbf{P}_{\text {Corr }}$ & $T_{\text {Read }}$ & $\mathbf{T}_{\text {Corr }}$ \\
\hline $\begin{array}{c}\text { Date } \\
\mathbf{m m} / \mathbf{d d}\end{array}$ & \begin{tabular}{|c|c} 
Time \\
hh:mm
\end{tabular} & & $\begin{array}{c}\text { Rmvd } \\
(\mathrm{mL})\end{array}$ & $\begin{array}{c}\text { Initial } \\
(\mathrm{mL})\end{array}$ & (mL) & $\begin{array}{l}\text { Final } \\
(\mathrm{mL}) \\
\end{array}$ & Step & Total & & $(\mathrm{g} / \mathrm{mL})$ & (Torr) & (Torr) & $\left({ }^{\circ} \mathrm{C}\right)$ & $\left({ }^{\circ} \mathrm{C}\right)$ \\
\hline $10 / 04$ & 07:30 & $\mathrm{P} / \mathrm{T} 1 \mathrm{~d}[40]$ & 0.0 & 326.131 & 0.0 & 326.131 & 1.0000 & 1.3999 & 28.566 & 1.3094 & 38 & 39.0 & 37.7 & 38.01 \\
\hline & 07:45 & $\mathrm{P} / \mathrm{T} 1 \mathrm{~d}[60]$ & 0.0 & 326.131 & 0.0 & 326.131 & 1.0000 & 1.3999 & 28.566 & 1.3094 & 58 & 58.7 & 45.7 & 45.96 \\
\hline & $07: 55$ & $\mathrm{P} / \mathrm{T}$ 1d [80] & 0.0 & 326.131 & 0.0 & 326.131 & 1.0000 & 1.3999 & 28.566 & 1.3094 & 79 & 79.3 & 51.8 & 52.00 \\
\hline & $07: 58$ & CON 2 [80] & 0.0 & 326.131 & 42.598 & 283.533 & 1.1502 & 1.6102 & 37.897 & 1.3561 & & & & \\
\hline & 08:40 & $\mathrm{P} / \mathrm{T} 2$ [80] & 0.0 & 283.533 & 0.0 & 283.533 & 1.0000 & 1.6102 & 37.897 & 1.3561 & 79 & 79.3 & 52.8 & 52.98 \\
\hline & 08:44 & $\mathrm{P} / \mathrm{T} 2$ [60] & 0.0 & 283.533 & 0.0 & 283.533 & 1.0000 & 1.6102 & 37.897 & 1.3561 & 60 & 60.7 & 47.2 & 47.45 \\
\hline & 08:48 & $\mathrm{P} / \mathrm{T} 2$ [40] & 0.0 & 283.533 & 0.0 & 283.533 & 1.0000 & 1.6102 & 37.897 & 1.3561 & 39 & 40.0 & 39.3 & 39.60 \\
\hline & 09:15 & SAMPLE CON 2 & 12.995 & 270.538 & 0.0 & 270.538 & 1.0000 & 1.6102 & 37.897 & 1.3561 & & & & \\
\hline & 09:30 & CON $3[40]$ & 0.0 & 270.538 & 21.417 & 249.121 & 1.0860 & 1.7487 & 42.813 & 1.3869 & & & & \\
\hline & 09:54 & $\mathrm{P} / \mathrm{T} 3[40]$ & 0.0 & 249.121 & 0.0 & 249.121 & 1.0000 & 1.7487 & 42.813 & 1.3869 & 39 & 40.0 & 40.0 & 40.30 \\
\hline & $10: 02$ & $\mathrm{P} / \mathrm{T} 3[60]$ & 0.0 & 249.121 & 0.0 & 249.121 & 1.0000 & 1.7487 & 42.813 & 1.3869 & 59 & \begin{tabular}{ll|}
59.7 \\
\end{tabular} & 47.6 & 47.84 \\
\hline & 10:07 & $\mathrm{P} / \mathrm{T} 3[80]$ & 0.0 & 249.121 & 0.0 & 249.121 & 1.0000 & 1.7487 & 42.813 & 1.3869 & 79 & 79.3 & 53.4 & 53.57 \\
\hline & $10: 30$ & SAMPLE CON 3 & 11.745 & 237.376 & 0.0 & 237.376 & 1.0000 & 1.7487 & 42.813 & 1.3869 & & & & \\
\hline & $10: 45$ & CON $4[80]$ & 0.0 & 237.376 & 18.743 & 218.633 & 1.0857 & 1.8986 & 47.329 & 1.4202 & & & & \\
\hline & $11: 16$ & $\mathrm{P} / \mathrm{T} 4[80]$ & 0.0 & 218.633 & 0.0 & 218.633 & 1.0000 & 1.8986 & 47.329 & 1.4202 & 79 & 79.3 & 54.4 & 54.56 \\
\hline & $11: 20$ & $\mathrm{P} / \mathrm{T} 4[60]$ & 0.0 & 218.633 & 0.0 & 218.633 & 1.0000 & 1.8986 & 47.329 & 1.4202 & 60 & 60.7 & 48.9 & 49.08 \\
\hline & $11: 28$ & $\mathrm{P} / \mathrm{T} 4[40]$ & 0.0 & 218.633 & 0.0 & 218.633 & 1.0000 & 1.8986 & 47.329 & 1.4202 & 40 & 41.0 & 41.2 & 41.49 \\
\hline & $11: 36$ & SAMPLE CON 4 & 11.969 & 206.664 & 0.0 & 206.664 & 1.0000 & 1.8986 & 47.329 & 1.4202 & & & & \\
\hline & $11: 50$ & CON $5[40]$ & 0.0 & 206.664 & 16.679 & 189.984 & 1.0878 & 2.0652 & 51.580 & 1.4572 & & & & \\
\hline & $12: 15$ & $\mathrm{P} / \mathrm{T} 5$ [40] & 0.0 & 189.984 & 0.0 & 189.984 & 1.0000 & 2.0652 & 51.580 & 1.4572 & 40 & 41.0 & 42.3 & 42.58 \\
\hline & $12: 20$ & $\mathrm{P} / \mathrm{T} 5[60]$ & 0.0 & 189.984 & 0.0 & 189.984 & 1.0000 & 2.0652 & 51.580 & 1.4572 & 60 & 60.7 & 49.7 & 49.92 \\
\hline & $12: 23$ & $\mathrm{P} / \mathrm{T} 5[80]$ & 0.0 & 189.984 & 0.0 & 189.984 & 1.0000 & 2.0652 & 51.580 & 1.4572 & 79 & 79.3 & 55.2 & 55.35 \\
\hline & $12: 35$ & SAMPLE CON 5 & 12.428 & 177.556 & 0.0 & 177.556 & 1.0000 & 2.0652 & 51.580 & 1.4572 & & & & \\
\hline
\end{tabular}


Table B-2. Revised Tank 241-AP-107 Boildown Hot Cell Data Log. (3 sheets)

\begin{tabular}{|c|c|c|c|c|c|c|c|c|c|c|c|c|c|c|}
\hline & & & & & & & & & $\mathrm{D}_{\mathrm{H} 2 \mathrm{O}}$ & 0.998595 & & & & \\
\hline 20 & 11 & Action & Sample & Pot Vol & $\Delta \mathrm{H}_{2} \mathrm{O}$ & Pot Vol & CR & CR & $\% W V R$ & $\mathbf{D}_{\text {Model }}$ & $\mathbf{P}_{\text {Read }}$ & $\mathbf{P}_{\text {Corr }}$ & $T_{\text {Read }}$ & $\mathbf{T}_{\text {Corr }}$ \\
\hline $\begin{array}{c}\text { Date } \\
\mathbf{m m} / \mathbf{d d} \\
\end{array}$ & $\begin{array}{c}\begin{array}{c}\text { Time } \\
\text { hh:mm }\end{array} \\
\end{array}$ & & $\begin{array}{c}\text { Rmvd } \\
(\mathrm{mL})\end{array}$ & $\begin{array}{c}\text { Initial } \\
(\mathrm{mL}) \\
\end{array}$ & (mL) & $\begin{array}{l}\text { Final } \\
(\mathrm{mL}) \\
\end{array}$ & Step & Total & & $(\mathrm{g} / \mathrm{mL})$ & (Torr) & (Torr) & $\left({ }^{\circ} \mathrm{C}\right)$ & $\left({ }^{\circ} \mathrm{C}\right)$ \\
\hline $10 / 04$ & $13: 00$ & CON 6 [80] & 0.0 & 177.556 & 15.083 & 162.473 & 1.0928 & 2.2570 & 55.693 & 1.4998 & & & & \\
\hline & $13: 36$ & P/T 6 [80] & 0.0 & 162.473 & 0.0 & 162.473 & 1.0000 & 2.2570 & 55.693 & 1.4998 & 79 & 79.3 & 56.7 & 56.83 \\
\hline & $13: 40$ & $\mathrm{P} / \mathrm{T} 6[60]$ & 0.0 & 162.473 & 0.0 & 162.473 & 1.0000 & 2.2570 & 55.693 & 1.4998 & 59 & 59.7 & 50.6 & 50.81 \\
\hline & $13: 44$ & $\mathrm{P} / \mathrm{T} 6[40]$ & 0.0 & 162.473 & 0.0 & 162.473 & 1.0000 & 2.2570 & 55.693 & 1.4998 & 39 & 40.0 & 42.7 & 42.98 \\
\hline & $14: 02$ & SAMPLE CON 6 & 12.271 & 150.202 & 0.0 & 150.202 & 1.0000 & 2.2570 & 55.693 & 1.4998 & & & & \\
\hline & 14:18 & CON $7[40]$ & 0.0 & 150.202 & 11.622 & 138.580 & 1.0839 & 2.4463 & 59.121 & 1.5418 & & & & \\
\hline & $14: 37$ & $\mathrm{P} / \mathrm{T} 7[40]$ & 0.0 & 138.580 & 0.0 & 138.580 & 1.0000 & 2.4463 & 59.121 & 1.5418 & 39 & 40.0 & 43.1 & 43.38 \\
\hline & $14: 41$ & $\mathrm{P} / \mathrm{T} 7[60]$ & 0.0 & 138.580 & 0.0 & 138.580 & 1.0000 & 2.4463 & 59.121 & 1.5418 & 60 & 60.7 & 51.3 & 51.50 \\
\hline & $14: 47$ & $\mathrm{P} / \mathrm{T} 7[80]$ & 0.0 & 138.580 & 0.0 & 138.580 & 1.0000 & 2.4463 & 59.121 & 1.5418 & 80 & 80.3 & 57.0 & 57.12 \\
\hline & 15:04 & SAMPLE CON 7 & 13.386 & 125.194 & 0.0 & 125.194 & 1.0000 & 2.4463 & 59.121 & 1.5418 & & & & \\
\hline & $15: 34$ & DIL 1 & 0.0 & 125.194 & -120.209 & 245.403 & 0.5102 & 1.2480 & 19.870 & 1.2757 & & & & \\
\hline & $16: 00$ & $\mathrm{P} / \mathrm{T} 8$ [60] & 0.0 & 245.403 & 0.0 & 245.403 & 1.0000 & 1.2480 & 19.870 & 1.2757 & 59 & 59.7 & 45.6 & 45.86 \\
\hline & $16: 12$ & SAMPLE DIL 1 & 12.850 & 232.553 & 0.0 & 232.553 & 1.0000 & 1.2480 & 19.870 & 1.2757 & & & & \\
\hline & $16: 40$ & DIL 2 & 0.0 & 232.553 & -16.223 & 248.776 & 0.9348 & 1.1666 & 14.280 & 1.2576 & & & & \\
\hline & $16: 59$ & $\mathrm{P} / \mathrm{T} 9[60]$ & 0.0 & 248.776 & 0.0 & 248.776 & 1.0000 & 1.1666 & 14.280 & 1.2576 & 59 & 59.7 & 45.4 & 45.66 \\
\hline & 17:07 & SAMPLE DIL 2 & 13.057 & 235.719 & 0.0 & 235.719 & 1.0000 & 1.1666 & 14.280 & 1.2576 & & & & \\
\hline & $17: 37$ & DIL 3 & 0.0 & 235.719 & -18.156 & 253.874 & 0.9285 & 1.0832 & 7.678 & 1.2391 & & & & \\
\hline & $17: 54$ & $\mathrm{P} / \mathrm{T} 10[60]$ & 0.0 & 253.874 & 0.0 & 253.874 & 1.0000 & 1.0832 & 7.678 & 1.2391 & 59 & 59.7 & 45.0 & 45.26 \\
\hline & 18:05 & SAMPLE DIL 3 & 12.780 & 241.094 & 0.0 & 241.094 & 1.0000 & 1.0832 & 7.678 & 1.2391 & & & & \\
\hline
\end{tabular}




\section{REFERENCES}

SVF-1543, 2008, "CH2M HILL Spreadsheet Verification and Release Form," Rev. 0, CH2M HILL Hanford Group, Inc., Richland, Washington.

RPP-38843, 2008, Spreadsheet Description Document for Boildown Test Data Spreadsheet, Rev. 0, CH2M HILL Hanford Group, Inc., Richland, Washington. 
LAB-RPT-12-00008, R0

\section{ATTACHMENT C}

PHOTOGRAPHS OF BOILDOWN SAMPLES 
Figure C-1. Sample CON 1 Collected after Concentration to $27.74 \% \mathrm{WVR}^{18^{\circ} \mathrm{C}}$. (enlarged $\left.\approx 25 \%\right)$

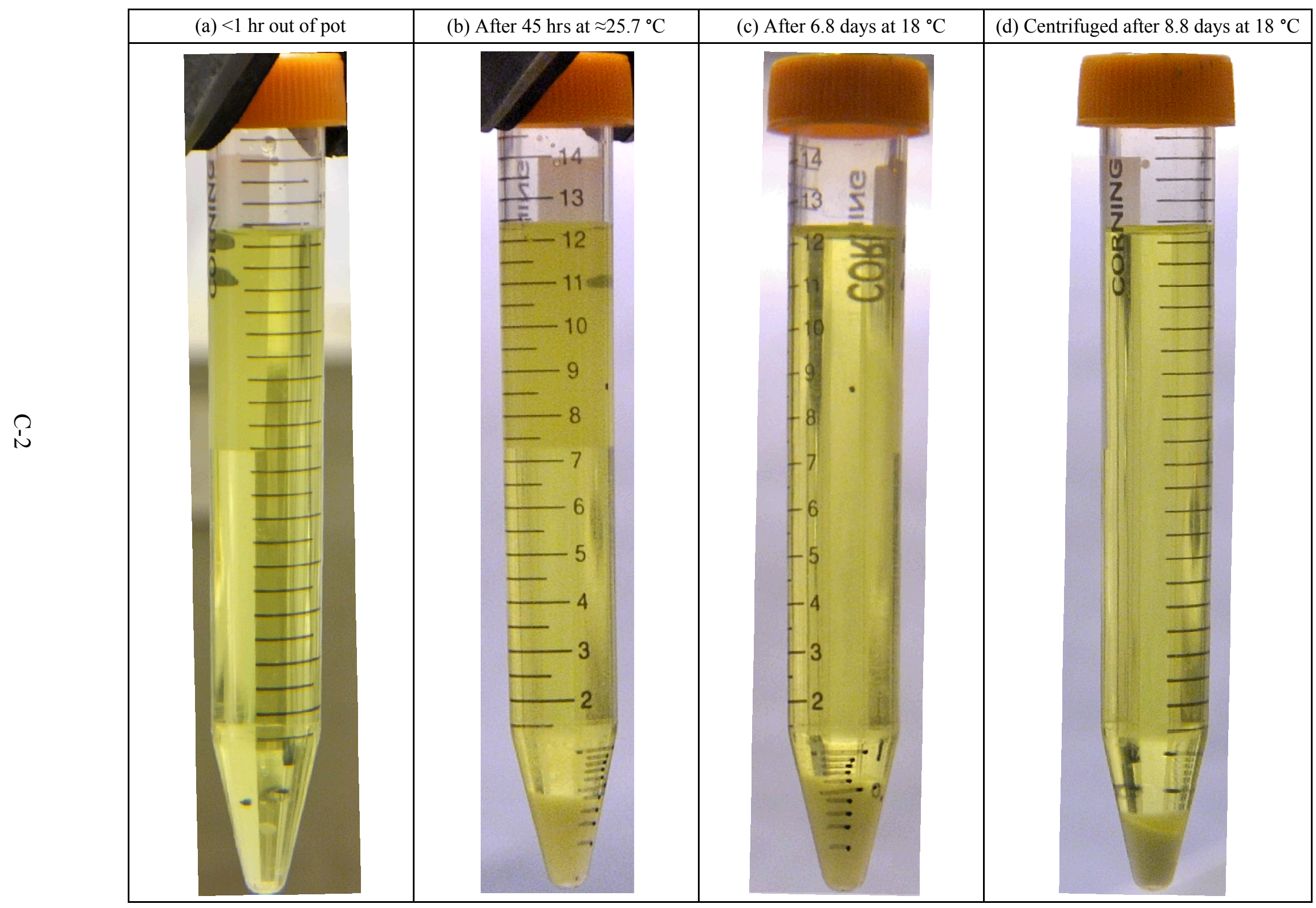

5
0
1
0
0
1
1
1
8
8
8
0
0
0 
Figure C-2. Sample CON 2 Collected after Concentration to $36.88 \% \mathrm{WVR}^{18}{ }^{\circ} \mathrm{C}$. (enlarged $\left.\approx 25 \%\right)$

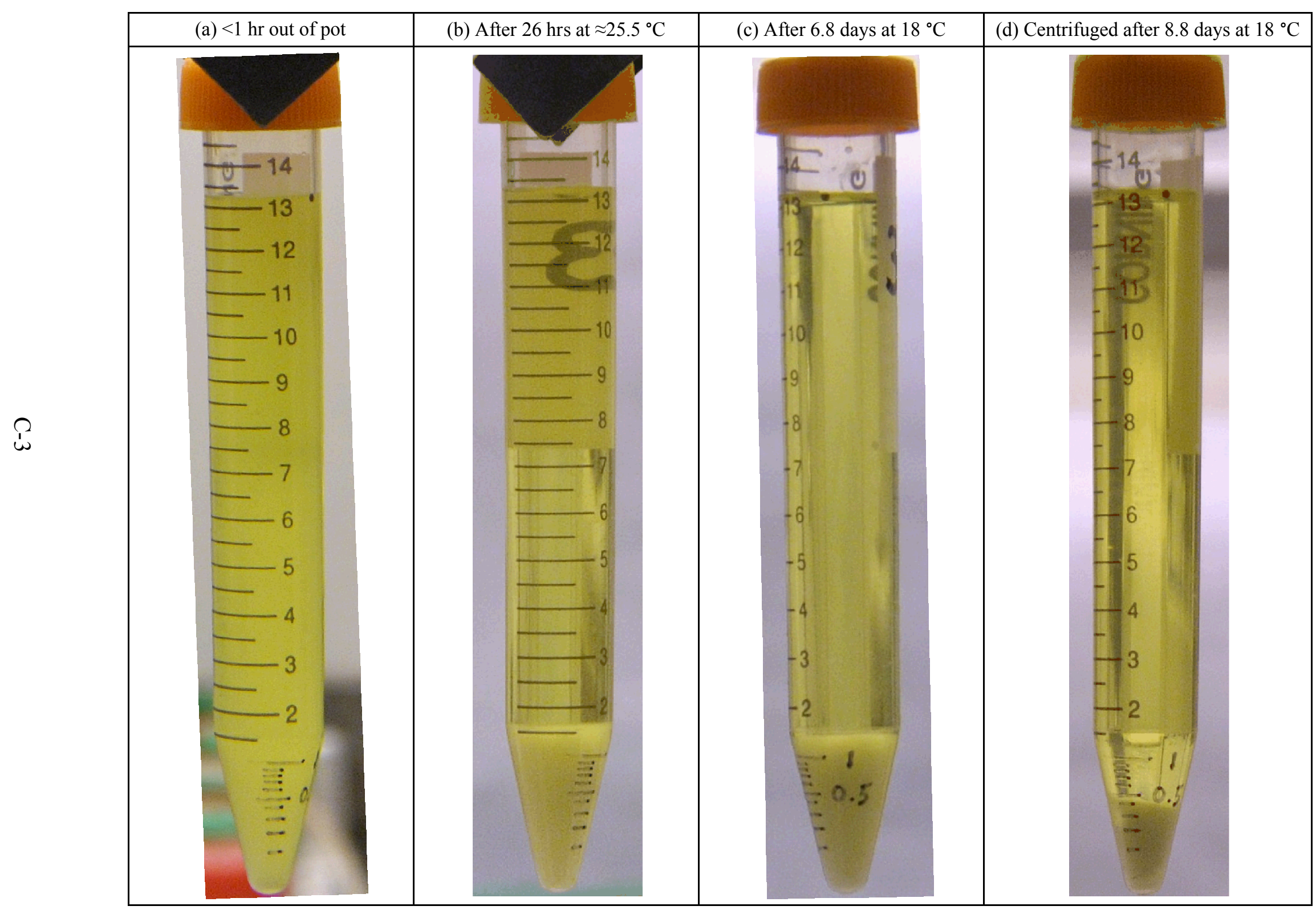

5
0
1
0
7
1
1
1
8
8
8
0
0
0 
Figure C-3. Sample CON 3 Collected after Concentration to $41.58 \% \mathrm{WVR}^{18}{ }^{\circ} \mathrm{C}$. (enlarged $\approx 25 \%$ )

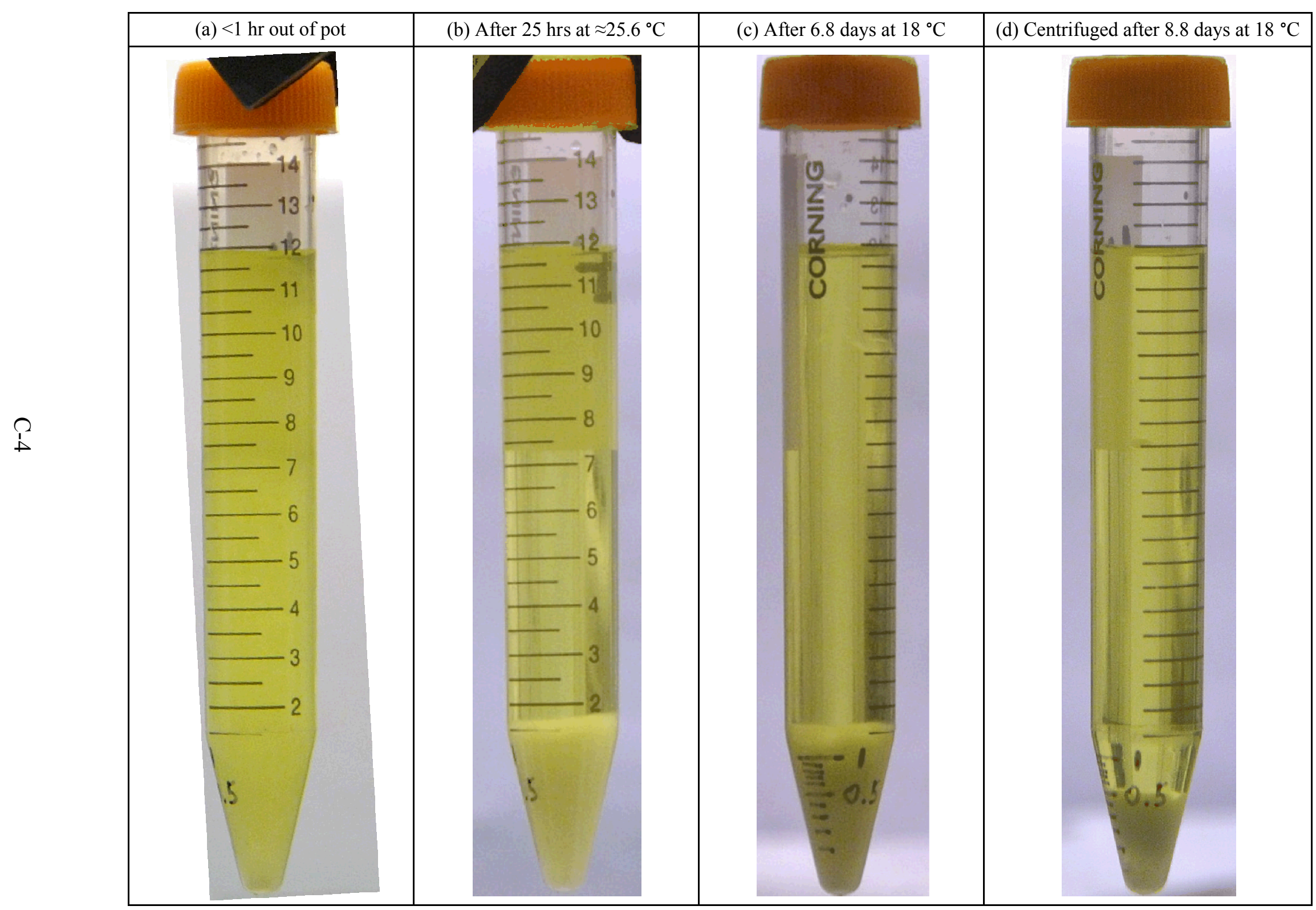


Figure C-4. Sample CON 4 Collected after Concentration to $46.05 \% \mathrm{WVR}^{18^{\circ} \mathrm{C}}$. (enlarged $\left.\approx 25 \%\right)$

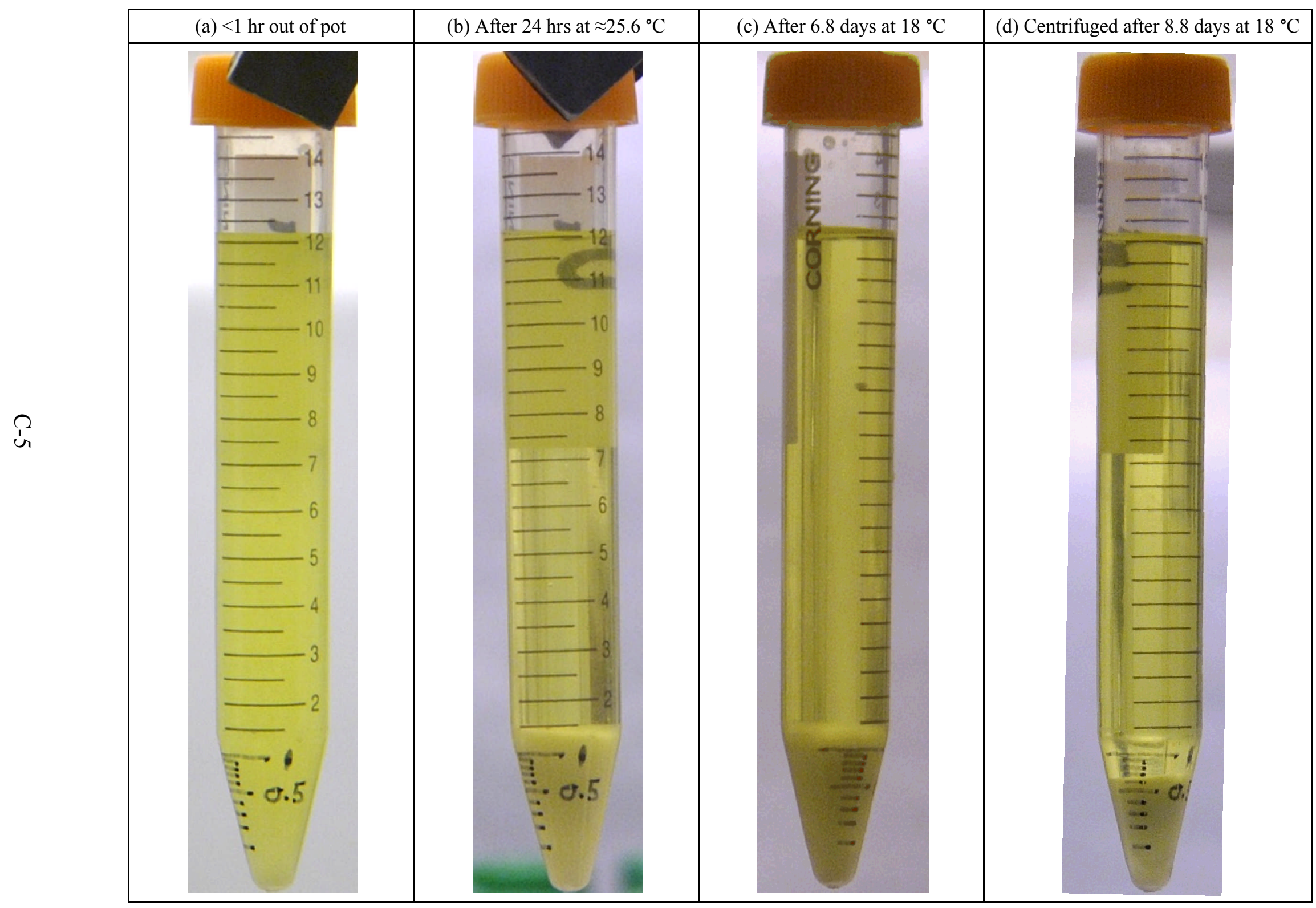

5
0
1
0
7
1
1
1
8
8
0
0
0
0 
Figure C-5. Sample CON 5 Collected after Concentration to $50.15 \% \mathrm{WVR}^{18^{\circ} \mathrm{C}}$. (enlarged $\left.\approx 25 \%\right)$

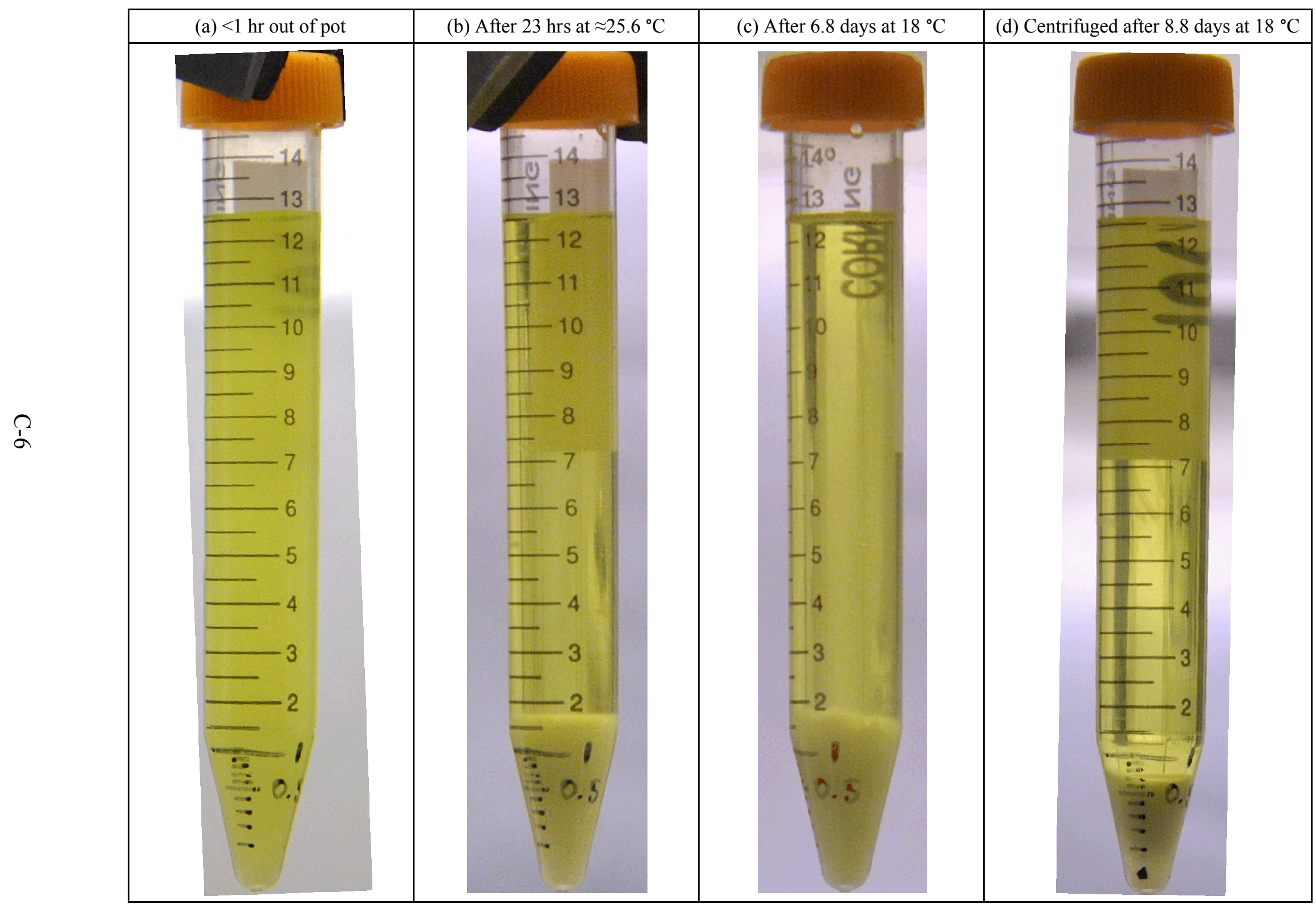

5
0
1
0
7
1
1
1
8
8
0
0
0
0 
Figure C-6. Sample CON 6 Collected after Concentration to $54.04 \% \mathrm{WVR}^{18}{ }^{\circ} \mathrm{C}$. (enlarged $\left.\approx 25 \%\right)$

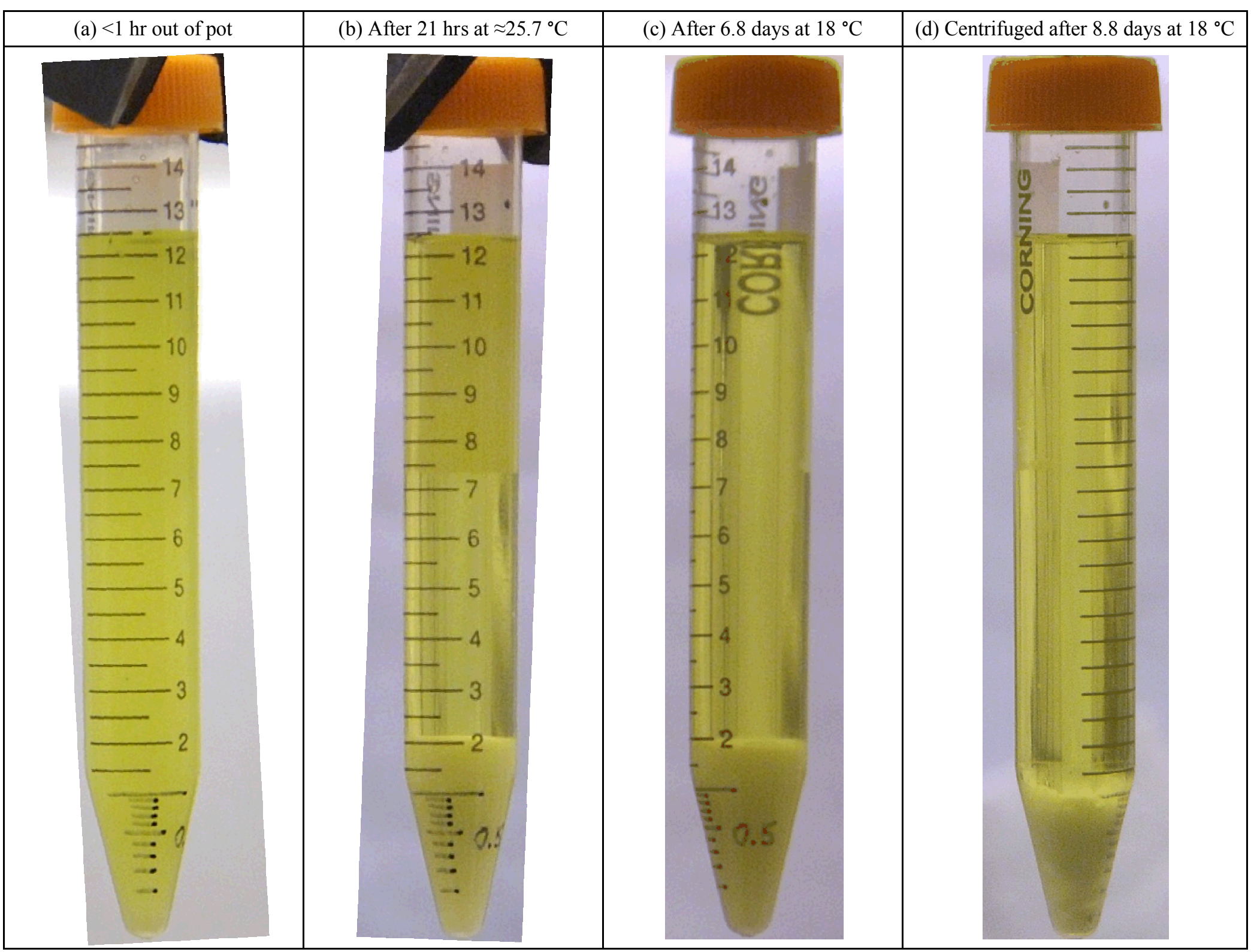

5
0
1
0
7
1
1
1
8
8
8
0
0
0 
Figure C-7. Sample CON 7 Collected after Concentration to $57.47 \% \mathrm{WVR}^{18^{\circ} \mathrm{C}}$. (enlarged $\left.\approx 25 \%\right)$

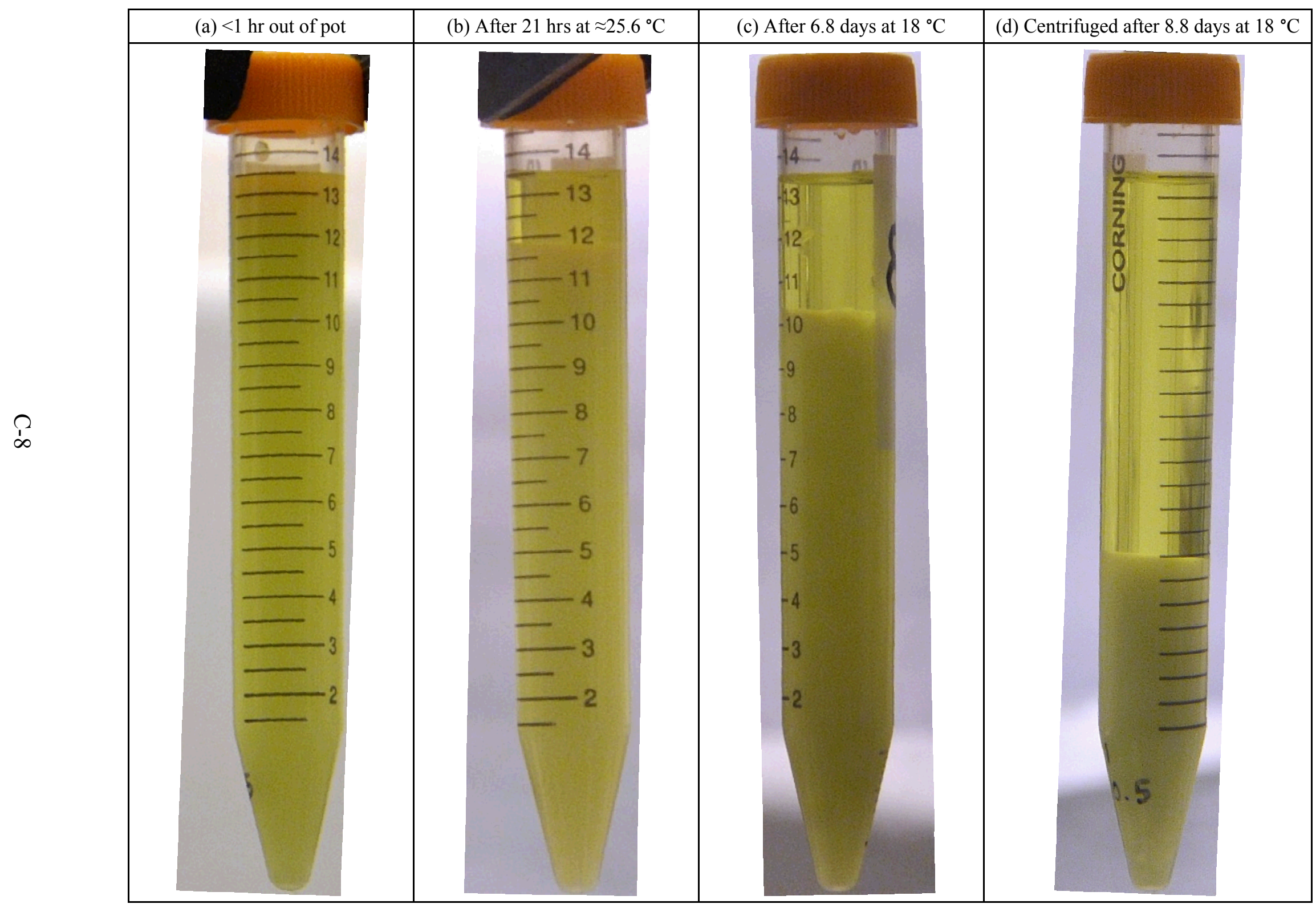

5
0
1
0
7
1
1
1
8
8
0
0
0
0 
Figure C-8. Sample DIL 1 Collected after Dilution of End-point Slurry to $19.90 \% \mathrm{WVR}^{18}{ }^{\circ} \mathrm{C}$. (enlarged $\left.\approx 25 \%\right)$

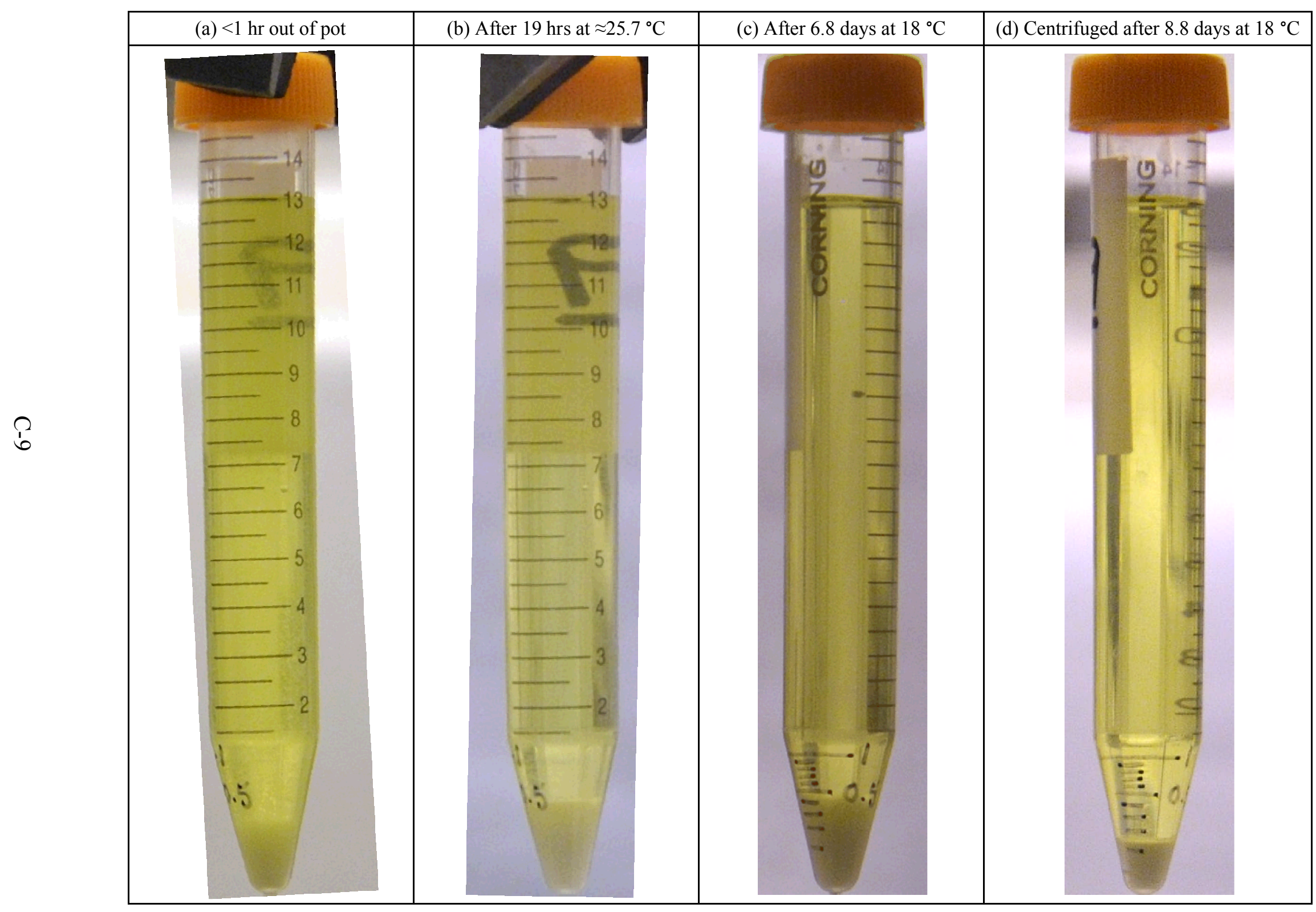


Figure C-9. Sample DIL 2 Collected after Dilution of End-point Slurry to $14.66 \% \mathrm{WVR}^{18}{ }^{\circ} \mathrm{C}$. (enlarged $\left.\approx 25 \%\right)$

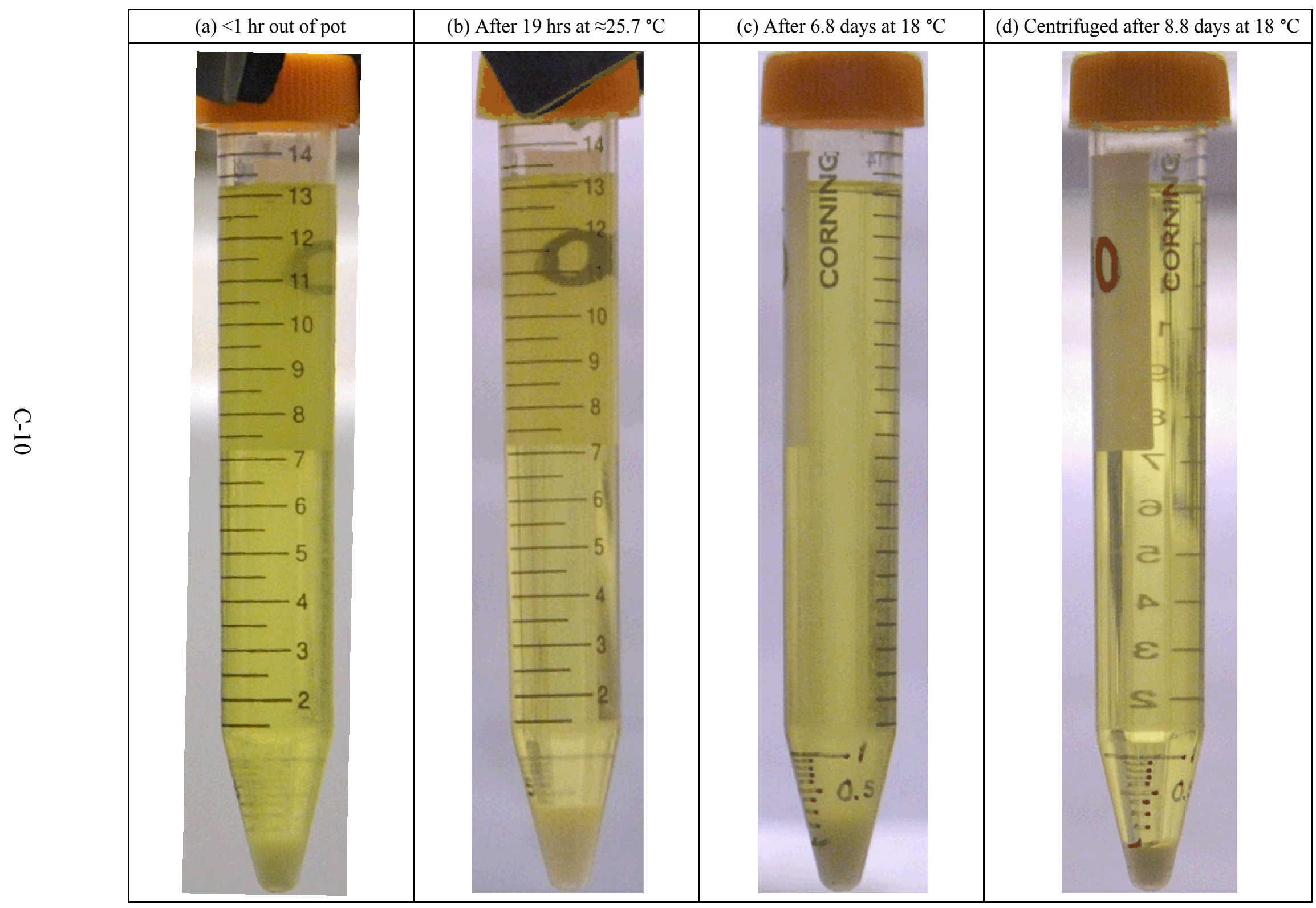

5
7
1
0
0
7
1
1
1
8
8
0
0
0 
Figure C-10. Sample DIL 3 Collected after Dilution of End-point Slurry to $8.37 \% \mathrm{WVR}^{18}{ }^{\circ} \mathrm{C}$. $($ enlarged $\approx 25 \%)$

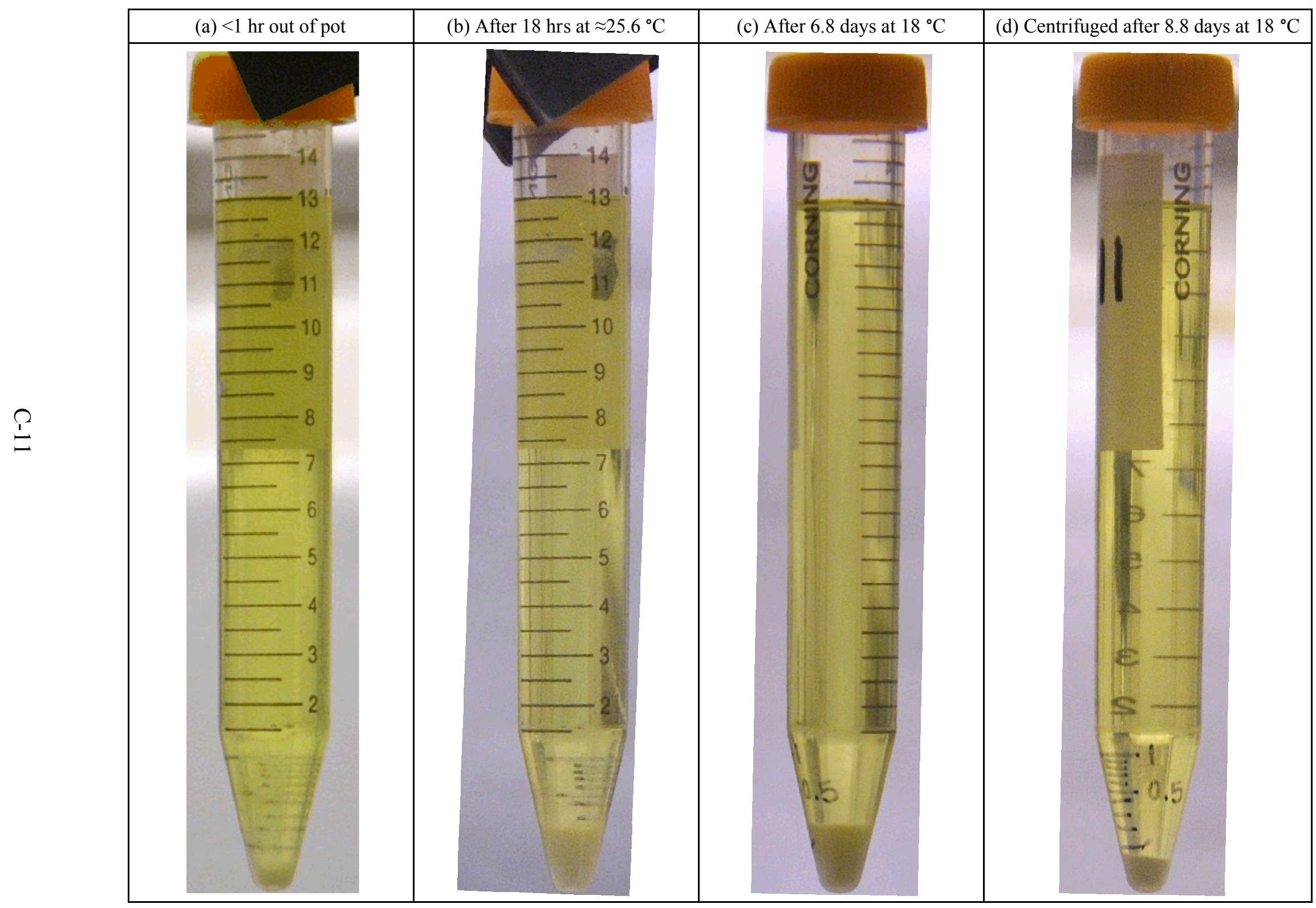


LAB-RPT-12-00008, R0

\section{ATTACHMENT D}

LABORATORY ANALYSIS RESULTS 


\section{ATTACHMENT D LABORATORY ANALYSIS RESULTS}

Transcripts of the data summary reports for the physicochemical analyses of the AP-107 boildown sample liquids are presented in this attachment. All analyses were performed at the 222-S Laboratory by ATL personnel. The following analyses were performed:

\begin{tabular}{|c|c|}
\hline $\begin{array}{l}\text { Component } \\
\text { (Method) }\end{array}$ & $\begin{array}{l}\text { 222-S Procedure } \\
\text { Specific Analytes }\end{array}$ \\
\hline $\begin{array}{l}\text { Specific gravity }(\mathrm{SpG}) \\
\quad \text { (gravimetric) }\end{array}$ & LA-510-112, Rev/Mod I-0 \\
\hline $\begin{array}{l}\text { Total inorganic carbon / total organic carbon } \\
\text { (acid-sparging/persulfate-oxidation coulometry) }\end{array}$ & LA-342-100, Rev/Mod J-0 \\
\hline $\begin{array}{l}\text { Anions } \\
\quad \text { (ion chromatography) }\end{array}$ & $\begin{array}{l}\mathrm{LA}-533-115, \mathrm{Rev} / \mathrm{Mod} \mathrm{J}-0 \\
\mathrm{Br}^{-}, \mathrm{Cl}^{-}, \mathrm{F}^{-}, \mathrm{NO}_{2}^{-}, \mathrm{NO}_{3}^{-}, \mathrm{PO}_{4}{ }^{3-} \text {, and } \mathrm{SO}_{4}{ }^{2-} \text {, and } \\
\text { Small organic anions: formate, acetate, oxalate, and } \\
\text { glycolate }\end{array}$ \\
\hline $\begin{array}{l}\text { Elemental components } \\
\quad \text { (inductively coupled plasma-atomic emission) }\end{array}$ & $\begin{array}{l}\text { LA-505-161, Rev. J-0-A } \\
\text { Priority analytes: } \mathrm{Na}, \mathrm{Al}, \mathrm{Si}, \mathrm{P}, \mathrm{S}, \mathrm{K}, \mathrm{Ca} \text {, and } \mathrm{Cr} \text {. All } \\
\text { others reported as opportunistic analytes. }\end{array}$ \\
\hline $\begin{array}{l}\text { Hydroxide } \\
\quad \text { (potentiometric titration) }\end{array}$ & LA-211-102, Rev/Mod I-1 \\
\hline $\begin{array}{l}\text { Total carbon } \\
\quad \text { (combustion-coulometry) }\end{array}$ & LA-344-105, Rev/Mod J-0 \\
\hline
\end{tabular}

The following abbreviations are in the header for each data table:

\begin{tabular}{|l|l|}
\hline Std \%-Rec & Standard percent recovery \\
\hline RPD & Relative recent difference \\
\hline Spk \%-Rec & Spike percent recovery \\
\hline Det Limit & Minimum detection limit \\
\hline Qual Flags & Quality assurance data qualifier codes \\
\hline
\end{tabular}

The quality assurance data 'flags' in the right-most column of the data summary tables are defined as follows:

\begin{tabular}{|l|l|}
\hline $\mathrm{J}$ & Estimated \\
\hline $\mathrm{U}$ & Less than detection limit \\
\hline
\end{tabular}


Table D-1. Tank 241-AP-107 Boildown Composite (Sample CON 0). (2 sheets) Sample(s): S11T011048 and S11T011049 (Test Samples CON 0A and CON 0B)

Sample Group: 20111225

\begin{tabular}{|c|c|c|c|c|c|c|c|c|c|c|c|}
\hline Sample \# & Analyte & Unit & $\begin{array}{c}\text { Std } \\
\%-\operatorname{Rec}\end{array}$ & Blank & Result & Duplicate & Average & RPD & $\begin{array}{c}\text { Spk } \\
\% \text { o-Rec }\end{array}$ & $\begin{array}{c}\text { Det } \\
\text { Limit }\end{array}$ & $\begin{array}{l}\text { Qual } \\
\text { Flags }\end{array}$ \\
\hline S11T011048 & Fluoride & $\mathrm{ug} / \mathrm{mL}$ & 103 & $<1.61 \mathrm{E}-03$ & 469 & 469 & 469 & 0.0575 & 104 & 1.61 & \\
\hline S11T011048 & Glycolate & $\mathrm{ug} / \mathrm{mL}$ & 101 & $<9.37 \mathrm{E}-03$ & 175 & 169 & 172 & 3.45 & 102 & 9.37 & \\
\hline S11T011048 & Acetate & $\mathrm{ug} / \mathrm{mL}$ & 101 & $<6.04 \mathrm{E}-03$ & 204 & 185 & 194 & 9.48 & 101 & 6.04 & \\
\hline S11T011048 & Formate & $\mathrm{ug} / \mathrm{mL}$ & 101 & $<4.67 \mathrm{E}-03$ & 651 & 637 & 644 & 2.26 & 101 & 4.67 & \\
\hline S11T011048 & Chloride & $\mathrm{ug} / \mathrm{mL}$ & 101 & 0.0131 & $1.41 \mathrm{E}+03$ & $1.39 \mathrm{E}+03$ & $1.40 \mathrm{E}+03$ & 1.36 & 99.8 & 9.98 & \\
\hline S11T011048 & Nitrite & $\mathrm{ug} / \mathrm{mL}$ & 100 & $<0.0192$ & $3.04 \mathrm{E}+04$ & $3.02 \mathrm{E}+04$ & $3.03 \mathrm{E}+04$ & 0.456 & 101 & 192 & \\
\hline S11T011048 & Sulfate & $\mathrm{ug} / \mathrm{mL}$ & 102 & $<0.0187$ & $9.09 \mathrm{E}+03$ & $9.08 \mathrm{E}+03$ & $9.08 \mathrm{E}+03$ & 0.0609 & 99.5 & 18.7 & \\
\hline S11T011048 & Oxalate & $\mathrm{ug} / \mathrm{mL}$ & 102 & $<0.0231$ & $1.62 \mathrm{E}+03$ & $1.61 \mathrm{E}+03$ & $1.61 \mathrm{E}+03$ & 0.547 & 96.7 & 23.1 & \\
\hline S11T011048 & Bromide & $\mathrm{ug} / \mathrm{mL}$ & 101 & $<0.0580$ & $<58.0$ & $<58.0$ & $\mathrm{n} / \mathrm{a}$ & $\mathrm{n} / \mathrm{a}$ & 96.3 & 58.0 & $\mathrm{U}$ \\
\hline S11T011048 & Nitrate & $\mathrm{ug} / \mathrm{mL}$ & 100 & 0.0709 & $1.19 \mathrm{E}+05$ & $1.18 \mathrm{E}+05$ & $1.18 \mathrm{E}+05$ & 0.679 & 100 & 208 & \\
\hline S11T011048 & Phosphate & $\mathrm{ug} / \mathrm{mL}$ & 101 & $<0.0167$ & $2.91 \mathrm{E}+03$ & $2.90 \mathrm{E}+03$ & $2.90 \mathrm{E}+03$ & 0.238 & 101 & 16.7 & \\
\hline S11T011048 & Total organic carbon & $\mathrm{ug} / \mathrm{mL}$ & 97.2 & $<20.0$ & $1.70 \mathrm{E}+03$ & $1.06 \mathrm{E}+03$ & $1.38 \mathrm{E}+03$ & 46.4 & 85.8 & 400 & $\mathrm{~J}$ \\
\hline S11T011048 & Total inorganic carbon & $\mathrm{ug} / \mathrm{mL}$ & 97.9 & $<7.00$ & $5.82 \mathrm{E}+03$ & $5.81 \mathrm{E}+03$ & $5.82 \mathrm{E}+03$ & 0.172 & 96.6 & 140 & \\
\hline S11T011048 & Total carbon & $\mathrm{ug} / \mathrm{mL}$ & 97.2 & $<5.00$ & $7.22 \mathrm{E}+03$ & $7.12 \mathrm{E}+03$ & $7.17 \mathrm{E}+03$ & 1.39 & 99.9 & 55.0 & \\
\hline S11T011049 & Silver & $\mathrm{ug} / \mathrm{mL}$ & 98.6 & $\mathrm{n} / \mathrm{a}$ & $<12.5$ & $\mathrm{n} / \mathrm{a}$ & $\mathrm{n} / \mathrm{a}$ & $\mathrm{n} / \mathrm{a}$ & $\mathrm{n} / \mathrm{a}$ & 12.5 & \\
\hline S11T011049 & Aluminum & $\mathrm{ug} / \mathrm{mL}$ & 101 & $<0.0300$ & $4.38 \mathrm{E}+03$ & $4.46 \mathrm{E}+03$ & $4.42 \mathrm{E}+03$ & 1.70 & 99.4 & 75.0 & \\
\hline S11T011049 & Arsenic & $\mathrm{ug} / \mathrm{mL}$ & 100 & $\mathrm{n} / \mathrm{a}$ & $<125$ & $\mathrm{n} / \mathrm{a}$ & $\mathrm{n} / \mathrm{a}$ & $\mathrm{n} / \mathrm{a}$ & $\mathrm{n} / \mathrm{a}$ & 125 & \\
\hline S11T011049 & Boron & $\mathrm{ug} / \mathrm{mL}$ & 99.3 & $\mathrm{n} / \mathrm{a}$ & $<75.0$ & $\mathrm{n} / \mathrm{a}$ & $\mathrm{n} / \mathrm{a}$ & $\mathrm{n} / \mathrm{a}$ & $\mathrm{n} / \mathrm{a}$ & 75.0 & \\
\hline S11T011049 & Barium & $\mathrm{ug} / \mathrm{mL}$ & 101 & $\mathrm{n} / \mathrm{a}$ & $<7.50$ & $\mathrm{n} / \mathrm{a}$ & $\mathrm{n} / \mathrm{a}$ & $\mathrm{n} / \mathrm{a}$ & $\mathrm{n} / \mathrm{a}$ & 7.50 & \\
\hline S11T011049 & Beryllium & $\mathrm{ug} / \mathrm{mL}$ & 98.9 & $\mathrm{n} / \mathrm{a}$ & $<2.50$ & $\mathrm{n} / \mathrm{a}$ & $\mathrm{n} / \mathrm{a}$ & $\mathrm{n} / \mathrm{a}$ & $\mathrm{n} / \mathrm{a}$ & 2.50 & \\
\hline S11T011049 & Bismuth & $\mathrm{ug} / \mathrm{mL}$ & 100 & $\mathrm{n} / \mathrm{a}$ & $<250$ & $\mathrm{n} / \mathrm{a}$ & $\mathrm{n} / \mathrm{a}$ & $\mathrm{n} / \mathrm{a}$ & $\mathrm{n} / \mathrm{a}$ & 250 & \\
\hline S11T011049 & Calcium & $\mathrm{ug} / \mathrm{mL}$ & 101 & $<0.0500$ & $<125$ & $<125$ & $\mathrm{n} / \mathrm{a}$ & $n / a$ & 95.3 & 125 & $\mathrm{U}$ \\
\hline S11T011049 & Cadmium & $\mathrm{ug} / \mathrm{mL}$ & 102 & $\mathrm{n} / \mathrm{a}$ & $<12.5$ & $\mathrm{n} / \mathrm{a}$ & $\mathrm{n} / \mathrm{a}$ & $\mathrm{n} / \mathrm{a}$ & $\mathrm{n} / \mathrm{a}$ & 12.5 & \\
\hline S11T011049 & Cerium & $\mathrm{ug} / \mathrm{mL}$ & 101 & $n / a$ & $<75.0$ & $\mathrm{n} / \mathrm{a}$ & $\mathrm{n} / \mathrm{a}$ & $\mathrm{n} / \mathrm{a}$ & $\mathrm{n} / \mathrm{a}$ & 75.0 & \\
\hline S11T011049 & Cobalt & $\mathrm{ug} / \mathrm{mL}$ & 101 & $\mathrm{n} / \mathrm{a}$ & $<25.0$ & $\mathrm{n} / \mathrm{a}$ & $\mathrm{n} / \mathrm{a}$ & $\mathrm{n} / \mathrm{a}$ & $\mathrm{n} / \mathrm{a}$ & 25.0 & \\
\hline S11T011049 & Chromium & $\mathrm{ug} / \mathrm{mL}$ & 101 & $<5.00 \mathrm{E}-03$ & 553 & 588 & 571 & 6.15 & 95.9 & 12.5 & \\
\hline S11T011049 & Copper & $\mathrm{ug} / \mathrm{mL}$ & 102 & $\mathrm{n} / \mathrm{a}$ & $<12.5$ & $\mathrm{n} / \mathrm{a}$ & $\mathrm{n} / \mathrm{a}$ & $\mathrm{n} / \mathrm{a}$ & $\mathrm{n} / \mathrm{a}$ & 12.5 & \\
\hline S11T011049 & Europium & $\mathrm{ug} / \mathrm{mL}$ & 95.4 & $\mathrm{n} / \mathrm{a}$ & $<12.5$ & $\mathrm{n} / \mathrm{a}$ & $\mathrm{n} / \mathrm{a}$ & $\mathrm{n} / \mathrm{a}$ & $\mathrm{n} / \mathrm{a}$ & 12.5 & \\
\hline
\end{tabular}


Table D-1. Tank 241-AP-107 Boildown Composite (Sample CON 0). (2 sheets) Sampl(s): S11T011048 and S11T011049 (Test Samples CON 0A and CON 0B)

Sample Group: 20111225

\begin{tabular}{|c|c|c|c|c|c|c|c|c|c|c|c|}
\hline Sample \# & Analyte & Unit & $\begin{array}{c}\text { Std } \\
\%-\operatorname{Rec}\end{array}$ & Blank & Result & Duplicate & Average & RPD & $\begin{array}{c}\text { Spk } \\
\% \text {-Rec }\end{array}$ & $\begin{array}{c}\text { Det } \\
\text { Limit }\end{array}$ & $\begin{array}{l}\text { Qual } \\
\text { Flags }\end{array}$ \\
\hline S11T011049 & Iron & $\mathrm{ug} / \mathrm{mL}$ & 101 & $\mathrm{n} / \mathrm{a}$ & $<12.5$ & $\mathrm{n} / \mathrm{a}$ & $\mathrm{n} / \mathrm{a}$ & $\mathrm{n} / \mathrm{a}$ & $\mathrm{n} / \mathrm{a}$ & 12.5 & \\
\hline S11T011049 & Potassium & $\mathrm{ug} / \mathrm{mL}$ & 92.3 & $<0.500$ & $<1.25 \mathrm{E}+03$ & $1.45 \mathrm{E}+03$ & $1.35 \mathrm{E}+03$ & 14.6 & 89.4 & $1.25 \mathrm{E}+03$ & $\mathrm{U}$ \\
\hline S11T011049 & Lanthanum & $\mathrm{ug} / \mathrm{mL}$ & 99.5 & $\mathrm{n} / \mathrm{a}$ & $<7.50$ & $\mathrm{n} / \mathrm{a}$ & $\mathrm{n} / \mathrm{a}$ & $\mathrm{n} / \mathrm{a}$ & $\mathrm{n} / \mathrm{a}$ & 7.50 & \\
\hline S11T011049 & Lithium & $\mathrm{ug} / \mathrm{mL}$ & 109 & $\mathrm{n} / \mathrm{a}$ & $<7.50$ & $\mathrm{n} / \mathrm{a}$ & $\mathrm{n} / \mathrm{a}$ & $\mathrm{n} / \mathrm{a}$ & $\mathrm{n} / \mathrm{a}$ & 7.50 & \\
\hline S11T011049 & Magnesium & $\mathrm{ug} / \mathrm{mL}$ & 102 & $\mathrm{n} / \mathrm{a}$ & $<125$ & $\mathrm{n} / \mathrm{a}$ & $\mathrm{n} / \mathrm{a}$ & $\mathrm{n} / \mathrm{a}$ & $\mathrm{n} / \mathrm{a}$ & 125 & \\
\hline S11T011049 & Manganese & $\mathrm{ug} / \mathrm{mL}$ & 100 & $\mathrm{n} / \mathrm{a}$ & $<7.50$ & $\mathrm{n} / \mathrm{a}$ & $\mathrm{n} / \mathrm{a}$ & $\mathrm{n} / \mathrm{a}$ & $\mathrm{n} / \mathrm{a}$ & 7.50 & \\
\hline S11T011049 & Molybdenum & $\mathrm{ug} / \mathrm{mL}$ & 98.8 & $\mathrm{n} / \mathrm{a}$ & $<50.0$ & $\mathrm{n} / \mathrm{a}$ & $\mathrm{n} / \mathrm{a}$ & $\mathrm{n} / \mathrm{a}$ & $\mathrm{n} / \mathrm{a}$ & 50.0 & \\
\hline S11T011049 & Sodium & $\mathrm{ug} / \mathrm{mL}$ & 106 & $<0.100$ & $1.07 \mathrm{E}+05$ & $1.07 \mathrm{E}+05$ & $1.07 \mathrm{E}+05$ & 0.684 & 88.9 & 250 & \\
\hline S11T011049 & Neodymium & $\mathrm{ug} / \mathrm{mL}$ & 100 & $\mathrm{n} / \mathrm{a}$ & $<25.0$ & $\mathrm{n} / \mathrm{a}$ & $\mathrm{n} / \mathrm{a}$ & $\mathrm{n} / \mathrm{a}$ & $\mathrm{n} / \mathrm{a}$ & 25.0 & \\
\hline S11T011049 & Nickel & $\mathrm{ug} / \mathrm{mL}$ & 101 & $\mathrm{n} / \mathrm{a}$ & $<50.0$ & $\mathrm{n} / \mathrm{a}$ & $\mathrm{n} / \mathrm{a}$ & $\mathrm{n} / \mathrm{a}$ & $\mathrm{n} / \mathrm{a}$ & 50.0 & \\
\hline S11T011049 & Phosphorus & $\mathrm{ug} / \mathrm{mL}$ & 102 & $<0.0500$ & 973 & 884 & 929 & 9.68 & 96.3 & 125 & $\mathrm{~J}$ \\
\hline S11T011049 & Lead & $\mathrm{ug} / \mathrm{mL}$ & 104 & $\mathrm{n} / \mathrm{a}$ & $<125$ & $\mathrm{n} / \mathrm{a}$ & $\mathrm{n} / \mathrm{a}$ & $\mathrm{n} / \mathrm{a}$ & $\mathrm{n} / \mathrm{a}$ & 125 & \\
\hline S11T011049 & Sulfur & $\mathrm{ug} / \mathrm{mL}$ & 98.4 & $<0.100$ & $3.08 \mathrm{E}+03$ & $3.13 \mathrm{E}+03$ & $3.10 \mathrm{E}+03$ & 1.38 & 98.5 & 250 & \\
\hline S11T011049 & Antimony & $\mathrm{ug} / \mathrm{mL}$ & 94.6 & $\mathrm{n} / \mathrm{a}$ & $<125$ & $\mathrm{n} / \mathrm{a}$ & $\mathrm{n} / \mathrm{a}$ & $\mathrm{n} / \mathrm{a}$ & $\mathrm{n} / \mathrm{a}$ & 125 & \\
\hline S11T011049 & Selenium & $\mathrm{ug} / \mathrm{mL}$ & 104 & $\mathrm{n} / \mathrm{a}$ & $<250$ & $\mathrm{n} / \mathrm{a}$ & $\mathrm{n} / \mathrm{a}$ & $\mathrm{n} / \mathrm{a}$ & $\mathrm{n} / \mathrm{a}$ & 250 & \\
\hline S11T011049 & Silicon & $\mathrm{ug} / \mathrm{mL}$ & 94.7 & $<0.0300$ & 92.3 & 125 & 108 & 29.7 & 93.3 & 75.0 & $\mathrm{~J}$ \\
\hline S11T011049 & Samarium & $\mathrm{ug} / \mathrm{mL}$ & 103 & $\mathrm{n} / \mathrm{a}$ & $<125$ & $\mathrm{n} / \mathrm{a}$ & $\mathrm{n} / \mathrm{a}$ & $\mathrm{n} / \mathrm{a}$ & $\mathrm{n} / \mathrm{a}$ & 125 & \\
\hline S11T011049 & Strontium & $\mathrm{ug} / \mathrm{mL}$ & 101 & $\mathrm{n} / \mathrm{a}$ & $<7.50$ & $\mathrm{n} / \mathrm{a}$ & $\mathrm{n} / \mathrm{a}$ & $\mathrm{n} / \mathrm{a}$ & $\mathrm{n} / \mathrm{a}$ & 7.50 & \\
\hline S11T011049 & Thorium & $\mathrm{ug} / \mathrm{mL}$ & 97.5 & $\mathrm{n} / \mathrm{a}$ & $<125$ & $\mathrm{n} / \mathrm{a}$ & $\mathrm{n} / \mathrm{a}$ & $\mathrm{n} / \mathrm{a}$ & $\mathrm{n} / \mathrm{a}$ & 125 & \\
\hline S11T011049 & Titanium & $\mathrm{ug} / \mathrm{mL}$ & 97.3 & $\mathrm{n} / \mathrm{a}$ & $<12.5$ & $\mathrm{n} / \mathrm{a}$ & $\mathrm{n} / \mathrm{a}$ & $\mathrm{n} / \mathrm{a}$ & $\mathrm{n} / \mathrm{a}$ & 12.5 & \\
\hline S11T011049 & Thallium & $\mathrm{ug} / \mathrm{mL}$ & 96.2 & $\mathrm{n} / \mathrm{a}$ & $<250$ & $\mathrm{n} / \mathrm{a}$ & $\mathrm{n} / \mathrm{a}$ & $\mathrm{n} / \mathrm{a}$ & $\mathrm{n} / \mathrm{a}$ & 250 & \\
\hline S11T011049 & Uranium & $\mathrm{ug} / \mathrm{mL}$ & 101 & $\mathrm{n} / \mathrm{a}$ & $<250$ & $\mathrm{n} / \mathrm{a}$ & $\mathrm{n} / \mathrm{a}$ & $\mathrm{n} / \mathrm{a}$ & $\mathrm{n} / \mathrm{a}$ & 250 & \\
\hline S11T011049 & Vanadium & $\mathrm{ug} / \mathrm{mL}$ & 101 & $\mathrm{n} / \mathrm{a}$ & $<12.5$ & $\mathrm{n} / \mathrm{a}$ & $\mathrm{n} / \mathrm{a}$ & $\mathrm{n} / \mathrm{a}$ & $\mathrm{n} / \mathrm{a}$ & 12.5 & \\
\hline S11T011049 & Yttrium & $\mathrm{ug} / \mathrm{mL}$ & 94.7 & $\mathrm{n} / \mathrm{a}$ & $<5.00$ & $\mathrm{n} / \mathrm{a}$ & $\mathrm{n} / \mathrm{a}$ & $\mathrm{n} / \mathrm{a}$ & $\mathrm{n} / \mathrm{a}$ & 5.00 & \\
\hline S11T011049 & Zinc & $\mathrm{ug} / \mathrm{mL}$ & 99.9 & $\mathrm{n} / \mathrm{a}$ & $<12.5$ & $\mathrm{n} / \mathrm{a}$ & $\mathrm{n} / \mathrm{a}$ & $\mathrm{n} / \mathrm{a}$ & $\mathrm{n} / \mathrm{a}$ & 12.5 & \\
\hline S11T011049 & Zirconium & $\mathrm{ug} / \mathrm{mL}$ & 98.9 & $\mathrm{n} / \mathrm{a}$ & $<12.5$ & $\mathrm{n} / \mathrm{a}$ & $\mathrm{n} / \mathrm{a}$ & $\mathrm{n} / \mathrm{a}$ & $\mathrm{n} / \mathrm{a}$ & 12.5 & \\
\hline S11T011049 & Hydroxide & $\mathrm{ug} / \mathrm{mL}$ & 105 & $<41.7$ & $1.0 \mathrm{E}+04$ & $1.03 \mathrm{E}+04$ & $1.0 \mathrm{E}+04$ & 2.09 & 103 & 550 & \\
\hline S11T011049 & Specific gravity & unitless & 100.5 & $\mathrm{n} / \mathrm{a}$ & 1.225 & 1.261 & 1.243 & 2.896 & $\mathrm{n} / \mathrm{a}$ & $1.00 \mathrm{E}-03$ & \\
\hline
\end{tabular}


Table D-2. Centrifuged Liquid from Sample CON 1. (2 sheets)

Sample(s): S11T011062 (Test Sample CON 1)

Sample Group: 20111225

\begin{tabular}{|c|c|c|c|c|c|c|c|c|c|c|c|}
\hline Sample \# & Analyte & Unit & $\begin{array}{c}\text { Std } \\
\%-\operatorname{Rec}\end{array}$ & Blank & Result & Duplicate & Average & RPD & $\begin{array}{c}\text { Spk } \\
\% \text {-Rec }\end{array}$ & $\begin{array}{c}\text { Det } \\
\text { Limit }\end{array}$ & $\begin{array}{l}\text { Qual } \\
\text { Flags }\end{array}$ \\
\hline S11T011062 & Fluoride & $\mathrm{ug} / \mathrm{mL}$ & 103 & $<1.61 \mathrm{E}-03$ & 533 & $\mathrm{n} / \mathrm{a}$ & $\mathrm{n} / \mathrm{a}$ & $\mathrm{n} / \mathrm{a}$ & $\mathrm{n} / \mathrm{a}$ & 1.61 & \\
\hline S11T011062 & \begin{tabular}{|l|} 
Glycolate \\
\end{tabular} & $\mathrm{ug} / \mathrm{mL}$ & 101 & $<9.37 \mathrm{E}-03$ & 253 & $\mathrm{n} / \mathrm{a}$ & $\mathrm{n} / \mathrm{a}$ & $\mathrm{n} / \mathrm{a}$ & $\mathrm{n} / \mathrm{a}$ & 9.37 & \\
\hline S11T011062 & Acetate & $\mathrm{ug} / \mathrm{mL}$ & 101 & $<6.04 \mathrm{E}-03$ & 289 & $\mathrm{n} / \mathrm{a}$ & $\mathrm{n} / \mathrm{a}$ & $\mathrm{n} / \mathrm{a}$ & $\mathrm{n} / \mathrm{a}$ & 6.04 & \\
\hline S11T011062 & \begin{tabular}{|l|} 
Formate \\
\end{tabular} & $\mathrm{ug} / \mathrm{mL}$ & 101 & $<<.67 \mathrm{E}-03$ & \begin{tabular}{|l|}
889 \\
\end{tabular} & $\mathrm{n} / \mathrm{a}$ & $\mathrm{n} / \mathrm{a}$ & $\mathrm{n} / \mathrm{a}$ & $\mathrm{n} / \mathrm{a}$ & 4.67 & \\
\hline S11T011062 & Chloride & $\mathrm{ug} / \mathrm{mL}$ & 101 & 0.0131 & $1.92 \mathrm{E}+03$ & $\mathrm{n} / \mathrm{a}$ & $\mathrm{n} / \mathrm{a}$ & $\mathrm{n} / \mathrm{a}$ & $\mathrm{n} / \mathrm{a}$ & 9.98 & \\
\hline S11T011062 & Nitrite & $\mathrm{ug} / \mathrm{mL}$ & 100 & $<0.0192$ & $4.15 \mathrm{E}+04$ & $\mathrm{n} / \mathrm{a}$ & $\mathrm{n} / \mathrm{a}$ & $n / a$ & $\mathrm{n} / \mathrm{a}$ & 96.0 & \\
\hline S11T011062 & Sulfate & $\mathrm{ug} / \mathrm{mL}$ & 102 & $<0.0187$ & $1.25 \mathrm{E}+04$ & $\mathrm{n} / \mathrm{a}$ & $\mathrm{n} / \mathrm{a}$ & $\mathrm{n} / \mathrm{a}$ & $\mathrm{n} / \mathrm{a}$ & 18.7 & \\
\hline S11T011062 & Oxalate & $\mathrm{ug} / \mathrm{mL}$ & 102 & $<0.0231$ & 699 & n/a & $\mathrm{n} / \mathrm{a}$ & $\mathrm{n} / \mathrm{a}$ & $\mathrm{n} / \mathrm{a}$ & 23.1 & \\
\hline S11T011062 & \begin{tabular}{|l|} 
Bromide \\
\end{tabular} & $\mathrm{ug} / \mathrm{mL}$ & 101 & $<0.0580$ & $<58.0$ & $\mathrm{n} / \mathrm{a}$ & $\mathrm{n} / \mathrm{a}$ & $\mathrm{n} / \mathrm{a}$ & $\mathrm{n} / \mathrm{a}$ & 58.0 & $\mathrm{U}$ \\
\hline S11T011062 & Nitrate & $\mathrm{ug} / \mathrm{mL}$ & 101 & 0.0680 & $1.62 \mathrm{E}+05$ & $\mathrm{n} / \mathrm{a}$ & $\mathrm{n} / \mathrm{a}$ & $\mathrm{n} / \mathrm{a}$ & $\mathrm{n} / \mathrm{a}$ & 208 & \\
\hline S11T011062 & Phosphate & $\mathrm{ug} / \mathrm{mL}$ & 101 & $<0.0167$ & $2.91 \mathrm{E}+03$ & $\mathrm{n} / \mathrm{a}$ & $\mathrm{n} / \mathrm{a}$ & $\mathrm{n} / \mathrm{a}$ & $\mathrm{n} / \mathrm{a}$ & 16.7 & \\
\hline S11T011062 & Silver & $\mathrm{ug} / \mathrm{mL}$ & 98.6 & $\mathrm{n} / \mathrm{a}$ & $<12.5$ & $\mathrm{n} / \mathrm{a}$ & $\mathrm{n} / \mathrm{a}$ & $\mathrm{n} / \mathrm{a}$ & $\mathrm{n} / \mathrm{a}$ & 12.5 & \\
\hline S11T011062 & Aluminum & $\mathrm{ug} / \mathrm{mL}$ & 101 & $<0.0300$ & $6.29 \mathrm{E}+03$ & $\mathrm{n} / \mathrm{a}$ & $\mathrm{n} / \mathrm{a}$ & $\mathrm{n} / \mathrm{a}$ & $\mathrm{n} / \mathrm{a}$ & 75.0 & \\
\hline S11T011062 & Arsenic & $\mathrm{ug} / \mathrm{mL}$ & 100 & $\mathrm{n} / \mathrm{a}$ & $<125$ & $\mathrm{n} / \mathrm{a}$ & $\mathrm{n} / \mathrm{a}$ & $\mathrm{n} / \mathrm{a}$ & $\mathrm{n} / \mathrm{a}$ & 125 & \\
\hline S11T011062 & Boron & $\mathrm{ug} / \mathrm{mL}$ & 99.3 & $\mathrm{n} / \mathrm{a}$ & $<75.0$ & $\mathrm{n} / \mathrm{a}$ & $\mathrm{n} / \mathrm{a}$ & $\mathrm{n} / \mathrm{a}$ & $\mathrm{n} / \mathrm{a}$ & 75.0 & \\
\hline S11T011062 & Barium & $\mathrm{ug} / \mathrm{mL}$ & 101 & $\mathrm{n} / \mathrm{a}$ & $<7.50$ & $\mathrm{n} / \mathrm{a}$ & $\mathrm{n} / \mathrm{a}$ & $\mathrm{n} / \mathrm{a}$ & $\mathrm{n} / \mathrm{a}$ & 7.50 & \\
\hline S11T011062 & Beryllium & $\mathrm{ug} / \mathrm{mL}$ & 98.9 & $\mathrm{n} / \mathrm{a}$ & $<2.50$ & $\mathrm{n} / \mathrm{a}$ & $\mathrm{n} / \mathrm{a}$ & $\mathrm{n} / \mathrm{a}$ & $\mathrm{n} / \mathrm{a}$ & 2.50 & \\
\hline S11T011062 & Bismuth & $\mathrm{ug} / \mathrm{mL}$ & 100 & $\mathrm{n} / \mathrm{a}$ & $<250$ & $\mathrm{n} / \mathrm{a}$ & $\mathrm{n} / \mathrm{a}$ & $\mathrm{n} / \mathrm{a}$ & $\mathrm{n} / \mathrm{a}$ & 250 & \\
\hline S11T011062 & Calcium & $\mathrm{ug} / \mathrm{mL}$ & 101 & $<0.0500$ & $<125$ & n/a & $\mathrm{n} / \mathrm{a}$ & $\mathrm{n} / \mathrm{a}$ & $\mathrm{n} / \mathrm{a}$ & 125 & U \\
\hline S11T011062 & Cadmium & $\mathrm{ug} / \mathrm{mL}$ & 102 & $\mathrm{n} / \mathrm{a}$ & $<12.5$ & $\mathrm{n} / \mathrm{a}$ & $\mathrm{n} / \mathrm{a}$ & $\mathrm{n} / \mathrm{a}$ & $\mathrm{n} / \mathrm{a}$ & 12.5 & \\
\hline S11T011062 & Cerium & $\mathrm{ug} / \mathrm{mL}$ & 101 & $\mathrm{n} / \mathrm{a}$ & $<75.0$ & $\mathrm{n} / \mathrm{a}$ & $\mathrm{n} / \mathrm{a}$ & $\mathrm{n} / \mathrm{a}$ & $\mathrm{n} / \mathrm{a}$ & 75.0 & \\
\hline S11T011062 & Cobalt & $\mathrm{ug} / \mathrm{mL}$ & 101 & $\mathrm{n} / \mathrm{a}$ & $<25.0$ & $\mathrm{n} / \mathrm{a}$ & $\mathrm{n} / \mathrm{a}$ & $\mathrm{n} / \mathrm{a}$ & $\mathrm{n} / \mathrm{a}$ & 25.0 & \\
\hline S11T011062 & Chromium & $\mathrm{ug} / \mathrm{mL}$ & 101 & $<5.00 \mathrm{E}-03$ & 833 & $\mathrm{n} / \mathrm{a}$ & $\mathrm{n} / \mathrm{a}$ & $\mathrm{n} / \mathrm{a}$ & $\mathrm{n} / \mathrm{a}$ & 12.5 & \\
\hline S11T011062 & \begin{tabular}{|l|} 
Copper \\
\end{tabular} & $\mathrm{ug} / \mathrm{mL}$ & 102 & $\mathrm{n} / \mathrm{a}$ & $<12.5$ & $\mathrm{n} / \mathrm{a}$ & $\mathrm{n} / \mathrm{a}$ & $\mathrm{n} / \mathrm{a}$ & $\mathrm{n} / \mathrm{a}$ & 12.5 & \\
\hline S11T011062 & Europium & $\mathrm{ug} / \mathrm{mL}$ & 95.4 & $\mathrm{n} / \mathrm{a}$ & $<12.5$ & $\mathrm{n} / \mathrm{a}$ & $\mathrm{n} / \mathrm{a}$ & $\mathrm{n} / \mathrm{a}$ & $\mathrm{n} / \mathrm{a}$ & 12.5 & \\
\hline S11T011062 & Iron & $\mathrm{ug} / \mathrm{mL}$ & 101 & $\mathrm{n} / \mathrm{a}$ & $<12.5$ & n/a & $\mathrm{n} / \mathrm{a}$ & $\mathrm{n} / \mathrm{a}$ & $\mathrm{n} / \mathrm{a}$ & 12.5 & \\
\hline S11T011062 & Potassium & $\mathrm{ug} / \mathrm{mL}$ & 92.3 & $<0.500$ & $2.17 \mathrm{E}+03$ & $\mathrm{n} / \mathrm{a}$ & $\mathrm{n} / \mathrm{a}$ & $\mathrm{n} / \mathrm{a}$ & $\mathrm{n} / \mathrm{a}$ & $1.25 \mathrm{E}+03$ & $\mathrm{~J}$ \\
\hline S11T011062 & Lanthanum & $\mathrm{ug} / \mathrm{mL}$ & 99.5 & $\mathrm{n} / \mathrm{a}$ & $<7.50$ & $\mathrm{n} / \mathrm{a}$ & $\mathrm{n} / \mathrm{a}$ & $\mathrm{n} / \mathrm{a}$ & $\mathrm{n} / \mathrm{a}$ & 7.50 & \\
\hline
\end{tabular}


Table D-2. Centrifuged Liquid from Sample CON 1. (2 sheets)

Sample Number(s): S11T011062 (Test Sample CON 1)

Sample Group: 20111225

\begin{tabular}{|c|c|c|c|c|c|c|c|c|c|c|c|}
\hline Sample \# & Analyte & Unit & $\begin{array}{c}\text { Std } \\
\%-\operatorname{Rec}\end{array}$ & Blank & Result & Duplicate & Average & RPD & $\begin{array}{c}\text { Spk } \\
\% \text {-Rec }\end{array}$ & $\begin{array}{c}\text { Det } \\
\text { Limit }\end{array}$ & $\begin{array}{l}\text { Qual } \\
\text { Flags }\end{array}$ \\
\hline S11T011062 & Lithium & $\mathrm{ug} / \mathrm{mL}$ & \begin{tabular}{|l|}
109 \\
\end{tabular} & $\mathrm{n} / \mathrm{a}$ & $<7.50$ & $\mathrm{n} / \mathrm{a}$ & $\mathrm{n} / \mathrm{a}$ & $\mathrm{n} / \mathrm{a}$ & $\mathrm{n} / \mathrm{a}$ & 7.50 & \\
\hline S11T011062 & Magnesium & $\mathrm{ug} / \mathrm{mL}$ & 102 & $\mathrm{n} / \mathrm{a}$ & $<125$ & $\mathrm{n} / \mathrm{a}$ & $\mathrm{n} / \mathrm{a}$ & $\mathrm{n} / \mathrm{a}$ & $\mathrm{n} / \mathrm{a}$ & 125 & \\
\hline S11T011062 & Manganese & $\mathrm{ug} / \mathrm{mL}$ & 100 & $\mathrm{n} / \mathrm{a}$ & $<7.50$ & $\mathrm{n} / \mathrm{a}$ & $\mathrm{n} / \mathrm{a}$ & $\mathrm{n} / \mathrm{a}$ & $\mathrm{n} / \mathrm{a}$ & 7.50 & \\
\hline S11T011062 & Molybdenum & $\mathrm{ug} / \mathrm{mL}$ & 98.8 & $\mathrm{n} / \mathrm{a}$ & 61.6 & $\mathrm{n} / \mathrm{a}$ & $\mathrm{n} / \mathrm{a}$ & $\mathrm{n} / \mathrm{a}$ & $\mathrm{n} / \mathrm{a}$ & 50.0 & \\
\hline S11T011062 & Sodium & $\mathrm{ug} / \mathrm{mL}$ & 106 & $<0.100$ & $1.44 \mathrm{E}+05$ & $\mathrm{n} / \mathrm{a}$ & $\mathrm{n} / \mathrm{a}$ & $\mathrm{n} / \mathrm{a}$ & $\mathrm{n} / \mathrm{a}$ & 250 & \\
\hline S11T011062 & Neodymium & $\mathrm{ug} / \mathrm{mL}$ & 100 & $\mathrm{n} / \mathrm{a}$ & $<25.0$ & $\mathrm{n} / \mathrm{a}$ & $\mathrm{n} / \mathrm{a}$ & $\mathrm{n} / \mathrm{a}$ & $\mathrm{n} / \mathrm{a}$ & 25.0 & \\
\hline S11T011062 & Nickel & $\mathrm{ug} / \mathrm{mL}$ & 101 & $\mathrm{n} / \mathrm{a}$ & $<50.0$ & $\mathrm{n} / \mathrm{a}$ & $\mathrm{n} / \mathrm{a}$ & $\mathrm{n} / \mathrm{a}$ & $\mathrm{n} / \mathrm{a}$ & 50.0 & \\
\hline S11T011062 & Phosphorus & $\mathrm{ug} / \mathrm{mL}$ & 102 & $<0.0500$ & 939 & $\mathrm{n} / \mathrm{a}$ & $\mathrm{n} / \mathrm{a}$ & $\mathrm{n} / \mathrm{a}$ & $\mathrm{n} / \mathrm{a}$ & 125 & $\mathrm{~J}$ \\
\hline S11T011062 & Lead & $\mathrm{ug} / \mathrm{mL}$ & 104 & $\mathrm{n} / \mathrm{a}$ & $<125$ & $\mathrm{n} / \mathrm{a}$ & $\mathrm{n} / \mathrm{a}$ & $\mathrm{n} / \mathrm{a}$ & $\mathrm{n} / \mathrm{a}$ & 125 & \\
\hline S11T011062 & Sulfur & $\mathrm{ug} / \mathrm{mL}$ & 98.4 & $<0.100$ & $4.37 \mathrm{E}+03$ & $\mathrm{n} / \mathrm{a}$ & $\mathrm{n} / \mathrm{a}$ & $\mathrm{n} / \mathrm{a}$ & $\mathrm{n} / \mathrm{a}$ & 250 & \\
\hline S11T011062 & Antimony & $\mathrm{ug} / \mathrm{mL}$ & 94.6 & $\mathrm{n} / \mathrm{a}$ & $<125$ & $\mathrm{n} / \mathrm{a}$ & $\mathrm{n} / \mathrm{a}$ & $\mathrm{n} / \mathrm{a}$ & $\mathrm{n} / \mathrm{a}$ & 125 & \\
\hline S11T011062 & Selenium & $\mathrm{ug} / \mathrm{mL}$ & 104 & $\mathrm{n} / \mathrm{a}$ & $<250$ & $\mathrm{n} / \mathrm{a}$ & $\mathrm{n} / \mathrm{a}$ & $\mathrm{n} / \mathrm{a}$ & $\mathrm{n} / \mathrm{a}$ & 250 & \\
\hline S11T011062 & \begin{tabular}{|l|} 
Silicon \\
\end{tabular} & $\mathrm{ug} / \mathrm{mL}$ & 94.7 & $<0.0300$ & 355 & $\mathrm{n} / \mathrm{a}$ & $\mathrm{n} / \mathrm{a}$ & $\mathrm{n} / \mathrm{a}$ & $\mathrm{n} / \mathrm{a}$ & 75.0 & $\mathrm{~J}$ \\
\hline S11T011062 & Samarium & $\mathrm{ug} / \mathrm{mL}$ & 103 & $\mathrm{n} / \mathrm{a}$ & $<125$ & $\mathrm{n} / \mathrm{a}$ & $\mathrm{n} / \mathrm{a}$ & $\mathrm{n} / \mathrm{a}$ & $\mathrm{n} / \mathrm{a}$ & 125 & \\
\hline S11T011062 & Strontium & $\mathrm{ug} / \mathrm{mL}$ & 101 & $\mathrm{n} / \mathrm{a}$ & $<7.50$ & $\mathrm{n} / \mathrm{a}$ & n/a & $\mathrm{n} / \mathrm{a}$ & $\mathrm{n} / \mathrm{a}$ & 7.50 & \\
\hline S11T011062 & Thorium & $\mathrm{ug} / \mathrm{mL}$ & 97.5 & $\mathrm{n} / \mathrm{a}$ & $<125$ & $\mathrm{n} / \mathrm{a}$ & n/a & $\mathrm{n} / \mathrm{a}$ & $\mathrm{n} / \mathrm{a}$ & 125 & \\
\hline S11T011062 & \begin{tabular}{|l|} 
Titanium \\
\end{tabular} & $\mathrm{ug} / \mathrm{mL}$ & 97.3 & $\mathrm{n} / \mathrm{a}$ & $<12.5$ & $\mathrm{n} / \mathrm{a}$ & $\mathrm{n} / \mathrm{a}$ & $\mathrm{n} / \mathrm{a}$ & $\mathrm{n} / \mathrm{a}$ & 12.5 & \\
\hline S11T011062 & Thallium & $\mathrm{ug} / \mathrm{mL}$ & 96.2 & $\mathrm{n} / \mathrm{a}$ & $<250$ & $\mathrm{n} / \mathrm{a}$ & $\mathrm{n} / \mathrm{a}$ & $\mathrm{n} / \mathrm{a}$ & $\mathrm{n} / \mathrm{a}$ & 250 & \\
\hline S11T011062 & Uranium & $\mathrm{ug} / \mathrm{mL}$ & 101 & $\mathrm{n} / \mathrm{a}$ & $<250$ & $\mathrm{n} / \mathrm{a}$ & $\mathrm{n} / \mathrm{a}$ & $\mathrm{n} / \mathrm{a}$ & $\mathrm{n} / \mathrm{a}$ & 250 & \\
\hline S11T011062 & Vanadium & $\mathrm{ug} / \mathrm{mL}$ & 101 & $\mathrm{n} / \mathrm{a}$ & $<12.5$ & $\mathrm{n} / \mathrm{a}$ & $\mathrm{n} / \mathrm{a}$ & $\mathrm{n} / \mathrm{a}$ & $\mathrm{n} / \mathrm{a}$ & 12.5 & \\
\hline S11T011062 & Yttrium & $\mathrm{ug} / \mathrm{mL}$ & 94.7 & $\mathrm{n} / \mathrm{a}$ & $<5.00$ & $\mathrm{n} / \mathrm{a}$ & $\mathrm{n} / \mathrm{a}$ & $\mathrm{n} / \mathrm{a}$ & $\mathrm{n} / \mathrm{a}$ & 5.00 & \\
\hline S11T011062 & Zinc & $\mathrm{ug} / \mathrm{mL}$ & 99.9 & $\mathrm{n} / \mathrm{a}$ & $<12.5$ & $\mathrm{n} / \mathrm{a}$ & $\mathrm{n} / \mathrm{a}$ & $\mathrm{n} / \mathrm{a}$ & $\mathrm{n} / \mathrm{a}$ & 12.5 & \\
\hline S11T011062 & Zirconium & $\mathrm{ug} / \mathrm{mL}$ & 98.9 & $\mathrm{n} / \mathrm{a}$ & $<12.5$ & $\mathrm{n} / \mathrm{a}$ & $\mathrm{n} / \mathrm{a}$ & $\mathrm{n} / \mathrm{a}$ & $\mathrm{n} / \mathrm{a}$ & 12.5 & \\
\hline S11T011062 & Hydroxide & $\mathrm{ug} / \mathrm{mL}$ & 105 & $<41.7$ & $1.4 \mathrm{E}+04$ & $\mathrm{n} / \mathrm{a}$ & $\mathrm{n} / \mathrm{a}$ & $\mathrm{n} / \mathrm{a}$ & $\mathrm{n} / \mathrm{a}$ & 550 & \\
\hline S11T011062 & Specific gravity & unitless & 100.5 & $\mathrm{n} / \mathrm{a}$ & 1.319 & $\mathrm{n} / \mathrm{a}$ & $\mathrm{n} / \mathrm{a}$ & $\mathrm{n} / \mathrm{a}$ & $\mathrm{n} / \mathrm{a}$ & $1.00 \mathrm{E}-03$ & \\
\hline $\mathrm{S} 11 \mathrm{~T} 011062$ & Total organic carbon & $\mathrm{ug} / \mathrm{mL}$ & 97.9 & $<20.0$ & 982 & $\mathrm{n} / \mathrm{a}$ & $\mathrm{n} / \mathrm{a}$ & $\mathrm{n} / \mathrm{a}$ & $\mathrm{n} / \mathrm{a}$ & 100 & $\mathrm{~J}$ \\
\hline S11T011062 & Total inorganic carbon & $\mathrm{ug} / \mathrm{mL}$ & 80.0 & $<7.00$ & $7.35 \mathrm{E}+03$ & $\mathrm{n} / \mathrm{a}$ & $\mathrm{n} / \mathrm{a}$ & $\mathrm{n} / \mathrm{a}$ & $\mathrm{n} / \mathrm{a}$ & 35.0 & \\
\hline
\end{tabular}


Table D-3. Centrifuged Liquid from Sample CON 2. (2 sheets)

Sample Number(s): S11T011063 (Test Sample CON 2)

Sample Group: 20111225

\begin{tabular}{|c|c|c|c|c|c|c|c|c|c|c|c|}
\hline Sample \# & Analyte & Unit & $\begin{array}{c}\text { Std } \\
\%-\operatorname{Rec}\end{array}$ & Blank & Result & Duplicate & Average & RPD & $\begin{array}{c}\text { Spk } \\
\text { \%-Rec }\end{array}$ & $\begin{array}{c}\text { Det } \\
\text { Limit }\end{array}$ & $\begin{array}{l}\text { Qual } \\
\text { Flags }\end{array}$ \\
\hline S11T011063 & Fluoride & $\mathrm{ug} / \mathrm{mL}$ & 103 & $<1.61 \mathrm{E}-03$ & 488 & $\mathrm{n} / \mathrm{a}$ & $\mathrm{n} / \mathrm{a}$ & $\mathrm{n} / \mathrm{a}$ & $\mathrm{n} / \mathrm{a}$ & 1.61 & \\
\hline S11T011063 & Glycolate & $\mathrm{ug} / \mathrm{mL}$ & 101 & $<9.37 \mathrm{E}-03$ & 273 & $\mathrm{n} / \mathrm{a}$ & $\mathrm{n} / \mathrm{a}$ & $\mathrm{n} / \mathrm{a}$ & $\mathrm{n} / \mathrm{a}$ & 9.37 & \\
\hline S11T011063 & Acetate & $\mathrm{ug} / \mathrm{mL}$ & 101 & $<6.04 \mathrm{E}-03$ & 296 & $\mathrm{n} / \mathrm{a}$ & $\mathrm{n} / \mathrm{a}$ & $\mathrm{n} / \mathrm{a}$ & $\mathrm{n} / \mathrm{a}$ & 6.04 & \\
\hline S11T011063 & Formate & $\mathrm{ug} / \mathrm{mL}$ & 101 & $<4.67 \mathrm{E}-03$ & 994 & $\mathrm{n} / \mathrm{a}$ & $\mathrm{n} / \mathrm{a}$ & $\mathrm{n} / \mathrm{a}$ & $\mathrm{n} / \mathrm{a}$ & 4.67 & \\
\hline S11T011063 & Chloride & $\mathrm{ug} / \mathrm{mL}$ & 101 & 0.0131 & $2.18 \mathrm{E}+03$ & $\mathrm{n} / \mathrm{a}$ & $\mathrm{n} / \mathrm{a}$ & $\mathrm{n} / \mathrm{a}$ & $\mathrm{n} / \mathrm{a}$ & 9.98 & \\
\hline S11T011063 & Nitrite & $\mathrm{ug} / \mathrm{mL}$ & 101 & $<0.0192$ & $4.72 \mathrm{E}+04$ & $n / a$ & $\mathrm{n} / \mathrm{a}$ & $\mathrm{n} / \mathrm{a}$ & $\mathrm{n} / \mathrm{a}$ & 96.0 & \\
\hline S11T011063 & Sulfate & $\mathrm{ug} / \mathrm{mL}$ & 102 & $<0.0187$ & $1.40 \mathrm{E}+04$ & $n / a$ & $\mathrm{n} / \mathrm{a}$ & $\mathrm{n} / \mathrm{a}$ & $\mathrm{n} / \mathrm{a}$ & 18.7 & \\
\hline S11T011063 & Oxalate & $\mathrm{ug} / \mathrm{mL}$ & 102 & $<0.0231$ & 577 & $\mathrm{n} / \mathrm{a}$ & $\mathrm{n} / \mathrm{a}$ & $\mathrm{n} / \mathrm{a}$ & $\mathrm{n} / \mathrm{a}$ & 23.1 & \\
\hline S11T011063 & Bromide & $\mathrm{ug} / \mathrm{mL}$ & 101 & $<0.0580$ & $<58.0$ & $\mathrm{n} / \mathrm{a}$ & $\mathrm{n} / \mathrm{a}$ & $\mathrm{n} / \mathrm{a}$ & $\mathrm{n} / \mathrm{a}$ & 58.0 & $\mathrm{U}$ \\
\hline S11T011063 & Nitrate & $\mathrm{ug} / \mathrm{mL}$ & 100 & 0.0709 & $1.85 \mathrm{E}+05$ & $\mathrm{n} / \mathrm{a}$ & $\mathrm{n} / \mathrm{a}$ & $\mathrm{n} / \mathrm{a}$ & $\mathrm{n} / \mathrm{a}$ & 208 & \\
\hline S11T011063 & Phosphate & $\mathrm{ug} / \mathrm{mL}$ & 101 & $<0.0167$ & $2.18 \mathrm{E}+03$ & $n / a$ & $\mathrm{n} / \mathrm{a}$ & $\mathrm{n} / \mathrm{a}$ & $\mathrm{n} / \mathrm{a}$ & 16.7 & \\
\hline S11T011063 & Silver & $\mathrm{ug} / \mathrm{mL}$ & 98.6 & $\mathrm{n} / \mathrm{a}$ & $<12.5$ & $\mathrm{n} / \mathrm{a}$ & $\mathrm{n} / \mathrm{a}$ & $\mathrm{n} / \mathrm{a}$ & $\mathrm{n} / \mathrm{a}$ & 12.5 & \\
\hline S11T011063 & Aluminum & $\mathrm{ug} / \mathrm{mL}$ & 101 & $<0.0300$ & $7.25 \mathrm{E}+03$ & $\mathrm{n} / \mathrm{a}$ & $\mathrm{n} / \mathrm{a}$ & $\mathrm{n} / \mathrm{a}$ & $\mathrm{n} / \mathrm{a}$ & 75.0 & \\
\hline S11T011063 & Arsenic & $\mathrm{ug} / \mathrm{mL}$ & 100 & $\mathrm{n} / \mathrm{a}$ & $<125$ & $\mathrm{n} / \mathrm{a}$ & $\mathrm{n} / \mathrm{a}$ & $\mathrm{n} / \mathrm{a}$ & $\mathrm{n} / \mathrm{a}$ & 125 & \\
\hline S11T011063 & Boron & $\mathrm{ug} / \mathrm{mL}$ & 99.3 & $\mathrm{n} / \mathrm{a}$ & $<75.0$ & $\mathrm{n} / \mathrm{a}$ & $\mathrm{n} / \mathrm{a}$ & $\mathrm{n} / \mathrm{a}$ & $\mathrm{n} / \mathrm{a}$ & 75.0 & \\
\hline S11T011063 & Barium & $\mathrm{ug} / \mathrm{mL}$ & 101 & $\mathrm{n} / \mathrm{a}$ & $<7.50$ & $\mathrm{n} / \mathrm{a}$ & $\mathrm{n} / \mathrm{a}$ & $\mathrm{n} / \mathrm{a}$ & $\mathrm{n} / \mathrm{a}$ & 7.50 & \\
\hline S11T011063 & Beryllium & $\mathrm{ug} / \mathrm{mL}$ & 98.9 & $\mathrm{n} / \mathrm{a}$ & $<2.50$ & $\mathrm{n} / \mathrm{a}$ & $\mathrm{n} / \mathrm{a}$ & $\mathrm{n} / \mathrm{a}$ & $\mathrm{n} / \mathrm{a}$ & 2.50 & \\
\hline S11T011063 & Bismuth & $\mathrm{ug} / \mathrm{mL}$ & 100 & $\mathrm{n} / \mathrm{a}$ & $<250$ & $\mathrm{n} / \mathrm{a}$ & $\mathrm{n} / \mathrm{a}$ & $\mathrm{n} / \mathrm{a}$ & $\mathrm{n} / \mathrm{a}$ & 250 & \\
\hline S11T011063 & Calcium & $\mathrm{ug} / \mathrm{mL}$ & 101 & $<0.0500$ & $<125$ & $\mathrm{n} / \mathrm{a}$ & $\mathrm{n} / \mathrm{a}$ & $\mathrm{n} / \mathrm{a}$ & $\mathrm{n} / \mathrm{a}$ & 125 & $\mathrm{U}$ \\
\hline S11T011063 & Cadmium & $\mathrm{ug} / \mathrm{mL}$ & 102 & $\mathrm{n} / \mathrm{a}$ & $<12.5$ & $\mathrm{n} / \mathrm{a}$ & $\mathrm{n} / \mathrm{a}$ & $\mathrm{n} / \mathrm{a}$ & $\mathrm{n} / \mathrm{a}$ & 12.5 & \\
\hline S11T011063 & Cerium & $\mathrm{ug} / \mathrm{mL}$ & 101 & $\mathrm{n} / \mathrm{a}$ & $<75.0$ & $\mathrm{n} / \mathrm{a}$ & $\mathrm{n} / \mathrm{a}$ & $\mathrm{n} / \mathrm{a}$ & $\mathrm{n} / \mathrm{a}$ & 75.0 & \\
\hline S11T011063 & Cobalt & $\mathrm{ug} / \mathrm{mL}$ & 101 & $\mathrm{n} / \mathrm{a}$ & $<25.0$ & $n / a$ & $\mathrm{n} / \mathrm{a}$ & $\mathrm{n} / \mathrm{a}$ & $\mathrm{n} / \mathrm{a}$ & 25.0 & \\
\hline S11T011063 & Chromium & $\mathrm{ug} / \mathrm{mL}$ & 101 & $<5.00 \mathrm{E}-03$ & 959 & $\mathrm{n} / \mathrm{a}$ & $\mathrm{n} / \mathrm{a}$ & $\mathrm{n} / \mathrm{a}$ & $\mathrm{n} / \mathrm{a}$ & 12.5 & \\
\hline S11T011063 & Copper & $\mathrm{ug} / \mathrm{mL}$ & 102 & $\mathrm{n} / \mathrm{a}$ & $<12.5$ & $\mathrm{n} / \mathrm{a}$ & $\mathrm{n} / \mathrm{a}$ & $\mathrm{n} / \mathrm{a}$ & $\mathrm{n} / \mathrm{a}$ & 12.5 & \\
\hline S11T011063 & Europium & $\mathrm{ug} / \mathrm{mL}$ & 95.4 & $\mathrm{n} / \mathrm{a}$ & $<12.5$ & $\mathrm{n} / \mathrm{a}$ & $\mathrm{n} / \mathrm{a}$ & $\mathrm{n} / \mathrm{a}$ & $\mathrm{n} / \mathrm{a}$ & 12.5 & \\
\hline S11T011063 & Iron & $\mathrm{ug} / \mathrm{mL}$ & 101 & $\mathrm{n} / \mathrm{a}$ & $<12.5$ & $\mathrm{n} / \mathrm{a}$ & $\mathrm{n} / \mathrm{a}$ & $\mathrm{n} / \mathrm{a}$ & $\mathrm{n} / \mathrm{a}$ & 12.5 & \\
\hline S11T011063 & Potassium & $\mathrm{ug} / \mathrm{mL}$ & 92.3 & $<0.500$ & $2.06 \mathrm{E}+03$ & $\mathrm{n} / \mathrm{a}$ & $\mathrm{n} / \mathrm{a}$ & $\mathrm{n} / \mathrm{a}$ & $\mathrm{n} / \mathrm{a}$ & $1.25 \mathrm{E}+03$ & $\mathrm{~J}$ \\
\hline S11T011063 & Lanthanum & $\mathrm{ug} / \mathrm{mL}$ & 99.5 & $\mathrm{n} / \mathrm{a}$ & $<7.50$ & $\mathrm{n} / \mathrm{a}$ & $\mathrm{n} / \mathrm{a}$ & $\mathrm{n} / \mathrm{a}$ & $\mathrm{n} / \mathrm{a}$ & 7.50 & \\
\hline
\end{tabular}


Table D-3. Centrifuged Liquid from Sample CON 2. (2 sheets)

Sample Number(s): S11T011063 (Test Sample CON 2)

Sample Group: 20111225

\begin{tabular}{|c|c|c|c|c|c|c|c|c|c|c|c|}
\hline Sample \# & Analyte & Unit & $\begin{array}{c}\text { Std } \\
\%-\operatorname{Rec}\end{array}$ & Blank & Result & Duplicate & Average & RPD & $\begin{array}{c}\text { Spk } \\
\% \text {-Rec }\end{array}$ & $\begin{array}{c}\text { Det } \\
\text { Limit }\end{array}$ & $\begin{array}{l}\text { Qual } \\
\text { Flags }\end{array}$ \\
\hline S11T011063 & Lithium & $\mathrm{ug} / \mathrm{mL}$ & 109 & $\mathrm{n} / \mathrm{a}$ & $<7.50$ & $\mathrm{n} / \mathrm{a}$ & $\mathrm{n} / \mathrm{a}$ & $\mathrm{n} / \mathrm{a}$ & $\mathrm{n} / \mathrm{a}$ & 7.50 & \\
\hline S11T011063 & Magnesium & $\mathrm{ug} / \mathrm{mL}$ & 102 & $\mathrm{n} / \mathrm{a}$ & $<125$ & $\mathrm{n} / \mathrm{a}$ & $\mathrm{n} / \mathrm{a}$ & $\mathrm{n} / \mathrm{a}$ & $\mathrm{n} / \mathrm{a}$ & 125 & \\
\hline S11T011063 & Manganese & $\mathrm{ug} / \mathrm{mL}$ & 100 & $\mathrm{n} / \mathrm{a}$ & $<7.50$ & $\mathrm{n} / \mathrm{a}$ & $\mathrm{n} / \mathrm{a}$ & $\mathrm{n} / \mathrm{a}$ & $\mathrm{n} / \mathrm{a}$ & 7.50 & \\
\hline S11T011063 & Molybdenum & $\mathrm{ug} / \mathrm{mL}$ & 98.8 & $\mathrm{n} / \mathrm{a}$ & 55.8 & $\mathrm{n} / \mathrm{a}$ & $\mathrm{n} / \mathrm{a}$ & $\mathrm{n} / \mathrm{a}$ & $\mathrm{n} / \mathrm{a}$ & 50.0 & \\
\hline S11T011063 & Sodium & $\mathrm{ug} / \mathrm{mL}$ & 106 & $<0.100$ & $1.67 \mathrm{E}+05$ & $\mathrm{n} / \mathrm{a}$ & $\mathrm{n} / \mathrm{a}$ & $\mathrm{n} / \mathrm{a}$ & $\mathrm{n} / \mathrm{a}$ & 250 & \\
\hline S11T011063 & Neodymium & $\mathrm{ug} / \mathrm{mL}$ & 100 & $\mathrm{n} / \mathrm{a}$ & $<25.0$ & $\mathrm{n} / \mathrm{a}$ & $\mathrm{n} / \mathrm{a}$ & $\mathrm{n} / \mathrm{a}$ & $\mathrm{n} / \mathrm{a}$ & 25.0 & \\
\hline S11T011063 & Nickel & $\mathrm{ug} / \mathrm{mL}$ & 101 & $\mathrm{n} / \mathrm{a}$ & $<50.0$ & $n / a$ & $n / a$ & $\mathrm{n} / \mathrm{a}$ & $\mathrm{n} / \mathrm{a}$ & 50.0 & \\
\hline S11T011063 & Phosphorus & $\mathrm{ug} / \mathrm{mL}$ & 102 & $<0.0500$ & 817 & $\mathrm{n} / \mathrm{a}$ & $\mathrm{n} / \mathrm{a}$ & $\mathrm{n} / \mathrm{a}$ & $\mathrm{n} / \mathrm{a}$ & 125 & $\mathrm{~J}$ \\
\hline S11T011063 & Lead & $\mathrm{ug} / \mathrm{mL}$ & 104 & $\mathrm{n} / \mathrm{a}$ & $<125$ & $\mathrm{n} / \mathrm{a}$ & $\mathrm{n} / \mathrm{a}$ & $\mathrm{n} / \mathrm{a}$ & $\mathrm{n} / \mathrm{a}$ & 125 & \\
\hline S11T011063 & Sulfur & $\mathrm{ug} / \mathrm{mL}$ & 98.4 & $<0.100$ & $5.21 \mathrm{E}+03$ & $\mathrm{n} / \mathrm{a}$ & $\mathrm{n} / \mathrm{a}$ & $\mathrm{n} / \mathrm{a}$ & $\mathrm{n} / \mathrm{a}$ & 250 & \\
\hline S11T011063 & Antimony & $\mathrm{ug} / \mathrm{mL}$ & 94.6 & $\mathrm{n} / \mathrm{a}$ & $<125$ & $\mathrm{n} / \mathrm{a}$ & $\mathrm{n} / \mathrm{a}$ & $\mathrm{n} / \mathrm{a}$ & $\mathrm{n} / \mathrm{a}$ & 125 & \\
\hline S11T011063 & Selenium & $\mathrm{ug} / \mathrm{mL}$ & 104 & $\mathrm{n} / \mathrm{a}$ & $<250$ & $\mathrm{n} / \mathrm{a}$ & $\mathrm{n} / \mathrm{a}$ & $\mathrm{n} / \mathrm{a}$ & $\mathrm{n} / \mathrm{a}$ & 250 & \\
\hline S11T011063 & Silicon & $\mathrm{ug} / \mathrm{mL}$ & 94.7 & $<0.0300$ & 182 & $\mathrm{n} / \mathrm{a}$ & $\mathrm{n} / \mathrm{a}$ & $\mathrm{n} / \mathrm{a}$ & $\mathrm{n} / \mathrm{a}$ & 75.0 & $\mathrm{~J}$ \\
\hline S11T011063 & Samarium & $\mathrm{ug} / \mathrm{mL}$ & 103 & $\mathrm{n} / \mathrm{a}$ & $<125$ & $\mathrm{n} / \mathrm{a}$ & $\mathrm{n} / \mathrm{a}$ & $\mathrm{n} / \mathrm{a}$ & $\mathrm{n} / \mathrm{a}$ & 125 & \\
\hline S11T011063 & Strontium & $\mathrm{ug} / \mathrm{mL}$ & 101 & $\mathrm{n} / \mathrm{a}$ & $<7.50$ & $\mathrm{n} / \mathrm{a}$ & $\mathrm{n} / \mathrm{a}$ & $\mathrm{n} / \mathrm{a}$ & $\mathrm{n} / \mathrm{a}$ & 7.50 & \\
\hline S11T011063 & Thorium & $\mathrm{ug} / \mathrm{mL}$ & 97.5 & $\mathrm{n} / \mathrm{a}$ & $<125$ & $n / a$ & $\mathrm{n} / \mathrm{a}$ & $\mathrm{n} / \mathrm{a}$ & $\mathrm{n} / \mathrm{a}$ & 125 & \\
\hline S11T011063 & Titanium & $\mathrm{ug} / \mathrm{mL}$ & 97.3 & $\mathrm{n} / \mathrm{a}$ & $<12.5$ & $\mathrm{n} / \mathrm{a}$ & $\mathrm{n} / \mathrm{a}$ & $\mathrm{n} / \mathrm{a}$ & $\mathrm{n} / \mathrm{a}$ & 12.5 & \\
\hline S11T011063 & Thallium & $\mathrm{ug} / \mathrm{mL}$ & 96.2 & $\mathrm{n} / \mathrm{a}$ & $<250$ & $\mathrm{n} / \mathrm{a}$ & $\mathrm{n} / \mathrm{a}$ & $\mathrm{n} / \mathrm{a}$ & $\mathrm{n} / \mathrm{a}$ & 250 & \\
\hline S11T011063 & Uranium & $\mathrm{ug} / \mathrm{mL}$ & 101 & $\mathrm{n} / \mathrm{a}$ & $<250$ & $\mathrm{n} / \mathrm{a}$ & $\mathrm{n} / \mathrm{a}$ & $\mathrm{n} / \mathrm{a}$ & $\mathrm{n} / \mathrm{a}$ & 250 & \\
\hline S11T011063 & Vanadium & $\mathrm{ug} / \mathrm{mL}$ & 101 & $\mathrm{n} / \mathrm{a}$ & $<12.5$ & $\mathrm{n} / \mathrm{a}$ & $\mathrm{n} / \mathrm{a}$ & $\mathrm{n} / \mathrm{a}$ & $\mathrm{n} / \mathrm{a}$ & 12.5 & \\
\hline S11T011063 & Yttrium & $\mathrm{ug} / \mathrm{mL}$ & 94.7 & $\mathrm{n} / \mathrm{a}$ & $<5.00$ & $\mathrm{n} / \mathrm{a}$ & $\mathrm{n} / \mathrm{a}$ & $\mathrm{n} / \mathrm{a}$ & $\mathrm{n} / \mathrm{a}$ & 5.00 & \\
\hline S11T011063 & Zinc & $\mathrm{ug} / \mathrm{mL}$ & 99.9 & $\mathrm{n} / \mathrm{a}$ & $<12.5$ & $\mathrm{n} / \mathrm{a}$ & $\mathrm{n} / \mathrm{a}$ & $\mathrm{n} / \mathrm{a}$ & $\mathrm{n} / \mathrm{a}$ & 12.5 & \\
\hline S11T011063 & Zirconium & $\mathrm{ug} / \mathrm{mL}$ & 98.9 & $\mathrm{n} / \mathrm{a}$ & $<12.5$ & $\mathrm{n} / \mathrm{a}$ & $\mathrm{n} / \mathrm{a}$ & $\mathrm{n} / \mathrm{a}$ & $\mathrm{n} / \mathrm{a}$ & 12.5 & \\
\hline S11T011063 & Hydroxide & $\mathrm{ug} / \mathrm{mL}$ & 105 & $<41.7$ & $1.6 \mathrm{E}+04$ & $\mathrm{n} / \mathrm{a}$ & $\mathrm{n} / \mathrm{a}$ & $\mathrm{n} / \mathrm{a}$ & $\mathrm{n} / \mathrm{a}$ & 550 & \\
\hline S11T011063 & Specific gravity & unitless & 100.5 & $\mathrm{n} / \mathrm{a}$ & 1.386 & $\mathrm{n} / \mathrm{a}$ & $\mathrm{n} / \mathrm{a}$ & $\mathrm{n} / \mathrm{a}$ & $\mathrm{n} / \mathrm{a}$ & $1.00 \mathrm{E}-03$ & \\
\hline S11T011063 & Total organic carbon & $\mathrm{ug} / \mathrm{mL}$ & 97.9 & $<20.0$ & $1.04 \mathrm{E}+03$ & $1.05 \mathrm{E}+03$ & $1.04 \mathrm{E}+03$ & 0.957 & 101 & 200 & $\mathrm{~J}$ \\
\hline S11T011063 & Total inorganic carbon & $\mathrm{ug} / \mathrm{mL}$ & 80.0 & $<7.00$ & $8.49 \mathrm{E}+03$ & $8.51 \mathrm{E}+03$ & $8.50 \mathrm{E}+03$ & 0.235 & 111 & 7.00 & \\
\hline
\end{tabular}


Table D-4. Centrifuged Liquid from Sample CON 3. (2 sheets)

Sample Number(s): S11T011064 (Test Sample CON 3)

Sample Group: 20111225

\begin{tabular}{|c|c|c|c|c|c|c|c|c|c|c|c|}
\hline Sample \# & Analyte & Unit & $\begin{array}{c}\text { Std } \\
\%-\operatorname{Rec}\end{array}$ & Blank & Result & Duplicate & Average & RPD & $\begin{array}{c}\text { Spk } \\
\text { \%-Rec }\end{array}$ & $\begin{array}{c}\text { Det } \\
\text { Limit }\end{array}$ & $\begin{array}{l}\text { Qual } \\
\text { Flags }\end{array}$ \\
\hline S11T011064 & Fluoride & $\mathrm{ug} / \mathrm{mL}$ & 103 & $<1.61 \mathrm{E}-03$ & 337 & $\mathrm{n} / \mathrm{a}$ & $\mathrm{n} / \mathrm{a}$ & $\mathrm{n} / \mathrm{a}$ & $\mathrm{n} / \mathrm{a}$ & 1.61 & \\
\hline S11T011064 & Glycolate & $\mathrm{ug} / \mathrm{mL}$ & 101 & $<9.37 \mathrm{E}-03$ & 312 & $\mathrm{n} / \mathrm{a}$ & $\mathrm{n} / \mathrm{a}$ & $\mathrm{n} / \mathrm{a}$ & $\mathrm{n} / \mathrm{a}$ & 9.37 & \\
\hline S11T011064 & Acetate & $\mathrm{ug} / \mathrm{mL}$ & 101 & $<6.04 \mathrm{E}-03$ & 351 & $\mathrm{n} / \mathrm{a}$ & $\mathrm{n} / \mathrm{a}$ & $\mathrm{n} / \mathrm{a}$ & $\mathrm{n} / \mathrm{a}$ & 6.04 & \\
\hline S11T011064 & Formate & $\mathrm{ug} / \mathrm{mL}$ & 101 & $<4.67 \mathrm{E}-03$ & $1.08 \mathrm{E}+03$ & $\mathrm{n} / \mathrm{a}$ & $\mathrm{n} / \mathrm{a}$ & $\mathrm{n} / \mathrm{a}$ & $\mathrm{n} / \mathrm{a}$ & 4.67 & \\
\hline S11T011064 & Chloride & $\mathrm{ug} / \mathrm{mL}$ & 101 & 0.0131 & $2.31 \mathrm{E}+03$ & $\mathrm{n} / \mathrm{a}$ & $\mathrm{n} / \mathrm{a}$ & $\mathrm{n} / \mathrm{a}$ & $\mathrm{n} / \mathrm{a}$ & 9.98 & \\
\hline S11T011064 & Nitrite & $\mathrm{ug} / \mathrm{mL}$ & 101 & $<0.0192$ & $5.00 \mathrm{E}+04$ & $\mathrm{n} / \mathrm{a}$ & $\mathrm{n} / \mathrm{a}$ & $\mathrm{n} / \mathrm{a}$ & $\mathrm{n} / \mathrm{a}$ & 96.0 & \\
\hline S11T011064 & Sulfate & $\mathrm{ug} / \mathrm{mL}$ & 102 & $<0.0187$ & $1.42 \mathrm{E}+04$ & $\mathrm{n} / \mathrm{a}$ & $\mathrm{n} / \mathrm{a}$ & $\mathrm{n} / \mathrm{a}$ & $\mathrm{n} / \mathrm{a}$ & 18.7 & \\
\hline S11T011064 & Oxalate & $\mathrm{ug} / \mathrm{mL}$ & 102 & $<0.0231$ & 406 & $\mathrm{n} / \mathrm{a}$ & $\mathrm{n} / \mathrm{a}$ & $\mathrm{n} / \mathrm{a}$ & $\mathrm{n} / \mathrm{a}$ & 23.1 & \\
\hline S11T011064 & Bromide & $\mathrm{ug} / \mathrm{mL}$ & 101 & $<0.0580$ & $<58.0$ & $\mathrm{n} / \mathrm{a}$ & $\mathrm{n} / \mathrm{a}$ & $\mathrm{n} / \mathrm{a}$ & $\mathrm{n} / \mathrm{a}$ & 58.0 & $\bar{U}$ \\
\hline S11T011064 & Nitrate & $\mathrm{ug} / \mathrm{mL}$ & 100 & 0.0709 & $1.97 \mathrm{E}+05$ & $\mathrm{n} / \mathrm{a}$ & $\mathrm{n} / \mathrm{a}$ & $\mathrm{n} / \mathrm{a}$ & $\mathrm{n} / \mathrm{a}$ & 208 & \\
\hline S11T011064 & Phosphate & $\mathrm{ug} / \mathrm{mL}$ & 101 & $<0.0167$ & $2.12 \mathrm{E}+03$ & $\mathrm{n} / \mathrm{a}$ & $\mathrm{n} / \mathrm{a}$ & $\mathrm{n} / \mathrm{a}$ & $\mathrm{n} / \mathrm{a}$ & 16.7 & \\
\hline S11T011064 & Silver & $\mathrm{ug} / \mathrm{mL}$ & 98.6 & $\mathrm{n} / \mathrm{a}$ & $<12.5$ & $\mathrm{n} / \mathrm{a}$ & $\mathrm{n} / \mathrm{a}$ & $\mathrm{n} / \mathrm{a}$ & $\mathrm{n} / \mathrm{a}$ & 12.5 & \\
\hline S11T011064 & Aluminum & $\mathrm{ug} / \mathrm{mL}$ & 101 & $<0.0300$ & $8.10 \mathrm{E}+03$ & $\mathrm{n} / \mathrm{a}$ & $\mathrm{n} / \mathrm{a}$ & $\mathrm{n} / \mathrm{a}$ & $\mathrm{n} / \mathrm{a}$ & 75.0 & \\
\hline S11T011064 & Arsenic & $\mathrm{ug} / \mathrm{mL}$ & 100 & $\mathrm{n} / \mathrm{a}$ & $<125$ & $\mathrm{n} / \mathrm{a}$ & $\mathrm{n} / \mathrm{a}$ & $\mathrm{n} / \mathrm{a}$ & $\mathrm{n} / \mathrm{a}$ & 125 & \\
\hline S11T011064 & Boron & $\mathrm{ug} / \mathrm{mL}$ & 99.3 & $\mathrm{n} / \mathrm{a}$ & $<75.0$ & $\mathrm{n} / \mathrm{a}$ & $\mathrm{n} / \mathrm{a}$ & $\mathrm{n} / \mathrm{a}$ & $\mathrm{n} / \mathrm{a}$ & 75.0 & \\
\hline S11T011064 & Barium & $\mathrm{ug} / \mathrm{mL}$ & 101 & $\mathrm{n} / \mathrm{a}$ & $<7.50$ & $\mathrm{n} / \mathrm{a}$ & $\mathrm{n} / \mathrm{a}$ & $\mathrm{n} / \mathrm{a}$ & $\mathrm{n} / \mathrm{a}$ & 7.50 & \\
\hline S11T011064 & Beryllium & $\mathrm{ug} / \mathrm{mL}$ & 98.9 & $\mathrm{n} / \mathrm{a}$ & $<2.50$ & $\mathrm{n} / \mathrm{a}$ & $\mathrm{n} / \mathrm{a}$ & $\mathrm{n} / \mathrm{a}$ & $\mathrm{n} / \mathrm{a}$ & 2.50 & \\
\hline S11T011064 & Bismuth & $\mathrm{ug} / \mathrm{mL}$ & 100 & $\mathrm{n} / \mathrm{a}$ & $<250$ & $\mathrm{n} / \mathrm{a}$ & $\mathrm{n} / \mathrm{a}$ & $\mathrm{n} / \mathrm{a}$ & $\mathrm{n} / \mathrm{a}$ & 250 & \\
\hline S11T011064 & Calcium & $\mathrm{ug} / \mathrm{mL}$ & 101 & $<0.0500$ & $<125$ & $\mathrm{n} / \mathrm{a}$ & $\mathrm{n} / \mathrm{a}$ & $\mathrm{n} / \mathrm{a}$ & $\mathrm{n} / \mathrm{a}$ & 125 & $\bar{U}$ \\
\hline S11T011064 & Cadmium & $\mathrm{ug} / \mathrm{mL}$ & 102 & $\mathrm{n} / \mathrm{a}$ & $<12.5$ & $\mathrm{n} / \mathrm{a}$ & $\mathrm{n} / \mathrm{a}$ & $\mathrm{n} / \mathrm{a}$ & $\mathrm{n} / \mathrm{a}$ & 12.5 & \\
\hline S11T011064 & Cerium & $\mathrm{ug} / \mathrm{mL}$ & 101 & $\mathrm{n} / \mathrm{a}$ & $<75.0$ & $\mathrm{n} / \mathrm{a}$ & $\mathrm{n} / \mathrm{a}$ & $\mathrm{n} / \mathrm{a}$ & $\mathrm{n} / \mathrm{a}$ & 75.0 & \\
\hline S11T011064 & Cobalt & $\mathrm{ug} / \mathrm{mL}$ & 101 & $\mathrm{n} / \mathrm{a}$ & $<25.0$ & $\mathrm{n} / \mathrm{a}$ & $\mathrm{n} / \mathrm{a}$ & $\mathrm{n} / \mathrm{a}$ & $\mathrm{n} / \mathrm{a}$ & 25.0 & \\
\hline S11T011064 & Chromium & $\mathrm{ug} / \mathrm{mL}$ & 101 & $<5.00 \mathrm{E}-03$ & $1.08 \mathrm{E}+03$ & $\mathrm{n} / \mathrm{a}$ & $\mathrm{n} / \mathrm{a}$ & $\mathrm{n} / \mathrm{a}$ & $\mathrm{n} / \mathrm{a}$ & 12.5 & \\
\hline S11T011064 & Copper & $\mathrm{ug} / \mathrm{mL}$ & 102 & $\mathrm{n} / \mathrm{a}$ & $<12.5$ & $\mathrm{n} / \mathrm{a}$ & $\mathrm{n} / \mathrm{a}$ & $\mathrm{n} / \mathrm{a}$ & $\mathrm{n} / \mathrm{a}$ & 12.5 & \\
\hline S11T011064 & Europium & $\mathrm{ug} / \mathrm{mL}$ & 95.4 & $\mathrm{n} / \mathrm{a}$ & $<12.5$ & $\mathrm{n} / \mathrm{a}$ & $\mathrm{n} / \mathrm{a}$ & $\mathrm{n} / \mathrm{a}$ & $\mathrm{n} / \mathrm{a}$ & 12.5 & \\
\hline S11T011064 & Iron & $\mathrm{ug} / \mathrm{mL}$ & 101 & $\mathrm{n} / \mathrm{a}$ & $<12.5$ & $\mathrm{n} / \mathrm{a}$ & $\mathrm{n} / \mathrm{a}$ & $\mathrm{n} / \mathrm{a}$ & $\mathrm{n} / \mathrm{a}$ & 12.5 & \\
\hline S11T011064 & Potassium & $\mathrm{ug} / \mathrm{mL}$ & 92.3 & $<0.500$ & $2.85 \mathrm{E}+03$ & $\mathrm{n} / \mathrm{a}$ & $\mathrm{n} / \mathrm{a}$ & $\mathrm{n} / \mathrm{a}$ & $\mathrm{n} / \mathrm{a}$ & $1.25 \mathrm{E}+03$ & $\mathrm{~J}$ \\
\hline S11T011064 & Lanthanum & $\mathrm{ug} / \mathrm{mL}$ & 99.5 & $\mathrm{n} / \mathrm{a}$ & $<7.50$ & $\mathrm{n} / \mathrm{a}$ & $\mathrm{n} / \mathrm{a}$ & $\mathrm{n} / \mathrm{a}$ & $\mathrm{n} / \mathrm{a}$ & 7.50 & \\
\hline
\end{tabular}


Table D-4. Centrifuged Liquid from Sample CON 3. (2 sheets)

Sample Number(s): S11T011064 (Test Sample CON 3)

Sample Group: 20111225

\begin{tabular}{|c|c|c|c|c|c|c|c|c|c|c|c|}
\hline Sample \# & Analyte & Unit & $\begin{array}{c}\text { Std } \\
\%-\operatorname{Rec}\end{array}$ & Blank & Result & Duplicate & Average & RPD & $\begin{array}{c}\text { Spk } \\
\text { \%-Rec }\end{array}$ & $\begin{array}{c}\text { Det } \\
\text { Limit }\end{array}$ & $\begin{array}{l}\text { Qual } \\
\text { Flags }\end{array}$ \\
\hline S11T011064 & Lithium & $\mathrm{ug} / \mathrm{mL}$ & 109 & $\mathrm{n} / \mathrm{a}$ & $<7.50$ & $\mathrm{n} / \mathrm{a}$ & $\mathrm{n} / \mathrm{a}$ & $n / a$ & $\mathrm{n} / \mathrm{a}$ & 7.50 & \\
\hline S11T011064 & Magnesium & $\mathrm{ug} / \mathrm{mL}$ & 102 & $\mathrm{n} / \mathrm{a}$ & $<125$ & $\mathrm{n} / \mathrm{a}$ & $\mathrm{n} / \mathrm{a}$ & $\mathrm{n} / \mathrm{a}$ & $\mathrm{n} / \mathrm{a}$ & 125 & \\
\hline S11T011064 & Manganese & $\mathrm{ug} / \mathrm{mL}$ & 100 & $\mathrm{n} / \mathrm{a}$ & $<7.50$ & $\mathrm{n} / \mathrm{a}$ & $\mathrm{n} / \mathrm{a}$ & $\mathrm{n} / \mathrm{a}$ & $\mathrm{n} / \mathrm{a}$ & 7.50 & \\
\hline S11T011064 & Molybdenum & $\mathrm{ug} / \mathrm{mL}$ & 98.8 & $\mathrm{n} / \mathrm{a}$ & 64.2 & $\mathrm{n} / \mathrm{a}$ & $\mathrm{n} / \mathrm{a}$ & $\mathrm{n} / \mathrm{a}$ & $\mathrm{n} / \mathrm{a}$ & 50.0 & \\
\hline S11T011064 & Sodium & $\mathrm{ug} / \mathrm{mL}$ & 106 & $<0.100$ & $1.82 \mathrm{E}+05$ & $\mathrm{n} / \mathrm{a}$ & $\mathrm{n} / \mathrm{a}$ & $n / a$ & $\mathrm{n} / \mathrm{a}$ & 250 & \\
\hline S11T011064 & Neodymium & $\mathrm{ug} / \mathrm{mL}$ & 100 & $\mathrm{n} / \mathrm{a}$ & $<25.0$ & $\mathrm{n} / \mathrm{a}$ & $\mathrm{n} / \mathrm{a}$ & $\mathrm{n} / \mathrm{a}$ & $\mathrm{n} / \mathrm{a}$ & 25.0 & \\
\hline S11T011064 & Nickel & $\mathrm{ug} / \mathrm{mL}$ & 101 & $\mathrm{n} / \mathrm{a}$ & $<50.0$ & $\mathrm{n} / \mathrm{a}$ & $\mathrm{n} / \mathrm{a}$ & $\mathrm{n} / \mathrm{a}$ & $\mathrm{n} / \mathrm{a}$ & 50.0 & \\
\hline S11T011064 & Phosphorus & $\mathrm{ug} / \mathrm{mL}$ & 102 & $<0.0500$ & 676 & $\mathrm{n} / \mathrm{a}$ & $\mathrm{n} / \mathrm{a}$ & $\mathrm{n} / \mathrm{a}$ & $\mathrm{n} / \mathrm{a}$ & 125 & $\mathrm{~J}$ \\
\hline S11T011064 & Lead & $\mathrm{ug} / \mathrm{mL}$ & 104 & $\mathrm{n} / \mathrm{a}$ & $<125$ & $\mathrm{n} / \mathrm{a}$ & $\mathrm{n} / \mathrm{a}$ & $\mathrm{n} / \mathrm{a}$ & $\mathrm{n} / \mathrm{a}$ & 125 & \\
\hline S11T011064 & Sulfur & $\mathrm{ug} / \mathrm{mL}$ & 98.4 & $<0.100$ & $5.43 \mathrm{E}+03$ & $\mathrm{n} / \mathrm{a}$ & $\mathrm{n} / \mathrm{a}$ & $\mathrm{n} / \mathrm{a}$ & $\mathrm{n} / \mathrm{a}$ & 250 & \\
\hline S11T011064 & Antimony & $\mathrm{ug} / \mathrm{mL}$ & 94.6 & $\mathrm{n} / \mathrm{a}$ & $<125$ & $\mathrm{n} / \mathrm{a}$ & $\mathrm{n} / \mathrm{a}$ & $n / a$ & $\mathrm{n} / \mathrm{a}$ & 125 & \\
\hline S11T011064 & Selenium & $\mathrm{ug} / \mathrm{mL}$ & 104 & $\mathrm{n} / \mathrm{a}$ & $<250$ & $\mathrm{n} / \mathrm{a}$ & $\mathrm{n} / \mathrm{a}$ & $\mathrm{n} / \mathrm{a}$ & $\mathrm{n} / \mathrm{a}$ & 250 & \\
\hline S11T011064 & Silicon & $\mathrm{ug} / \mathrm{mL}$ & 94.7 & $<0.0300$ & 263 & $\mathrm{n} / \mathrm{a}$ & $\mathrm{n} / \mathrm{a}$ & $\mathrm{n} / \mathrm{a}$ & $\mathrm{n} / \mathrm{a}$ & 75.0 & $\mathrm{~J}$ \\
\hline S11T011064 & Samarium & $\mathrm{ug} / \mathrm{mL}$ & 103 & $\mathrm{n} / \mathrm{a}$ & $<125$ & $\mathrm{n} / \mathrm{a}$ & $\mathrm{n} / \mathrm{a}$ & $\mathrm{n} / \mathrm{a}$ & $\mathrm{n} / \mathrm{a}$ & 125 & \\
\hline S11T011064 & Strontium & $\mathrm{ug} / \mathrm{mL}$ & 101 & $\mathrm{n} / \mathrm{a}$ & $<7.50$ & $\mathrm{n} / \mathrm{a}$ & $\mathrm{n} / \mathrm{a}$ & $\mathrm{n} / \mathrm{a}$ & $\mathrm{n} / \mathrm{a}$ & 7.50 & \\
\hline S11T011064 & Thorium & $\mathrm{ug} / \mathrm{mL}$ & 97.5 & $\mathrm{n} / \mathrm{a}$ & $<125$ & $\mathrm{n} / \mathrm{a}$ & $\mathrm{n} / \mathrm{a}$ & $\mathrm{n} / \mathrm{a}$ & $\mathrm{n} / \mathrm{a}$ & 125 & \\
\hline S11T011064 & Titanium & $\mathrm{ug} / \mathrm{mL}$ & 97.3 & $\mathrm{n} / \mathrm{a}$ & $<12.5$ & $\mathrm{n} / \mathrm{a}$ & $\mathrm{n} / \mathrm{a}$ & $\mathrm{n} / \mathrm{a}$ & $\mathrm{n} / \mathrm{a}$ & 12.5 & \\
\hline S11T011064 & Thallium & $\mathrm{ug} / \mathrm{mL}$ & 96.2 & $\mathrm{n} / \mathrm{a}$ & $<250$ & $\mathrm{n} / \mathrm{a}$ & $\mathrm{n} / \mathrm{a}$ & $\mathrm{n} / \mathrm{a}$ & $\mathrm{n} / \mathrm{a}$ & 250 & \\
\hline S11T011064 & Uranium & $\mathrm{ug} / \mathrm{mL}$ & 101 & $\mathrm{n} / \mathrm{a}$ & $<250$ & $\mathrm{n} / \mathrm{a}$ & $\mathrm{n} / \mathrm{a}$ & $\mathrm{n} / \mathrm{a}$ & $\mathrm{n} / \mathrm{a}$ & 250 & \\
\hline S11T011064 & Vanadium & $\mathrm{ug} / \mathrm{mL}$ & 101 & $\mathrm{n} / \mathrm{a}$ & $<12.5$ & $\mathrm{n} / \mathrm{a}$ & $\mathrm{n} / \mathrm{a}$ & $\mathrm{n} / \mathrm{a}$ & $\mathrm{n} / \mathrm{a}$ & 12.5 & \\
\hline S11T011064 & Yttrium & $\mathrm{ug} / \mathrm{mL}$ & 94.7 & $\mathrm{n} / \mathrm{a}$ & $<5.00$ & $\mathrm{n} / \mathrm{a}$ & $\mathrm{n} / \mathrm{a}$ & $\mathrm{n} / \mathrm{a}$ & $\mathrm{n} / \mathrm{a}$ & 5.00 & \\
\hline S11T011064 & Zinc & $\mathrm{ug} / \mathrm{mL}$ & 99.9 & $\mathrm{n} / \mathrm{a}$ & $<12.5$ & $\mathrm{n} / \mathrm{a}$ & $\mathrm{n} / \mathrm{a}$ & $\mathrm{n} / \mathrm{a}$ & $\mathrm{n} / \mathrm{a}$ & 12.5 & \\
\hline S11T011064 & Zirconium & $\mathrm{ug} / \mathrm{mL}$ & 98.9 & $\mathrm{n} / \mathrm{a}$ & $<12.5$ & $\mathrm{n} / \mathrm{a}$ & $\mathrm{n} / \mathrm{a}$ & $\mathrm{n} / \mathrm{a}$ & $\mathrm{n} / \mathrm{a}$ & 12.5 & \\
\hline S11T011064 & Hydroxide & $\mathrm{ug} / \mathrm{mL}$ & 105 & $<41.7$ & $1.8 \mathrm{E}+04$ & $\mathrm{n} / \mathrm{a}$ & $\mathrm{n} / \mathrm{a}$ & $\mathrm{n} / \mathrm{a}$ & $\mathrm{n} / \mathrm{a}$ & 550 & \\
\hline S11T011064 & Specific gravity & unitless & 100.5 & $\mathrm{n} / \mathrm{a}$ & 1.313 & $\mathrm{n} / \mathrm{a}$ & $\mathrm{n} / \mathrm{a}$ & $\mathrm{n} / \mathrm{a}$ & $\mathrm{n} / \mathrm{a}$ & $1.00 \mathrm{E}-03$ & \\
\hline S11T011064 & Total organic carbon & $\mathrm{ug} / \mathrm{mL}$ & 97.9 & $<20.0$ & $1.11 \mathrm{E}+03$ & $\mathrm{n} / \mathrm{a}$ & $\mathrm{n} / \mathrm{a}$ & $\mathrm{n} / \mathrm{a}$ & $\mathrm{n} / \mathrm{a}$ & 200 & $\mathrm{~J}$ \\
\hline S11T011064 & Total inorganic carbon & $\mathrm{ug} / \mathrm{mL}$ & 80.0 & $<7.00$ & $6.68 \mathrm{E}+03$ & $\mathrm{n} / \mathrm{a}$ & $\mathrm{n} / \mathrm{a}$ & $\mathrm{n} / \mathrm{a}$ & $\mathrm{n} / \mathrm{a}$ & 70.0 & \\
\hline
\end{tabular}


Table D-5. Centrifuged Liquid from Sample CON 4. (2 sheets)

Sample Number(s): S11T011065 (Test Sample CON 4)

Sample Group: 20111225

\begin{tabular}{|c|c|c|c|c|c|c|c|c|c|c|c|}
\hline Sample \# & Analyte & Unit & $\begin{array}{c}\text { Std } \\
\%-\operatorname{Rec}\end{array}$ & Blank & Result & Duplicate & Average & RPD & $\begin{array}{c}\text { Spk } \\
\text { \%-Rec }\end{array}$ & $\begin{array}{c}\text { Det } \\
\text { Limit }\end{array}$ & $\begin{array}{l}\text { Qual } \\
\text { Flags }\end{array}$ \\
\hline S11T011065 & Fluoride & $\mathrm{ug} / \mathrm{mL}$ & 103 & $<1.61 \mathrm{E}-03$ & 376 & $\mathrm{n} / \mathrm{a}$ & $\mathrm{n} / \mathrm{a}$ & $\mathrm{n} / \mathrm{a}$ & $\mathrm{n} / \mathrm{a}$ & 1.61 & \\
\hline S11T011065 & Glycolate & $\mathrm{ug} / \mathrm{mL}$ & 101 & $<9.37 \mathrm{E}-03$ & 331 & $\mathrm{n} / \mathrm{a}$ & $\mathrm{n} / \mathrm{a}$ & $\mathrm{n} / \mathrm{a}$ & $\mathrm{n} / \mathrm{a}$ & 9.37 & \\
\hline S11T011065 & Acetate & $\mathrm{ug} / \mathrm{mL}$ & 101 & $<6.04 \mathrm{E}-03$ & 373 & $\mathrm{n} / \mathrm{a}$ & $\mathrm{n} / \mathrm{a}$ & $\mathrm{n} / \mathrm{a}$ & $\mathrm{n} / \mathrm{a}$ & 6.04 & \\
\hline S11T011065 & Formate & $\mathrm{ug} / \mathrm{mL}$ & 101 & $<4.67 \mathrm{E}-03$ & $1.15 \mathrm{E}+03$ & $\mathrm{n} / \mathrm{a}$ & $\mathrm{n} / \mathrm{a}$ & $\mathrm{n} / \mathrm{a}$ & $\mathrm{n} / \mathrm{a}$ & 4.67 & \\
\hline S11T011065 & Chloride & $\mathrm{ug} / \mathrm{mL}$ & 101 & 0.0131 & $2.45 \mathrm{E}+03$ & $\mathrm{n} / \mathrm{a}$ & $\mathrm{n} / \mathrm{a}$ & $\mathrm{n} / \mathrm{a}$ & $\mathrm{n} / \mathrm{a}$ & 9.98 & \\
\hline S11T011065 & Nitrite & $\mathrm{ug} / \mathrm{mL}$ & 101 & $<0.0192$ & $5.32 \mathrm{E}+04$ & $\mathrm{n} / \mathrm{a}$ & $\mathrm{n} / \mathrm{a}$ & $\mathrm{n} / \mathrm{a}$ & $\mathrm{n} / \mathrm{a}$ & 96.0 & \\
\hline S11T011065 & Sulfate & $\mathrm{ug} / \mathrm{mL}$ & 102 & $<0.0187$ & $1.57 \mathrm{E}+04$ & $\mathrm{n} / \mathrm{a}$ & $\mathrm{n} / \mathrm{a}$ & $\mathrm{n} / \mathrm{a}$ & $\mathrm{n} / \mathrm{a}$ & 18.7 & \\
\hline S11T011065 & Oxalate & $\mathrm{ug} / \mathrm{mL}$ & 102 & $<0.0231$ & 365 & $\mathrm{n} / \mathrm{a}$ & $\mathrm{n} / \mathrm{a}$ & $\mathrm{n} / \mathrm{a}$ & $\mathrm{n} / \mathrm{a}$ & 23.1 & \\
\hline S11T011065 & Bromide & $\mathrm{ug} / \mathrm{mL}$ & 101 & $<0.0580$ & $<58.0$ & $\mathrm{n} / \mathrm{a}$ & $\mathrm{n} / \mathrm{a}$ & $\mathrm{n} / \mathrm{a}$ & $\mathrm{n} / \mathrm{a}$ & 58.0 & $\mathrm{U}$ \\
\hline S11T011065 & Nitrate & $\mathrm{ug} / \mathrm{mL}$ & 100 & 0.0709 & $2.11 \mathrm{E}+05$ & $\mathrm{n} / \mathrm{a}$ & $\mathrm{n} / \mathrm{a}$ & $\mathrm{n} / \mathrm{a}$ & $\mathrm{n} / \mathrm{a}$ & 208 & \\
\hline S11T011065 & Phosphate & $\mathrm{ug} / \mathrm{mL}$ & 101 & $<0.0167$ & $1.25 \mathrm{E}+03$ & $\mathrm{n} / \mathrm{a}$ & $\mathrm{n} / \mathrm{a}$ & $\mathrm{n} / \mathrm{a}$ & $\mathrm{n} / \mathrm{a}$ & 16.7 & \\
\hline S11T011065 & Silver & $\mathrm{ug} / \mathrm{mL}$ & 98.6 & $\mathrm{n} / \mathrm{a}$ & $<12.5$ & $\mathrm{n} / \mathrm{a}$ & $\mathrm{n} / \mathrm{a}$ & $\mathrm{n} / \mathrm{a}$ & $\mathrm{n} / \mathrm{a}$ & 12.5 & \\
\hline S11T011065 & Aluminum & $\mathrm{ug} / \mathrm{mL}$ & 101 & $<0.0300$ & $8.37 \mathrm{E}+03$ & $\mathrm{n} / \mathrm{a}$ & $\mathrm{n} / \mathrm{a}$ & $\mathrm{n} / \mathrm{a}$ & $\mathrm{n} / \mathrm{a}$ & 75.0 & \\
\hline S11T011065 & Arsenic & $\mathrm{ug} / \mathrm{mL}$ & 100 & $\mathrm{n} / \mathrm{a}$ & $<125$ & $\mathrm{n} / \mathrm{a}$ & $\mathrm{n} / \mathrm{a}$ & $\mathrm{n} / \mathrm{a}$ & $\mathrm{n} / \mathrm{a}$ & 125 & \\
\hline S11T011065 & Boron & $\mathrm{ug} / \mathrm{mL}$ & 99.3 & $\mathrm{n} / \mathrm{a}$ & $<75.0$ & $\mathrm{n} / \mathrm{a}$ & $\mathrm{n} / \mathrm{a}$ & $\mathrm{n} / \mathrm{a}$ & $\mathrm{n} / \mathrm{a}$ & 75.0 & \\
\hline S11T011065 & Barium & $\mathrm{ug} / \mathrm{mL}$ & 101 & $\mathrm{n} / \mathrm{a}$ & $<7.50$ & $\mathrm{n} / \mathrm{a}$ & $\mathrm{n} / \mathrm{a}$ & $\mathrm{n} / \mathrm{a}$ & $\mathrm{n} / \mathrm{a}$ & 7.50 & \\
\hline S11T011065 & Beryllium & $\mathrm{ug} / \mathrm{mL}$ & 98.9 & $\mathrm{n} / \mathrm{a}$ & $<2.50$ & $\mathrm{n} / \mathrm{a}$ & $\mathrm{n} / \mathrm{a}$ & $\mathrm{n} / \mathrm{a}$ & $\mathrm{n} / \mathrm{a}$ & 2.50 & \\
\hline S11T011065 & Bismuth & $\mathrm{ug} / \mathrm{mL}$ & 100 & $\mathrm{n} / \mathrm{a}$ & $<250$ & $\mathrm{n} / \mathrm{a}$ & $\mathrm{n} / \mathrm{a}$ & $\mathrm{n} / \mathrm{a}$ & $\mathrm{n} / \mathrm{a}$ & 250 & \\
\hline S11T011065 & Calcium & $\mathrm{ug} / \mathrm{mL}$ & 101 & $<0.0500$ & $<125$ & $\mathrm{n} / \mathrm{a}$ & $\mathrm{n} / \mathrm{a}$ & $\mathrm{n} / \mathrm{a}$ & $\mathrm{n} / \mathrm{a}$ & 125 & $\mathrm{U}$ \\
\hline S11T011065 & Cadmium & $\mathrm{ug} / \mathrm{mL}$ & 102 & $\mathrm{n} / \mathrm{a}$ & $<12.5$ & $\mathrm{n} / \mathrm{a}$ & $\mathrm{n} / \mathrm{a}$ & $\mathrm{n} / \mathrm{a}$ & $\mathrm{n} / \mathrm{a}$ & 12.5 & \\
\hline S11T011065 & Cerium & $\mathrm{ug} / \mathrm{mL}$ & 101 & $\mathrm{n} / \mathrm{a}$ & $<75.0$ & $\mathrm{n} / \mathrm{a}$ & $\mathrm{n} / \mathrm{a}$ & $\mathrm{n} / \mathrm{a}$ & $\mathrm{n} / \mathrm{a}$ & 75.0 & \\
\hline S11T011065 & Cobalt & $\mathrm{ug} / \mathrm{mL}$ & 101 & $\mathrm{n} / \mathrm{a}$ & $<25.0$ & $\mathrm{n} / \mathrm{a}$ & $\mathrm{n} / \mathrm{a}$ & $\mathrm{n} / \mathrm{a}$ & $\mathrm{n} / \mathrm{a}$ & 25.0 & \\
\hline S11T011065 & Chromium & $\mathrm{ug} / \mathrm{mL}$ & 101 & $<5.00 \mathrm{E}-03$ & $1.11 \mathrm{E}+03$ & $\mathrm{n} / \mathrm{a}$ & $\mathrm{n} / \mathrm{a}$ & $\mathrm{n} / \mathrm{a}$ & $\mathrm{n} / \mathrm{a}$ & 12.5 & \\
\hline S11T011065 & Copper & $\mathrm{ug} / \mathrm{mL}$ & 102 & $\mathrm{n} / \mathrm{a}$ & $<12.5$ & $\mathrm{n} / \mathrm{a}$ & $\mathrm{n} / \mathrm{a}$ & $\mathrm{n} / \mathrm{a}$ & $\mathrm{n} / \mathrm{a}$ & 12.5 & \\
\hline S11T011065 & Europium & $\mathrm{ug} / \mathrm{mL}$ & 95.4 & $\mathrm{n} / \mathrm{a}$ & $<12.5$ & $\mathrm{n} / \mathrm{a}$ & $\mathrm{n} / \mathrm{a}$ & $\mathrm{n} / \mathrm{a}$ & $\mathrm{n} / \mathrm{a}$ & 12.5 & \\
\hline S11T011065 & Iron & $\mathrm{ug} / \mathrm{mL}$ & 101 & $\mathrm{n} / \mathrm{a}$ & $<12.5$ & $\mathrm{n} / \mathrm{a}$ & $\mathrm{n} / \mathrm{a}$ & $\mathrm{n} / \mathrm{a}$ & $\mathrm{n} / \mathrm{a}$ & 12.5 & \\
\hline S11T011065 & Potassium & $\mathrm{ug} / \mathrm{mL}$ & 92.3 & $<0.500$ & $2.85 \mathrm{E}+03$ & $\mathrm{n} / \mathrm{a}$ & $\mathrm{n} / \mathrm{a}$ & $\mathrm{n} / \mathrm{a}$ & $\mathrm{n} / \mathrm{a}$ & $1.25 \mathrm{E}+03$ & $\mathrm{~J}$ \\
\hline S11T011065 & Lanthanum & $\mathrm{ug} / \mathrm{mL}$ & 99.5 & $\mathrm{n} / \mathrm{a}$ & $<7.50$ & $\mathrm{n} / \mathrm{a}$ & $\mathrm{n} / \mathrm{a}$ & $\mathrm{n} / \mathrm{a}$ & $\mathrm{n} / \mathrm{a}$ & 7.50 & \\
\hline
\end{tabular}


Table D-5. Centrifuged Liquid from Sample CON 4. (2 sheets)

Sample Number(s): S11T011065 (Test Sample CON 4)

Sample Group: 20111225

\begin{tabular}{|c|c|c|c|c|c|c|c|c|c|c|c|}
\hline Sample \# & Analyte & Unit & $\begin{array}{c}\text { Std } \\
\% \text {-Rec }\end{array}$ & Blank & Result & Duplicate & Average & RPD & $\begin{array}{c}\text { Spk } \\
\text { \%-Rec }\end{array}$ & $\begin{array}{c}\text { Det } \\
\text { Limit }\end{array}$ & $\begin{array}{l}\text { Qual } \\
\text { Flags }\end{array}$ \\
\hline S11T011065 & Lithium & $\mathrm{ug} / \mathrm{mL}$ & 109 & $\mathrm{n} / \mathrm{a}$ & $<7.50$ & $\mathrm{n} / \mathrm{a}$ & $\mathrm{n} / \mathrm{a}$ & $\mathrm{n} / \mathrm{a}$ & $\mathrm{n} / \mathrm{a}$ & 7.50 & \\
\hline S11T011065 & Magnesium & $\mathrm{ug} / \mathrm{mL}$ & 102 & $\mathrm{n} / \mathrm{a}$ & $<125$ & $\mathrm{n} / \mathrm{a}$ & $\mathrm{n} / \mathrm{a}$ & $\mathrm{n} / \mathrm{a}$ & $n / a$ & 125 & \\
\hline S11T011065 & Manganese & $\mathrm{ug} / \mathrm{mL}$ & 100 & $\mathrm{n} / \mathrm{a}$ & $<7.50$ & $\mathrm{n} / \mathrm{a}$ & $\mathrm{n} / \mathrm{a}$ & $\mathrm{n} / \mathrm{a}$ & $n / a$ & 7.50 & \\
\hline S11T011065 & Molybdenum & $\mathrm{ug} / \mathrm{mL}$ & 98.8 & $\mathrm{n} / \mathrm{a}$ & 54.1 & $\mathrm{n} / \mathrm{a}$ & $\mathrm{n} / \mathrm{a}$ & $\mathrm{n} / \mathrm{a}$ & $\mathrm{n} / \mathrm{a}$ & 50.0 & \\
\hline S11T011065 & Sodium & $\mathrm{ug} / \mathrm{mL}$ & 106 & $<0.100$ & $1.87 \mathrm{E}+05$ & $\mathrm{n} / \mathrm{a}$ & $\mathrm{n} / \mathrm{a}$ & $\mathrm{n} / \mathrm{a}$ & $\mathrm{n} / \mathrm{a}$ & 250 & \\
\hline S11T011065 & Neodymium & $\mathrm{ug} / \mathrm{mL}$ & 100 & $\mathrm{n} / \mathrm{a}$ & $<25.0$ & $\mathrm{n} / \mathrm{a}$ & $\mathrm{n} / \mathrm{a}$ & $\mathrm{n} / \mathrm{a}$ & $\mathrm{n} / \mathrm{a}$ & 25.0 & \\
\hline S11T011065 & Nickel & $\mathrm{ug} / \mathrm{mL}$ & 101 & $\mathrm{n} / \mathrm{a}$ & $<50.0$ & $\mathrm{n} / \mathrm{a}$ & $\mathrm{n} / \mathrm{a}$ & $\mathrm{n} / \mathrm{a}$ & $\mathrm{n} / \mathrm{a}$ & 50.0 & \\
\hline S11T011065 & Phosphorus & $\mathrm{ug} / \mathrm{mL}$ & 102 & $<0.0500$ & 472 & $\mathrm{n} / \mathrm{a}$ & $\mathrm{n} / \mathrm{a}$ & $\mathrm{n} / \mathrm{a}$ & $\mathrm{n} / \mathrm{a}$ & 125 & $\mathrm{~J}$ \\
\hline S11T011065 & Lead & $\mathrm{ug} / \mathrm{mL}$ & 104 & $\mathrm{n} / \mathrm{a}$ & $<125$ & $\mathrm{n} / \mathrm{a}$ & $\mathrm{n} / \mathrm{a}$ & $\mathrm{n} / \mathrm{a}$ & $\mathrm{n} / \mathrm{a}$ & 125 & \\
\hline S11T011065 & Sulfur & $\mathrm{ug} / \mathrm{mL}$ & 98.4 & $<0.100$ & $5.79 \mathrm{E}+03$ & $\mathrm{n} / \mathrm{a}$ & $\mathrm{n} / \mathrm{a}$ & $\mathrm{n} / \mathrm{a}$ & $\mathrm{n} / \mathrm{a}$ & 250 & \\
\hline S11T011065 & Antimony & $\mathrm{ug} / \mathrm{mL}$ & 94.6 & $\mathrm{n} / \mathrm{a}$ & $<125$ & $\mathrm{n} / \mathrm{a}$ & $\mathrm{n} / \mathrm{a}$ & $\mathrm{n} / \mathrm{a}$ & $\mathrm{n} / \mathrm{a}$ & 125 & \\
\hline S11T011065 & Selenium & $\mathrm{ug} / \mathrm{mL}$ & 104 & $\mathrm{n} / \mathrm{a}$ & $<250$ & $\mathrm{n} / \mathrm{a}$ & $\mathrm{n} / \mathrm{a}$ & $\mathrm{n} / \mathrm{a}$ & $\mathrm{n} / \mathrm{a}$ & 250 & \\
\hline S11T011065 & Silicon & $\mathrm{ug} / \mathrm{mL}$ & 94.7 & $<0.0300$ & 183 & $\mathrm{n} / \mathrm{a}$ & $\mathrm{n} / \mathrm{a}$ & $\mathrm{n} / \mathrm{a}$ & $\mathrm{n} / \mathrm{a}$ & 75.0 & $\mathrm{~J}$ \\
\hline S11T011065 & Samarium & $\mathrm{ug} / \mathrm{mL}$ & 103 & $\mathrm{n} / \mathrm{a}$ & $<125$ & $\mathrm{n} / \mathrm{a}$ & $\mathrm{n} / \mathrm{a}$ & $\mathrm{n} / \mathrm{a}$ & $\mathrm{n} / \mathrm{a}$ & 125 & \\
\hline S11T011065 & Strontium & $\mathrm{ug} / \mathrm{mL}$ & 101 & $\mathrm{n} / \mathrm{a}$ & $<7.50$ & $\mathrm{n} / \mathrm{a}$ & $\mathrm{n} / \mathrm{a}$ & $\mathrm{n} / \mathrm{a}$ & $\mathrm{n} / \mathrm{a}$ & 7.50 & \\
\hline S11T011065 & Thorium & $\mathrm{ug} / \mathrm{mL}$ & 97.5 & $\mathrm{n} / \mathrm{a}$ & $<125$ & $\mathrm{n} / \mathrm{a}$ & $\mathrm{n} / \mathrm{a}$ & $\mathrm{n} / \mathrm{a}$ & $\mathrm{n} / \mathrm{a}$ & 125 & \\
\hline S11T011065 & Titanium & $\mathrm{ug} / \mathrm{mL}$ & 97.3 & $\mathrm{n} / \mathrm{a}$ & $<12.5$ & $\mathrm{n} / \mathrm{a}$ & $\mathrm{n} / \mathrm{a}$ & $\mathrm{n} / \mathrm{a}$ & $\mathrm{n} / \mathrm{a}$ & 12.5 & \\
\hline S11T011065 & Thallium & $\mathrm{ug} / \mathrm{mL}$ & 96.2 & $\mathrm{n} / \mathrm{a}$ & $<250$ & $\mathrm{n} / \mathrm{a}$ & $\mathrm{n} / \mathrm{a}$ & $\mathrm{n} / \mathrm{a}$ & $\mathrm{n} / \mathrm{a}$ & 250 & \\
\hline S11T011065 & Uranium & $\mathrm{ug} / \mathrm{mL}$ & 101 & $\mathrm{n} / \mathrm{a}$ & $<250$ & $\mathrm{n} / \mathrm{a}$ & $\mathrm{n} / \mathrm{a}$ & $\mathrm{n} / \mathrm{a}$ & $\mathrm{n} / \mathrm{a}$ & 250 & \\
\hline S11T011065 & Vanadium & $\mathrm{ug} / \mathrm{mL}$ & 101 & $\mathrm{n} / \mathrm{a}$ & $<12.5$ & $\mathrm{n} / \mathrm{a}$ & $\mathrm{n} / \mathrm{a}$ & $\mathrm{n} / \mathrm{a}$ & $\mathrm{n} / \mathrm{a}$ & 12.5 & \\
\hline $\mathrm{S} 11 \mathrm{~T} 011065$ & Yttrium & $\mathrm{ug} / \mathrm{mL}$ & 94.7 & $\mathrm{n} / \mathrm{a}$ & $<5.00$ & $\mathrm{n} / \mathrm{a}$ & $\mathrm{n} / \mathrm{a}$ & $\mathrm{n} / \mathrm{a}$ & $\mathrm{n} / \mathrm{a}$ & 5.00 & \\
\hline S11T011065 & Zinc & $\mathrm{ug} / \mathrm{mL}$ & 99.9 & $\mathrm{n} / \mathrm{a}$ & $<12.5$ & $\mathrm{n} / \mathrm{a}$ & $\mathrm{n} / \mathrm{a}$ & $\mathrm{n} / \mathrm{a}$ & $\mathrm{n} / \mathrm{a}$ & 12.5 & \\
\hline S11T011065 & Zirconium & $\mathrm{ug} / \mathrm{mL}$ & 98.9 & $\mathrm{n} / \mathrm{a}$ & $<12.5$ & $\mathrm{n} / \mathrm{a}$ & $\mathrm{n} / \mathrm{a}$ & $\mathrm{n} / \mathrm{a}$ & $\mathrm{n} / \mathrm{a}$ & 12.5 & \\
\hline S11T011065 & Hydroxide & $\mathrm{ug} / \mathrm{mL}$ & 105 & $<41.7$ & $1.9 \mathrm{E}+04$ & $\mathrm{n} / \mathrm{a}$ & $\mathrm{n} / \mathrm{a}$ & $\mathrm{n} / \mathrm{a}$ & $\mathrm{n} / \mathrm{a}$ & 550 & \\
\hline S11T011065 & Specific gravity & unitless & 100.5 & $\mathrm{n} / \mathrm{a}$ & 1.332 & $\mathrm{n} / \mathrm{a}$ & $\mathrm{n} / \mathrm{a}$ & $\mathrm{n} / \mathrm{a}$ & $\mathrm{n} / \mathrm{a}$ & $1.00 \mathrm{E}-03$ & \\
\hline $\mathrm{S} 11 \mathrm{~T} 011065$ & Total organic carbon & $\mathrm{ug} / \mathrm{mL}$ & 97.9 & $<20.0$ & $1.15 \mathrm{E}+03$ & $\mathrm{n} / \mathrm{a}$ & $\mathrm{n} / \mathrm{a}$ & $\mathrm{n} / \mathrm{a}$ & $\mathrm{n} / \mathrm{a}$ & 200 & $\mathrm{~J}$ \\
\hline S11T011065 & Total inorganic carbon & $\mathrm{ug} / \mathrm{mL}$ & 80.0 & $<7.00$ & $1.03 \mathrm{E}+04$ & $\mathrm{n} / \mathrm{a}$ & $\mathrm{n} / \mathrm{a}$ & $\mathrm{n} / \mathrm{a}$ & $\mathrm{n} / \mathrm{a}$ & 7.00 & \\
\hline
\end{tabular}


Table D-6. Centrifuged Liquid from Sample CON 5. (2 sheets)

Sample Number(s): S11T011066 (Test Sample CON 5)

Sample Group: 20111225

\begin{tabular}{|c|c|c|c|c|c|c|c|c|c|c|c|}
\hline Sample \# & Analyte & Unit & $\begin{array}{c}\text { Std } \\
\%-\operatorname{Rec}\end{array}$ & Blank & Result & Duplicate & Average & RPD & $\begin{array}{c}\text { Spk } \\
\text { \%-Rec }\end{array}$ & $\begin{array}{c}\text { Det } \\
\text { Limit }\end{array}$ & $\begin{array}{l}\text { Qual } \\
\text { Flags }\end{array}$ \\
\hline S11T011066 & Fluoride & $\mathrm{ug} / \mathrm{mL}$ & 103 & $<1.61 \mathrm{E}-03$ & 73.1 & $\mathrm{n} / \mathrm{a}$ & $\mathrm{n} / \mathrm{a}$ & $\mathrm{n} / \mathrm{a}$ & $\mathrm{n} / \mathrm{a}$ & 1.61 & \\
\hline S11T011066 & Glycolate & $\mathrm{ug} / \mathrm{mL}$ & 101 & $<9.37 \mathrm{E}-03$ & 354 & $\mathrm{n} / \mathrm{a}$ & $\mathrm{n} / \mathrm{a}$ & $\mathrm{n} / \mathrm{a}$ & $\mathrm{n} / \mathrm{a}$ & 9.37 & \\
\hline S11T011066 & Acetate & $\mathrm{ug} / \mathrm{mL}$ & 101 & $<6.04 \mathrm{E}-03$ & 393 & $\mathrm{n} / \mathrm{a}$ & $\mathrm{n} / \mathrm{a}$ & $\mathrm{n} / \mathrm{a}$ & $\mathrm{n} / \mathrm{a}$ & 6.04 & \\
\hline S11T011066 & Formate & $\mathrm{ug} / \mathrm{mL}$ & 101 & $<4.67 \mathrm{E}-03$ & $1.22 \mathrm{E}+03$ & $\mathrm{n} / \mathrm{a}$ & $\mathrm{n} / \mathrm{a}$ & $\mathrm{n} / \mathrm{a}$ & $\mathrm{n} / \mathrm{a}$ & 4.67 & \\
\hline S11T011066 & Chloride & $\mathrm{ug} / \mathrm{mL}$ & 101 & 0.0131 & $2.61 \mathrm{E}+03$ & $\mathrm{n} / \mathrm{a}$ & $\mathrm{n} / \mathrm{a}$ & $\mathrm{n} / \mathrm{a}$ & $\mathrm{n} / \mathrm{a}$ & 9.98 & \\
\hline S11T011066 & Nitrite & $\mathrm{ug} / \mathrm{mL}$ & 101 & $<0.0192$ & $5.72 \mathrm{E}+04$ & $\mathrm{n} / \mathrm{a}$ & $\mathrm{n} / \mathrm{a}$ & $\mathrm{n} / \mathrm{a}$ & $\mathrm{n} / \mathrm{a}$ & 96.0 & \\
\hline S11T011066 & Sulfate & $\mathrm{ug} / \mathrm{mL}$ & 102 & $<0.0187$ & $1.43 \mathrm{E}+04$ & $\mathrm{n} / \mathrm{a}$ & $\mathrm{n} / \mathrm{a}$ & $\mathrm{n} / \mathrm{a}$ & $\mathrm{n} / \mathrm{a}$ & 18.7 & \\
\hline S11T011066 & Oxalate & $\mathrm{ug} / \mathrm{mL}$ & 102 & $<0.0231$ & 300 & $\mathrm{n} / \mathrm{a}$ & $\mathrm{n} / \mathrm{a}$ & $\mathrm{n} / \mathrm{a}$ & $\mathrm{n} / \mathrm{a}$ & 23.1 & $\mathrm{~J}$ \\
\hline S11T011066 & Bromide & $\mathrm{ug} / \mathrm{mL}$ & 101 & $<0.0580$ & $<58.0$ & $\mathrm{n} / \mathrm{a}$ & $\mathrm{n} / \mathrm{a}$ & $\mathrm{n} / \mathrm{a}$ & $\mathrm{n} / \mathrm{a}$ & 58.0 & $\mathrm{U}$ \\
\hline S11T011066 & Nitrate & $\mathrm{ug} / \mathrm{mL}$ & 100 & 0.0709 & $2.24 \mathrm{E}+05$ & $\mathrm{n} / \mathrm{a}$ & $\mathrm{n} / \mathrm{a}$ & $\mathrm{n} / \mathrm{a}$ & $\mathrm{n} / \mathrm{a}$ & 208 & \\
\hline S11T011066 & Phosphate & $\mathrm{ug} / \mathrm{mL}$ & 101 & $<0.0167$ & $2.43 \mathrm{E}+03$ & $\mathrm{n} / \mathrm{a}$ & $\mathrm{n} / \mathrm{a}$ & $\mathrm{n} / \mathrm{a}$ & $\mathrm{n} / \mathrm{a}$ & 16.7 & \\
\hline S11T011066 & Silver & $\mathrm{ug} / \mathrm{mL}$ & 98.6 & $\mathrm{n} / \mathrm{a}$ & $<12.5$ & $\mathrm{n} / \mathrm{a}$ & $\mathrm{n} / \mathrm{a}$ & $\mathrm{n} / \mathrm{a}$ & $\mathrm{n} / \mathrm{a}$ & 12.5 & \\
\hline S11T011066 & Aluminum & $\mathrm{ug} / \mathrm{mL}$ & 101 & $<0.0300$ & $9.14 \mathrm{E}+03$ & $\mathrm{n} / \mathrm{a}$ & $\mathrm{n} / \mathrm{a}$ & $\mathrm{n} / \mathrm{a}$ & $\mathrm{n} / \mathrm{a}$ & 75.0 & \\
\hline S11T011066 & Arsenic & $\mathrm{ug} / \mathrm{mL}$ & 100 & $\mathrm{n} / \mathrm{a}$ & $<125$ & $\mathrm{n} / \mathrm{a}$ & $\mathrm{n} / \mathrm{a}$ & $\mathrm{n} / \mathrm{a}$ & $\mathrm{n} / \mathrm{a}$ & 125 & \\
\hline S11T011066 & \begin{tabular}{|l|} 
Boron \\
\end{tabular} & $\mathrm{ug} / \mathrm{mL}$ & 99.3 & $\mathrm{n} / \mathrm{a}$ & $<75.0$ & $\mathrm{n} / \mathrm{a}$ & $\mathrm{n} / \mathrm{a}$ & $\mathrm{n} / \mathrm{a}$ & $\mathrm{n} / \mathrm{a}$ & 75.0 & \\
\hline S11T011066 & Barium & $\mathrm{ug} / \mathrm{mL}$ & 101 & $\mathrm{n} / \mathrm{a}$ & $<7.50$ & $\mathrm{n} / \mathrm{a}$ & $\mathrm{n} / \mathrm{a}$ & $\mathrm{n} / \mathrm{a}$ & $\mathrm{n} / \mathrm{a}$ & 7.50 & \\
\hline S11T011066 & Beryllium & $\mathrm{ug} / \mathrm{mL}$ & 98.9 & $\mathrm{n} / \mathrm{a}$ & $<2.50$ & $\mathrm{n} / \mathrm{a}$ & $\mathrm{n} / \mathrm{a}$ & $\mathrm{n} / \mathrm{a}$ & $\mathrm{n} / \mathrm{a}$ & 2.50 & \\
\hline S11T011066 & Bismuth & $\mathrm{ug} / \mathrm{mL}$ & 100 & $\mathrm{n} / \mathrm{a}$ & $<250$ & $\mathrm{n} / \mathrm{a}$ & $\mathrm{n} / \mathrm{a}$ & $\mathrm{n} / \mathrm{a}$ & $\mathrm{n} / \mathrm{a}$ & 250 & \\
\hline S11T011066 & Calcium & $\mathrm{ug} / \mathrm{mL}$ & 101 & $<0.0500$ & $<125$ & $\mathrm{n} / \mathrm{a}$ & $\mathrm{n} / \mathrm{a}$ & $\mathrm{n} / \mathrm{a}$ & $\mathrm{n} / \mathrm{a}$ & 125 & $\mathrm{U}$ \\
\hline S11T011066 & Cadmium & $\mathrm{ug} / \mathrm{mL}$ & 102 & $\mathrm{n} / \mathrm{a}$ & $<12.5$ & $\mathrm{n} / \mathrm{a}$ & $\mathrm{n} / \mathrm{a}$ & $\mathrm{n} / \mathrm{a}$ & $\mathrm{n} / \mathrm{a}$ & 12.5 & \\
\hline S11T011066 & Cerium & $\mathrm{ug} / \mathrm{mL}$ & 101 & $\mathrm{n} / \mathrm{a}$ & $<75.0$ & $\mathrm{n} / \mathrm{a}$ & $\mathrm{n} / \mathrm{a}$ & $\mathrm{n} / \mathrm{a}$ & $\mathrm{n} / \mathrm{a}$ & 75.0 & \\
\hline S11T011066 & Cobalt & $\mathrm{ug} / \mathrm{mL}$ & 101 & $\mathrm{n} / \mathrm{a}$ & $<25.0$ & $\mathrm{n} / \mathrm{a}$ & $\mathrm{n} / \mathrm{a}$ & $n / a$ & $\mathrm{n} / \mathrm{a}$ & 25.0 & \\
\hline S11T011066 & Chromium & $\mathrm{ug} / \mathrm{mL}$ & 101 & $<5.00 \mathrm{E}-03$ & $1.21 \mathrm{E}+03$ & $\mathrm{n} / \mathrm{a}$ & $\mathrm{n} / \mathrm{a}$ & $\mathrm{n} / \mathrm{a}$ & $\mathrm{n} / \mathrm{a}$ & 12.5 & \\
\hline S11T011066 & Copper & $\mathrm{ug} / \mathrm{mL}$ & 102 & $\mathrm{n} / \mathrm{a}$ & $<12.5$ & $\mathrm{n} / \mathrm{a}$ & $\mathrm{n} / \mathrm{a}$ & $\mathrm{n} / \mathrm{a}$ & $n / a$ & 12.5 & \\
\hline S11T011066 & Europium & $\mathrm{ug} / \mathrm{mL}$ & 95.4 & $\mathrm{n} / \mathrm{a}$ & $<12.5$ & $\mathrm{n} / \mathrm{a}$ & $\mathrm{n} / \mathrm{a}$ & $\mathrm{n} / \mathrm{a}$ & $\mathrm{n} / \mathrm{a}$ & 12.5 & \\
\hline S11T011066 & Iron & $\mathrm{ug} / \mathrm{mL}$ & 101 & $\mathrm{n} / \mathrm{a}$ & $<12.5$ & $\mathrm{n} / \mathrm{a}$ & $\mathrm{n} / \mathrm{a}$ & $\mathrm{n} / \mathrm{a}$ & $\mathrm{n} / \mathrm{a}$ & 12.5 & \\
\hline S11T011066 & Potassium & $\mathrm{ug} / \mathrm{mL}$ & 92.3 & $<0.500$ & $2.81 \mathrm{E}+03$ & $\mathrm{n} / \mathrm{a}$ & $\mathrm{n} / \mathrm{a}$ & $\mathrm{n} / \mathrm{a}$ & $\mathrm{n} / \mathrm{a}$ & $1.25 \mathrm{E}+03$ & $\mathrm{~J}$ \\
\hline S11T011066 & Lanthanum & $\mathrm{ug} / \mathrm{mL}$ & 99.5 & $\mathrm{n} / \mathrm{a}$ & $<7.50$ & $\mathrm{n} / \mathrm{a}$ & $\mathrm{n} / \mathrm{a}$ & $\mathrm{n} / \mathrm{a}$ & $\mathrm{n} / \mathrm{a}$ & 7.50 & \\
\hline
\end{tabular}


Table D-6. Centrifuged Liquid from Sample CON 5. (2 sheets)

Sample Number(s): S11T011066 (Test Sample CON 5)

Sample Group: 20111225

\begin{tabular}{|c|c|c|c|c|c|c|c|c|c|c|c|}
\hline Sample \# & Analyte & Unit & $\begin{array}{c}\text { Std } \\
\%-\operatorname{Rec}\end{array}$ & Blank & Result & Duplicate & Average & RPD & $\begin{array}{c}\text { Spk } \\
\text { \%-Rec }\end{array}$ & $\begin{array}{c}\text { Det } \\
\text { Limit }\end{array}$ & $\begin{array}{l}\text { Qual } \\
\text { Flags }\end{array}$ \\
\hline S11T011066 & Lithium & $\mathrm{ug} / \mathrm{mL}$ & 109 & $\mathrm{n} / \mathrm{a}$ & $<7.50$ & $\mathrm{n} / \mathrm{a}$ & $\mathrm{n} / \mathrm{a}$ & $\mathrm{n} / \mathrm{a}$ & $\mathrm{n} / \mathrm{a}$ & 7.50 & \\
\hline S11T011066 & Magnesium & $\mathrm{ug} / \mathrm{mL}$ & 102 & $\mathrm{n} / \mathrm{a}$ & $<125$ & $\mathrm{n} / \mathrm{a}$ & $\mathrm{n} / \mathrm{a}$ & $\mathrm{n} / \mathrm{a}$ & $\mathrm{n} / \mathrm{a}$ & 125 & \\
\hline S11T011066 & Manganese & $\mathrm{ug} / \mathrm{mL}$ & 100 & $\mathrm{n} / \mathrm{a}$ & $<7.50$ & $\mathrm{n} / \mathrm{a}$ & $\mathrm{n} / \mathrm{a}$ & $\mathrm{n} / \mathrm{a}$ & $\mathrm{n} / \mathrm{a}$ & 7.50 & \\
\hline S11T011066 & Molybdenum & $\mathrm{ug} / \mathrm{mL}$ & 98.8 & $\mathrm{n} / \mathrm{a}$ & 70.6 & $\mathrm{n} / \mathrm{a}$ & $\mathrm{n} / \mathrm{a}$ & $\mathrm{n} / \mathrm{a}$ & $\mathrm{n} / \mathrm{a}$ & 50.0 & \\
\hline S11T011066 & Sodium & $\mathrm{ug} / \mathrm{mL}$ & 106 & $<0.100$ & $2.06 \mathrm{E}+05$ & $\mathrm{n} / \mathrm{a}$ & $\mathrm{n} / \mathrm{a}$ & $\mathrm{n} / \mathrm{a}$ & $\mathrm{n} / \mathrm{a}$ & 250 & \\
\hline S11T011066 & Neodymium & $\mathrm{ug} / \mathrm{mL}$ & 100 & $\mathrm{n} / \mathrm{a}$ & $<25.0$ & $\mathrm{n} / \mathrm{a}$ & $\mathrm{n} / \mathrm{a}$ & $\mathrm{n} / \mathrm{a}$ & $\mathrm{n} / \mathrm{a}$ & 25.0 & \\
\hline S11T011066 & Nickel & $\mathrm{ug} / \mathrm{mL}$ & 101 & $\mathrm{n} / \mathrm{a}$ & $<50.0$ & $\mathrm{n} / \mathrm{a}$ & $\mathrm{n} / \mathrm{a}$ & $\mathrm{n} / \mathrm{a}$ & $\mathrm{n} / \mathrm{a}$ & 50.0 & \\
\hline S11T011066 & Phosphorus & $\mathrm{ug} / \mathrm{mL}$ & 102 & $<0.0500$ & 927 & $\mathrm{n} / \mathrm{a}$ & $\mathrm{n} / \mathrm{a}$ & $\mathrm{n} / \mathrm{a}$ & $\mathrm{n} / \mathrm{a}$ & 125 & $\mathrm{~J}$ \\
\hline S11T011066 & Lead & $\mathrm{ug} / \mathrm{mL}$ & 104 & $\mathrm{n} / \mathrm{a}$ & $<125$ & $\mathrm{n} / \mathrm{a}$ & $\mathrm{n} / \mathrm{a}$ & $\mathrm{n} / \mathrm{a}$ & $n / a$ & 125 & \\
\hline S11T011066 & Sulfur & $\mathrm{ug} / \mathrm{mL}$ & 98.4 & $<0.100$ & $5.50 \mathrm{E}+03$ & $\mathrm{n} / \mathrm{a}$ & $\mathrm{n} / \mathrm{a}$ & $\mathrm{n} / \mathrm{a}$ & $\mathrm{n} / \mathrm{a}$ & 250 & \\
\hline S11T011066 & Antimony & $\mathrm{ug} / \mathrm{mL}$ & 94.6 & $\mathrm{n} / \mathrm{a}$ & $<125$ & $\mathrm{n} / \mathrm{a}$ & $\mathrm{n} / \mathrm{a}$ & $\mathrm{n} / \mathrm{a}$ & $\mathrm{n} / \mathrm{a}$ & 125 & \\
\hline S11T011066 & Selenium & $\mathrm{ug} / \mathrm{mL}$ & 104 & $\mathrm{n} / \mathrm{a}$ & $<250$ & $\mathrm{n} / \mathrm{a}$ & $\mathrm{n} / \mathrm{a}$ & $\mathrm{n} / \mathrm{a}$ & $\mathrm{n} / \mathrm{a}$ & 250 & \\
\hline S11T011066 & Silicon & $\mathrm{ug} / \mathrm{mL}$ & 94.7 & $<0.0300$ & 233 & $\mathrm{n} / \mathrm{a}$ & $\mathrm{n} / \mathrm{a}$ & $\mathrm{n} / \mathrm{a}$ & $\mathrm{n} / \mathrm{a}$ & 75.0 & $\mathrm{~J}$ \\
\hline S11T011066 & Samarium & $\mathrm{ug} / \mathrm{mL}$ & 103 & $\mathrm{n} / \mathrm{a}$ & $<125$ & $\mathrm{n} / \mathrm{a}$ & $\mathrm{n} / \mathrm{a}$ & $\mathrm{n} / \mathrm{a}$ & $\mathrm{n} / \mathrm{a}$ & 125 & \\
\hline S11T011066 & Strontium & $\mathrm{ug} / \mathrm{mL}$ & 101 & $\mathrm{n} / \mathrm{a}$ & $<7.50$ & $\mathrm{n} / \mathrm{a}$ & $\mathrm{n} / \mathrm{a}$ & $\mathrm{n} / \mathrm{a}$ & $\mathrm{n} / \mathrm{a}$ & 7.50 & \\
\hline S11T011066 & Thorium & $\mathrm{ug} / \mathrm{mL}$ & 97.5 & $\mathrm{n} / \mathrm{a}$ & $<125$ & $\mathrm{n} / \mathrm{a}$ & $\mathrm{n} / \mathrm{a}$ & $\mathrm{n} / \mathrm{a}$ & $\mathrm{n} / \mathrm{a}$ & 125 & \\
\hline S11T011066 & Titanium & $\mathrm{ug} / \mathrm{mL}$ & 97.3 & $\mathrm{n} / \mathrm{a}$ & $<12.5$ & $\mathrm{n} / \mathrm{a}$ & $\mathrm{n} / \mathrm{a}$ & $\mathrm{n} / \mathrm{a}$ & $\mathrm{n} / \mathrm{a}$ & 12.5 & \\
\hline S11T011066 & Thallium & $\mathrm{ug} / \mathrm{mL}$ & 96.2 & $\mathrm{n} / \mathrm{a}$ & $<250$ & $\mathrm{n} / \mathrm{a}$ & $\mathrm{n} / \mathrm{a}$ & $\mathrm{n} / \mathrm{a}$ & $\mathrm{n} / \mathrm{a}$ & 250 & \\
\hline S11T011066 & Uranium & $\mathrm{ug} / \mathrm{mL}$ & 101 & $\mathrm{n} / \mathrm{a}$ & $<250$ & $n / a$ & $\mathrm{n} / \mathrm{a}$ & $\mathrm{n} / \mathrm{a}$ & $\mathrm{n} / \mathrm{a}$ & 250 & \\
\hline S11T011066 & Vanadium & $\mathrm{ug} / \mathrm{mL}$ & 101 & $\mathrm{n} / \mathrm{a}$ & $<12.5$ & $\mathrm{n} / \mathrm{a}$ & $\mathrm{n} / \mathrm{a}$ & $\mathrm{n} / \mathrm{a}$ & $\mathrm{n} / \mathrm{a}$ & 12.5 & \\
\hline S11T011066 & Yttrium & $\mathrm{ug} / \mathrm{mL}$ & 94.7 & $\mathrm{n} / \mathrm{a}$ & $<5.00$ & $\mathrm{n} / \mathrm{a}$ & $\mathrm{n} / \mathrm{a}$ & $\mathrm{n} / \mathrm{a}$ & $\mathrm{n} / \mathrm{a}$ & 5.00 & \\
\hline S11T011066 & Zinc & $\mathrm{ug} / \mathrm{mL}$ & 99.9 & $\mathrm{n} / \mathrm{a}$ & $<12.5$ & $\mathrm{n} / \mathrm{a}$ & $\mathrm{n} / \mathrm{a}$ & $\mathrm{n} / \mathrm{a}$ & $\mathrm{n} / \mathrm{a}$ & 12.5 & \\
\hline S11T011066 & Zirconium & $\mathrm{ug} / \mathrm{mL}$ & 98.9 & $\mathrm{n} / \mathrm{a}$ & $<12.5$ & $\mathrm{n} / \mathrm{a}$ & $\mathrm{n} / \mathrm{a}$ & $\mathrm{n} / \mathrm{a}$ & $\mathrm{n} / \mathrm{a}$ & 12.5 & \\
\hline S11T011066 & Hydroxide & $\mathrm{ug} / \mathrm{mL}$ & 105 & $<41.7$ & $2.3 \mathrm{E}+04$ & $\mathrm{n} / \mathrm{a}$ & $\mathrm{n} / \mathrm{a}$ & $\mathrm{n} / \mathrm{a}$ & $\mathrm{n} / \mathrm{a}$ & 550 & \\
\hline S11T011066 & Specific gravity & unitless & 100.5 & $\mathrm{n} / \mathrm{a}$ & 1.317 & $\mathrm{n} / \mathrm{a}$ & $\mathrm{n} / \mathrm{a}$ & $\mathrm{n} / \mathrm{a}$ & $\mathrm{n} / \mathrm{a}$ & $1.00 \mathrm{E}-03$ & \\
\hline S11T011066 & Total organic carbon & $\mathrm{ug} / \mathrm{mL}$ & 96.5 & $<20.0$ & $1.33 \mathrm{E}+03$ & $1.35 \mathrm{E}+03$ & $1.34 \mathrm{E}+03$ & 1.49 & 90.8 & 200 & $\mathrm{~J}$ \\
\hline S11T011066 & Total inorganic carbon & $\mathrm{ug} / \mathrm{mL}$ & 98.7 & $<7.00$ & $1.11 \mathrm{E}+04$ & $1.13 \mathrm{E}+04$ & $1.12 \mathrm{E}+04$ & 1.79 & 94.6 & 70.0 & \\
\hline
\end{tabular}


Table D-7. Centrifuged Liquid from Sample CON 6. (2 sheets)

Sample Number(s): S11T011067 (Test Sample CON 6)

Sample Group: 20111225

\begin{tabular}{|c|c|c|c|c|c|c|c|c|c|c|c|}
\hline Sample \# & Analyte & Unit & $\begin{array}{c}\text { Std } \\
\%-\operatorname{Rec}\end{array}$ & Blank & Result & Duplicate & Average & RPD & $\begin{array}{c}\text { Spk } \\
\text { \%-Rec }\end{array}$ & $\begin{array}{c}\text { Det } \\
\text { Limit }\end{array}$ & $\begin{array}{l}\text { Qual } \\
\text { Flags }\end{array}$ \\
\hline S11T011067 & Fluoride & $\mathrm{ug} / \mathrm{mL}$ & 103 & $<1.61 \mathrm{E}-03$ & 31.2 & $\mathrm{n} / \mathrm{a}$ & $\mathrm{n} / \mathrm{a}$ & $\mathrm{n} / \mathrm{a}$ & $\mathrm{n} / \mathrm{a}$ & 1.61 & \\
\hline S11T011067 & Glycolate & $\mathrm{ug} / \mathrm{mL}$ & 101 & $<9.37 \mathrm{E}-03$ & 397 & $\mathrm{n} / \mathrm{a}$ & $\mathrm{n} / \mathrm{a}$ & $\mathrm{n} / \mathrm{a}$ & $\mathrm{n} / \mathrm{a}$ & 9.37 & \\
\hline S11T011067 & Acetate & $\mathrm{ug} / \mathrm{mL}$ & 101 & $<6.04 \mathrm{E}-03$ & 446 & $\mathrm{n} / \mathrm{a}$ & $\mathrm{n} / \mathrm{a}$ & $\mathrm{n} / \mathrm{a}$ & $\mathrm{n} / \mathrm{a}$ & 6.04 & \\
\hline S11T011067 & Formate & $\mathrm{ug} / \mathrm{mL}$ & 101 & $<4.67 \mathrm{E}-03$ & $1.34 \mathrm{E}+03$ & $\mathrm{n} / \mathrm{a}$ & $\mathrm{n} / \mathrm{a}$ & $\mathrm{n} / \mathrm{a}$ & $\mathrm{n} / \mathrm{a}$ & 4.67 & \\
\hline S11T011067 & Chloride & $\mathrm{ug} / \mathrm{mL}$ & 101 & 0.0131 & $2.88 \mathrm{E}+03$ & $\mathrm{n} / \mathrm{a}$ & $\mathrm{n} / \mathrm{a}$ & $\mathrm{n} / \mathrm{a}$ & $\mathrm{n} / \mathrm{a}$ & 9.98 & \\
\hline S11T011067 & Nitrite & $\mathrm{ug} / \mathrm{mL}$ & 101 & $<0.0192$ & $6.31 \mathrm{E}+04$ & $\mathrm{n} / \mathrm{a}$ & $\mathrm{n} / \mathrm{a}$ & $\mathrm{n} / \mathrm{a}$ & $\mathrm{n} / \mathrm{a}$ & 96.0 & \\
\hline S11T011067 & Sulfate & $\mathrm{ug} / \mathrm{mL}$ & 102 & $<0.0187$ & $1.52 \mathrm{E}+04$ & $\mathrm{n} / \mathrm{a}$ & $\mathrm{n} / \mathrm{a}$ & $\mathrm{n} / \mathrm{a}$ & $\mathrm{n} / \mathrm{a}$ & 18.7 & \\
\hline S11T011067 & Oxalate & $\mathrm{ug} / \mathrm{mL}$ & 102 & $<0.0231$ & 251 & $\mathrm{n} / \mathrm{a}$ & $\mathrm{n} / \mathrm{a}$ & $\mathrm{n} / \mathrm{a}$ & $\mathrm{n} / \mathrm{a}$ & 23.1 & $\mathrm{~J}$ \\
\hline S11T011067 & Bromide & $\mathrm{ug} / \mathrm{mL}$ & 101 & $<0.0580$ & $<58.0$ & $\mathrm{n} / \mathrm{a}$ & $\mathrm{n} / \mathrm{a}$ & $\mathrm{n} / \mathrm{a}$ & $\mathrm{n} / \mathrm{a}$ & 58.0 & $\mathrm{U}$ \\
\hline S11T011067 & Nitrate & $\mathrm{ug} / \mathrm{mL}$ & 100 & 0.0709 & $2.16 \mathrm{E}+05$ & $\mathrm{n} / \mathrm{a}$ & $\mathrm{n} / \mathrm{a}$ & $\mathrm{n} / \mathrm{a}$ & $\mathrm{n} / \mathrm{a}$ & 208 & \\
\hline S11T011067 & Phosphate & $\mathrm{ug} / \mathrm{mL}$ & 101 & $<0.0167$ & $3.07 \mathrm{E}+03$ & $\mathrm{n} / \mathrm{a}$ & $\mathrm{n} / \mathrm{a}$ & $\mathrm{n} / \mathrm{a}$ & $\mathrm{n} / \mathrm{a}$ & 16.7 & \\
\hline S11T011067 & Silver & $\mathrm{ug} / \mathrm{mL}$ & 97.6 & $\mathrm{n} / \mathrm{a}$ & $<12.5$ & $\mathrm{n} / \mathrm{a}$ & $\mathrm{n} / \mathrm{a}$ & $\mathrm{n} / \mathrm{a}$ & $\mathrm{n} / \mathrm{a}$ & 12.5 & \\
\hline S11T011067 & \begin{tabular}{|l|} 
Aluminum \\
\end{tabular} & $\mathrm{ug} / \mathrm{mL}$ & 100 & $<0.0300$ & $1.02 \mathrm{E}+04$ & $\mathrm{n} / \mathrm{a}$ & $\mathrm{n} / \mathrm{a}$ & $\mathrm{n} / \mathrm{a}$ & $\mathrm{n} / \mathrm{a}$ & 75.0 & \\
\hline S11T011067 & Arsenic & $\mathrm{ug} / \mathrm{mL}$ & 100 & $\mathrm{n} / \mathrm{a}$ & $<125$ & $\mathrm{n} / \mathrm{a}$ & $\mathrm{n} / \mathrm{a}$ & $\mathrm{n} / \mathrm{a}$ & $\mathrm{n} / \mathrm{a}$ & 125 & \\
\hline S11T011067 & \begin{tabular}{|l|} 
Boron \\
\end{tabular} & $\mathrm{ug} / \mathrm{mL}$ & 99.2 & $\mathrm{n} / \mathrm{a}$ & $<75.0$ & $\mathrm{n} / \mathrm{a}$ & $\mathrm{n} / \mathrm{a}$ & $\mathrm{n} / \mathrm{a}$ & $\mathrm{n} / \mathrm{a}$ & 75.0 & \\
\hline S11T011067 & Barium & $\mathrm{ug} / \mathrm{mL}$ & 99.0 & $\mathrm{n} / \mathrm{a}$ & $<7.50$ & $\mathrm{n} / \mathrm{a}$ & $\mathrm{n} / \mathrm{a}$ & $\mathrm{n} / \mathrm{a}$ & $\mathrm{n} / \mathrm{a}$ & 7.50 & \\
\hline S11T011067 & Beryllium & $\mathrm{ug} / \mathrm{mL}$ & 97.5 & $\mathrm{n} / \mathrm{a}$ & $<2.50$ & $\mathrm{n} / \mathrm{a}$ & $\mathrm{n} / \mathrm{a}$ & $\mathrm{n} / \mathrm{a}$ & $\mathrm{n} / \mathrm{a}$ & 2.50 & \\
\hline S11T011067 & Bismuth & $\mathrm{ug} / \mathrm{mL}$ & 97.0 & $\mathrm{n} / \mathrm{a}$ & $<250$ & $\mathrm{n} / \mathrm{a}$ & $\mathrm{n} / \mathrm{a}$ & $\mathrm{n} / \mathrm{a}$ & $\mathrm{n} / \mathrm{a}$ & 250 & \\
\hline S11T011067 & Calcium & $\mathrm{ug} / \mathrm{mL}$ & 110 & $<0.0500$ & $<125$ & $\mathrm{n} / \mathrm{a}$ & $\mathrm{n} / \mathrm{a}$ & $\mathrm{n} / \mathrm{a}$ & $\mathrm{n} / \mathrm{a}$ & 125 & $\mathrm{U}$ \\
\hline S11T011067 & Cadmium & $\mathrm{ug} / \mathrm{mL}$ & 98.1 & $\mathrm{n} / \mathrm{a}$ & $<12.5$ & $\mathrm{n} / \mathrm{a}$ & $\mathrm{n} / \mathrm{a}$ & $\mathrm{n} / \mathrm{a}$ & $\mathrm{n} / \mathrm{a}$ & 12.5 & \\
\hline S11T011067 & Cerium & $\mathrm{ug} / \mathrm{mL}$ & 99.4 & $\mathrm{n} / \mathrm{a}$ & $<75.0$ & $\mathrm{n} / \mathrm{a}$ & $\mathrm{n} / \mathrm{a}$ & $\mathrm{n} / \mathrm{a}$ & $\mathrm{n} / \mathrm{a}$ & 75.0 & \\
\hline S11T011067 & Cobalt & $\mathrm{ug} / \mathrm{mL}$ & 98.1 & $\mathrm{n} / \mathrm{a}$ & $<25.0$ & $\mathrm{n} / \mathrm{a}$ & $\mathrm{n} / \mathrm{a}$ & $n / a$ & $\mathrm{n} / \mathrm{a}$ & 25.0 & \\
\hline S11T011067 & Chromium & $\mathrm{ug} / \mathrm{mL}$ & 98.1 & $<5.00 \mathrm{E}-03$ & $1.32 \mathrm{E}+03$ & $\mathrm{n} / \mathrm{a}$ & $\mathrm{n} / \mathrm{a}$ & $\mathrm{n} / \mathrm{a}$ & $\mathrm{n} / \mathrm{a}$ & 12.5 & \\
\hline S11T011067 & Copper & $\mathrm{ug} / \mathrm{mL}$ & 99.8 & $\mathrm{n} / \mathrm{a}$ & $<12.5$ & $\mathrm{n} / \mathrm{a}$ & $\mathrm{n} / \mathrm{a}$ & $\mathrm{n} / \mathrm{a}$ & $n / a$ & 12.5 & \\
\hline S11T011067 & Europium & $\mathrm{ug} / \mathrm{mL}$ & 94.3 & $\mathrm{n} / \mathrm{a}$ & $<12.5$ & $\mathrm{n} / \mathrm{a}$ & $\mathrm{n} / \mathrm{a}$ & $\mathrm{n} / \mathrm{a}$ & $\mathrm{n} / \mathrm{a}$ & 12.5 & \\
\hline S11T011067 & Iron & $\mathrm{ug} / \mathrm{mL}$ & 99.6 & $\mathrm{n} / \mathrm{a}$ & $<12.5$ & $\mathrm{n} / \mathrm{a}$ & $\mathrm{n} / \mathrm{a}$ & $\mathrm{n} / \mathrm{a}$ & $\mathrm{n} / \mathrm{a}$ & 12.5 & \\
\hline S11T011067 & \begin{tabular}{|l|} 
Potassium \\
\end{tabular} & $\mathrm{ug} / \mathrm{mL}$ & 91.2 & $<0.500$ & $3.49 \mathrm{E}+03$ & $\mathrm{n} / \mathrm{a}$ & $\mathrm{n} / \mathrm{a}$ & $\mathrm{n} / \mathrm{a}$ & $\mathrm{n} / \mathrm{a}$ & $1.25 \mathrm{E}+03$ & $\mathrm{~J}$ \\
\hline S11T011067 & Lanthanum & $\mathrm{ug} / \mathrm{mL}$ & 99.2 & $\mathrm{n} / \mathrm{a}$ & $<7.50$ & $\mathrm{n} / \mathrm{a}$ & $\mathrm{n} / \mathrm{a}$ & $\mathrm{n} / \mathrm{a}$ & $\mathrm{n} / \mathrm{a}$ & 7.50 & \\
\hline
\end{tabular}


Table D-7. Centrifuged Liquid from Sample CON 6. (2 sheets)

Sample Number(s): S11T011067 (Test Sample CON 6)

Sample Group: 20111225

\begin{tabular}{|c|c|c|c|c|c|c|c|c|c|c|c|}
\hline Sample \# & Analyte & Unit & $\begin{array}{c}\text { Std } \\
\text { \%-Rec }\end{array}$ & Blank & Result & Duplicate & Average & RPD & $\begin{array}{c}\text { Spk } \\
\text { \%-Rec }\end{array}$ & $\begin{array}{c}\text { Det } \\
\text { Limit }\end{array}$ & $\begin{array}{l}\text { Qual } \\
\text { Flags }\end{array}$ \\
\hline S11T011067 & Lithium & $\mathrm{ug} / \mathrm{mL}$ & 107 & $\mathrm{n} / \mathrm{a}$ & $<7.50$ & $\mathrm{n} / \mathrm{a}$ & $\mathrm{n} / \mathrm{a}$ & $\mathrm{n} / \mathrm{a}$ & $\mathrm{n} / \mathrm{a}$ & 7.50 & \\
\hline S11T011067 & Magnesium & $\mathrm{ug} / \mathrm{mL}$ & 99.5 & $\mathrm{n} / \mathrm{a}$ & $<125$ & $\mathrm{n} / \mathrm{a}$ & $\mathrm{n} / \mathrm{a}$ & $\mathrm{n} / \mathrm{a}$ & $\mathrm{n} / \mathrm{a}$ & 125 & \\
\hline S11T011067 & Manganese & $\mathrm{ug} / \mathrm{mL}$ & 96.4 & $\mathrm{n} / \mathrm{a}$ & $<7.50$ & $\mathrm{n} / \mathrm{a}$ & $\mathrm{n} / \mathrm{a}$ & $\mathrm{n} / \mathrm{a}$ & $\mathrm{n} / \mathrm{a}$ & 7.50 & \\
\hline S11T011067 & Molybdenum & $\mathrm{ug} / \mathrm{mL}$ & 98.4 & $\mathrm{n} / \mathrm{a}$ & 65.5 & $\mathrm{n} / \mathrm{a}$ & $\mathrm{n} / \mathrm{a}$ & $\mathrm{n} / \mathrm{a}$ & $\mathrm{n} / \mathrm{a}$ & 50.0 & \\
\hline S11T011067 & Sodium & $\mathrm{ug} / \mathrm{mL}$ & 107 & $<0.100$ & $2.20 \mathrm{E}+05$ & $\mathrm{n} / \mathrm{a}$ & $\mathrm{n} / \mathrm{a}$ & $\mathrm{n} / \mathrm{a}$ & $\mathrm{n} / \mathrm{a}$ & 250 & \\
\hline S11T011067 & Neodymium & $\mathrm{ug} / \mathrm{mL}$ & 97.4 & $\mathrm{n} / \mathrm{a}$ & $<25.0$ & $\mathrm{n} / \mathrm{a}$ & $\mathrm{n} / \mathrm{a}$ & $\mathrm{n} / \mathrm{a}$ & $\mathrm{n} / \mathrm{a}$ & 25.0 & \\
\hline S11T011067 & Nickel & $\mathrm{ug} / \mathrm{mL}$ & 97.3 & $\mathrm{n} / \mathrm{a}$ & $<50.0$ & $\mathrm{n} / \mathrm{a}$ & $\mathrm{n} / \mathrm{a}$ & $\mathrm{n} / \mathrm{a}$ & $\mathrm{n} / \mathrm{a}$ & 50.0 & \\
\hline S11T011067 & Phosphorus & $\mathrm{ug} / \mathrm{mL}$ & 99.1 & $<0.0500$ & $1.14 \mathrm{E}+03$ & $\mathrm{n} / \mathrm{a}$ & $\mathrm{n} / \mathrm{a}$ & $\mathrm{n} / \mathrm{a}$ & $\mathrm{n} / \mathrm{a}$ & 125 & $\mathrm{~J}$ \\
\hline S11T011067 & Lead & $\mathrm{ug} / \mathrm{mL}$ & 101 & $\mathrm{n} / \mathrm{a}$ & $<125$ & $\mathrm{n} / \mathrm{a}$ & $\mathrm{n} / \mathrm{a}$ & $\mathrm{n} / \mathrm{a}$ & $\mathrm{n} / \mathrm{a}$ & 125 & \\
\hline S11T011067 & Sulfur & $\mathrm{ug} / \mathrm{mL}$ & 99.2 & $<0.100$ & $5.83 \mathrm{E}+03$ & $\mathrm{n} / \mathrm{a}$ & $\mathrm{n} / \mathrm{a}$ & $\mathrm{n} / \mathrm{a}$ & $\mathrm{n} / \mathrm{a}$ & 250 & \\
\hline S11T011067 & Antimony & $\mathrm{ug} / \mathrm{mL}$ & 95.3 & $\mathrm{n} / \mathrm{a}$ & $<125$ & $\mathrm{n} / \mathrm{a}$ & $\mathrm{n} / \mathrm{a}$ & $\mathrm{n} / \mathrm{a}$ & $\mathrm{n} / \mathrm{a}$ & 125 & \\
\hline S11T011067 & Selenium & $\mathrm{ug} / \mathrm{mL}$ & 101 & $\mathrm{n} / \mathrm{a}$ & $<250$ & $\mathrm{n} / \mathrm{a}$ & $\mathrm{n} / \mathrm{a}$ & $\mathrm{n} / \mathrm{a}$ & $\mathrm{n} / \mathrm{a}$ & 250 & \\
\hline S11T011067 & Silicon & $\mathrm{ug} / \mathrm{mL}$ & 96.7 & $<0.0300$ & 141 & $\mathrm{n} / \mathrm{a}$ & $\mathrm{n} / \mathrm{a}$ & $\mathrm{n} / \mathrm{a}$ & $\mathrm{n} / \mathrm{a}$ & 75.0 & $\mathrm{~J}$ \\
\hline S11T011067 & Samarium & $\mathrm{ug} / \mathrm{mL}$ & 102 & $\mathrm{n} / \mathrm{a}$ & $<125$ & $\mathrm{n} / \mathrm{a}$ & $\mathrm{n} / \mathrm{a}$ & $\mathrm{n} / \mathrm{a}$ & $\mathrm{n} / \mathrm{a}$ & 125 & \\
\hline S11T011067 & Strontium & $\mathrm{ug} / \mathrm{mL}$ & 98.3 & $\mathrm{n} / \mathrm{a}$ & $<7.50$ & $\mathrm{n} / \mathrm{a}$ & $\mathrm{n} / \mathrm{a}$ & $\mathrm{n} / \mathrm{a}$ & $\mathrm{n} / \mathrm{a}$ & 7.50 & \\
\hline S11T011067 & Thorium & $\mathrm{ug} / \mathrm{mL}$ & 97.3 & $\mathrm{n} / \mathrm{a}$ & $<125$ & $\mathrm{n} / \mathrm{a}$ & $\mathrm{n} / \mathrm{a}$ & $\mathrm{n} / \mathrm{a}$ & $\mathrm{n} / \mathrm{a}$ & 125 & \\
\hline S11T011067 & Titanium & $\mathrm{ug} / \mathrm{mL}$ & 96.6 & $\mathrm{n} / \mathrm{a}$ & $<12.5$ & $\mathrm{n} / \mathrm{a}$ & $\mathrm{n} / \mathrm{a}$ & $\mathrm{n} / \mathrm{a}$ & $\mathrm{n} / \mathrm{a}$ & 12.5 & \\
\hline S11T011067 & Thallium & $\mathrm{ug} / \mathrm{mL}$ & 97.3 & $\mathrm{n} / \mathrm{a}$ & $<250$ & $\mathrm{n} / \mathrm{a}$ & $\mathrm{n} / \mathrm{a}$ & $\mathrm{n} / \mathrm{a}$ & $\mathrm{n} / \mathrm{a}$ & 250 & \\
\hline S11T011067 & Uranium & $\mathrm{ug} / \mathrm{mL}$ & 99.5 & $\mathrm{n} / \mathrm{a}$ & $<250$ & $\mathrm{n} / \mathrm{a}$ & $\mathrm{n} / \mathrm{a}$ & $\mathrm{n} / \mathrm{a}$ & $\mathrm{n} / \mathrm{a}$ & 250 & \\
\hline S11T011067 & Vanadium & $\mathrm{ug} / \mathrm{mL}$ & 98.8 & $\mathrm{n} / \mathrm{a}$ & $<12.5$ & $\mathrm{n} / \mathrm{a}$ & $\mathrm{n} / \mathrm{a}$ & $\mathrm{n} / \mathrm{a}$ & $\mathrm{n} / \mathrm{a}$ & 12.5 & \\
\hline S11T011067 & Yttrium & $\mathrm{ug} / \mathrm{mL}$ & 94.7 & $\mathrm{n} / \mathrm{a}$ & $<5.00$ & $\mathrm{n} / \mathrm{a}$ & $\mathrm{n} / \mathrm{a}$ & $\mathrm{n} / \mathrm{a}$ & $\mathrm{n} / \mathrm{a}$ & 5.00 & \\
\hline S11T011067 & Zinc & $\mathrm{ug} / \mathrm{mL}$ & 96.6 & $\mathrm{n} / \mathrm{a}$ & $<12.5$ & $\mathrm{n} / \mathrm{a}$ & $\mathrm{n} / \mathrm{a}$ & $\mathrm{n} / \mathrm{a}$ & $\mathrm{n} / \mathrm{a}$ & 12.5 & \\
\hline S11T011067 & Zirconium & $\mathrm{ug} / \mathrm{mL}$ & 98.7 & $\mathrm{n} / \mathrm{a}$ & $<12.5$ & $\mathrm{n} / \mathrm{a}$ & $\mathrm{n} / \mathrm{a}$ & $\mathrm{n} / \mathrm{a}$ & $\mathrm{n} / \mathrm{a}$ & 12.5 & \\
\hline S11T011067 & Hydroxide & $\mathrm{ug} / \mathrm{mL}$ & 105 & $<41.7$ & $2.0 \mathrm{E}+04$ & $\mathrm{n} / \mathrm{a}$ & $\mathrm{n} / \mathrm{a}$ & $\mathrm{n} / \mathrm{a}$ & $\mathrm{n} / \mathrm{a}$ & 550 & \\
\hline S11T011067 & Specific gravity & unitless & 100.5 & $\mathrm{n} / \mathrm{a}$ & 1.381 & $\mathrm{n} / \mathrm{a}$ & $\mathrm{n} / \mathrm{a}$ & $\mathrm{n} / \mathrm{a}$ & $\mathrm{n} / \mathrm{a}$ & $1.00 \mathrm{E}-03$ & \\
\hline $\mathrm{S} 11 \mathrm{~T} 011067$ & Total organic carbon & $\mathrm{ug} / \mathrm{mL}$ & 96.5 & $<20.0$ & $1.64 \mathrm{E}+03$ & $\mathrm{n} / \mathrm{a}$ & $\mathrm{n} / \mathrm{a}$ & $\mathrm{n} / \mathrm{a}$ & $\mathrm{n} / \mathrm{a}$ & 200 & $\mathrm{~J}$ \\
\hline S11T011067 & Total inorganic carbon & $\mathrm{ug} / \mathrm{mL}$ & 98.7 & $<7.00$ & $1.24 \mathrm{E}+04$ & $\mathrm{n} / \mathrm{a}$ & $\mathrm{n} / \mathrm{a}$ & $\mathrm{n} / \mathrm{a}$ & $\mathrm{n} / \mathrm{a}$ & 70.0 & \\
\hline
\end{tabular}


Table D-8. Centrifuged Liquid from Sample CON 7. (2 sheets)

Sample Number(s): S11T011070 (Test Sample CON 7)

Sample Group: 20111225

\begin{tabular}{|c|c|c|c|c|c|c|c|c|c|c|c|}
\hline Sample \# & Analyte & Unit & $\begin{array}{c}\text { Std } \\
\%-\operatorname{Rec}\end{array}$ & Blank & Result & Duplicate & Average & RPD & $\begin{array}{c}\text { Spk } \\
\% \text {-Rec }\end{array}$ & $\begin{array}{c}\text { Det } \\
\text { Limit }\end{array}$ & $\begin{array}{l}\text { Qual } \\
\text { Flags }\end{array}$ \\
\hline S11T011070 & Fluoride & $\mathrm{ug} / \mathrm{mL}$ & 103 & $<1.61 \mathrm{E}-03$ & 25.2 & $\mathrm{n} / \mathrm{a}$ & $\mathrm{n} / \mathrm{a}$ & $\mathrm{n} / \mathrm{a}$ & $\mathrm{n} / \mathrm{a}$ & 1.61 & $\mathrm{~J}$ \\
\hline S11T011070 & Glycolate & $\mathrm{ug} / \mathrm{mL}$ & 101 & $<9.37 \mathrm{E}-03$ & 417 & $\mathrm{n} / \mathrm{a}$ & $\mathrm{n} / \mathrm{a}$ & $\mathrm{n} / \mathrm{a}$ & $\mathrm{n} / \mathrm{a}$ & 9.37 & \\
\hline S11T011070 & Acetate & $\mathrm{ug} / \mathrm{mL}$ & 101 & $<6.04 \mathrm{E}-03$ & 462 & $\mathrm{n} / \mathrm{a}$ & $\mathrm{n} / \mathrm{a}$ & $\mathrm{n} / \mathrm{a}$ & $\mathrm{n} / \mathrm{a}$ & 6.04 & \\
\hline S11T011070 & Formate & $\mathrm{ug} / \mathrm{mL}$ & 101 & $<4.67 \mathrm{E}-03$ & $1.40 \mathrm{E}+03$ & $\mathrm{n} / \mathrm{a}$ & $\mathrm{n} / \mathrm{a}$ & $\mathrm{n} / \mathrm{a}$ & $\mathrm{n} / \mathrm{a}$ & 4.67 & \\
\hline S11T011070 & Chloride & $\mathrm{ug} / \mathrm{mL}$ & 101 & 0.0131 & $3.02 \mathrm{E}+03$ & $\mathrm{n} / \mathrm{a}$ & $\mathrm{n} / \mathrm{a}$ & $\mathrm{n} / \mathrm{a}$ & $\mathrm{n} / \mathrm{a}$ & 9.98 & \\
\hline S11T011070 & Nitrite & $\mathrm{ug} / \mathrm{mL}$ & 101 & $<0.0192$ & $6.40 \mathrm{E}+04$ & $\mathrm{n} / \mathrm{a}$ & $\mathrm{n} / \mathrm{a}$ & $\mathrm{n} / \mathrm{a}$ & $\mathrm{n} / \mathrm{a}$ & 96.0 & \\
\hline S11T011070 & Sulfate & $\mathrm{ug} / \mathrm{mL}$ & 102 & $<0.0187$ & $1.36 \mathrm{E}+04$ & $\mathrm{n} / \mathrm{a}$ & $\mathrm{n} / \mathrm{a}$ & $\mathrm{n} / \mathrm{a}$ & $\mathrm{n} / \mathrm{a}$ & 18.7 & \\
\hline S11T011070 & Oxalate & $\mathrm{ug} / \mathrm{mL}$ & 102 & $<0.0231$ & 128 & $\mathrm{n} / \mathrm{a}$ & $\mathrm{n} / \mathrm{a}$ & $\mathrm{n} / \mathrm{a}$ & $\mathrm{n} / \mathrm{a}$ & 23.1 & $\mathrm{~J}$ \\
\hline S11T011070 & Bromide & $\mathrm{ug} / \mathrm{mL}$ & 101 & $<0.0580$ & $<58.0$ & $\mathrm{n} / \mathrm{a}$ & $\mathrm{n} / \mathrm{a}$ & $\mathrm{n} / \mathrm{a}$ & $\mathrm{n} / \mathrm{a}$ & 58.0 & $\mathrm{U}$ \\
\hline S11T011070 & Nitrate & $\mathrm{ug} / \mathrm{mL}$ & 100 & 0.0709 & $1.96 \mathrm{E}+05$ & $\mathrm{n} / \mathrm{a}$ & $\mathrm{n} / \mathrm{a}$ & $\mathrm{n} / \mathrm{a}$ & $\mathrm{n} / \mathrm{a}$ & 208 & \\
\hline S11T011070 & Phosphate & $\mathrm{ug} / \mathrm{mL}$ & 101 & $<0.0167$ & $2.07 \mathrm{E}+03$ & $\mathrm{n} / \mathrm{a}$ & $\mathrm{n} / \mathrm{a}$ & $\mathrm{n} / \mathrm{a}$ & $\mathrm{n} / \mathrm{a}$ & 16.7 & \\
\hline S11T011070 & Silver & $\mathrm{ug} / \mathrm{mL}$ & 97.6 & $\mathrm{n} / \mathrm{a}$ & $<12.5$ & $\mathrm{n} / \mathrm{a}$ & $\mathrm{n} / \mathrm{a}$ & $\mathrm{n} / \mathrm{a}$ & $\mathrm{n} / \mathrm{a}$ & 12.5 & \\
\hline S11T011070 & Aluminum & $\mathrm{ug} / \mathrm{mL}$ & 100 & $<0.0300$ & $1.16 \mathrm{E}+04$ & $\mathrm{n} / \mathrm{a}$ & $\mathrm{n} / \mathrm{a}$ & $\mathrm{n} / \mathrm{a}$ & $\mathrm{n} / \mathrm{a}$ & 75.0 & \\
\hline S11T011070 & Arsenic & $\mathrm{ug} / \mathrm{mL}$ & 100 & $\mathrm{n} / \mathrm{a}$ & $<125$ & $\mathrm{n} / \mathrm{a}$ & $\mathrm{n} / \mathrm{a}$ & $\mathrm{n} / \mathrm{a}$ & $\mathrm{n} / \mathrm{a}$ & 125 & \\
\hline $\mathrm{S} 11 \mathrm{~T} 011070$ & Boron & $\mathrm{ug} / \mathrm{mL}$ & 99.2 & $\mathrm{n} / \mathrm{a}$ & $<75.0$ & $\mathrm{n} / \mathrm{a}$ & $\mathrm{n} / \mathrm{a}$ & $\mathrm{n} / \mathrm{a}$ & $\mathrm{n} / \mathrm{a}$ & 75.0 & \\
\hline S11T011070 & Barium & $\mathrm{ug} / \mathrm{mL}$ & 99.0 & $\mathrm{n} / \mathrm{a}$ & $<7.50$ & $\mathrm{n} / \mathrm{a}$ & $\mathrm{n} / \mathrm{a}$ & $\mathrm{n} / \mathrm{a}$ & $\mathrm{n} / \mathrm{a}$ & 7.50 & \\
\hline S11T011070 & Beryllium & $\mathrm{ug} / \mathrm{mL}$ & 97.5 & $\mathrm{n} / \mathrm{a}$ & $<2.50$ & $\mathrm{n} / \mathrm{a}$ & $\mathrm{n} / \mathrm{a}$ & $\mathrm{n} / \mathrm{a}$ & $\mathrm{n} / \mathrm{a}$ & 2.50 & \\
\hline S11T011070 & Bismuth & $\mathrm{ug} / \mathrm{mL}$ & 97.0 & $\mathrm{n} / \mathrm{a}$ & $<250$ & $\mathrm{n} / \mathrm{a}$ & $\mathrm{n} / \mathrm{a}$ & $\mathrm{n} / \mathrm{a}$ & $\mathrm{n} / \mathrm{a}$ & 250 & \\
\hline S11T011070 & Calcium & $\mathrm{ug} / \mathrm{mL}$ & 110 & $<0.0500$ & $<125$ & $\mathrm{n} / \mathrm{a}$ & $\mathrm{n} / \mathrm{a}$ & $\mathrm{n} / \mathrm{a}$ & $\mathrm{n} / \mathrm{a}$ & 125 & $\mathrm{U}$ \\
\hline S11T011070 & Cadmium & $\mathrm{ug} / \mathrm{mL}$ & 98.1 & $\mathrm{n} / \mathrm{a}$ & $<12.5$ & $\mathrm{n} / \mathrm{a}$ & $\mathrm{n} / \mathrm{a}$ & $\mathrm{n} / \mathrm{a}$ & $\mathrm{n} / \mathrm{a}$ & 12.5 & \\
\hline S11T011070 & Cerium & $\mathrm{ug} / \mathrm{mL}$ & 99.4 & $\mathrm{n} / \mathrm{a}$ & $<75.0$ & $\mathrm{n} / \mathrm{a}$ & $\mathrm{n} / \mathrm{a}$ & $\mathrm{n} / \mathrm{a}$ & $\mathrm{n} / \mathrm{a}$ & 75.0 & \\
\hline S11T011070 & Cobalt & $\mathrm{ug} / \mathrm{mL}$ & 98.1 & $\mathrm{n} / \mathrm{a}$ & $<25.0$ & $\mathrm{n} / \mathrm{a}$ & $\mathrm{n} / \mathrm{a}$ & $\mathrm{n} / \mathrm{a}$ & $\mathrm{n} / \mathrm{a}$ & 25.0 & \\
\hline S11T011070 & Chromium & $\mathrm{ug} / \mathrm{mL}$ & 98.1 & $<5.00 \mathrm{E}-03$ & $1.53 \mathrm{E}+03$ & $\mathrm{n} / \mathrm{a}$ & $\mathrm{n} / \mathrm{a}$ & $\mathrm{n} / \mathrm{a}$ & $\mathrm{n} / \mathrm{a}$ & 12.5 & \\
\hline S11T011070 & Copper & $\mathrm{ug} / \mathrm{mL}$ & 99.8 & $\mathrm{n} / \mathrm{a}$ & $<12.5$ & $\mathrm{n} / \mathrm{a}$ & $\mathrm{n} / \mathrm{a}$ & $\mathrm{n} / \mathrm{a}$ & $\mathrm{n} / \mathrm{a}$ & 12.5 & \\
\hline S11T011070 & Europium & $\mathrm{ug} / \mathrm{mL}$ & 94.3 & $\mathrm{n} / \mathrm{a}$ & $<12.5$ & $\mathrm{n} / \mathrm{a}$ & $\mathrm{n} / \mathrm{a}$ & $\mathrm{n} / \mathrm{a}$ & $\mathrm{n} / \mathrm{a}$ & 12.5 & \\
\hline S11T011070 & Iron & $\mathrm{ug} / \mathrm{mL}$ & 99.6 & $\mathrm{n} / \mathrm{a}$ & $<12.5$ & $\mathrm{n} / \mathrm{a}$ & $\mathrm{n} / \mathrm{a}$ & $\mathrm{n} / \mathrm{a}$ & $\mathrm{n} / \mathrm{a}$ & 12.5 & \\
\hline S11T011070 & Potassium & $\mathrm{ug} / \mathrm{mL}$ & 91.2 & $<0.500$ & $4.23 \mathrm{E}+03$ & $\mathrm{n} / \mathrm{a}$ & $\mathrm{n} / \mathrm{a}$ & $\mathrm{n} / \mathrm{a}$ & $\mathrm{n} / \mathrm{a}$ & $1.25 \mathrm{E}+03$ & $\mathrm{~J}$ \\
\hline S11T011070 & Lanthanum & $\mathrm{ug} / \mathrm{mL}$ & 99.2 & $\mathrm{n} / \mathrm{a}$ & $<7.50$ & $\mathrm{n} / \mathrm{a}$ & $\mathrm{n} / \mathrm{a}$ & $\mathrm{n} / \mathrm{a}$ & $\mathrm{n} / \mathrm{a}$ & 7.50 & \\
\hline
\end{tabular}


Table D-8. Centrifuged Liquid from Sample CON 7. (2 sheets)

Sample Number(s): S11T011070 (Test Sample CON 7)

Sample Group: 20111225

\begin{tabular}{|c|c|c|c|c|c|c|c|c|c|c|c|}
\hline Sample \# & Analyte & Unit & $\begin{array}{c}\text { Std } \\
\%-\operatorname{Rec}\end{array}$ & Blank & Result & Duplicate & Average & RPD & $\begin{array}{c}\text { Spk } \\
\text { \%-Rec }\end{array}$ & $\begin{array}{c}\text { Det } \\
\text { Limit }\end{array}$ & $\begin{array}{l}\text { Qual } \\
\text { Flags }\end{array}$ \\
\hline S11T011070 & Lithium & $\mathrm{ug} / \mathrm{mL}$ & 107 & $\mathrm{n} / \mathrm{a}$ & $<7.50$ & $\mathrm{n} / \mathrm{a}$ & $\mathrm{n} / \mathrm{a}$ & $\mathrm{n} / \mathrm{a}$ & $\mathrm{n} / \mathrm{a}$ & 7.50 & \\
\hline S11T011070 & Magnesium & $\mathrm{ug} / \mathrm{mL}$ & 99.5 & $\mathrm{n} / \mathrm{a}$ & $<125$ & $\mathrm{n} / \mathrm{a}$ & $\mathrm{n} / \mathrm{a}$ & $\mathrm{n} / \mathrm{a}$ & $\mathrm{n} / \mathrm{a}$ & 125 & \\
\hline S11T011070 & Manganese & $\mathrm{ug} / \mathrm{mL}$ & 96.4 & $\mathrm{n} / \mathrm{a}$ & $<7.50$ & $\mathrm{n} / \mathrm{a}$ & $\mathrm{n} / \mathrm{a}$ & $\mathrm{n} / \mathrm{a}$ & $\mathrm{n} / \mathrm{a}$ & 7.50 & \\
\hline S11T011070 & Molybdenum & $\mathrm{ug} / \mathrm{mL}$ & 98.4 & $\mathrm{n} / \mathrm{a}$ & 86.5 & $\mathrm{n} / \mathrm{a}$ & $\mathrm{n} / \mathrm{a}$ & $\mathrm{n} / \mathrm{a}$ & $\mathrm{n} / \mathrm{a}$ & 50.0 & \\
\hline S11T011070 & Sodium & $\mathrm{ug} / \mathrm{mL}$ & 107 & $<0.100$ & $2.16 \mathrm{E}+05$ & $\mathrm{n} / \mathrm{a}$ & $\mathrm{n} / \mathrm{a}$ & $\mathrm{n} / \mathrm{a}$ & $\mathrm{n} / \mathrm{a}$ & 250 & \\
\hline S11T011070 & Neodymium & $\mathrm{ug} / \mathrm{mL}$ & 97.4 & $\mathrm{n} / \mathrm{a}$ & $<25.0$ & $\mathrm{n} / \mathrm{a}$ & $\mathrm{n} / \mathrm{a}$ & $\mathrm{n} / \mathrm{a}$ & $\mathrm{n} / \mathrm{a}$ & 25.0 & \\
\hline S11T011070 & Nickel & $\mathrm{ug} / \mathrm{mL}$ & 97.3 & $\mathrm{n} / \mathrm{a}$ & $<50.0$ & $\mathrm{n} / \mathrm{a}$ & $\mathrm{n} / \mathrm{a}$ & $\mathrm{n} / \mathrm{a}$ & $\mathrm{n} / \mathrm{a}$ & 50.0 & \\
\hline S11T011070 & Phosphorus & $\mathrm{ug} / \mathrm{mL}$ & 99.1 & $<0.0500$ & 885 & $\mathrm{n} / \mathrm{a}$ & $\mathrm{n} / \mathrm{a}$ & $\mathrm{n} / \mathrm{a}$ & $\mathrm{n} / \mathrm{a}$ & 125 & $\mathrm{~J}$ \\
\hline S11T011070 & Lead & $\mathrm{ug} / \mathrm{mL}$ & 101 & $\mathrm{n} / \mathrm{a}$ & $<125$ & $\mathrm{n} / \mathrm{a}$ & $\mathrm{n} / \mathrm{a}$ & $\mathrm{n} / \mathrm{a}$ & $\mathrm{n} / \mathrm{a}$ & 125 & \\
\hline S11T011070 & Sulfur & $\mathrm{ug} / \mathrm{mL}$ & 99.2 & $<0.100$ & $5.67 \mathrm{E}+03$ & $\mathrm{n} / \mathrm{a}$ & $\mathrm{n} / \mathrm{a}$ & $\mathrm{n} / \mathrm{a}$ & $\mathrm{n} / \mathrm{a}$ & 250 & \\
\hline S11T011070 & Antimony & $\mathrm{ug} / \mathrm{mL}$ & 95.3 & $\mathrm{n} / \mathrm{a}$ & $<125$ & $\mathrm{n} / \mathrm{a}$ & $\mathrm{n} / \mathrm{a}$ & $\mathrm{n} / \mathrm{a}$ & $\mathrm{n} / \mathrm{a}$ & 125 & \\
\hline S11T011070 & Selenium & $\mathrm{ug} / \mathrm{mL}$ & 101 & $\mathrm{n} / \mathrm{a}$ & $<250$ & $\mathrm{n} / \mathrm{a}$ & $\mathrm{n} / \mathrm{a}$ & $\mathrm{n} / \mathrm{a}$ & $\mathrm{n} / \mathrm{a}$ & 250 & \\
\hline S11T011070 & Silicon & $\mathrm{ug} / \mathrm{mL}$ & 96.7 & $<0.0300$ & 158 & $\mathrm{n} / \mathrm{a}$ & $\mathrm{n} / \mathrm{a}$ & $\mathrm{n} / \mathrm{a}$ & $\mathrm{n} / \mathrm{a}$ & 75.0 & $\mathrm{~J}$ \\
\hline S11T011070 & Samarium & $\mathrm{ug} / \mathrm{mL}$ & 102 & $\mathrm{n} / \mathrm{a}$ & $<125$ & $\mathrm{n} / \mathrm{a}$ & $\mathrm{n} / \mathrm{a}$ & $\mathrm{n} / \mathrm{a}$ & $\mathrm{n} / \mathrm{a}$ & 125 & \\
\hline $\mathrm{S} 11 \mathrm{~T} 011070$ & Strontium & $\mathrm{ug} / \mathrm{mL}$ & 98.3 & $\mathrm{n} / \mathrm{a}$ & $<7.50$ & $\mathrm{n} / \mathrm{a}$ & $\mathrm{n} / \mathrm{a}$ & $\mathrm{n} / \mathrm{a}$ & $\mathrm{n} / \mathrm{a}$ & 7.50 & \\
\hline S11T011070 & Thorium & $\mathrm{ug} / \mathrm{mL}$ & 97.3 & $\mathrm{n} / \mathrm{a}$ & $<125$ & $\mathrm{n} / \mathrm{a}$ & $\mathrm{n} / \mathrm{a}$ & $\mathrm{n} / \mathrm{a}$ & $\mathrm{n} / \mathrm{a}$ & 125 & \\
\hline S11T011070 & Titanium & $\mathrm{ug} / \mathrm{mL}$ & 96.6 & $\mathrm{n} / \mathrm{a}$ & $<12.5$ & $\mathrm{n} / \mathrm{a}$ & $\mathrm{n} / \mathrm{a}$ & $\mathrm{n} / \mathrm{a}$ & $\mathrm{n} / \mathrm{a}$ & 12.5 & \\
\hline S11T011070 & Thallium & $\mathrm{ug} / \mathrm{mL}$ & 97.3 & $\mathrm{n} / \mathrm{a}$ & $<250$ & $\mathrm{n} / \mathrm{a}$ & $\mathrm{n} / \mathrm{a}$ & $\mathrm{n} / \mathrm{a}$ & $\mathrm{n} / \mathrm{a}$ & 250 & \\
\hline S11T011070 & Uranium & $\mathrm{ug} / \mathrm{mL}$ & 99.5 & $\mathrm{n} / \mathrm{a}$ & $<250$ & $\mathrm{n} / \mathrm{a}$ & $\mathrm{n} / \mathrm{a}$ & $\mathrm{n} / \mathrm{a}$ & $\mathrm{n} / \mathrm{a}$ & 250 & \\
\hline S11T011070 & Vanadium & $\mathrm{ug} / \mathrm{mL}$ & 98.8 & $\mathrm{n} / \mathrm{a}$ & $<12.5$ & $\mathrm{n} / \mathrm{a}$ & $\mathrm{n} / \mathrm{a}$ & $\mathrm{n} / \mathrm{a}$ & $\mathrm{n} / \mathrm{a}$ & 12.5 & \\
\hline $\mathrm{S} 11 \mathrm{~T} 011070$ & Yttrium & $\mathrm{ug} / \mathrm{mL}$ & 94.7 & $\mathrm{n} / \mathrm{a}$ & $<5.00$ & $\mathrm{n} / \mathrm{a}$ & $\mathrm{n} / \mathrm{a}$ & $\mathrm{n} / \mathrm{a}$ & $\mathrm{n} / \mathrm{a}$ & 5.00 & \\
\hline S11T011070 & Zinc & $\mathrm{ug} / \mathrm{mL}$ & 96.6 & $\mathrm{n} / \mathrm{a}$ & $<12.5$ & $\mathrm{n} / \mathrm{a}$ & $\mathrm{n} / \mathrm{a}$ & $\mathrm{n} / \mathrm{a}$ & $\mathrm{n} / \mathrm{a}$ & 12.5 & \\
\hline S11T011070 & Zirconium & $\mathrm{ug} / \mathrm{mL}$ & 98.7 & $\mathrm{n} / \mathrm{a}$ & $<12.5$ & $\mathrm{n} / \mathrm{a}$ & $\mathrm{n} / \mathrm{a}$ & $\mathrm{n} / \mathrm{a}$ & $\mathrm{n} / \mathrm{a}$ & 12.5 & \\
\hline S11T011070 & Hydroxide & $\mathrm{ug} / \mathrm{mL}$ & 105 & $<41.7$ & $2.5 \mathrm{E}+04$ & $\mathrm{n} / \mathrm{a}$ & $\mathrm{n} / \mathrm{a}$ & $\mathrm{n} / \mathrm{a}$ & $\mathrm{n} / \mathrm{a}$ & 550 & \\
\hline S11T011070 & Specific gravity & unitless & 100.5 & $\mathrm{n} / \mathrm{a}$ & 1.342 & $\mathrm{n} / \mathrm{a}$ & $\mathrm{n} / \mathrm{a}$ & $\mathrm{n} / \mathrm{a}$ & $\mathrm{n} / \mathrm{a}$ & $1.00 \mathrm{E}-03$ & \\
\hline $\mathrm{S} 11 \mathrm{~T} 011070$ & Total organic carbon & $\mathrm{ug} / \mathrm{mL}$ & 96.5 & $<20.0$ & 946 & $\mathrm{n} / \mathrm{a}$ & $\mathrm{n} / \mathrm{a}$ & $\mathrm{n} / \mathrm{a}$ & $\mathrm{n} / \mathrm{a}$ & 200 & $\mathrm{~J}$ \\
\hline S11T011070 & Total inorganic carbon & $\mathrm{ug} / \mathrm{mL}$ & 98.7 & $<7.00$ & $6.39 \mathrm{E}+03$ & $\mathrm{n} / \mathrm{a}$ & $\mathrm{n} / \mathrm{a}$ & $\mathrm{n} / \mathrm{a}$ & $\mathrm{n} / \mathrm{a}$ & 70.0 & \\
\hline S11T011070 & Total carbon & $\mathrm{ug} / \mathrm{mL}$ & 97.2 & $<5.00$ & $1.23 \mathrm{E}+04$ & $\mathrm{n} / \mathrm{a}$ & $\mathrm{n} / \mathrm{a}$ & $\mathrm{n} / \mathrm{a}$ & $\mathrm{n} / \mathrm{a}$ & 55.0 & \\
\hline
\end{tabular}


Table D-9. Centrifuged Liquid from Sample DIL 1. (2 sheets)

Sample Number(s): S11T011071 (Test Sample DIL 1)

Sample Group: 20111225

\begin{tabular}{|c|c|c|c|c|c|c|c|c|c|c|c|}
\hline Sample \# & Analyte & Unit & $\begin{array}{c}\text { Std } \\
\% \text {-Rec }\end{array}$ & Blank & Result & Duplicate & Average & RPD & $\begin{array}{c}\text { Spk } \\
\% \text {-Rec }\end{array}$ & $\begin{array}{c}\text { Det } \\
\text { Limit }\end{array}$ & $\begin{array}{l}\text { Qual } \\
\text { Flags }\end{array}$ \\
\hline S11T011071 & Fluoride & $\mathrm{ug} / \mathrm{mL}$ & 103 & $<1.61 \mathrm{E}-03$ & 585 & $\mathrm{n} / \mathrm{a}$ & $\mathrm{n} / \mathrm{a}$ & $\mathrm{n} / \mathrm{a}$ & $\mathrm{n} / \mathrm{a}$ & 1.61 & \\
\hline S11T011071 & \begin{tabular}{|l|} 
Glycolate \\
\end{tabular} & $\mathrm{ug} / \mathrm{mL}$ & 98.8 & $<<9.37 \mathrm{E}-03$ & 228 & $\mathrm{n} / \mathrm{a}$ & $\mathrm{n} / \mathrm{a}$ & $\mathrm{n} / \mathrm{a}$ & $\mathrm{n} / \mathrm{a}$ & 9.37 & \\
\hline S11T011071 & Acetate & $\mathrm{ug} / \mathrm{mL}$ & 97.0 & $<6.04 \mathrm{E}-03$ & 265 & $\mathrm{n} / \mathrm{a}$ & $\mathrm{n} / \mathrm{a}$ & $\mathrm{n} / \mathrm{a}$ & $\mathrm{n} / \mathrm{a}$ & 6.04 & \\
\hline S11T011071 & Formate & $\mathrm{ug} / \mathrm{mL}$ & 99.7 & $<4.67 \mathrm{E}-03$ & 810 & $\mathrm{n} / \mathrm{a}$ & $\mathrm{n} / \mathrm{a}$ & $\mathrm{n} / \mathrm{a}$ & $\mathrm{n} / \mathrm{a}$ & 4.67 & \\
\hline S11T011071 & Chloride & $\mathrm{ug} / \mathrm{mL}$ & 99.3 & 0.0132 & $1.75 \mathrm{E}+03$ & $\mathrm{n} / \mathrm{a}$ & $\mathrm{n} / \mathrm{a}$ & $\mathrm{n} / \mathrm{a}$ & $\mathrm{n} / \mathrm{a}$ & 9.98 & \\
\hline S11T011071 & Nitrite & $\mathrm{ug} / \mathrm{mL}$ & 101 & $<0.0192$ & $3.80 \mathrm{E}+04$ & n/a & $\mathrm{n} / \mathrm{a}$ & $\mathrm{n} / \mathrm{a}$ & $\mathrm{n} / \mathrm{a}$ & 96.0 & \\
\hline S11T011071 & Sulfate & $\mathrm{ug} / \mathrm{mL}$ & 102 & $<0.0187$ & $1.13 \mathrm{E}+04$ & $\mathrm{n} / \mathrm{a}$ & $\mathrm{n} / \mathrm{a}$ & $\mathrm{n} / \mathrm{a}$ & $\mathrm{n} / \mathrm{a}$ & 18.7 & \\
\hline S11T011071 & \begin{tabular}{|l|} 
Oxalate \\
\end{tabular} & $\mathrm{ug} / \mathrm{mL}$ & 102 & $<0.0231$ & 931 & $\mathrm{n} / \mathrm{a}$ & $\mathrm{n} / \mathrm{a}$ & $\mathrm{n} / \mathrm{a}$ & $\mathrm{n} / \mathrm{a}$ & 23.1 & \\
\hline S11T011071 & Bromide & $\mathrm{ug} / \mathrm{mL}$ & 101 & $<0.0580$ & $<58.0$ & $\mathrm{n} / \mathrm{a}$ & $\mathrm{n} / \mathrm{a}$ & $\mathrm{n} / \mathrm{a}$ & $\mathrm{n} / \mathrm{a}$ & 58.0 & $\mathrm{U}$ \\
\hline S11T011071 & Nitrate & $\mathrm{ug} / \mathrm{mL}$ & 101 & 0.0715 & $1.48 \mathrm{E}+05$ & $\mathrm{n} / \mathrm{a}$ & $\mathrm{n} / \mathrm{a}$ & $\mathrm{n} / \mathrm{a}$ & $\mathrm{n} / \mathrm{a}$ & 208 & \\
\hline S11T011071 & Phosphate & $\mathrm{ug} / \mathrm{mL}$ & 101 & $<0.0167$ & $3.63 \mathrm{E}+03$ & $\mathrm{n} / \mathrm{a}$ & $\mathrm{n} / \mathrm{a}$ & $\mathrm{n} / \mathrm{a}$ & $\mathrm{n} / \mathrm{a}$ & 16.7 & \\
\hline S11T011071 & Silver & $\mathrm{ug} / \mathrm{mL}$ & 97.6 & $\mathrm{n} / \mathrm{a}$ & $<12.5$ & $\mathrm{n} / \mathrm{a}$ & $\mathrm{n} / \mathrm{a}$ & $\mathrm{n} / \mathrm{a}$ & $\mathrm{n} / \mathrm{a}$ & 12.5 & \\
\hline S11T011071 & Aluminum & $\mathrm{ug} / \mathrm{mL}$ & 100 & $<0.0300$ & $4.99 \mathrm{E}+03$ & $\mathrm{n} / \mathrm{a}$ & $\mathrm{n} / \mathrm{a}$ & $\mathrm{n} / \mathrm{a}$ & $\mathrm{n} / \mathrm{a}$ & 75.0 & \\
\hline S11T011071 & Arsenic & $\mathrm{ug} / \mathrm{mL}$ & 100 & $\mathrm{n} / \mathrm{a}$ & $<125$ & $\mathrm{n} / \mathrm{a}$ & $\mathrm{n} / \mathrm{a}$ & $\mathrm{n} / \mathrm{a}$ & $\mathrm{n} / \mathrm{a}$ & 125 & \\
\hline S11T011071 & Boron & $\mathrm{ug} / \mathrm{mL}$ & 99.2 & $\mathrm{n} / \mathrm{a}$ & $<75.0$ & $\mathrm{n} / \mathrm{a}$ & $\mathrm{n} / \mathrm{a}$ & $\mathrm{n} / \mathrm{a}$ & $\mathrm{n} / \mathrm{a}$ & 75.0 & \\
\hline S11T011071 & Barium & $\mathrm{ug} / \mathrm{mL}$ & 99.0 & $\mathrm{n} / \mathrm{a}$ & $<7.50$ & $\mathrm{n} / \mathrm{a}$ & $\mathrm{n} / \mathrm{a}$ & $\mathrm{n} / \mathrm{a}$ & $\mathrm{n} / \mathrm{a}$ & 7.50 & \\
\hline S11T011071 & Beryllium & $\mathrm{ug} / \mathrm{mL}$ & 97.5 & $\mathrm{n} / \mathrm{a}$ & $<2.50$ & $\mathrm{n} / \mathrm{a}$ & $\mathrm{n} / \mathrm{a}$ & $\mathrm{n} / \mathrm{a}$ & $\mathrm{n} / \mathrm{a}$ & 2.50 & \\
\hline S11T011071 & Bismuth & $\mathrm{ug} / \mathrm{mL}$ & 97.0 & $\mathrm{n} / \mathrm{a}$ & $<250$ & $\mathrm{n} / \mathrm{a}$ & $\mathrm{n} / \mathrm{a}$ & $\mathrm{n} / \mathrm{a}$ & $\mathrm{n} / \mathrm{a}$ & 250 & \\
\hline S11T011071 & \begin{tabular}{|l|} 
Calcium \\
\end{tabular} & $\mathrm{ug} / \mathrm{mL}$ & 110 & $<0.0500$ & $<125$ & $\mathrm{n} / \mathrm{a}$ & $\mathrm{n} / \mathrm{a}$ & $\mathrm{n} / \mathrm{a}$ & $\mathrm{n} / \mathrm{a}$ & 125 & $\mathrm{U}$ \\
\hline S11T011071 & Cadmium & $\mathrm{ug} / \mathrm{mL}$ & 98.1 & $\mathrm{n} / \mathrm{a}$ & $<12.5$ & $\mathrm{n} / \mathrm{a}$ & $\mathrm{n} / \mathrm{a}$ & $\mathrm{n} / \mathrm{a}$ & $\mathrm{n} / \mathrm{a}$ & 12.5 & \\
\hline S11T011071 & Cerium & $\mathrm{ug} / \mathrm{mL}$ & 99.4 & $\mathrm{n} / \mathrm{a}$ & $<75.0$ & $\mathrm{n} / \mathrm{a}$ & $\mathrm{n} / \mathrm{a}$ & $\mathrm{n} / \mathrm{a}$ & $\mathrm{n} / \mathrm{a}$ & 75.0 & \\
\hline S11T011071 & Cobalt & $\mathrm{ug} / \mathrm{mL}$ & 98.1 & $\mathrm{n} / \mathrm{a}$ & $<25.0$ & $\mathrm{n} / \mathrm{a}$ & $\mathrm{n} / \mathrm{a}$ & $\mathrm{n} / \mathrm{a}$ & $\mathrm{n} / \mathrm{a}$ & 25.0 & \\
\hline S11T011071 & Chromium & $\mathrm{ug} / \mathrm{mL}$ & 98.1 & $<5.00 \mathrm{E}-03$ & 651 & $\mathrm{n} / \mathrm{a}$ & $\mathrm{n} / \mathrm{a}$ & $\mathrm{n} / \mathrm{a}$ & $\mathrm{n} / \mathrm{a}$ & 12.5 & \\
\hline S11T011071 & \begin{tabular}{|l|} 
Copper \\
\end{tabular} & $\mathrm{ug} / \mathrm{mL}$ & 99.8 & $\mathrm{n} / \mathrm{a}$ & $<12.5$ & $\mathrm{n} / \mathrm{a}$ & $\mathrm{n} / \mathrm{a}$ & $\mathrm{n} / \mathrm{a}$ & $\mathrm{n} / \mathrm{a}$ & 12.5 & \\
\hline S11T011071 & Europium & $\mathrm{ug} / \mathrm{mL}$ & 94.3 & $\mathrm{n} / \mathrm{a}$ & $<12.5$ & $\mathrm{n} / \mathrm{a}$ & $\mathrm{n} / \mathrm{a}$ & $\mathrm{n} / \mathrm{a}$ & $\mathrm{n} / \mathrm{a}$ & 12.5 & \\
\hline S11T011071 & Iron & $\mathrm{ug} / \mathrm{mL}$ & 99.6 & $\mathrm{n} / \mathrm{a}$ & $<12.5$ & $\mathrm{n} / \mathrm{a}$ & $\mathrm{n} / \mathrm{a}$ & $\mathrm{n} / \mathrm{a}$ & $\mathrm{n} / \mathrm{a}$ & 12.5 & \\
\hline S11T011071 & Potassium & $\mathrm{ug} / \mathrm{mL}$ & 91.2 & $<0.500$ & $1.85 \mathrm{E}+03$ & $\mathrm{n} / \mathrm{a}$ & $\mathrm{n} / \mathrm{a}$ & $\mathrm{n} / \mathrm{a}$ & $\mathrm{n} / \mathrm{a}$ & $1.25 \mathrm{E}+03$ & $\mathrm{~J}$ \\
\hline S11T011071 & Lanthanum & $\mathrm{ug} / \mathrm{mL}$ & 99.2 & $\mathrm{n} / \mathrm{a}$ & $<7.50$ & $\mathrm{n} / \mathrm{a}$ & $\mathrm{n} / \mathrm{a}$ & $\mathrm{n} / \mathrm{a}$ & $\mathrm{n} / \mathrm{a}$ & 7.50 & \\
\hline
\end{tabular}


Table D-9. Centrifuged Liquid from Sample DIL 1. (2 sheets)

Sample Number(s): S11T011071 (Test Sample DIL 1)

Sample Group: 20111225

\begin{tabular}{|c|c|c|c|c|c|c|c|c|c|c|c|}
\hline Sample \# & Analyte & Unit & $\begin{array}{c}\text { Std } \\
\%-\operatorname{Rec}\end{array}$ & Blank & Result & Duplicate & Average & RPD & $\begin{array}{c}\text { Spk } \\
\text { \%-Rec }\end{array}$ & $\begin{array}{c}\text { Det } \\
\text { Limit }\end{array}$ & $\begin{array}{l}\text { Qual } \\
\text { Flags }\end{array}$ \\
\hline S11T011071 & Lithium & $\mathrm{ug} / \mathrm{mL}$ & 107 & $\mathrm{n} / \mathrm{a}$ & $<7.50$ & $\mathrm{n} / \mathrm{a}$ & $\mathrm{n} / \mathrm{a}$ & $\mathrm{n} / \mathrm{a}$ & $\mathrm{n} / \mathrm{a}$ & 7.50 & \\
\hline S11T011071 & Magnesium & $\mathrm{ug} / \mathrm{mL}$ & 99.5 & $\mathrm{n} / \mathrm{a}$ & $<125$ & $\mathrm{n} / \mathrm{a}$ & $\mathrm{n} / \mathrm{a}$ & $\mathrm{n} / \mathrm{a}$ & $\mathrm{n} / \mathrm{a}$ & 125 & \\
\hline S11T011071 & Manganese & $\mathrm{ug} / \mathrm{mL}$ & 96.4 & $\mathrm{n} / \mathrm{a}$ & $<7.50$ & $\mathrm{n} / \mathrm{a}$ & $\mathrm{n} / \mathrm{a}$ & $\mathrm{n} / \mathrm{a}$ & $\mathrm{n} / \mathrm{a}$ & 7.50 & \\
\hline S11T011071 & Molybdenum & $\mathrm{ug} / \mathrm{mL}$ & 98.4 & $\mathrm{n} / \mathrm{a}$ & $<50.0$ & $\mathrm{n} / \mathrm{a}$ & $\mathrm{n} / \mathrm{a}$ & $\mathrm{n} / \mathrm{a}$ & $\mathrm{n} / \mathrm{a}$ & 50.0 & \\
\hline S11T011071 & Sodium & $\mathrm{ug} / \mathrm{mL}$ & 107 & $<0.100$ & $1.21 \mathrm{E}+05$ & $\mathrm{n} / \mathrm{a}$ & $\mathrm{n} / \mathrm{a}$ & $\mathrm{n} / \mathrm{a}$ & $\mathrm{n} / \mathrm{a}$ & 250 & \\
\hline S11T011071 & Neodymium & $\mathrm{ug} / \mathrm{mL}$ & 97.4 & $\mathrm{n} / \mathrm{a}$ & $<25.0$ & $\mathrm{n} / \mathrm{a}$ & $\mathrm{n} / \mathrm{a}$ & $\mathrm{n} / \mathrm{a}$ & $\mathrm{n} / \mathrm{a}$ & 25.0 & \\
\hline S11T011071 & Nickel & $\mathrm{ug} / \mathrm{mL}$ & 97.3 & $\mathrm{n} / \mathrm{a}$ & $<50.0$ & $\mathrm{n} / \mathrm{a}$ & $\mathrm{n} / \mathrm{a}$ & $\mathrm{n} / \mathrm{a}$ & $\mathrm{n} / \mathrm{a}$ & 50.0 & \\
\hline S11T011071 & Phosphorus & $\mathrm{ug} / \mathrm{mL}$ & 99.1 & $<0.0500$ & $1.05 \mathrm{E}+03$ & $\mathrm{n} / \mathrm{a}$ & $\mathrm{n} / \mathrm{a}$ & $\mathrm{n} / \mathrm{a}$ & $\mathrm{n} / \mathrm{a}$ & 125 & $\mathrm{~J}$ \\
\hline S11T011071 & Lead & $\mathrm{ug} / \mathrm{mL}$ & 101 & $\mathrm{n} / \mathrm{a}$ & $<125$ & $\mathrm{n} / \mathrm{a}$ & $\mathrm{n} / \mathrm{a}$ & $\mathrm{n} / \mathrm{a}$ & $\mathrm{n} / \mathrm{a}$ & 125 & \\
\hline S11T011071 & Sulfur & $\mathrm{ug} / \mathrm{mL}$ & 99.2 & $<0.100$ & $3.52 \mathrm{E}+03$ & $\mathrm{n} / \mathrm{a}$ & $\mathrm{n} / \mathrm{a}$ & $\mathrm{n} / \mathrm{a}$ & $\mathrm{n} / \mathrm{a}$ & 250 & \\
\hline S11T011071 & Antimony & $\mathrm{ug} / \mathrm{mL}$ & 95.3 & $\mathrm{n} / \mathrm{a}$ & $<125$ & $\mathrm{n} / \mathrm{a}$ & $\mathrm{n} / \mathrm{a}$ & $\mathrm{n} / \mathrm{a}$ & $\mathrm{n} / \mathrm{a}$ & 125 & \\
\hline S11T011071 & Selenium & $\mathrm{ug} / \mathrm{mL}$ & 101 & $\mathrm{n} / \mathrm{a}$ & $<250$ & $\mathrm{n} / \mathrm{a}$ & $\mathrm{n} / \mathrm{a}$ & $\mathrm{n} / \mathrm{a}$ & $\mathrm{n} / \mathrm{a}$ & 250 & \\
\hline S11T011071 & Silicon & $\mathrm{ug} / \mathrm{mL}$ & 96.7 & $<0.0300$ & 142 & $\mathrm{n} / \mathrm{a}$ & $\mathrm{n} / \mathrm{a}$ & $\mathrm{n} / \mathrm{a}$ & $\mathrm{n} / \mathrm{a}$ & 75.0 & $\mathrm{~J}$ \\
\hline S11T011071 & Samarium & $\mathrm{ug} / \mathrm{mL}$ & 102 & $\mathrm{n} / \mathrm{a}$ & $<125$ & $\mathrm{n} / \mathrm{a}$ & $\mathrm{n} / \mathrm{a}$ & $\mathrm{n} / \mathrm{a}$ & $\mathrm{n} / \mathrm{a}$ & 125 & \\
\hline S11T011071 & Strontium & $\mathrm{ug} / \mathrm{mL}$ & 98.3 & $\mathrm{n} / \mathrm{a}$ & $<7.50$ & $\mathrm{n} / \mathrm{a}$ & $\mathrm{n} / \mathrm{a}$ & n/a & $\mathrm{n} / \mathrm{a}$ & 7.50 & \\
\hline S11T011071 & Thorium & $\mathrm{ug} / \mathrm{mL}$ & 97.3 & $\mathrm{n} / \mathrm{a}$ & $<125$ & $\mathrm{n} / \mathrm{a}$ & $\mathrm{n} / \mathrm{a}$ & $\mathrm{n} / \mathrm{a}$ & $\mathrm{n} / \mathrm{a}$ & 125 & \\
\hline S11T011071 & Titanium & $\mathrm{ug} / \mathrm{mL}$ & 96.6 & $\mathrm{n} / \mathrm{a}$ & $<12.5$ & $\mathrm{n} / \mathrm{a}$ & $\mathrm{n} / \mathrm{a}$ & $\mathrm{n} / \mathrm{a}$ & $\mathrm{n} / \mathrm{a}$ & 12.5 & \\
\hline S11T011071 & Thallium & $\mathrm{ug} / \mathrm{mL}$ & 97.3 & $\mathrm{n} / \mathrm{a}$ & $<250$ & $\mathrm{n} / \mathrm{a}$ & $\mathrm{n} / \mathrm{a}$ & $\mathrm{n} / \mathrm{a}$ & $\mathrm{n} / \mathrm{a}$ & 250 & \\
\hline S11T011071 & Uranium & $\mathrm{ug} / \mathrm{mL}$ & 99.5 & $\mathrm{n} / \mathrm{a}$ & $<250$ & $n / a$ & $\mathrm{n} / \mathrm{a}$ & $\mathrm{n} / \mathrm{a}$ & $\mathrm{n} / \mathrm{a}$ & 250 & \\
\hline S11T011071 & Vanadium & $\mathrm{ug} / \mathrm{mL}$ & 98.8 & $\mathrm{n} / \mathrm{a}$ & $<12.5$ & $\mathrm{n} / \mathrm{a}$ & $\mathrm{n} / \mathrm{a}$ & $\mathrm{n} / \mathrm{a}$ & $\mathrm{n} / \mathrm{a}$ & 12.5 & \\
\hline S11T011071 & Yttrium & $\mathrm{ug} / \mathrm{mL}$ & 94.7 & $\mathrm{n} / \mathrm{a}$ & $<5.00$ & $\mathrm{n} / \mathrm{a}$ & $\mathrm{n} / \mathrm{a}$ & $\mathrm{n} / \mathrm{a}$ & $\mathrm{n} / \mathrm{a}$ & 5.00 & \\
\hline S11T011071 & Zinc & $\mathrm{ug} / \mathrm{mL}$ & 96.6 & $\mathrm{n} / \mathrm{a}$ & $<12.5$ & $\mathrm{n} / \mathrm{a}$ & $\mathrm{n} / \mathrm{a}$ & $\mathrm{n} / \mathrm{a}$ & $\mathrm{n} / \mathrm{a}$ & 12.5 & \\
\hline S11T011071 & Zirconium & $\mathrm{ug} / \mathrm{mL}$ & 98.7 & $\mathrm{n} / \mathrm{a}$ & $<12.5$ & $\mathrm{n} / \mathrm{a}$ & $\mathrm{n} / \mathrm{a}$ & $\mathrm{n} / \mathrm{a}$ & $\mathrm{n} / \mathrm{a}$ & 12.5 & \\
\hline S11T011071 & Hydroxide & $\mathrm{ug} / \mathrm{mL}$ & 105 & $<41.7$ & $1.3 \mathrm{E}+04$ & $\mathrm{n} / \mathrm{a}$ & $\mathrm{n} / \mathrm{a}$ & $\mathrm{n} / \mathrm{a}$ & $\mathrm{n} / \mathrm{a}$ & 550 & \\
\hline S11T011071 & Specific gravity & unitless & 100.5 & $\mathrm{n} / \mathrm{a}$ & 1.292 & $\mathrm{n} / \mathrm{a}$ & $\mathrm{n} / \mathrm{a}$ & $\mathrm{n} / \mathrm{a}$ & $\mathrm{n} / \mathrm{a}$ & $1.00 \mathrm{E}-03$ & \\
\hline S11T011071 & Total organic carbon & $\mathrm{ug} / \mathrm{mL}$ & 96.5 & $<20.0$ & 991 & $\mathrm{n} / \mathrm{a}$ & $\mathrm{n} / \mathrm{a}$ & $\mathrm{n} / \mathrm{a}$ & $\mathrm{n} / \mathrm{a}$ & 200 & $\mathrm{~J}$ \\
\hline S11T011071 & Total inorganic carbon & $\mathrm{ug} / \mathrm{mL}$ & 98.7 & $<7.00$ & $6.37 \mathrm{E}+03$ & $\mathrm{n} / \mathrm{a}$ & $\mathrm{n} / \mathrm{a}$ & $\mathrm{n} / \mathrm{a}$ & $\mathrm{n} / \mathrm{a}$ & 70.0 & \\
\hline
\end{tabular}


Table D-10. Centrifuged Liquid from Sample DIL 2. (2 sheets)

Sample Number(s): S11T011072 (Test Sample DIL 2)

Sample Group: 20111225

\begin{tabular}{|c|c|c|c|c|c|c|c|c|c|c|c|}
\hline Sample \# & Analyte & Unit & $\begin{array}{c}\text { Std } \\
\%-\operatorname{Rec}\end{array}$ & Blank & Result & Duplicate & Average & RPD & $\begin{array}{c}\text { Spk } \\
\% \text {-Rec }\end{array}$ & $\begin{array}{c}\text { Det } \\
\text { Limit }\end{array}$ & $\begin{array}{l}\text { Qual } \\
\text { Flags }\end{array}$ \\
\hline S11T011072 & Fluoride & $\mathrm{ug} / \mathrm{mL}$ & 103 & $<1.61 \mathrm{E}-03$ & 555 & $\mathrm{n} / \mathrm{a}$ & $\mathrm{n} / \mathrm{a}$ & $\mathrm{n} / \mathrm{a}$ & $\mathrm{n} / \mathrm{a}$ & 1.61 & \\
\hline S11T011072 & Glycolate & $\mathrm{ug} / \mathrm{mL}$ & 98.8 & $<9.37 \mathrm{E}-03$ & 205 & $\mathrm{n} / \mathrm{a}$ & $\mathrm{n} / \mathrm{a}$ & $\mathrm{n} / \mathrm{a}$ & $\mathrm{n} / \mathrm{a}$ & 9.37 & \\
\hline S11T011072 & Acetate & $\mathrm{ug} / \mathrm{mL}$ & 97.0 & $<6.04 \mathrm{E}-03$ & 235 & $\mathrm{n} / \mathrm{a}$ & $\mathrm{n} / \mathrm{a}$ & $\mathrm{n} / \mathrm{a}$ & $\mathrm{n} / \mathrm{a}$ & 6.04 & \\
\hline S11T011072 & Formate & $\mathrm{ug} / \mathrm{mL}$ & 99.7 & $<4.67 \mathrm{E}-03$ & 762 & $\mathrm{n} / \mathrm{a}$ & $\mathrm{n} / \mathrm{a}$ & $\mathrm{n} / \mathrm{a}$ & $\mathrm{n} / \mathrm{a}$ & 4.67 & \\
\hline S11T011072 & Chloride & $\mathrm{ug} / \mathrm{mL}$ & 99.3 & 0.0132 & $1.65 \mathrm{E}+03$ & $\mathrm{n} / \mathrm{a}$ & $\mathrm{n} / \mathrm{a}$ & $\mathrm{n} / \mathrm{a}$ & $\mathrm{n} / \mathrm{a}$ & 9.98 & \\
\hline S11T011072 & Nitrite & $\mathrm{ug} / \mathrm{mL}$ & 101 & $<0.0192$ & $3.56 \mathrm{E}+04$ & $\mathrm{n} / \mathrm{a}$ & $\mathrm{n} / \mathrm{a}$ & $\mathrm{n} / \mathrm{a}$ & $\mathrm{n} / \mathrm{a}$ & 96.0 & \\
\hline S11T011072 & Sulfate & $\mathrm{ug} / \mathrm{mL}$ & 102 & $<0.0187$ & $1.07 \mathrm{E}+04$ & $\mathrm{n} / \mathrm{a}$ & $\mathrm{n} / \mathrm{a}$ & $\mathrm{n} / \mathrm{a}$ & $\mathrm{n} / \mathrm{a}$ & 18.7 & \\
\hline S11T011072 & Oxalate & $\mathrm{ug} / \mathrm{mL}$ & 102 & $<0.0231$ & $1.07 \mathrm{E}+03$ & $\mathrm{n} / \mathrm{a}$ & $\mathrm{n} / \mathrm{a}$ & $\mathrm{n} / \mathrm{a}$ & $\mathrm{n} / \mathrm{a}$ & 23.1 & \\
\hline S11T011072 & Bromide & $\mathrm{ug} / \mathrm{mL}$ & 101 & $<0.0580$ & $<58.0$ & $\mathrm{n} / \mathrm{a}$ & $\mathrm{n} / \mathrm{a}$ & $\mathrm{n} / \mathrm{a}$ & $\mathrm{n} / \mathrm{a}$ & 58.0 & $\mathrm{U}$ \\
\hline S11T011072 & Nitrate & $\mathrm{ug} / \mathrm{mL}$ & 101 & 0.0715 & $1.41 \mathrm{E}+05$ & $\mathrm{n} / \mathrm{a}$ & $\mathrm{n} / \mathrm{a}$ & $\mathrm{n} / \mathrm{a}$ & $\mathrm{n} / \mathrm{a}$ & 208 & \\
\hline S11T011072 & Phosphate & $\mathrm{ug} / \mathrm{mL}$ & 101 & $<0.0167$ & $3.45 \mathrm{E}+03$ & $\mathrm{n} / \mathrm{a}$ & $\mathrm{n} / \mathrm{a}$ & $\mathrm{n} / \mathrm{a}$ & $\mathrm{n} / \mathrm{a}$ & 16.7 & \\
\hline S11T011072 & \begin{tabular}{|l|} 
Silver \\
\end{tabular} & $\mathrm{ug} / \mathrm{mL}$ & 97.6 & $\mathrm{n} / \mathrm{a}$ & $<12.5$ & $\mathrm{n} / \mathrm{a}$ & $\mathrm{n} / \mathrm{a}$ & $\mathrm{n} / \mathrm{a}$ & $\mathrm{n} / \mathrm{a}$ & 12.5 & \\
\hline S11T011072 & Aluminum & $\mathrm{ug} / \mathrm{mL}$ & 100 & $<0.0300$ & $5.35 \mathrm{E}+03$ & $\mathrm{n} / \mathrm{a}$ & $\mathrm{n} / \mathrm{a}$ & $\mathrm{n} / \mathrm{a}$ & $\mathrm{n} / \mathrm{a}$ & 75.0 & \\
\hline S11T011072 & Arsenic & $\mathrm{ug} / \mathrm{mL}$ & 100 & $\mathrm{n} / \mathrm{a}$ & $<125$ & $\mathrm{n} / \mathrm{a}$ & $\mathrm{n} / \mathrm{a}$ & $\mathrm{n} / \mathrm{a}$ & $\mathrm{n} / \mathrm{a}$ & 125 & \\
\hline S11T011072 & \begin{tabular}{|l|} 
Boron \\
\end{tabular} & $\mathrm{ug} / \mathrm{mL}$ & 99.2 & $\mathrm{n} / \mathrm{a}$ & $<75.0$ & $\mathrm{n} / \mathrm{a}$ & $\mathrm{n} / \mathrm{a}$ & $\mathrm{n} / \mathrm{a}$ & $\mathrm{n} / \mathrm{a}$ & 75.0 & \\
\hline S11T011072 & Barium & $\mathrm{ug} / \mathrm{mL}$ & 99.0 & $\mathrm{n} / \mathrm{a}$ & $<7.50$ & $\mathrm{n} / \mathrm{a}$ & $\mathrm{n} / \mathrm{a}$ & $\mathrm{n} / \mathrm{a}$ & $\mathrm{n} / \mathrm{a}$ & 7.50 & \\
\hline S11T011072 & Beryllium & $\mathrm{ug} / \mathrm{mL}$ & 97.5 & $\mathrm{n} / \mathrm{a}$ & $<2.50$ & $\mathrm{n} / \mathrm{a}$ & $\mathrm{n} / \mathrm{a}$ & $\mathrm{n} / \mathrm{a}$ & $\mathrm{n} / \mathrm{a}$ & 2.50 & \\
\hline S11T011072 & Bismuth & $\mathrm{ug} / \mathrm{mL}$ & 97.0 & $\mathrm{n} / \mathrm{a}$ & $<250$ & $\mathrm{n} / \mathrm{a}$ & $\mathrm{n} / \mathrm{a}$ & $\mathrm{n} / \mathrm{a}$ & $\mathrm{n} / \mathrm{a}$ & 250 & \\
\hline S11T011072 & Calcium & $\mathrm{ug} / \mathrm{mL}$ & 110 & $<0.0500$ & $<125$ & $\mathrm{n} / \mathrm{a}$ & $\mathrm{n} / \mathrm{a}$ & $\mathrm{n} / \mathrm{a}$ & $\mathrm{n} / \mathrm{a}$ & 125 & $\mathrm{U}$ \\
\hline S11T011072 & Cadmium & $\mathrm{ug} / \mathrm{mL}$ & 98.1 & $\mathrm{n} / \mathrm{a}$ & $<12.5$ & $\mathrm{n} / \mathrm{a}$ & $\mathrm{n} / \mathrm{a}$ & $\mathrm{n} / \mathrm{a}$ & $\mathrm{n} / \mathrm{a}$ & 12.5 & \\
\hline S11T011072 & Cerium & $\mathrm{ug} / \mathrm{mL}$ & 99.4 & $\mathrm{n} / \mathrm{a}$ & $<75.0$ & $\mathrm{n} / \mathrm{a}$ & $\mathrm{n} / \mathrm{a}$ & $\mathrm{n} / \mathrm{a}$ & $\mathrm{n} / \mathrm{a}$ & 75.0 & \\
\hline S11T011072 & Cobalt & $\mathrm{ug} / \mathrm{mL}$ & 98.1 & $\mathrm{n} / \mathrm{a}$ & $<25.0$ & $n / a$ & $\mathrm{n} / \mathrm{a}$ & $\mathrm{n} / \mathrm{a}$ & $\mathrm{n} / \mathrm{a}$ & 25.0 & \\
\hline S11T011072 & Chromium & $\mathrm{ug} / \mathrm{mL}$ & 98.1 & $<5.00 \mathrm{E}-03$ & 700 & $\mathrm{n} / \mathrm{a}$ & $\mathrm{n} / \mathrm{a}$ & $\mathrm{n} / \mathrm{a}$ & $\mathrm{n} / \mathrm{a}$ & 12.5 & \\
\hline S11T011072 & Copper & $\mathrm{ug} / \mathrm{mL}$ & 99.8 & $\mathrm{n} / \mathrm{a}$ & $<12.5$ & $\mathrm{n} / \mathrm{a}$ & $\mathrm{n} / \mathrm{a}$ & $\mathrm{n} / \mathrm{a}$ & $n / a$ & 12.5 & \\
\hline S11T011072 & Europium & $\mathrm{ug} / \mathrm{mL}$ & 94.3 & $\mathrm{n} / \mathrm{a}$ & $<12.5$ & $\mathrm{n} / \mathrm{a}$ & $\mathrm{n} / \mathrm{a}$ & $\mathrm{n} / \mathrm{a}$ & $\mathrm{n} / \mathrm{a}$ & 12.5 & \\
\hline S11T011072 & Iron & $\mathrm{ug} / \mathrm{mL}$ & 99.6 & $\mathrm{n} / \mathrm{a}$ & $<12.5$ & $\mathrm{n} / \mathrm{a}$ & $\mathrm{n} / \mathrm{a}$ & $\mathrm{n} / \mathrm{a}$ & $\mathrm{n} / \mathrm{a}$ & 12.5 & \\
\hline S11T011072 & Potassium & $\mathrm{ug} / \mathrm{mL}$ & 91.2 & $<0.500$ & $1.69 \mathrm{E}+03$ & $n / a$ & $\mathrm{n} / \mathrm{a}$ & $\mathrm{n} / \mathrm{a}$ & $n / a$ & $1.25 \mathrm{E}+03$ & $\mathrm{~J}$ \\
\hline S11T011072 & Lanthanum & $\mathrm{ug} / \mathrm{mL}$ & 99.2 & $\mathrm{n} / \mathrm{a}$ & $<7.50$ & $\mathrm{n} / \mathrm{a}$ & $\mathrm{n} / \mathrm{a}$ & $\mathrm{n} / \mathrm{a}$ & $\mathrm{n} / \mathrm{a}$ & 7.50 & \\
\hline
\end{tabular}


Table D-10. Centrifuged Liquid from Sample DIL 2. (2 sheets)

Sample Number(s): S11T011072 (Test Sample DIL 2)

Sample Group: 20111225

\begin{tabular}{|c|c|c|c|c|c|c|c|c|c|c|c|}
\hline Sample \# & Analyte & Unit & $\begin{array}{c}\text { Std } \\
\%-\operatorname{Rec}\end{array}$ & Blank & Result & Duplicate & Average & RPD & $\begin{array}{c}\text { Spk } \\
\text { \%-Rec }\end{array}$ & $\begin{array}{c}\text { Det } \\
\text { Limit }\end{array}$ & $\begin{array}{l}\text { Qual } \\
\text { Flags }\end{array}$ \\
\hline S11T011072 & Lithium & $\mathrm{ug} / \mathrm{mL}$ & 107 & $\mathrm{n} / \mathrm{a}$ & $<7.50$ & $\mathrm{n} / \mathrm{a}$ & $\mathrm{n} / \mathrm{a}$ & $\mathrm{n} / \mathrm{a}$ & $\mathrm{n} / \mathrm{a}$ & 7.50 & \\
\hline S11T011072 & Magnesium & $\mathrm{ug} / \mathrm{mL}$ & 99.5 & $\mathrm{n} / \mathrm{a}$ & $<125$ & $\mathrm{n} / \mathrm{a}$ & $\mathrm{n} / \mathrm{a}$ & $\mathrm{n} / \mathrm{a}$ & $\mathrm{n} / \mathrm{a}$ & 125 & \\
\hline S11T011072 & Manganese & $\mathrm{ug} / \mathrm{mL}$ & 96.4 & $\mathrm{n} / \mathrm{a}$ & $<7.50$ & $\mathrm{n} / \mathrm{a}$ & $\mathrm{n} / \mathrm{a}$ & $\mathrm{n} / \mathrm{a}$ & $\mathrm{n} / \mathrm{a}$ & 7.50 & \\
\hline S11T011072 & Molybdenum & $\mathrm{ug} / \mathrm{mL}$ & 98.4 & $\mathrm{n} / \mathrm{a}$ & $<50.0$ & $\mathrm{n} / \mathrm{a}$ & $\mathrm{n} / \mathrm{a}$ & $\mathrm{n} / \mathrm{a}$ & $\mathrm{n} / \mathrm{a}$ & 50.0 & \\
\hline S11T011072 & Sodium & $\mathrm{ug} / \mathrm{mL}$ & 107 & $<0.100$ & $1.30 \mathrm{E}+05$ & $\mathrm{n} / \mathrm{a}$ & $\mathrm{n} / \mathrm{a}$ & $\mathrm{n} / \mathrm{a}$ & $\mathrm{n} / \mathrm{a}$ & 250 & \\
\hline S11T011072 & Neodymium & $\mathrm{ug} / \mathrm{mL}$ & 97.4 & $\mathrm{n} / \mathrm{a}$ & $<25.0$ & $\mathrm{n} / \mathrm{a}$ & $\mathrm{n} / \mathrm{a}$ & $\mathrm{n} / \mathrm{a}$ & $\mathrm{n} / \mathrm{a}$ & 25.0 & \\
\hline S11T011072 & Nickel & $\mathrm{ug} / \mathrm{mL}$ & 97.3 & $\mathrm{n} / \mathrm{a}$ & $<50.0$ & $\mathrm{n} / \mathrm{a}$ & $\mathrm{n} / \mathrm{a}$ & $\mathrm{n} / \mathrm{a}$ & $\mathrm{n} / \mathrm{a}$ & 50.0 & \\
\hline S11T011072 & Phosphorus & $\mathrm{ug} / \mathrm{mL}$ & 99.1 & $<0.0500$ & $1.17 \mathrm{E}+03$ & $\mathrm{n} / \mathrm{a}$ & $\mathrm{n} / \mathrm{a}$ & $\mathrm{n} / \mathrm{a}$ & $\mathrm{n} / \mathrm{a}$ & 125 & $\mathrm{~J}$ \\
\hline S11T011072 & Lead & $\mathrm{ug} / \mathrm{mL}$ & 101 & $\mathrm{n} / \mathrm{a}$ & $<125$ & $\mathrm{n} / \mathrm{a}$ & $\mathrm{n} / \mathrm{a}$ & $\mathrm{n} / \mathrm{a}$ & $n / a$ & 125 & \\
\hline S11T011072 & Sulfur & $\mathrm{ug} / \mathrm{mL}$ & 99.2 & $<0.100$ & $3.76 \mathrm{E}+03$ & $\mathrm{n} / \mathrm{a}$ & $\mathrm{n} / \mathrm{a}$ & $\mathrm{n} / \mathrm{a}$ & $\mathrm{n} / \mathrm{a}$ & 250 & \\
\hline S11T011072 & Antimony & $\mathrm{ug} / \mathrm{mL}$ & 95.3 & $\mathrm{n} / \mathrm{a}$ & $<125$ & $\mathrm{n} / \mathrm{a}$ & $\mathrm{n} / \mathrm{a}$ & $\mathrm{n} / \mathrm{a}$ & $\mathrm{n} / \mathrm{a}$ & 125 & \\
\hline S11T011072 & Selenium & $\mathrm{ug} / \mathrm{mL}$ & 101 & $\mathrm{n} / \mathrm{a}$ & $<250$ & $\mathrm{n} / \mathrm{a}$ & $\mathrm{n} / \mathrm{a}$ & $\mathrm{n} / \mathrm{a}$ & $\mathrm{n} / \mathrm{a}$ & 250 & \\
\hline S11T011072 & Silicon & $\mathrm{ug} / \mathrm{mL}$ & 96.7 & $<0.0300$ & 211 & $\mathrm{n} / \mathrm{a}$ & $\mathrm{n} / \mathrm{a}$ & $\mathrm{n} / \mathrm{a}$ & $\mathrm{n} / \mathrm{a}$ & 75.0 & $\mathrm{~J}$ \\
\hline S11T011072 & Samarium & $\mathrm{ug} / \mathrm{mL}$ & 102 & $\mathrm{n} / \mathrm{a}$ & $<125$ & $\mathrm{n} / \mathrm{a}$ & $\mathrm{n} / \mathrm{a}$ & $\mathrm{n} / \mathrm{a}$ & $\mathrm{n} / \mathrm{a}$ & 125 & \\
\hline S11T011072 & Strontium & $\mathrm{ug} / \mathrm{mL}$ & 98.3 & $\mathrm{n} / \mathrm{a}$ & $<7.50$ & $\mathrm{n} / \mathrm{a}$ & $\mathrm{n} / \mathrm{a}$ & n/a & $\mathrm{n} / \mathrm{a}$ & 7.50 & \\
\hline S11T011072 & Thorium & $\mathrm{ug} / \mathrm{mL}$ & 97.3 & $\mathrm{n} / \mathrm{a}$ & $<125$ & $\mathrm{n} / \mathrm{a}$ & $\mathrm{n} / \mathrm{a}$ & $\mathrm{n} / \mathrm{a}$ & $\mathrm{n} / \mathrm{a}$ & 125 & \\
\hline S11T011072 & Titanium & $\mathrm{ug} / \mathrm{mL}$ & 96.6 & $\mathrm{n} / \mathrm{a}$ & $<12.5$ & $\mathrm{n} / \mathrm{a}$ & $\mathrm{n} / \mathrm{a}$ & $\mathrm{n} / \mathrm{a}$ & $\mathrm{n} / \mathrm{a}$ & 12.5 & \\
\hline S11T011072 & Thallium & $\mathrm{ug} / \mathrm{mL}$ & 97.3 & $\mathrm{n} / \mathrm{a}$ & $<250$ & $\mathrm{n} / \mathrm{a}$ & $\mathrm{n} / \mathrm{a}$ & $\mathrm{n} / \mathrm{a}$ & $\mathrm{n} / \mathrm{a}$ & 250 & \\
\hline S11T011072 & Uranium & $\mathrm{ug} / \mathrm{mL}$ & 99.5 & $\mathrm{n} / \mathrm{a}$ & $<250$ & $n / a$ & $\mathrm{n} / \mathrm{a}$ & $\mathrm{n} / \mathrm{a}$ & $\mathrm{n} / \mathrm{a}$ & 250 & \\
\hline S11T011072 & Vanadium & $\mathrm{ug} / \mathrm{mL}$ & 98.8 & $\mathrm{n} / \mathrm{a}$ & $<12.5$ & $\mathrm{n} / \mathrm{a}$ & $\mathrm{n} / \mathrm{a}$ & $\mathrm{n} / \mathrm{a}$ & $\mathrm{n} / \mathrm{a}$ & 12.5 & \\
\hline S11T011072 & Yttrium & $\mathrm{ug} / \mathrm{mL}$ & 94.7 & $\mathrm{n} / \mathrm{a}$ & $<5.00$ & $\mathrm{n} / \mathrm{a}$ & $\mathrm{n} / \mathrm{a}$ & $\mathrm{n} / \mathrm{a}$ & $\mathrm{n} / \mathrm{a}$ & 5.00 & \\
\hline S11T011072 & Zinc & $\mathrm{ug} / \mathrm{mL}$ & 96.6 & $\mathrm{n} / \mathrm{a}$ & $<12.5$ & $\mathrm{n} / \mathrm{a}$ & $\mathrm{n} / \mathrm{a}$ & $\mathrm{n} / \mathrm{a}$ & $\mathrm{n} / \mathrm{a}$ & 12.5 & \\
\hline S11T011072 & Zirconium & $\mathrm{ug} / \mathrm{mL}$ & 98.7 & $\mathrm{n} / \mathrm{a}$ & $<12.5$ & $\mathrm{n} / \mathrm{a}$ & $\mathrm{n} / \mathrm{a}$ & $\mathrm{n} / \mathrm{a}$ & $\mathrm{n} / \mathrm{a}$ & 12.5 & \\
\hline S11T011072 & Hydroxide & $\mathrm{ug} / \mathrm{mL}$ & 105 & $<41.7$ & $1.2 \mathrm{E}+04$ & $\mathrm{n} / \mathrm{a}$ & $\mathrm{n} / \mathrm{a}$ & $\mathrm{n} / \mathrm{a}$ & $\mathrm{n} / \mathrm{a}$ & 550 & \\
\hline S11T011072 & Specific gravity & unitless & 100.5 & $\mathrm{n} / \mathrm{a}$ & 1.299 & $\mathrm{n} / \mathrm{a}$ & $\mathrm{n} / \mathrm{a}$ & $\mathrm{n} / \mathrm{a}$ & $\mathrm{n} / \mathrm{a}$ & $1.00 \mathrm{E}-03$ & \\
\hline S11T011072 & Total organic carbon & $\mathrm{ug} / \mathrm{mL}$ & 96.5 & $<20.0$ & 925 & $\mathrm{n} / \mathrm{a}$ & $\mathrm{n} / \mathrm{a}$ & $\mathrm{n} / \mathrm{a}$ & $\mathrm{n} / \mathrm{a}$ & 200 & $\mathrm{~J}$ \\
\hline S11T011072 & Total inorganic carbon & $\mathrm{ug} / \mathrm{mL}$ & 98.7 & $<7.00$ & $6.24 \mathrm{E}+03$ & $\mathrm{n} / \mathrm{a}$ & $\mathrm{n} / \mathrm{a}$ & $\mathrm{n} / \mathrm{a}$ & $\mathrm{n} / \mathrm{a}$ & 7.00 & \\
\hline
\end{tabular}


Table D-11. Centrifuged Liquid from Sample DIL 3. (2 sheets)

Sample Number(s): S11T011073 (Test Sample DIL 3)

Sample Group: 20111225

\begin{tabular}{|c|c|c|c|c|c|c|c|c|c|c|c|}
\hline Sample \# & Analyte & Unit & $\begin{array}{c}\text { Std } \\
\%-\operatorname{Rec}\end{array}$ & Blank & Result & Duplicate & Average & RPD & $\begin{array}{c}\text { Spk } \\
\% \text {-Rec }\end{array}$ & $\begin{array}{c}\text { Det } \\
\text { Limit }\end{array}$ & $\begin{array}{l}\text { Qual } \\
\text { Flags }\end{array}$ \\
\hline S11T011073 & Fluoride & $\mathrm{ug} / \mathrm{mL}$ & 103 & $<1.61 \mathrm{E}-03$ & 513 & $\mathrm{n} / \mathrm{a}$ & $\mathrm{n} / \mathrm{a}$ & $\mathrm{n} / \mathrm{a}$ & $\mathrm{n} / \mathrm{a}$ & 1.61 & \\
\hline S11T011073 & Glycolate & $\mathrm{ug} / \mathrm{mL}$ & 98.8 & $<9.37 \mathrm{E}-03$ & 194 & $\mathrm{n} / \mathrm{a}$ & $\mathrm{n} / \mathrm{a}$ & $\mathrm{n} / \mathrm{a}$ & $\mathrm{n} / \mathrm{a}$ & 9.37 & \\
\hline S11T011073 & Acetate & $\mathrm{ug} / \mathrm{mL}$ & 97.0 & $<6.04 \mathrm{E}-03$ & 221 & $\mathrm{n} / \mathrm{a}$ & $\mathrm{n} / \mathrm{a}$ & $\mathrm{n} / \mathrm{a}$ & $\mathrm{n} / \mathrm{a}$ & 6.04 & \\
\hline S11T011073 & Formate & $\mathrm{ug} / \mathrm{mL}$ & 99.7 & $<4.67 \mathrm{E}-03$ & 700 & $\mathrm{n} / \mathrm{a}$ & $\mathrm{n} / \mathrm{a}$ & $\mathrm{n} / \mathrm{a}$ & $\mathrm{n} / \mathrm{a}$ & 4.67 & \\
\hline S11T011073 & Chloride & $\mathrm{ug} / \mathrm{mL}$ & 99.3 & 0.0132 & $1.52 \mathrm{E}+03$ & $\mathrm{n} / \mathrm{a}$ & $\mathrm{n} / \mathrm{a}$ & $\mathrm{n} / \mathrm{a}$ & $\mathrm{n} / \mathrm{a}$ & 9.98 & \\
\hline S11T011073 & Nitrite & $\mathrm{ug} / \mathrm{mL}$ & 101 & $<0.0192$ & $3.31 \mathrm{E}+04$ & $\mathrm{n} / \mathrm{a}$ & $\mathrm{n} / \mathrm{a}$ & $\mathrm{n} / \mathrm{a}$ & $\mathrm{n} / \mathrm{a}$ & 96.0 & \\
\hline S11T011073 & Sulfate & $\mathrm{ug} / \mathrm{mL}$ & 102 & $<0.0187$ & $9.89 \mathrm{E}+03$ & $\mathrm{n} / \mathrm{a}$ & $\mathrm{n} / \mathrm{a}$ & $\mathrm{n} / \mathrm{a}$ & $\mathrm{n} / \mathrm{a}$ & 18.7 & \\
\hline S11T011073 & Oxalate & $\mathrm{ug} / \mathrm{mL}$ & 102 & $<0.0231$ & $1.24 \mathrm{E}+03$ & $\mathrm{n} / \mathrm{a}$ & $\mathrm{n} / \mathrm{a}$ & $\mathrm{n} / \mathrm{a}$ & $\mathrm{n} / \mathrm{a}$ & 23.1 & \\
\hline S11T011073 & Bromide & $\mathrm{ug} / \mathrm{mL}$ & 101 & $<0.0580$ & $<58.0$ & $\mathrm{n} / \mathrm{a}$ & $\mathrm{n} / \mathrm{a}$ & $\mathrm{n} / \mathrm{a}$ & $\mathrm{n} / \mathrm{a}$ & 58.0 & $\mathrm{U}$ \\
\hline S11T011073 & Nitrate & $\mathrm{ug} / \mathrm{mL}$ & 101 & 0.0715 & $1.29 \mathrm{E}+05$ & $\mathrm{n} / \mathrm{a}$ & $\mathrm{n} / \mathrm{a}$ & $\mathrm{n} / \mathrm{a}$ & $\mathrm{n} / \mathrm{a}$ & 208 & \\
\hline S11T011073 & Phosphate & $\mathrm{ug} / \mathrm{mL}$ & 101 & $<0.0167$ & $3.19 \mathrm{E}+03$ & $\mathrm{n} / \mathrm{a}$ & $\mathrm{n} / \mathrm{a}$ & $\mathrm{n} / \mathrm{a}$ & $\mathrm{n} / \mathrm{a}$ & 16.7 & \\
\hline S11T011073 & \begin{tabular}{|l|} 
Silver \\
\end{tabular} & $\mathrm{ug} / \mathrm{mL}$ & 97.6 & $\mathrm{n} / \mathrm{a}$ & $<12.5$ & $\mathrm{n} / \mathrm{a}$ & $\mathrm{n} / \mathrm{a}$ & $\mathrm{n} / \mathrm{a}$ & $\mathrm{n} / \mathrm{a}$ & 12.5 & \\
\hline S11T011073 & Aluminum & $\mathrm{ug} / \mathrm{mL}$ & 100 & $<0.0300$ & $5.76 \mathrm{E}+03$ & $\mathrm{n} / \mathrm{a}$ & $\mathrm{n} / \mathrm{a}$ & $\mathrm{n} / \mathrm{a}$ & $\mathrm{n} / \mathrm{a}$ & 75.0 & \\
\hline S11T011073 & Arsenic & $\mathrm{ug} / \mathrm{mL}$ & 100 & $\mathrm{n} / \mathrm{a}$ & $<125$ & $\mathrm{n} / \mathrm{a}$ & $\mathrm{n} / \mathrm{a}$ & $\mathrm{n} / \mathrm{a}$ & $\mathrm{n} / \mathrm{a}$ & 125 & \\
\hline S11T011073 & \begin{tabular}{|l|} 
Boron \\
\end{tabular} & $\mathrm{ug} / \mathrm{mL}$ & 99.2 & $\mathrm{n} / \mathrm{a}$ & $<75.0$ & $\mathrm{n} / \mathrm{a}$ & $\mathrm{n} / \mathrm{a}$ & $\mathrm{n} / \mathrm{a}$ & $\mathrm{n} / \mathrm{a}$ & 75.0 & \\
\hline S11T011073 & Barium & $\mathrm{ug} / \mathrm{mL}$ & 99.0 & $\mathrm{n} / \mathrm{a}$ & $<7.50$ & $\mathrm{n} / \mathrm{a}$ & $\mathrm{n} / \mathrm{a}$ & $\mathrm{n} / \mathrm{a}$ & $\mathrm{n} / \mathrm{a}$ & 7.50 & \\
\hline S11T011073 & Beryllium & $\mathrm{ug} / \mathrm{mL}$ & 97.5 & $\mathrm{n} / \mathrm{a}$ & $<2.50$ & $\mathrm{n} / \mathrm{a}$ & $\mathrm{n} / \mathrm{a}$ & $\mathrm{n} / \mathrm{a}$ & $\mathrm{n} / \mathrm{a}$ & 2.50 & \\
\hline S11T011073 & Bismuth & $\mathrm{ug} / \mathrm{mL}$ & 97.0 & $\mathrm{n} / \mathrm{a}$ & $<250$ & $\mathrm{n} / \mathrm{a}$ & $\mathrm{n} / \mathrm{a}$ & $\mathrm{n} / \mathrm{a}$ & $\mathrm{n} / \mathrm{a}$ & 250 & \\
\hline S11T011073 & Calcium & $\mathrm{ug} / \mathrm{mL}$ & 110 & $<0.0500$ & $<125$ & $\mathrm{n} / \mathrm{a}$ & $\mathrm{n} / \mathrm{a}$ & $\mathrm{n} / \mathrm{a}$ & $\mathrm{n} / \mathrm{a}$ & 125 & $\mathrm{U}$ \\
\hline S11T011073 & Cadmium & $\mathrm{ug} / \mathrm{mL}$ & 98.1 & $\mathrm{n} / \mathrm{a}$ & $<12.5$ & $\mathrm{n} / \mathrm{a}$ & $\mathrm{n} / \mathrm{a}$ & $\mathrm{n} / \mathrm{a}$ & $\mathrm{n} / \mathrm{a}$ & 12.5 & \\
\hline S11T011073 & Cerium & $\mathrm{ug} / \mathrm{mL}$ & 99.4 & $\mathrm{n} / \mathrm{a}$ & $<75.0$ & $\mathrm{n} / \mathrm{a}$ & $\mathrm{n} / \mathrm{a}$ & $\mathrm{n} / \mathrm{a}$ & $\mathrm{n} / \mathrm{a}$ & 75.0 & \\
\hline S11T011073 & Cobalt & $\mathrm{ug} / \mathrm{mL}$ & 98.1 & $\mathrm{n} / \mathrm{a}$ & 26.2 & $n / a$ & $\mathrm{n} / \mathrm{a}$ & $\mathrm{n} / \mathrm{a}$ & $\mathrm{n} / \mathrm{a}$ & 25.0 & \\
\hline S11T011073 & Chromium & $\mathrm{ug} / \mathrm{mL}$ & 98.1 & $<5.00 \mathrm{E}-03$ & 758 & $\mathrm{n} / \mathrm{a}$ & $\mathrm{n} / \mathrm{a}$ & $\mathrm{n} / \mathrm{a}$ & $\mathrm{n} / \mathrm{a}$ & 12.5 & \\
\hline S11T011073 & Copper & $\mathrm{ug} / \mathrm{mL}$ & 99.8 & $\mathrm{n} / \mathrm{a}$ & $<12.5$ & $\mathrm{n} / \mathrm{a}$ & $\mathrm{n} / \mathrm{a}$ & $\mathrm{n} / \mathrm{a}$ & $n / a$ & 12.5 & \\
\hline S11T011073 & Europium & $\mathrm{ug} / \mathrm{mL}$ & 94.3 & $\mathrm{n} / \mathrm{a}$ & $<12.5$ & $\mathrm{n} / \mathrm{a}$ & $\mathrm{n} / \mathrm{a}$ & $\mathrm{n} / \mathrm{a}$ & $\mathrm{n} / \mathrm{a}$ & 12.5 & \\
\hline S11T011073 & Iron & $\mathrm{ug} / \mathrm{mL}$ & 99.6 & $\mathrm{n} / \mathrm{a}$ & $<12.5$ & $\mathrm{n} / \mathrm{a}$ & $\mathrm{n} / \mathrm{a}$ & $\mathrm{n} / \mathrm{a}$ & $\mathrm{n} / \mathrm{a}$ & 12.5 & \\
\hline S11T011073 & Potassium & $\mathrm{ug} / \mathrm{mL}$ & 91.2 & $<0.500$ & $2.32 \mathrm{E}+03$ & $n / a$ & $\mathrm{n} / \mathrm{a}$ & $\mathrm{n} / \mathrm{a}$ & $n / a$ & $1.25 \mathrm{E}+03$ & $\mathrm{~J}$ \\
\hline S11T011073 & Lanthanum & $\mathrm{ug} / \mathrm{mL}$ & 99.2 & $\mathrm{n} / \mathrm{a}$ & $<7.50$ & $\mathrm{n} / \mathrm{a}$ & $\mathrm{n} / \mathrm{a}$ & $\mathrm{n} / \mathrm{a}$ & $\mathrm{n} / \mathrm{a}$ & 7.50 & \\
\hline
\end{tabular}


Table D-11. Centrifuged Liquid from Sample DIL 3. (2 sheets)

Sample Number(s): S11T011073 (Test Sample DIL 3)

Sample Group: 20111225

\begin{tabular}{|c|c|c|c|c|c|c|c|c|c|c|c|}
\hline Sample \# & Analyte & Unit & $\begin{array}{c}\text { Std } \\
\%-\operatorname{Rec}\end{array}$ & Blank & Result & Duplicate & Average & RPD & $\begin{array}{c}\text { Spk } \\
\% \text {-Rec }\end{array}$ & $\begin{array}{c}\text { Det } \\
\text { Limit }\end{array}$ & $\begin{array}{l}\text { Qual } \\
\text { Flags }\end{array}$ \\
\hline S11T011073 & Lithium & $\mathrm{ug} / \mathrm{mL}$ & 107 & $\mathrm{n} / \mathrm{a}$ & $<7.50$ & $\mathrm{n} / \mathrm{a}$ & $\mathrm{n} / \mathrm{a}$ & $\mathrm{n} / \mathrm{a}$ & $\mathrm{n} / \mathrm{a}$ & 7.50 & \\
\hline S11T011073 & Magnesium & $\mathrm{ug} / \mathrm{mL}$ & 99.5 & $\mathrm{n} / \mathrm{a}$ & $<125$ & $\mathrm{n} / \mathrm{a}$ & $\mathrm{n} / \mathrm{a}$ & $\mathrm{n} / \mathrm{a}$ & $\mathrm{n} / \mathrm{a}$ & 125 & \\
\hline S11T011073 & Manganese & $\mathrm{ug} / \mathrm{mL}$ & 96.4 & $\mathrm{n} / \mathrm{a}$ & $<7.50$ & $\mathrm{n} / \mathrm{a}$ & $\mathrm{n} / \mathrm{a}$ & $\mathrm{n} / \mathrm{a}$ & $\mathrm{n} / \mathrm{a}$ & 7.50 & \\
\hline S11T011073 & Molybdenum & $\mathrm{ug} / \mathrm{mL}$ & 98.4 & $\mathrm{n} / \mathrm{a}$ & $<50.0$ & $\mathrm{n} / \mathrm{a}$ & $\mathrm{n} / \mathrm{a}$ & $\mathrm{n} / \mathrm{a}$ & $\mathrm{n} / \mathrm{a}$ & 50.0 & \\
\hline S11T011073 & Sodium & $\mathrm{ug} / \mathrm{mL}$ & 107 & $<0.100$ & $1.40 \mathrm{E}+05$ & $\mathrm{n} / \mathrm{a}$ & $\mathrm{n} / \mathrm{a}$ & $\mathrm{n} / \mathrm{a}$ & $\mathrm{n} / \mathrm{a}$ & 250 & \\
\hline S11T011073 & Neodymium & $\mathrm{ug} / \mathrm{mL}$ & 97.4 & $\mathrm{n} / \mathrm{a}$ & $<25.0$ & $\mathrm{n} / \mathrm{a}$ & $\mathrm{n} / \mathrm{a}$ & $\mathrm{n} / \mathrm{a}$ & $\mathrm{n} / \mathrm{a}$ & 25.0 & \\
\hline S11T011073 & Nickel & $\mathrm{ug} / \mathrm{mL}$ & 97.3 & $\mathrm{n} / \mathrm{a}$ & $<50.0$ & $\mathrm{n} / \mathrm{a}$ & $\mathrm{n} / \mathrm{a}$ & $\mathrm{n} / \mathrm{a}$ & $\mathrm{n} / \mathrm{a}$ & 50.0 & \\
\hline S11T011073 & Phosphorus & $\mathrm{ug} / \mathrm{mL}$ & 99.1 & $<0.0500$ & $1.29 \mathrm{E}+03$ & $\mathrm{n} / \mathrm{a}$ & $\mathrm{n} / \mathrm{a}$ & $\mathrm{n} / \mathrm{a}$ & $\mathrm{n} / \mathrm{a}$ & 125 & \\
\hline S11T011073 & Lead & $\mathrm{ug} / \mathrm{mL}$ & 101 & $\mathrm{n} / \mathrm{a}$ & $<125$ & $\mathrm{n} / \mathrm{a}$ & $\mathrm{n} / \mathrm{a}$ & $\mathrm{n} / \mathrm{a}$ & $\mathrm{n} / \mathrm{a}$ & 125 & \\
\hline S11T011073 & Sulfur & $\mathrm{ug} / \mathrm{mL}$ & 99.2 & $<0.100$ & $4.00 \mathrm{E}+03$ & $\mathrm{n} / \mathrm{a}$ & $\mathrm{n} / \mathrm{a}$ & $\mathrm{n} / \mathrm{a}$ & $\mathrm{n} / \mathrm{a}$ & 250 & \\
\hline S11T011073 & Antimony & $\mathrm{ug} / \mathrm{mL}$ & 95.3 & $\mathrm{n} / \mathrm{a}$ & $<125$ & $\mathrm{n} / \mathrm{a}$ & $\mathrm{n} / \mathrm{a}$ & $\mathrm{n} / \mathrm{a}$ & $\mathrm{n} / \mathrm{a}$ & 125 & \\
\hline S11T011073 & Selenium & $\mathrm{ug} / \mathrm{mL}$ & 101 & $\mathrm{n} / \mathrm{a}$ & $<250$ & $\mathrm{n} / \mathrm{a}$ & $\mathrm{n} / \mathrm{a}$ & $\mathrm{n} / \mathrm{a}$ & $\mathrm{n} / \mathrm{a}$ & 250 & \\
\hline S11T011073 & Silicon & $\mathrm{ug} / \mathrm{mL}$ & 96.7 & $<0.0300$ & 198 & $\mathrm{n} / \mathrm{a}$ & $\mathrm{n} / \mathrm{a}$ & $\mathrm{n} / \mathrm{a}$ & $\mathrm{n} / \mathrm{a}$ & 75.0 & $\mathrm{~J}$ \\
\hline S11T011073 & Samarium & $\mathrm{ug} / \mathrm{mL}$ & 102 & $\mathrm{n} / \mathrm{a}$ & $<125$ & $\mathrm{n} / \mathrm{a}$ & $\mathrm{n} / \mathrm{a}$ & $\mathrm{n} / \mathrm{a}$ & $\mathrm{n} / \mathrm{a}$ & 125 & \\
\hline S11T011073 & \begin{tabular}{|l|} 
Strontium \\
\end{tabular} & $\mathrm{ug} / \mathrm{mL}$ & 98.3 & $\mathrm{n} / \mathrm{a}$ & $<7.50$ & $\mathrm{n} / \mathrm{a}$ & $\mathrm{n} / \mathrm{a}$ & $\mathrm{n} / \mathrm{a}$ & $\mathrm{n} / \mathrm{a}$ & 7.50 & \\
\hline S11T011073 & Thorium & $\mathrm{ug} / \mathrm{mL}$ & 97.3 & $\mathrm{n} / \mathrm{a}$ & $<125$ & $\mathrm{n} / \mathrm{a}$ & $\mathrm{n} / \mathrm{a}$ & $\mathrm{n} / \mathrm{a}$ & $\mathrm{n} / \mathrm{a}$ & 125 & \\
\hline S11T011073 & Titanium & $\mathrm{ug} / \mathrm{mL}$ & 96.6 & $\mathrm{n} / \mathrm{a}$ & $<12.5$ & $\mathrm{n} / \mathrm{a}$ & $\mathrm{n} / \mathrm{a}$ & $\mathrm{n} / \mathrm{a}$ & $\mathrm{n} / \mathrm{a}$ & 12.5 & \\
\hline S11T011073 & Thallium & $\mathrm{ug} / \mathrm{mL}$ & 97.3 & $\mathrm{n} / \mathrm{a}$ & $<250$ & $\mathrm{n} / \mathrm{a}$ & $\mathrm{n} / \mathrm{a}$ & $\mathrm{n} / \mathrm{a}$ & $\mathrm{n} / \mathrm{a}$ & 250 & \\
\hline S11T011073 & Uranium & $\mathrm{ug} / \mathrm{mL}$ & 99.5 & $\mathrm{n} / \mathrm{a}$ & $<250$ & $\mathrm{n} / \mathrm{a}$ & $\mathrm{n} / \mathrm{a}$ & $\mathrm{n} / \mathrm{a}$ & $\mathrm{n} / \mathrm{a}$ & 250 & \\
\hline S11T011073 & Vanadium & $\mathrm{ug} / \mathrm{mL}$ & 98.8 & $\mathrm{n} / \mathrm{a}$ & $<12.5$ & $\mathrm{n} / \mathrm{a}$ & $\mathrm{n} / \mathrm{a}$ & $\mathrm{n} / \mathrm{a}$ & $\mathrm{n} / \mathrm{a}$ & 12.5 & \\
\hline S11T011073 & Yttrium & $\mathrm{ug} / \mathrm{mL}$ & 94.7 & $\mathrm{n} / \mathrm{a}$ & $<5.00$ & $\mathrm{n} / \mathrm{a}$ & $\mathrm{n} / \mathrm{a}$ & $\mathrm{n} / \mathrm{a}$ & $\mathrm{n} / \mathrm{a}$ & 5.00 & \\
\hline S11T011073 & Zinc & $\mathrm{ug} / \mathrm{mL}$ & 96.6 & $\mathrm{n} / \mathrm{a}$ & $<12.5$ & $n / a$ & $\mathrm{n} / \mathrm{a}$ & $\mathrm{n} / \mathrm{a}$ & $\mathrm{n} / \mathrm{a}$ & 12.5 & \\
\hline S11T011073 & Zirconium & $\mathrm{ug} / \mathrm{mL}$ & 98.7 & $\mathrm{n} / \mathrm{a}$ & $<12.5$ & $\mathrm{n} / \mathrm{a}$ & $\mathrm{n} / \mathrm{a}$ & $\mathrm{n} / \mathrm{a}$ & $\mathrm{n} / \mathrm{a}$ & 12.5 & \\
\hline S11T011073 & Hydroxide & $\mathrm{ug} / \mathrm{mL}$ & 105 & $<41.7$ & $1.1 \mathrm{E}+04$ & $\mathrm{n} / \mathrm{a}$ & $\mathrm{n} / \mathrm{a}$ & $\mathrm{n} / \mathrm{a}$ & $\mathrm{n} / \mathrm{a}$ & 550 & \\
\hline S11T011073 & Specific gravity & unitless & 100.5 & $\mathrm{n} / \mathrm{a}$ & 1.259 & $\mathrm{n} / \mathrm{a}$ & $\mathrm{n} / \mathrm{a}$ & $\mathrm{n} / \mathrm{a}$ & $\mathrm{n} / \mathrm{a}$ & $1.00 \mathrm{E}-03$ & \\
\hline S11T011073 & Total organic carbon & $\mathrm{ug} / \mathrm{mL}$ & 96.5 & $<20.0$ & 407 & $\mathrm{n} / \mathrm{a}$ & $\mathrm{n} / \mathrm{a}$ & $\mathrm{n} / \mathrm{a}$ & $\mathrm{n} / \mathrm{a}$ & 200 & $\mathrm{~J}$ \\
\hline S11T011073 & Total inorganic carbon & $\mathrm{ug} / \mathrm{mL}$ & 98.7 & $<7.00$ & $5.98 \mathrm{E}+03$ & $\mathrm{n} / \mathrm{a}$ & $\mathrm{n} / \mathrm{a}$ & $\mathrm{n} / \mathrm{a}$ & $\mathrm{n} / \mathrm{a}$ & 7.00 & \\
\hline S11T011073 & Total carbon & $\mathrm{ug} / \mathrm{mL}$ & 97.2 & $<5.00$ & $7.54 \mathrm{E}+03$ & $\mathrm{n} / \mathrm{a}$ & $\mathrm{n} / \mathrm{a}$ & $\mathrm{n} / \mathrm{a}$ & $\mathrm{n} / \mathrm{a}$ & 55.0 & \\
\hline
\end{tabular}


LAB-RPT-12-00008, R0

ATTACHMENT E

SOLID PHASE CHARACTERIZATION OF BOILDOWN SOLIDS 


\section{ATTACHMENT E SOLID PHASE CHARACTERIZATION OF BOILDOWN SOLIDS}

Five samples of centrifuged solids (C-Slds) recovered from tank 241-AP-107 boildown samples were submitted (October 18, 2011) for solid phase characterization (SPC) to identify solid phases present.

\begin{tabular}{|c|c|}
\hline Sample Number & Solids \\
\hline S11T014140 & $\begin{array}{l}\text { Composite of C-Slds recovered from Samples CON } 1\left(27.7 \% \mathrm{WVR}^{18^{\circ} \mathrm{C}}\right) \text {, } \\
\text { CON } 2\left(36.9 \% \mathrm{WVR}^{18^{\circ} \mathrm{C}}\right) \text {, and CON } 3\left(41.6 \% \mathrm{WVR}^{18^{\circ} \mathrm{C}}\right)\end{array}$ \\
\hline S11T014141 & $\begin{array}{l}\text { Composite of C-Slds recovered from Samples CON } 4\left(46.1 \% \mathrm{WVR}^{18^{\circ} \mathrm{C}}\right) \text { and } \\
\text { CON } 5\left(50.2 \% \mathrm{WVR}^{18^{\circ} \mathrm{C}}\right)\end{array}$ \\
\hline S11T014280 & C-Slds recovered from boildown Sample CON $6\left(54.0 \% \mathrm{WVR}^{18^{\circ} \mathrm{C}}\right)$ \\
\hline S11T011074 & $\mathrm{C}-\mathrm{Slds}$ recovered from the end-point slurry Sample CON $7\left(57.5 \% \mathrm{WVR}{ }^{18^{\circ} \mathrm{C}}\right)$ \\
\hline S11T011075 & Solids remaining after final dilution Step DIL $3\left(8.4 \% \mathrm{WVR}^{18^{\circ} \mathrm{C}}\right)$ \\
\hline
\end{tabular}

All 5 samples were submitted in 25-mL glass vials and contained white, fine-grained solids covered with a 2-5 mm layer of clear, yellow supernatant liquid.

Three analysis methods were used: polarized light microscopy (PLM), powder X-ray diffraction (XRD), and scanning electron microscopy with energy-dispersive X-ray spectrometry (SEM/EDX). The SPC analyses were performed by members of the 222-S Special Analytical Services and Process Chemistry groups under the following procedures:

$\begin{array}{ll}\text { ATS-LT-519-107 } & \text { 222-S Laboratory Polarized Light Microscopy } \\ \text { ATS-LT-507-101 } & \text { 222-S Laboratory X-Ray Diffractometry (XRD) } \\ \text { ATS-LT-161-100 } & \begin{array}{l}\text { 222-S Laboratory Sample Preparation and Operating } \\ \text { Procedure for Scanning Electron Microscopes }\end{array}\end{array}$

Each of the SPC methods is limited to examination of very small quantities of solids. Homogenization and subsampling of radiologically "hot" samples to collect representative specimens of the required weight/volume is difficult at best. Nevertheless, a single specimen was prepared and analyzed for each method. Also, specimens for XRD and SEM/EDX analyses must be dried during preparation, and solids dissolved in the liquids collected with the samples may precipitate and complicate interpretation of analysis results. For these reasons, the results of the SPC analyses are qualitative to semiquantitative in nature.

\section{SEM/EDX Specimen Preparation and Analysis}

Due to the high solubility of the solids, specimens for SEM/EDX analysis were prepared using the supernatant liquid in each sample to help disperse the particulates. This was accomplished by placing a $37-\mathrm{mm}$ diameter cellulose backing pad and a $0.45-\mu \mathrm{m}$ pore size, Nucleopore polycarbonate filter on the fritted glass base of a filtration flask connected to a trap and house 
vacuum. A filtration funnel was then placed on the filter stack and clamped into place. For each sample, approximately 2 to $3 \mathrm{~mL}$ of the supernatant liquid was applied to the top of the filter, with the vacuum turned off, using a disposable plastic pipette. Using the same pipette, a small portion of the sample solids were then transferred to the liquid on the filter. The vacuum apparatus was then quickly and gently shaken to help disperse the solids across the filter surface, and the vacuum pump was immediately turned on. When the fluid had drained from the filter surface, the clamp and funnel were removed, and the filter was allowed to completely dry. A section of the filter was cut out and affixed to a carbon planchet (attached to an aluminum SEM stub) using carbon paint. The resulting SEM specimens were then coated with a conductive coating of carbon by evaporative deposition.

Analysis by SEM was conducted using an Aspex ${ }^{\circledR}{ }^{5}$ Personal Scanning Electron Microscope Model II, with a Noran light element EDX spectrometer for chemical analysis. The instrument was operated at an accelerating voltage of $20 \mathrm{kV}$, and the samples were mounted at a working distance of 15 to $20 \mathrm{~mm}$. All images were acquired in secondary electron imaging mode. The EDX spectra were acquired for 30 seconds live time (unless noted) on relatively smooth surfaces (either flat or sloping toward the detector) near the center of the images.

\footnotetext{
${ }^{5}$ Aspex is a registered trademark of ASPEX Instruments, Delmont, Pennsylvania.
} 


\section{Sample S11T014140: Composite of Solids from Boildown Samples CON $1\left(27.7 \% \mathrm{WVR}^{18{ }^{\circ} \mathrm{C}}\right)$ through CON $3\left(41.6 \% \mathrm{WVR}^{18{ }^{\circ} \mathrm{C}}\right)$}

\section{XRD Results}

The major solid phases identified were natroxalate $\left(\mathrm{Na}_{2} \mathrm{C}_{2} \mathrm{O}_{4}\right)$ and natrophosphate $\left[\mathrm{Na} 7 \mathrm{~F}\left(\mathrm{PO}_{4}\right)_{2} \cdot 19 \mathrm{H}_{2} \mathrm{O}\right]$. Nitratine $\left(\mathrm{NaNO}_{3}\right)$ was identified as a major phase and sodium nitrite $\left(\mathrm{NaNO}_{2}\right)$ as a minor phase of the sample; both are speculated to have crystallized from the interstitial liquid when the sample was dried. Thermonatrite $\left(\mathrm{Na}_{2} \mathrm{CO}_{3} \cdot \mathrm{H}_{2} \mathrm{O}\right)$ and kogarkoite $\left(\mathrm{Na}_{3} \mathrm{FSO}_{4}\right)$ were identified as minor phases of the sample.

Chemical Name

Sodium Oxalate

Sodium Fluoride Phosphate Hydrate

Sodium Nitrate

Sodium Nitrite

Sodium Carbonate Hydrate

Sodium Fluoride Sulfate
Mineral Name

Natroxalate

Natrophosphate

Nitratine

$---$

Thermonatrite

Kogarkoite
Formula

$\mathrm{Na}_{2} \mathrm{C}_{2} \mathrm{O}_{4}$

$\mathrm{Na}_{7} \mathrm{~F}\left(\mathrm{PO}_{4}\right)_{2} \bullet 19 \mathrm{H}_{2} \mathrm{O}$

$\mathrm{NaNO}_{3}$

$\mathrm{NaNO}_{2}$

$\mathrm{Na}_{2} \mathrm{CO}_{3} \cdot \mathrm{H}_{2} \mathrm{O}$

$\mathrm{Na}_{3} \mathrm{FSO}_{4}$
Relative Amount

Major

Major

Major

Minor

Minor

Minor

Figure XRD-1. Sample S11T014140.

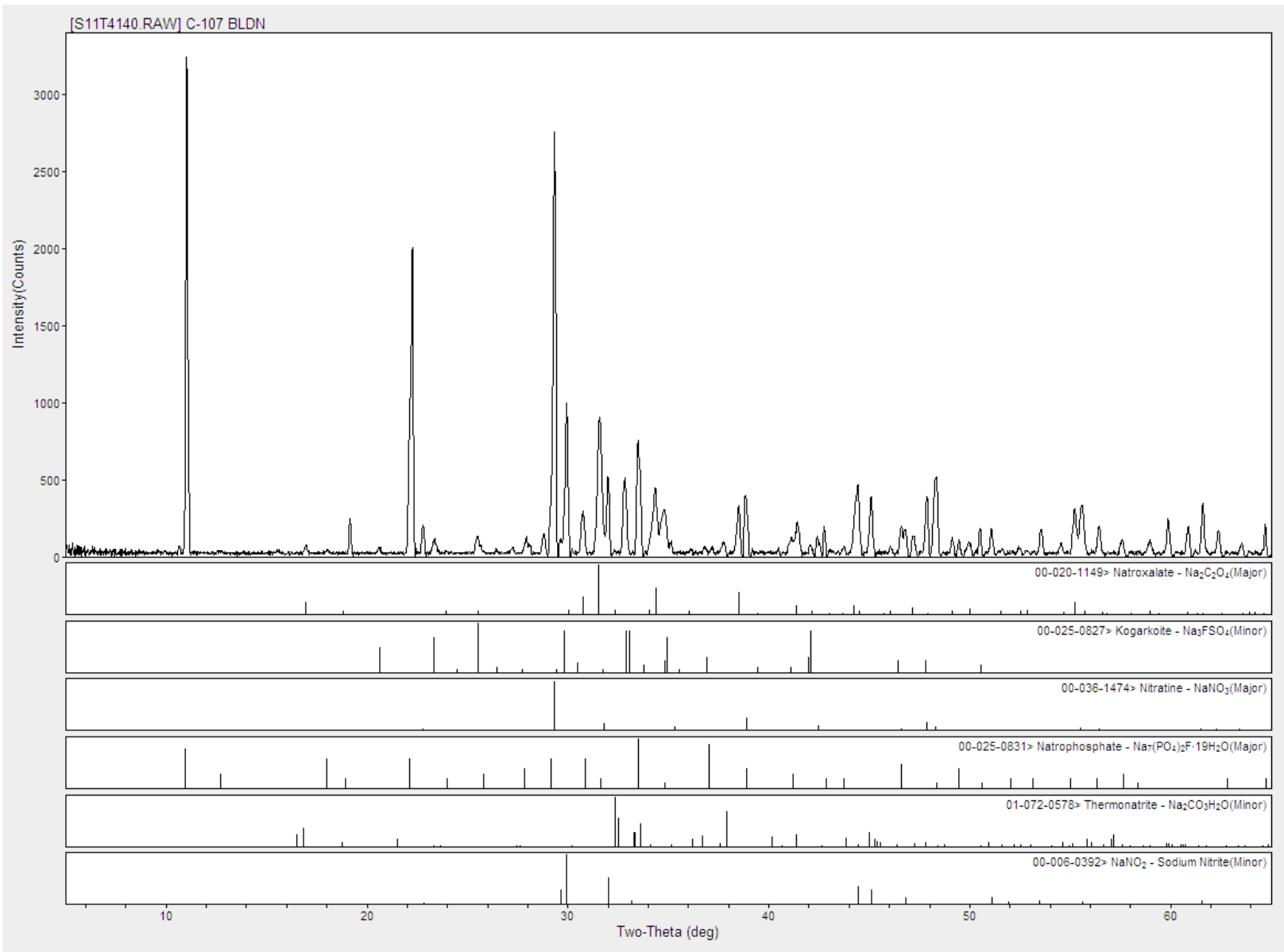




\section{PLM Results (S11T014140)}

Natrophosphate crystals and small $(<20 \mu \mathrm{m})$ natroxalate needles and clusters were observed.

Figure PLM-1. Sample S11T014140.

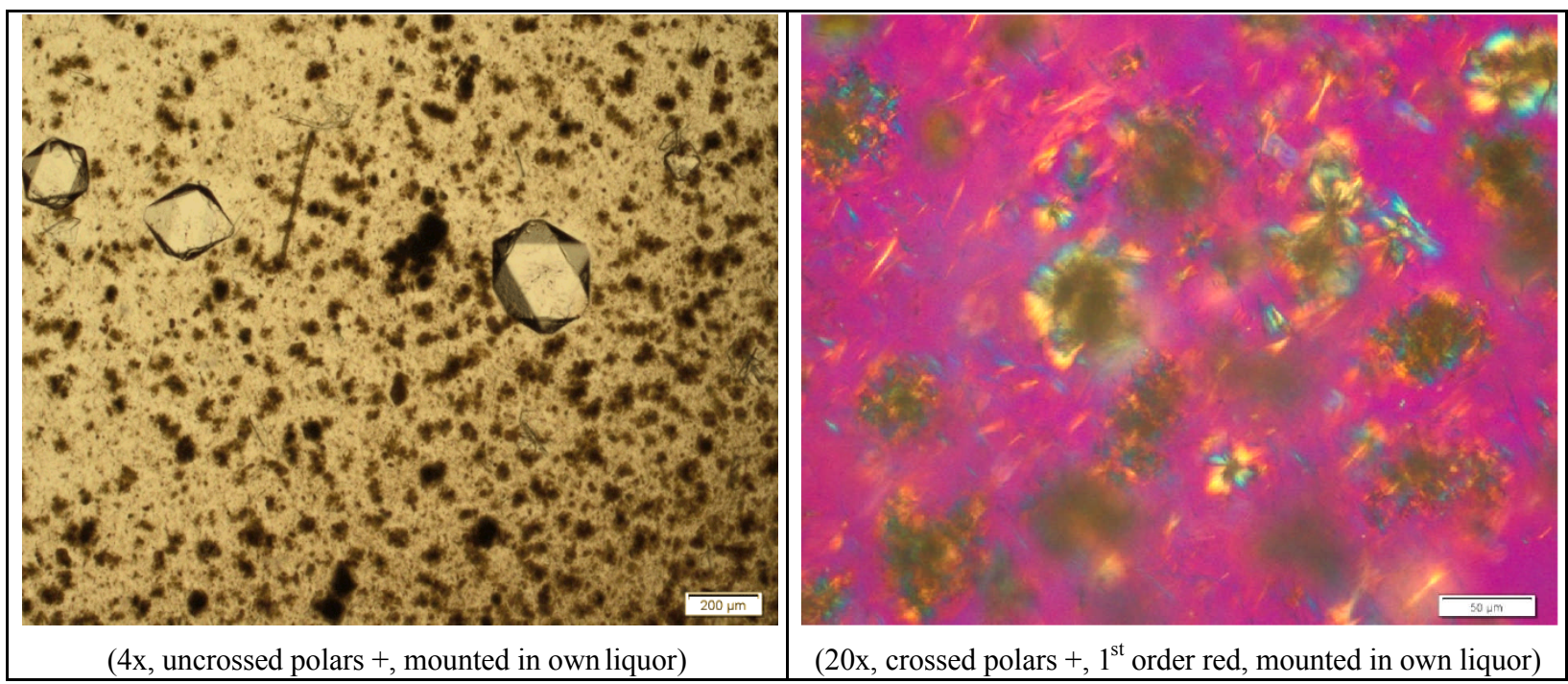




\section{SEM/EDX Results (S11T014140)}

The solid particulates were a mix of acicular (needle-like), hexagonal plate, and octahedral particles. One example of the hexagonal plate particles is shown in Figure SEM-1 including an EDX spectrum acquired from the location marked with a yellow '+'. The left SEM image shows the general area containing the hexagonal particles, and the right image is a magnified view of a twinned particle. The particle was composed of sodium, fluorine, sulfur, and oxygen. These sodium fluoride sulfate particles were identified as kogarkoite based upon the elemental composition and morphology.

Figure SEM-1. SEM Images and EDX Spectrum of Kogarkoite Particle from S11T014140.

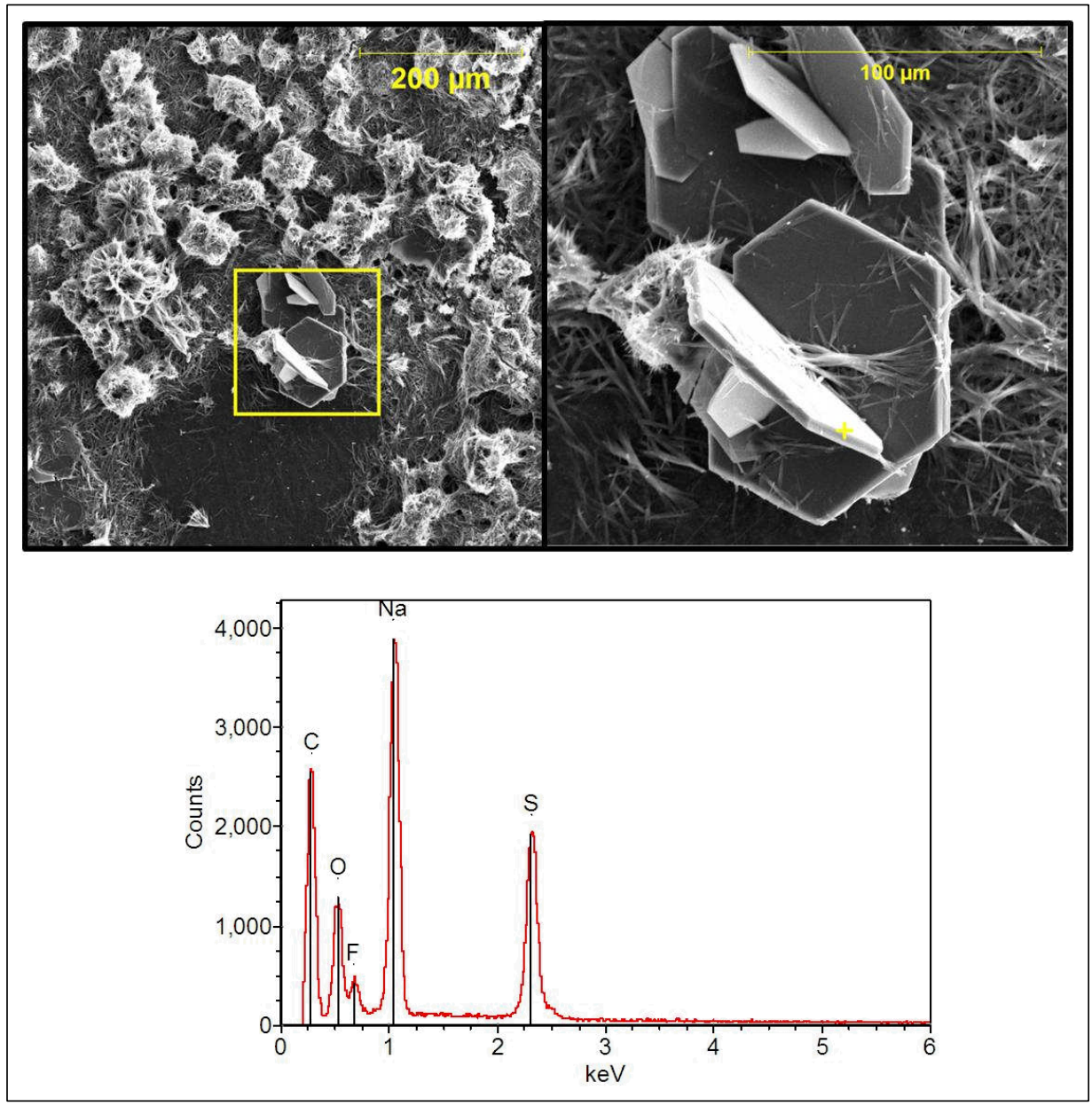

Further examination of the acicular particulate is shown in Figure SEM-2. Here, several spots free from underlying particles were selected for EDX analysis (underlying particles can also give off X-rays complicating EDX spectra interpretation). The spectra suggest that there are at least two different phases making up the acicular particulate; one containing sodium and oxygen (possibly sodium oxalate) and another containing sodium, oxygen, and sulfur. 
Figure SEM-2. SEM Image and EDX Spectra of Various Acicular Particles in S11T011040.

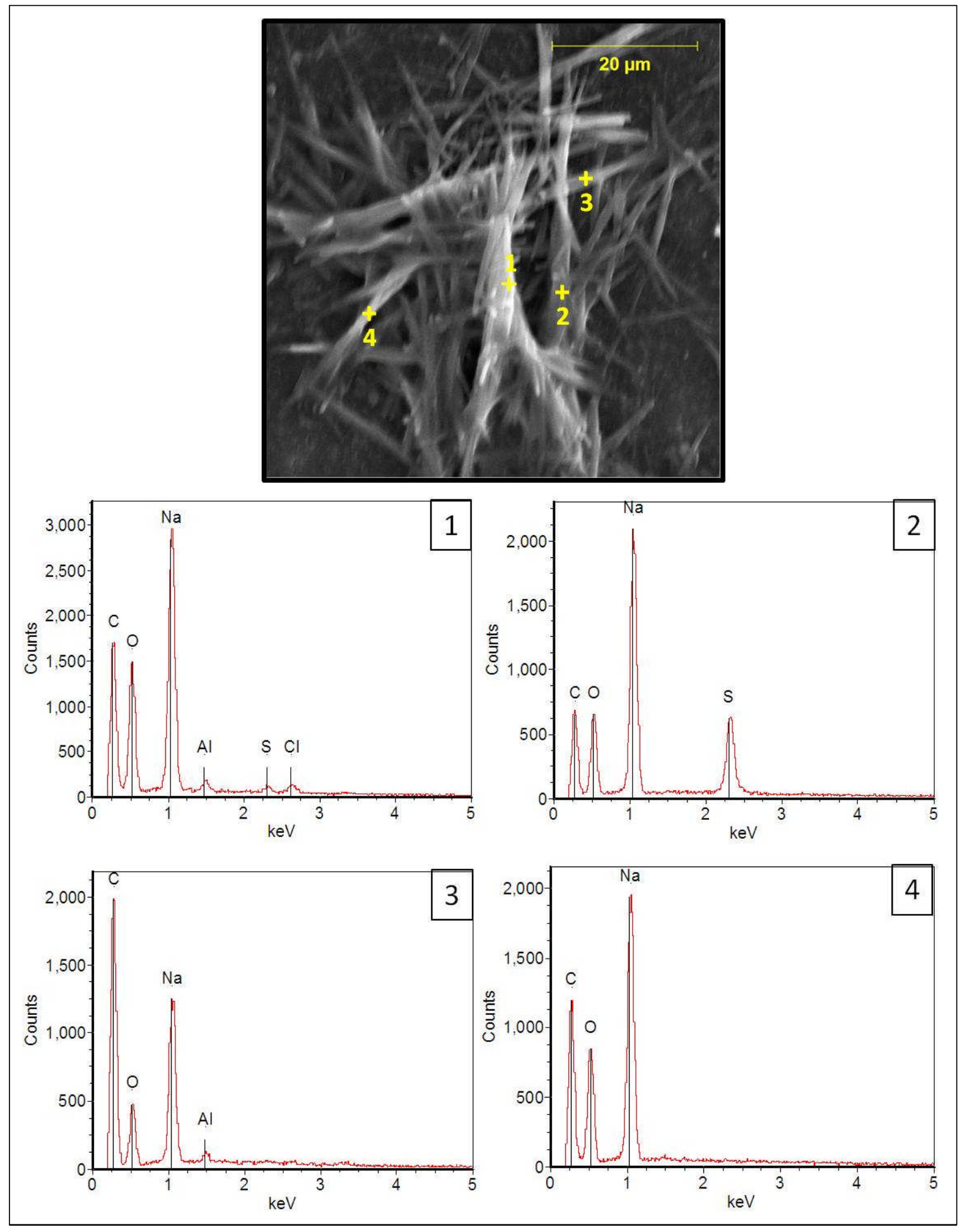


Figure SEM-3 shows that the acicular particles are typically $\approx 20 \mu \mathrm{m}$ in length and $\approx 1.5 \mu \mathrm{m}$ wide.

Figure SEM-3. SEM Image Showing Typical Dimensions of Acicular Particles in S11T014140.

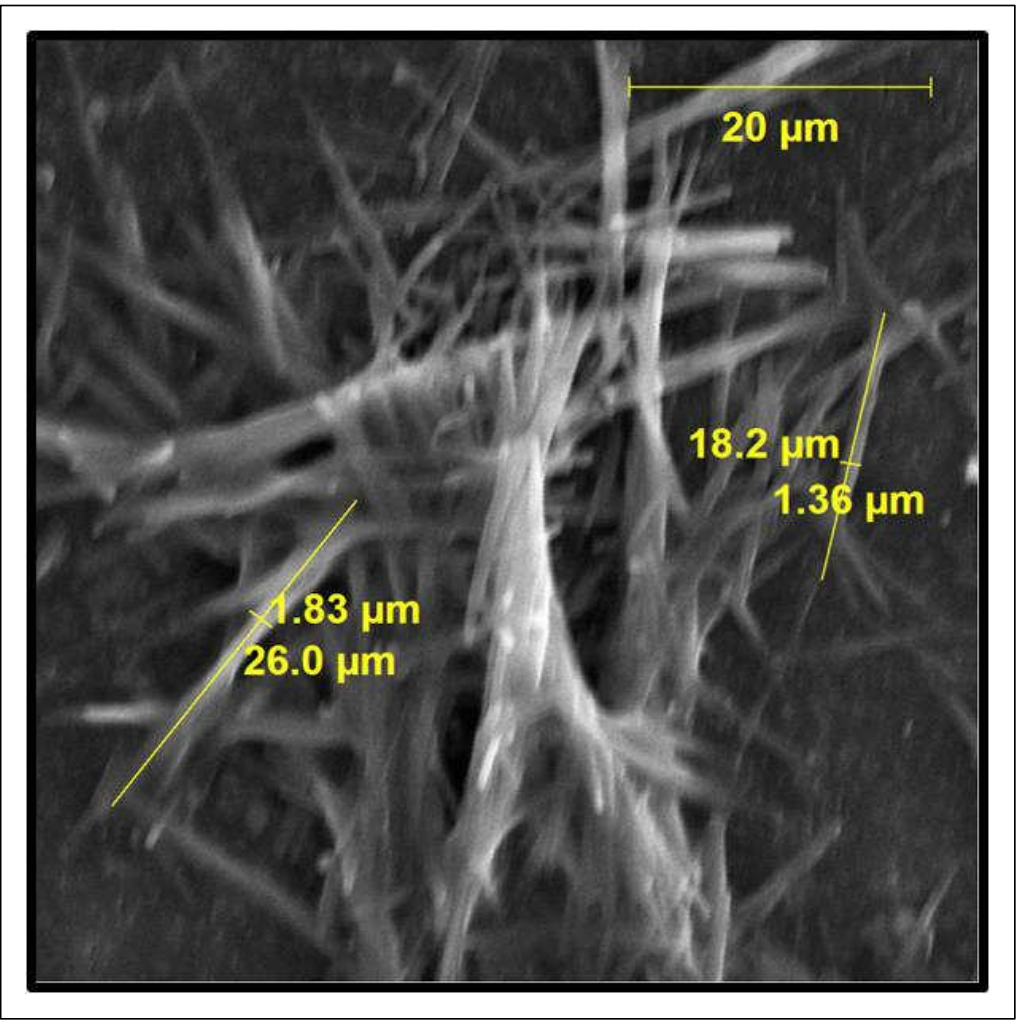

Another location of well-dispersed acicular solids is shown in Figure SEM-4. Analyses of the particles (EDX analysis spots indicated by yellow ' + ' signs in the left image) show a single phase composing sodium and oxygen. A feature with these particles is highlighted in the right image. A circle was drawn around each spot where an EDX spectrum was acquired. Beam damage at these points is visible as dark spots. Previous studies of tank waste showed that this phenomenon is common with sodium carbonate, and this assignment fits well with the EDX spectra for these solids. 
Figure SEM-4. SEM Images and EDX Spectra of Sodium Carbonate Particles in S11T014140.
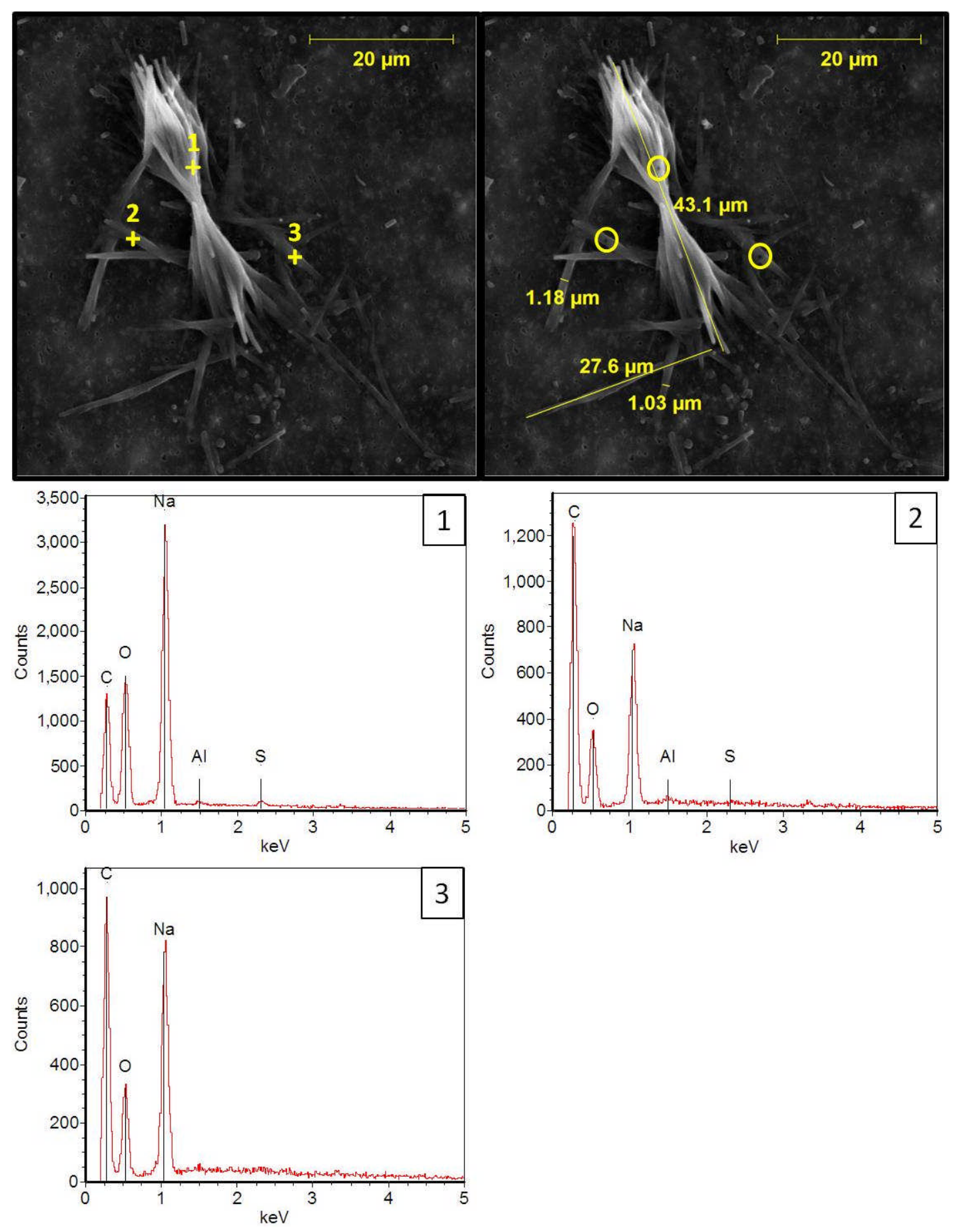
Another common feature observed in Sample S11T014140 was the aggregation of the acicular particles. Often, this created clumps as seen in most of the region in the left image of

Figure SEM-5. However, occasionally, these clumps took the form of spheres (right image). The EDX spectra from the clumps and the spheres are very similar suggesting that they are composed of the same solid phase.

Figure SEM-5. SEM Images and EDX Spectra of Clumps of Acicular Particles in S11T014140.

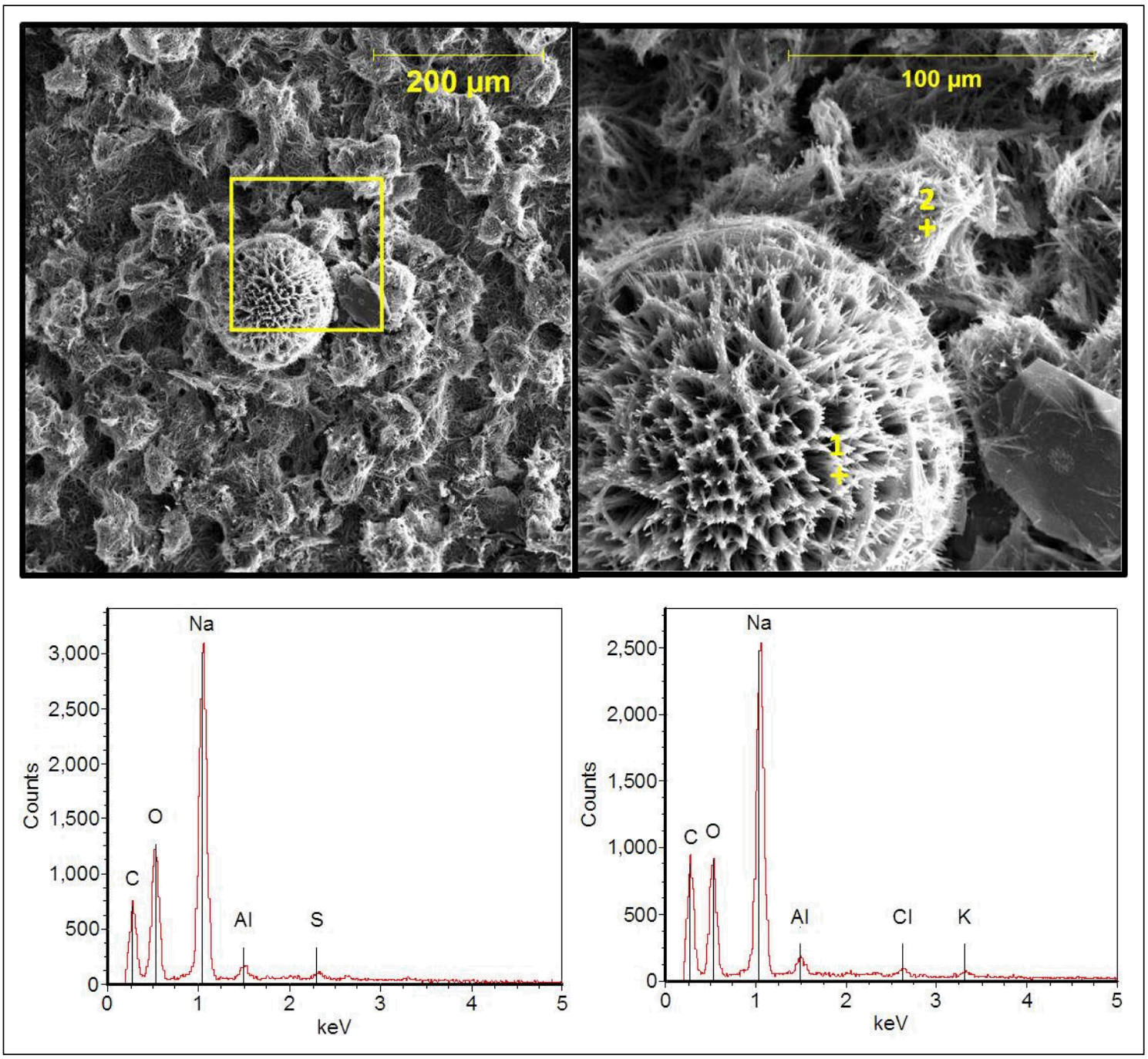


Octahedral particles were observed throughout Sample S11T014140. Figure SEM-6 shows several of these particles (left image) and a magnification of a particle (right image). These particles are identified as sodium fluoride phosphate (natrophosphate) based on the distinctive morphology and the EDX spectrum.

Figure SEM-6. SEM Images and EDX Spectrum of a Natrophosphate Particle in S11T014140.
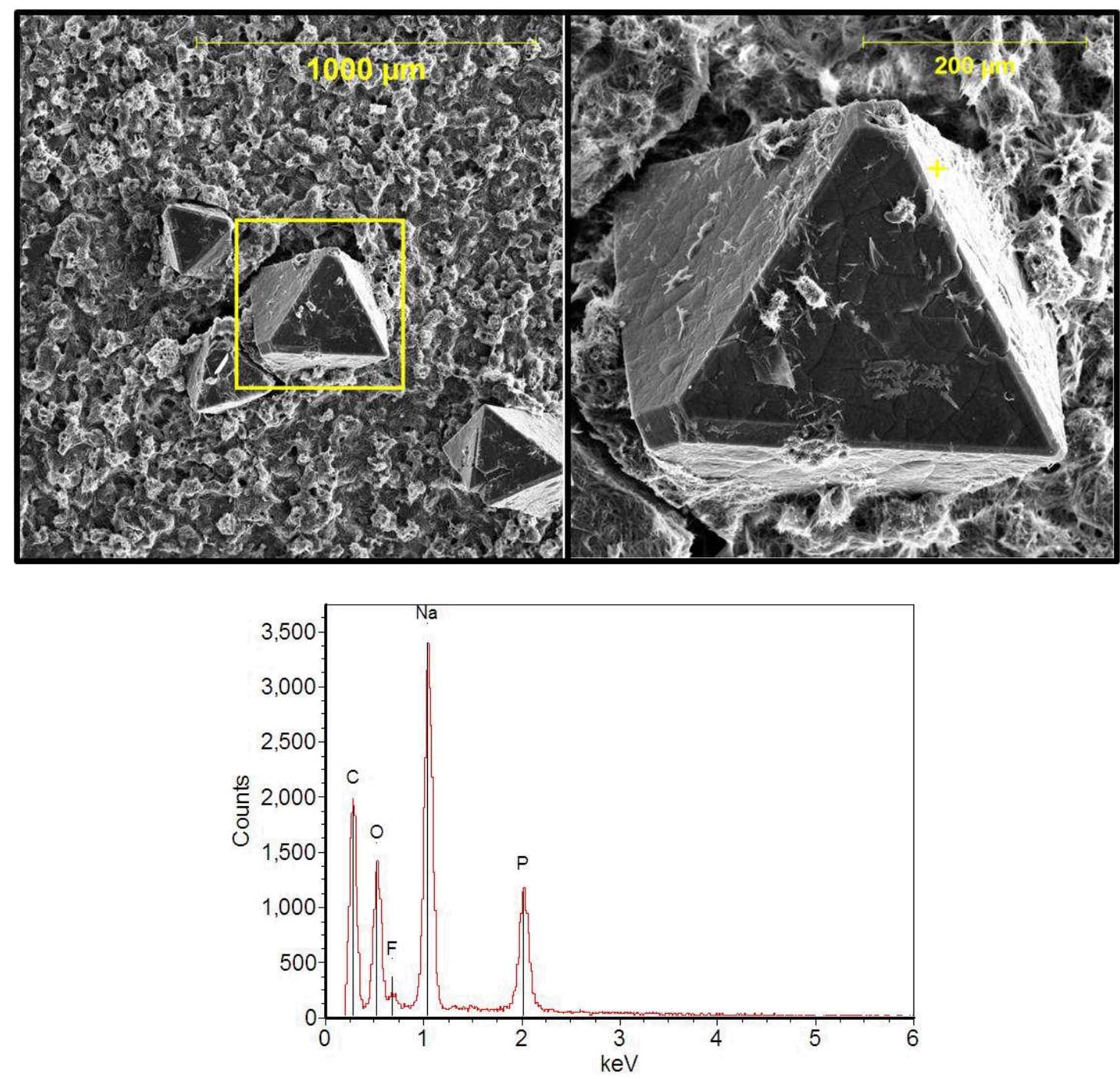


\section{Sample S11T014141: Composite of Solids from Boildown Samples CON $4\left(46.1 \% \mathrm{WVR}^{18}{ }^{\circ} \mathrm{C}\right)$ and $\operatorname{CON} 5\left(50.2 \% \mathrm{WVR}^{18}{ }^{\circ} \mathrm{C}\right)$}

\section{XRD Results}

Nitratine $\left(\mathrm{NaNO}_{3}\right)$ was identified as a major phase and sodium nitrite $\left(\mathrm{NaNO}_{2}\right)$ as a minor phase of the sample; they are speculated to have crystallized from the interstitial liquid when the sample was dried. Thermonatrite $\left(\mathrm{Na}_{2} \mathrm{CO}_{3} \cdot \mathrm{H}_{2} \mathrm{O}\right)$ was identified as a minor phase of the sample. Natroxalate $\left(\mathrm{Na}_{2} \mathrm{C}_{2} \mathrm{O}_{4}\right)$ and natrophosphate $\left[\mathrm{Na}_{7} \mathrm{~F}\left(\mathrm{PO}_{4}\right)_{2} \bullet 19 \mathrm{H}_{2} \mathrm{O}\right]$ were identified as trace phases of the sample.

\begin{tabular}{llll} 
Chemical Name & Mineral Name & Formula & Relative Amount \\
\hline Sodium Nitrate & Nitratine & $\mathrm{NaNO}_{3}$ & Major \\
Sodium Nitrite & --- & $\mathrm{NaNO}_{2}$ & Minor \\
Sodium Carbonate Hydrate & Thermonatrite & $\mathrm{Na}_{2} \mathrm{CO}_{3} \cdot \mathrm{H}_{2} \mathrm{O}$ & Minor \\
Sodium Oxalate & Natroxalate & $\mathrm{Na}_{2} \mathrm{C}_{2} \mathrm{O}_{4}$ & Trace \\
Sodium Fluoride Phosphate Hydrate & Natrophosphate & $\mathrm{Na}_{7} \mathrm{~F}\left(\mathrm{PO}_{4}\right)_{2} \cdot 19 \mathrm{H}_{2} \mathrm{O}$ & Trace
\end{tabular}

Figure XRD-2. Sample S11T014141.

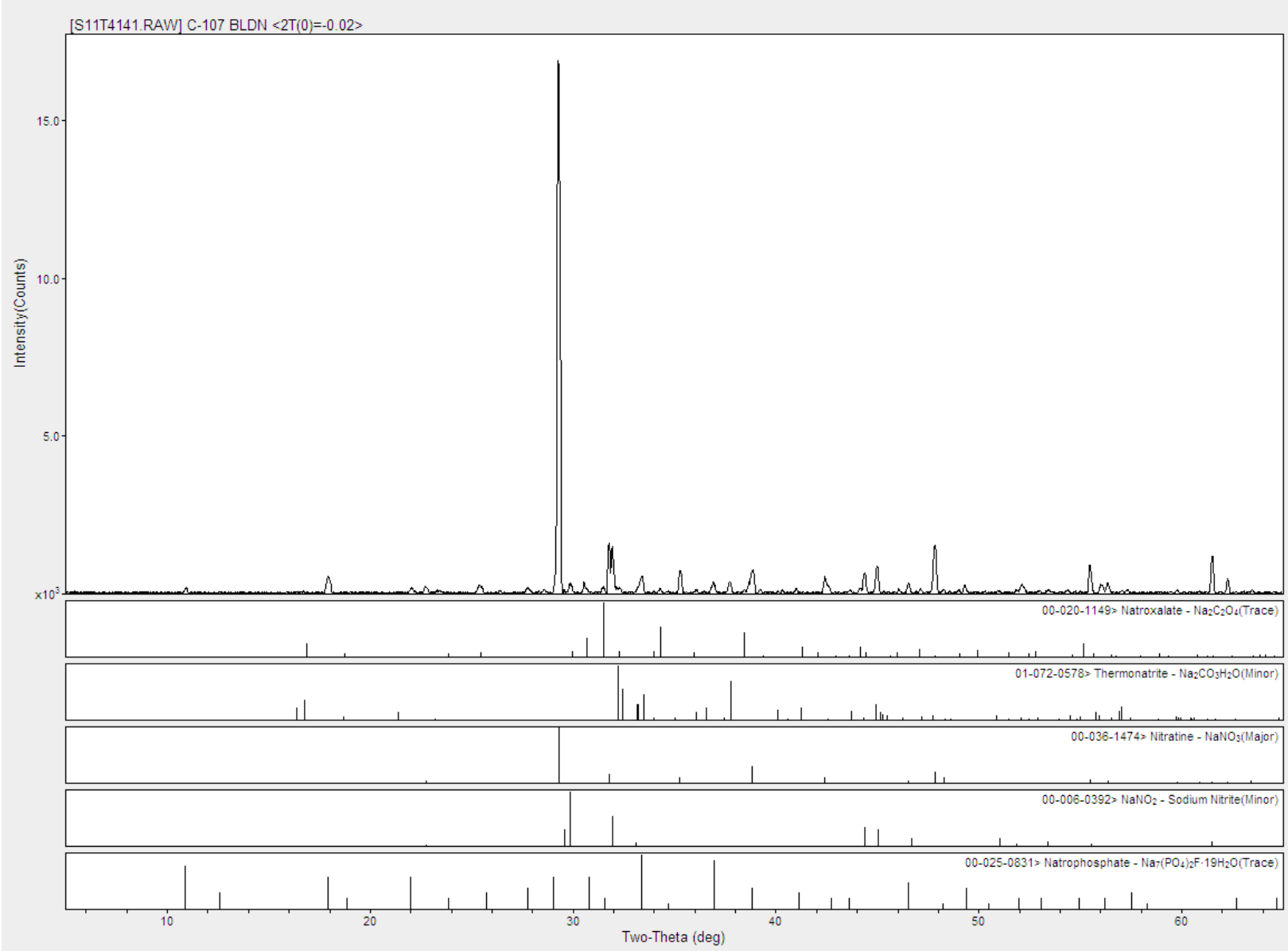




\section{PLM Results (S11T014141)}

Natrophosphate crystals and natroxalate needles were observed.

Figure PLM-2. Sample S11T014141.

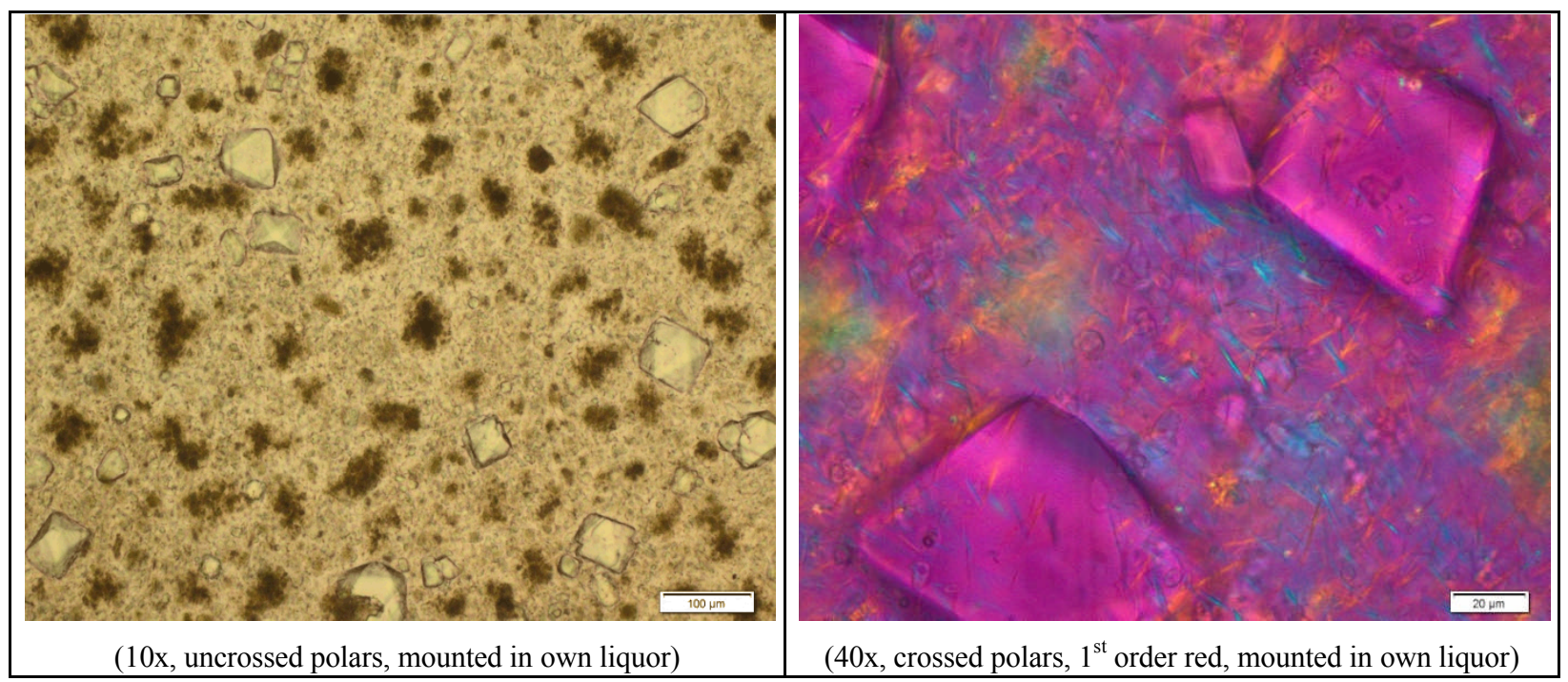




\section{SEM/EDX Results (S11T014141)}

The solids were a mix of acicular particles $(\approx 6-8 \mu \mathrm{m} \times 0.8 \mu \mathrm{m})$, euhedral, hexagonal particles (up to $30 \mu \mathrm{m}$ in size), and octahedral particles (many over $50 \mu \mathrm{m}$ in size). Figure SEM-7 shows a typical area of the specimen (left image). The expanded image on the right provides more detail on the acicular and euhedral particulates. Analysis of the acicular particles (EDX Spots 1 and 2) indicate the elemental composition is dominated by sodium and oxygen with traces of sulfur, potassium, and aluminum. The EDX spectra from the euhedral particles (Spots 3 and 4) indicate that these solids are sodium fluoride sulfate (kogarkoite).

Figure SEM-7. SEM Images and EDX Spectra of Solids in S11T014141.

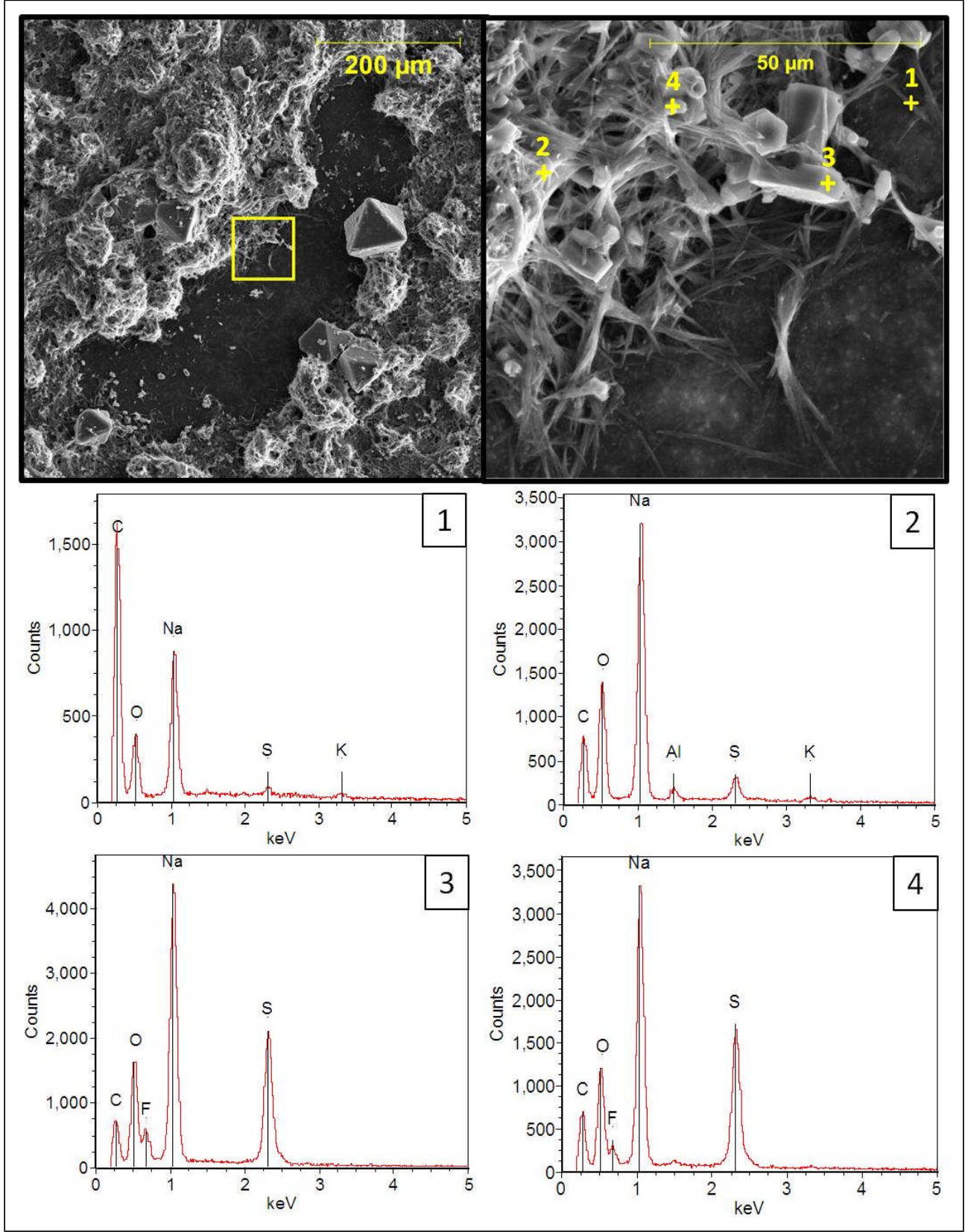


Further analysis of the acicular particles, Figure SEM-8, confirmed that these solids were composed mainly of sodium and oxygen with trace sulfur. The chlorine and potassium in the EDX spectrum from Spot 1 could be surface residue. Based upon these results, these acicular particles were identified as sodium oxalate (natroxalate). Beam damage (dark marks) of the crystals during EDX spectrum acquisition (most prominent at Spot 1) could indicate that the particles are very thin.

Figure SEM-8. SEM Image and EDX Spectra from Acicular Solids in S11T014141.

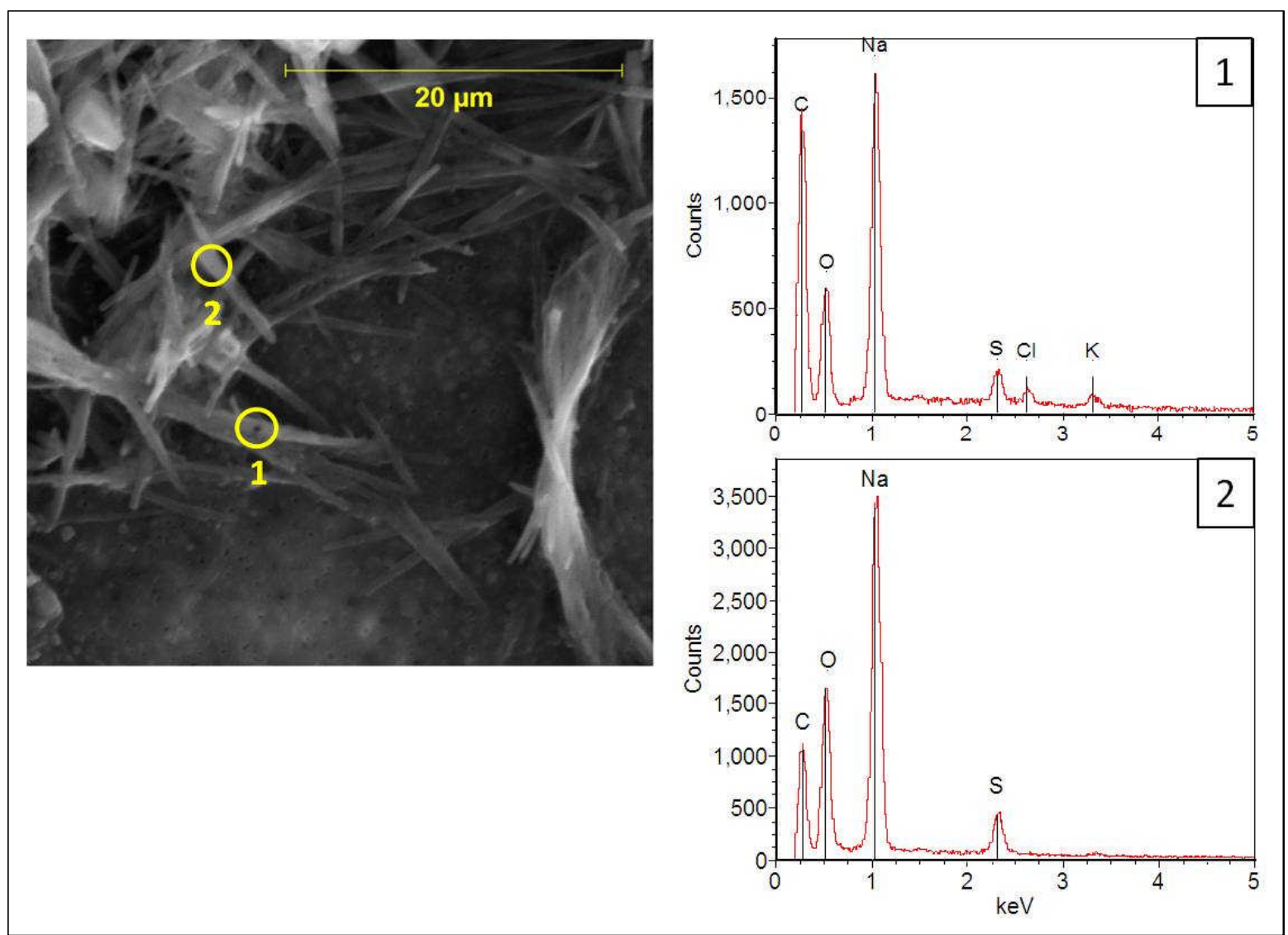


Another image of the small euhedral particles, many displaying a hexagonal to hexagonal-rod morphology, is shown in Figure SEM-9. Elemental analysis (EDX Spot 1) confirmed the identification of these solids as sodium fluoride sulfate. The beam damage visible at Spot 1 again suggests that these particles may be very thin. The spectrum from Spot 2 is characteristic of sodium oxalate. The spectrum from Spot 3 shows a calcium-rich particle (this was the only calcium-rich particle observed in this sample).

Figure SEM-9. SEM Image and EDX Spectra of Small Euhedral Particules in S11T014141.
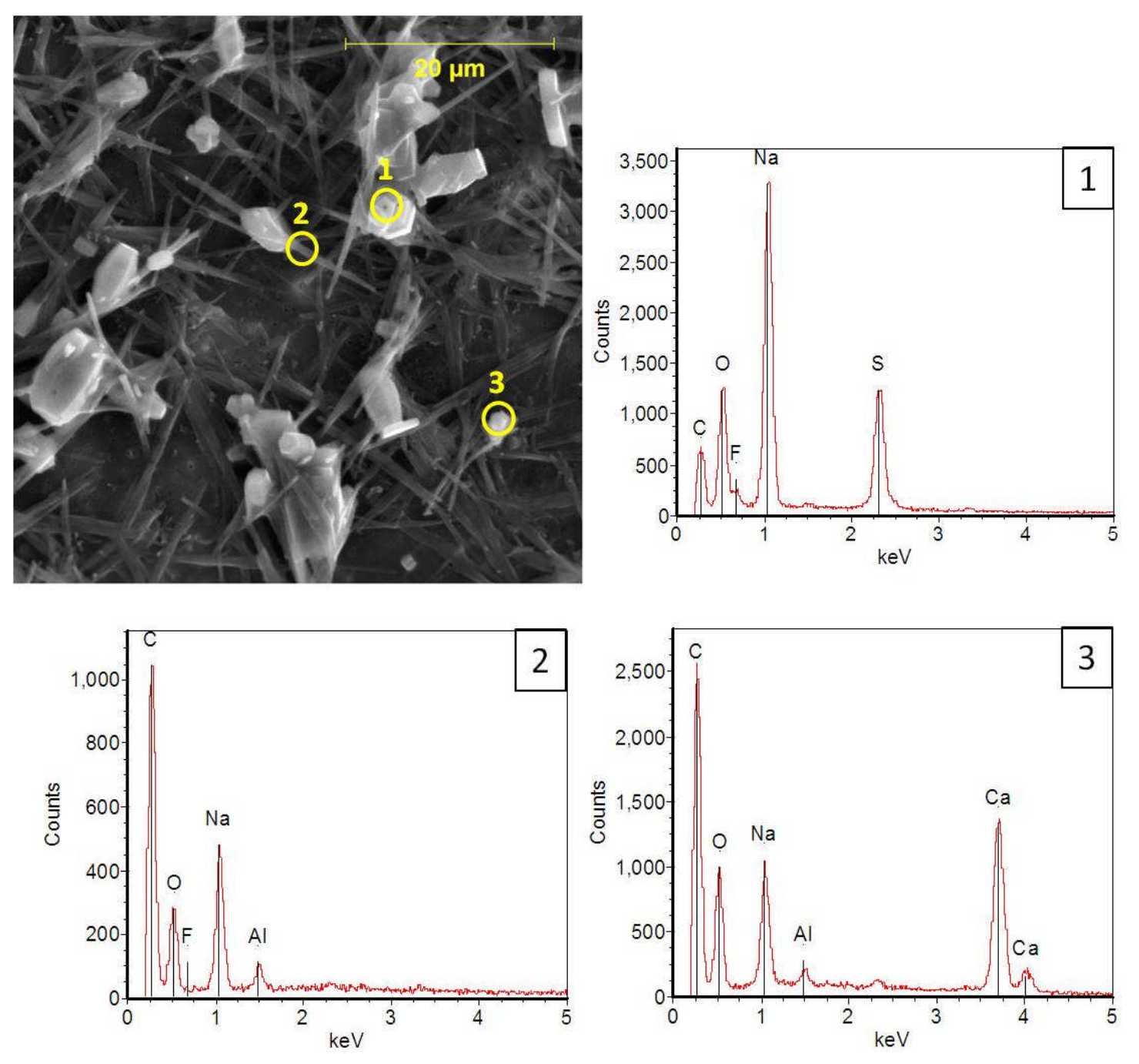
Larger octahedral particles were scattered throughout the SEM specimen, Figure SEM-10. Again, the distinct morphology and EDX spectrum indicates these solids are natrophosphate.

Figure SEM-10. SEM Image and EDX Spectrum of a Natrophosphate Particle in S11T014141.
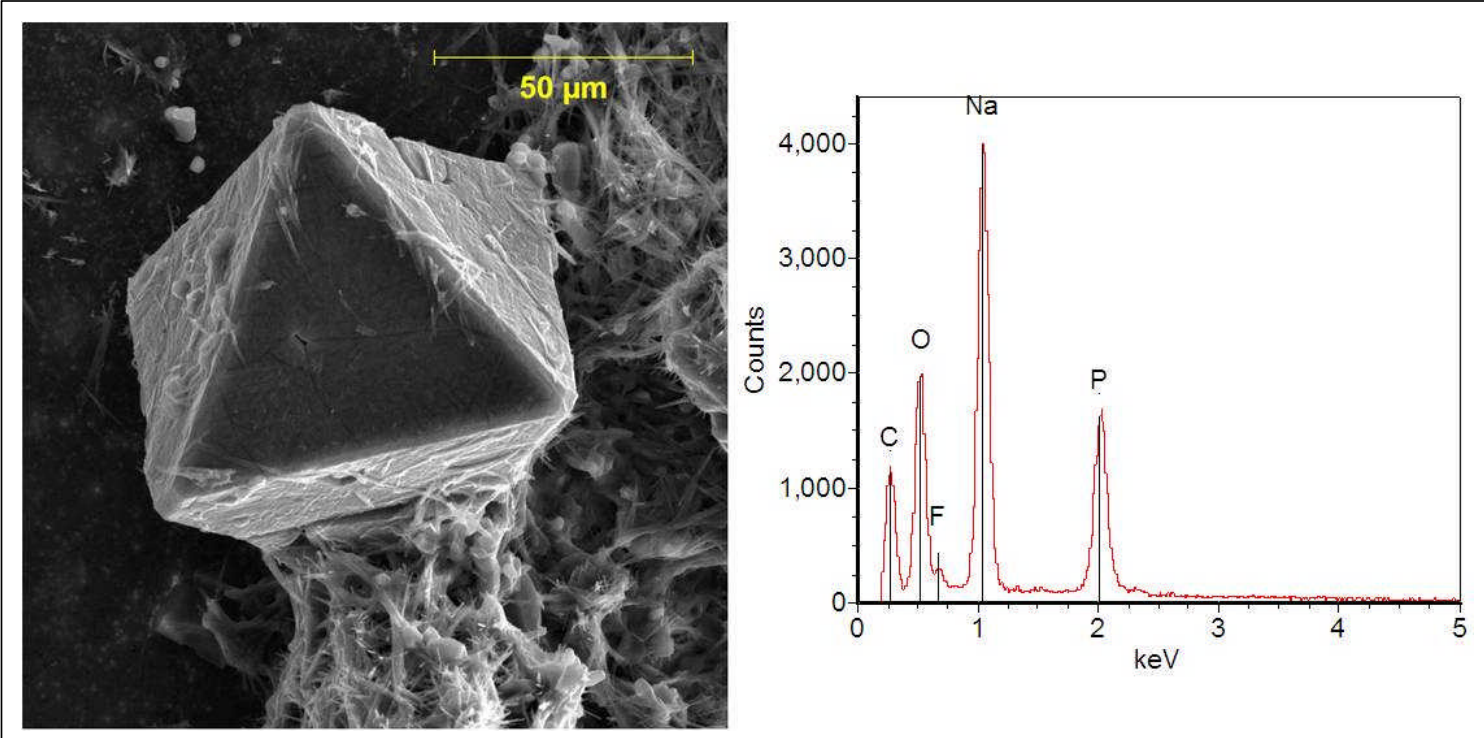

Sodium chloride was observed in trace amounts in the matted particulate on the SEM specimen, Figure SEM-11.

Figure SEM-11. SEM Image and EDX Spectrum of Sodium Chloride Particles in S11T014141.

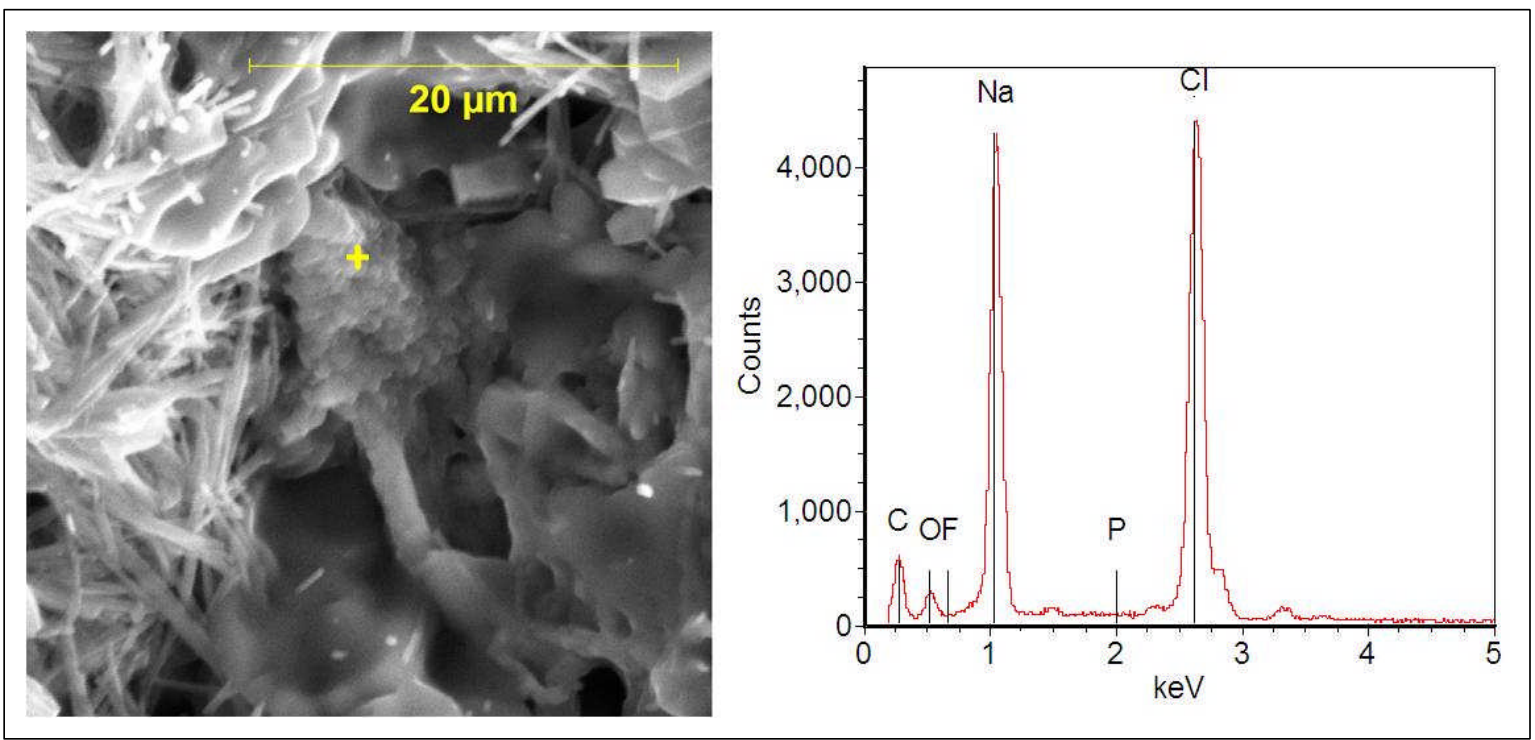


Small plate-like particles were also observed (at a lower abundance) in the matted particulate on the SEM specimen, Figure SEM-12. The EDX spectrum indicates the presence of sodium and oxygen with a trace of potassium. Based on the morphology and elemental composition, these solids were identified as sodium carbonate. A prominent beam damage spot is visible in the right image.

Figure SEM-12. SEM Images and EDX Spectrum of a Sodium Carbonate Particle in S11T014141.

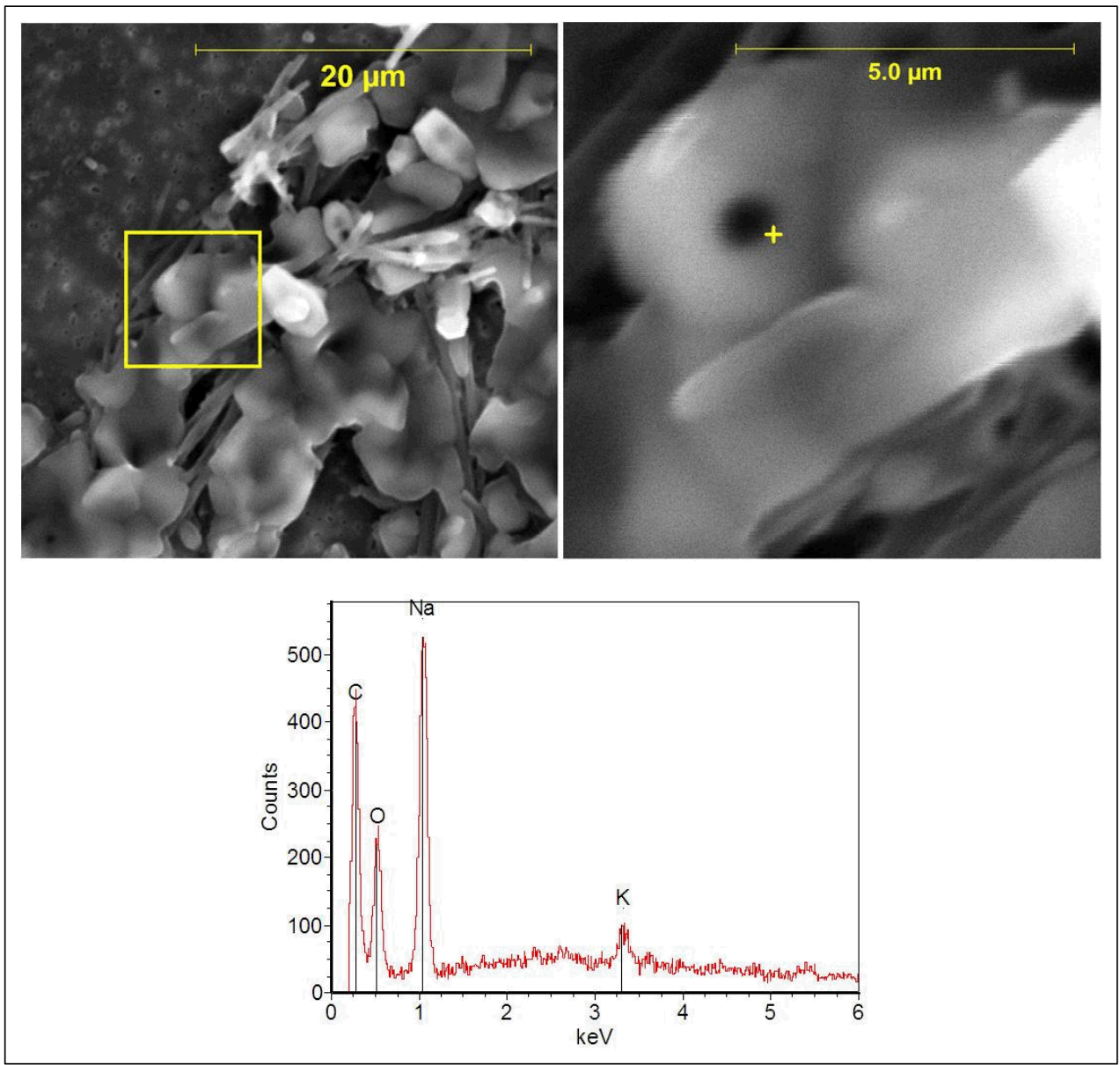




\section{Sample S11T014280: Solids from Boildown Sample CON $6\left(54.0 \% \mathrm{WVR}^{18}{ }^{\circ} \mathrm{C}\right)$}

\section{XRD Results}

Nitratine $\left(\mathrm{NaNO}_{3}\right)$ was identified as a major phase and sodium nitrite $\left(\mathrm{NaNO}_{2}\right)$ as a trace phase in the sample; both are speculated to have crystallized from the interstitial liquid when the sample was dried. Natrophosphate $\left[\mathrm{Na}_{7} \mathrm{~F}\left(\mathrm{PO}_{4}\right)_{2} \bullet 19 \mathrm{H}_{2} \mathrm{O}\right]$ and thermonatrite $\left(\mathrm{Na}_{2} \mathrm{CO}_{3} \bullet \mathrm{H}_{2} \mathrm{O}\right)$ were identified as minor phases in the sample.

\section{Chemical Name}

Sodium Nitrate

Sodium Nitrite

Sodium Fluoride Phosphate Hydrate

Sodium Carbonate Hydrate
Mineral Name

Nitratine

$--$

Natrophosphate

Thermonatrite
Formula

$\mathrm{NaNO}_{3}$

$\mathrm{NaNO}_{2}$

$\mathrm{Na}_{7} \mathrm{~F}\left(\mathrm{PO}_{4}\right)_{2} \bullet 19 \mathrm{H}_{2} \mathrm{O}$

$\mathrm{Na}_{2} \mathrm{CO}_{3} \cdot \mathrm{H}_{2} \mathrm{O}$
Relative Amount

Major

Trace

Minor

Minor

Figure XRD-3. Sample S11T014280.

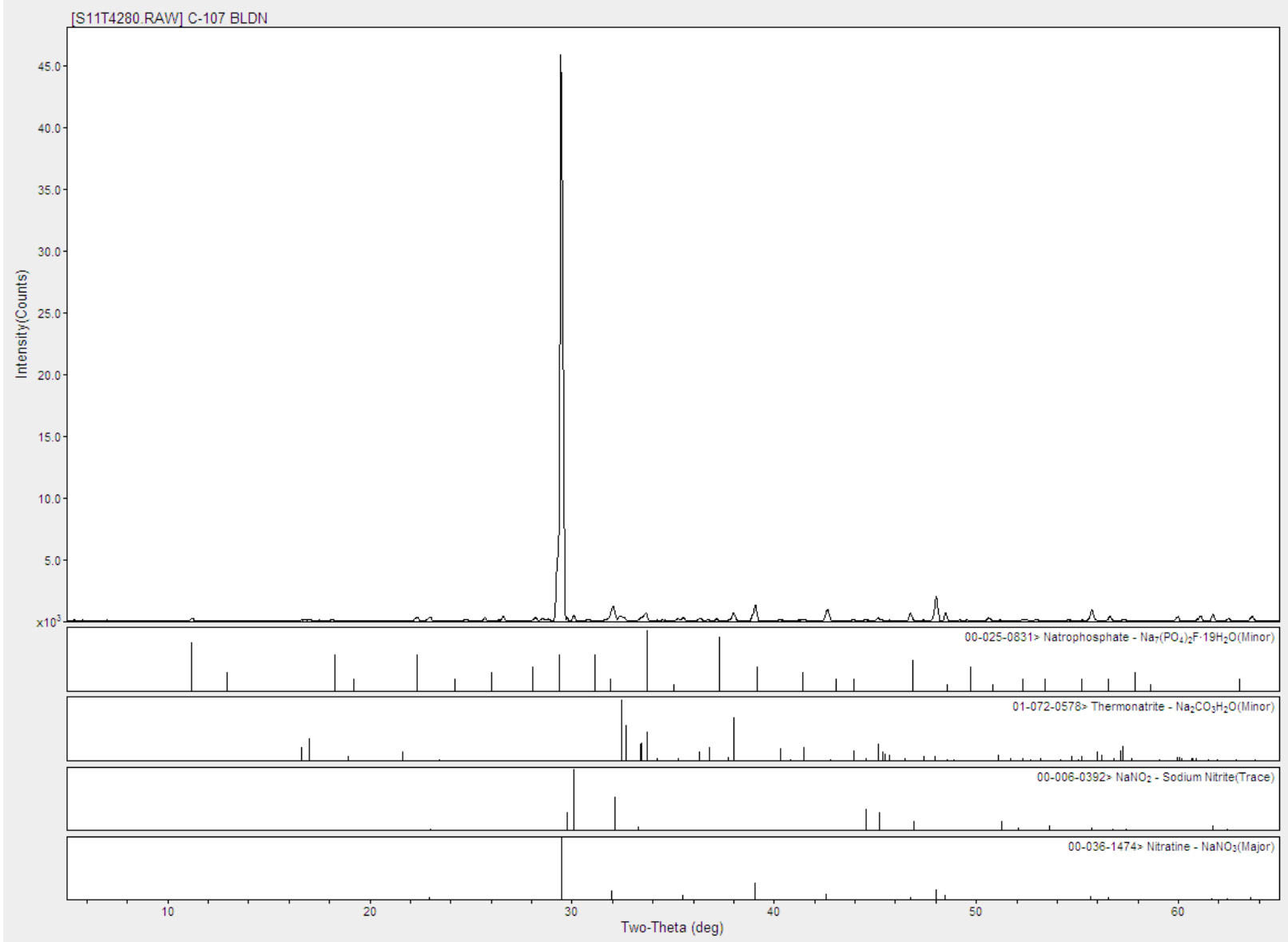




\section{PLM Results (S11T014280)}

Sodium nitrate crystals, natrophosphate crystals, sodium phosphate needles (see close-up), and natroxalate needles were identified. Sodium phosphate and natroxalate needles have the same shape but opposite orientation.

Figure PLM-3. Sample S11T014280.

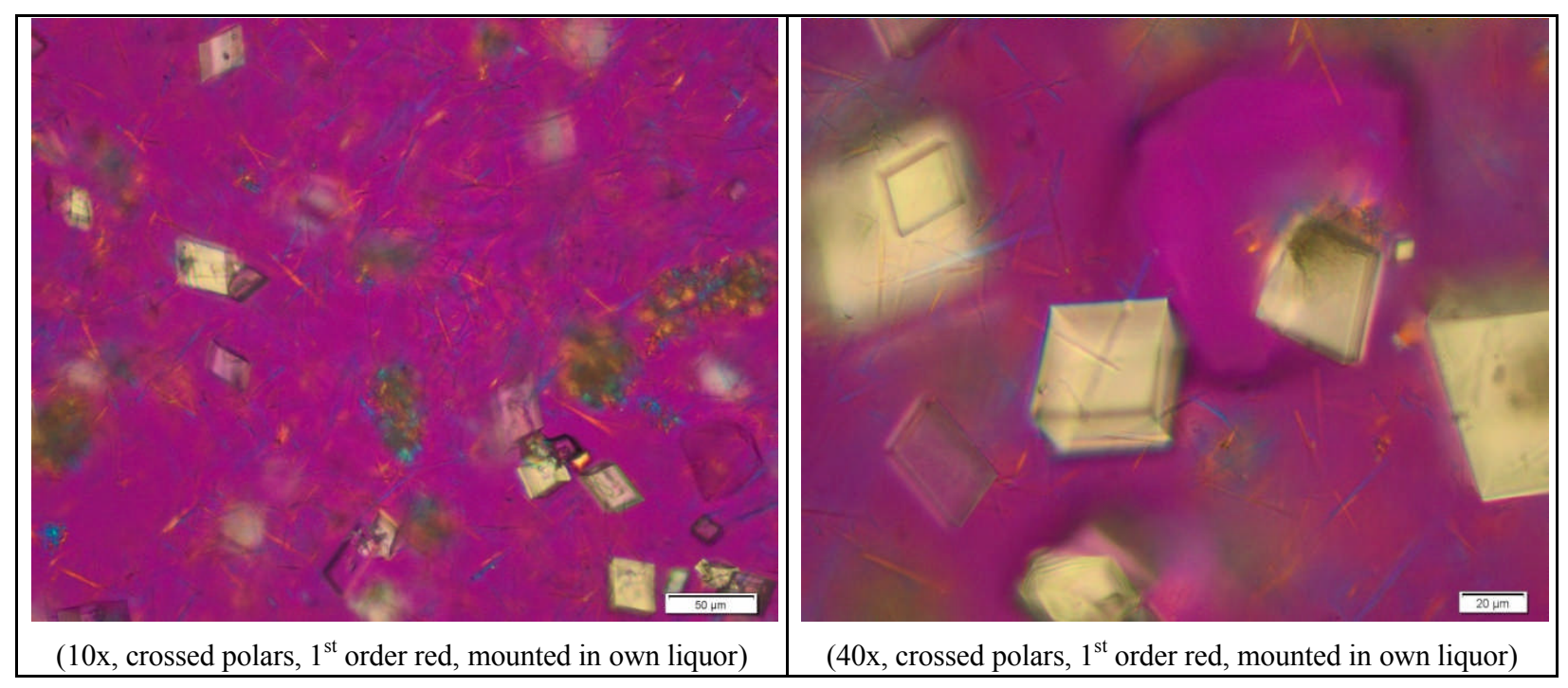




\section{SEM/EDX Results (S11T014280)}

The solids in the sample were dominated by acicular particles. A mix of small subhedral and large euhedral particles were also observed. The left image in Figure SEM-13 is representative of the specimen. The right image is an expanded view of one of the large euhedral particles identified as natrophosphate.

\section{Figure SEM-13. SEM Images and EDX Spectrum of a Natrophosphate Particle in S11T014280.}

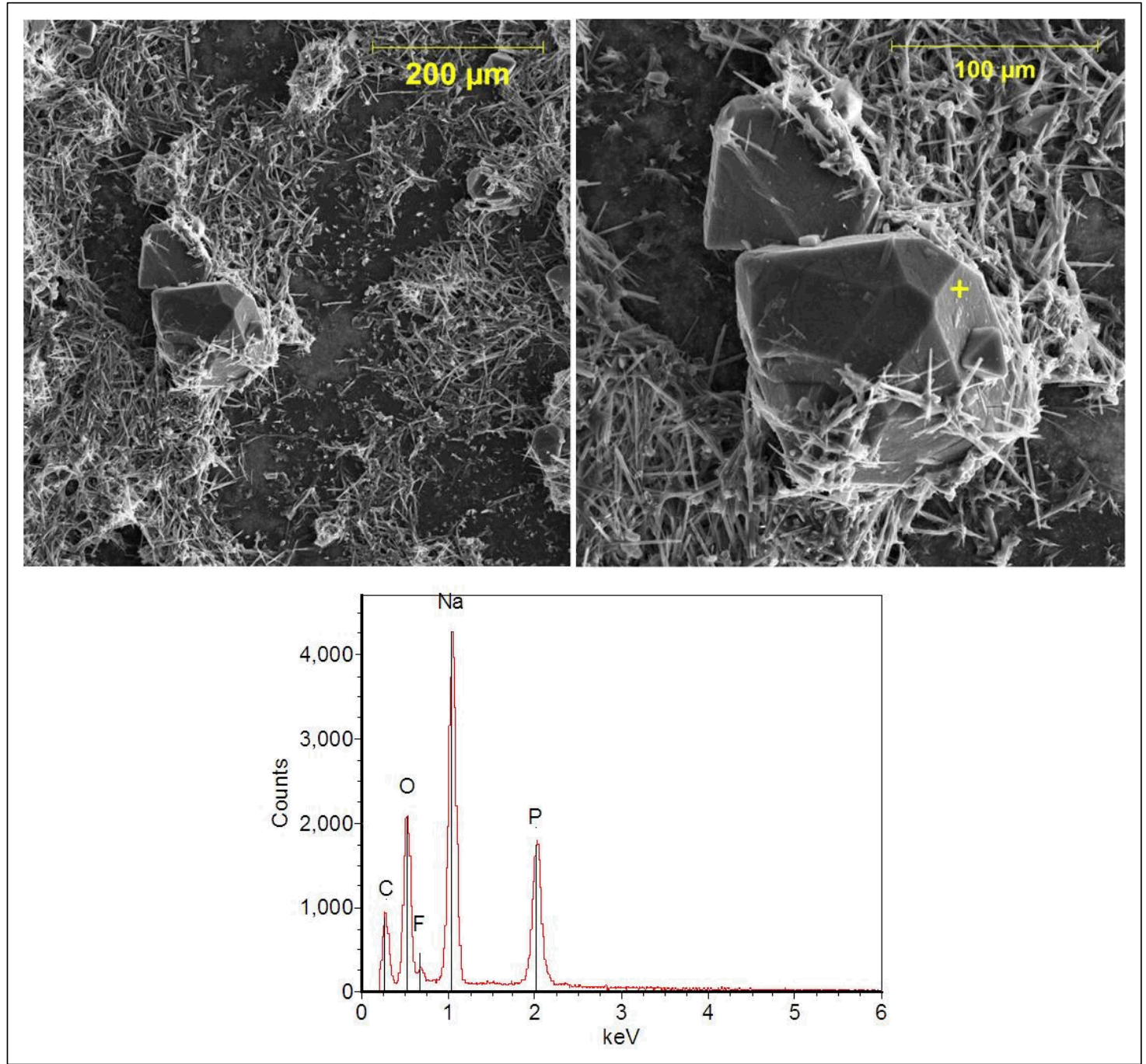

The particulates making up the nearly continuous mat of solids on the specimen were examined further in Figure SEM-14. Several acicular particles (EDX Spots 1-3) were found to contain sodium, oxygen, fluorine, and sulfur with varying amounts of aluminum. This appears to be another phase of sodium fluoride sulfate. One of the smaller subhedral particles was also analyzed (EDX Spot 5), and showed an elemental composition similar to that of the acicular particles with minor amounts of chlorine and potassium. An amorphous, cementing phase, 
EDX Spot 4, was observed at several locations on the particulate mat. Elemental analysis showed it to be sodium nitrate, possibly precipitated from the sample supernatant liquid during the sample preparation.

Figure SEM-14. SEM Image and EDX Spectra of Dominant Solids in S11T014280.
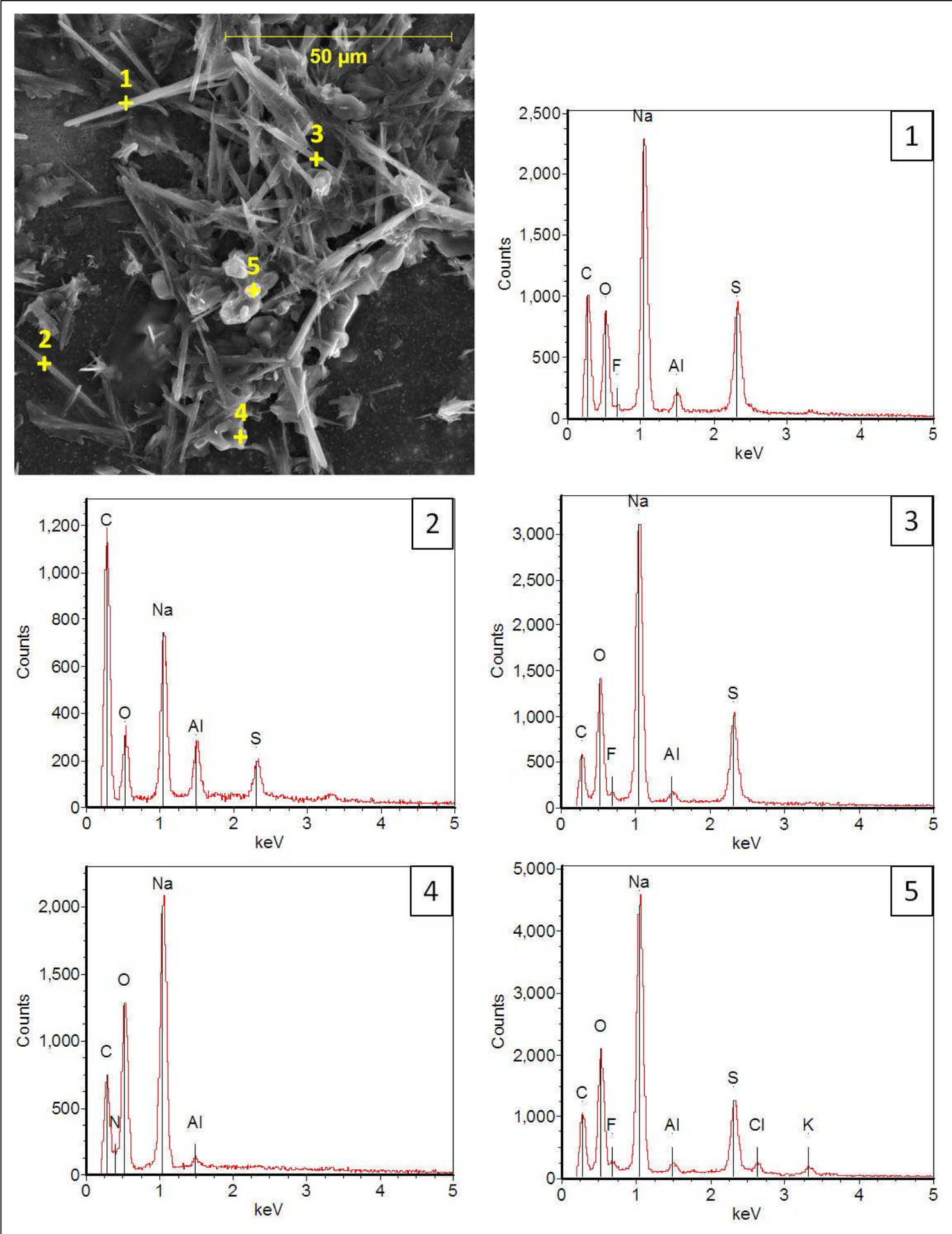
Two different sodium fluoride sulfate phases posited to be present in the sample are shown in Figure SEM-15. One acicular particle and one subhedral particle were chosen for EDX analysis. The resulting spectra show them to be very similar in elemental composition.

Figure SEM-15. SEM Image and EDX Spectra of Sodium Fluoride Sulfate Phases in S11T014280.

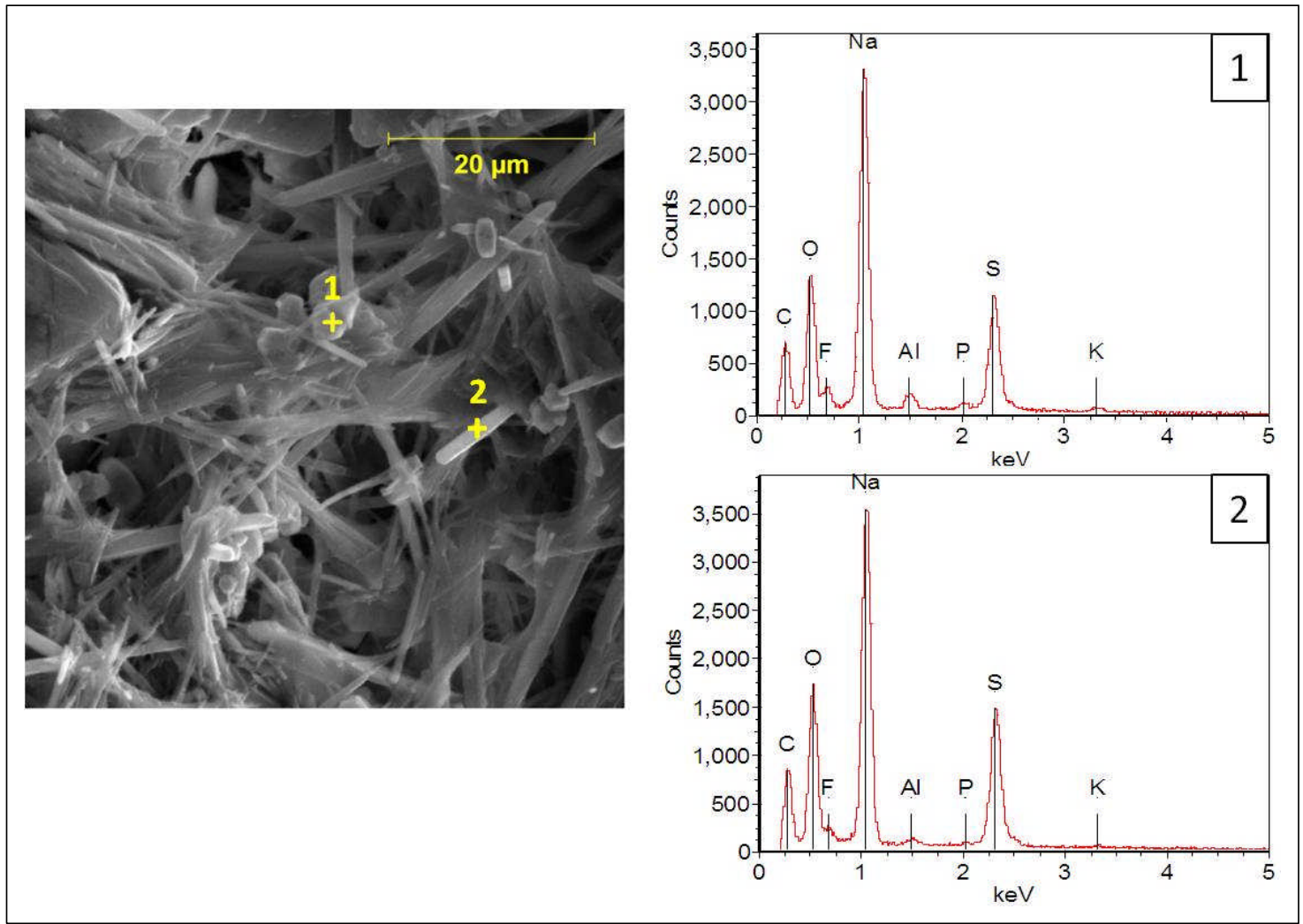

Trace quantities of a subhedral, calcium-rich phase was also observed, Figure SEM-16.

Figure SEM-16. SEM Image and EDX Spectrum of Calcium-Rich Phase in S11T014280.
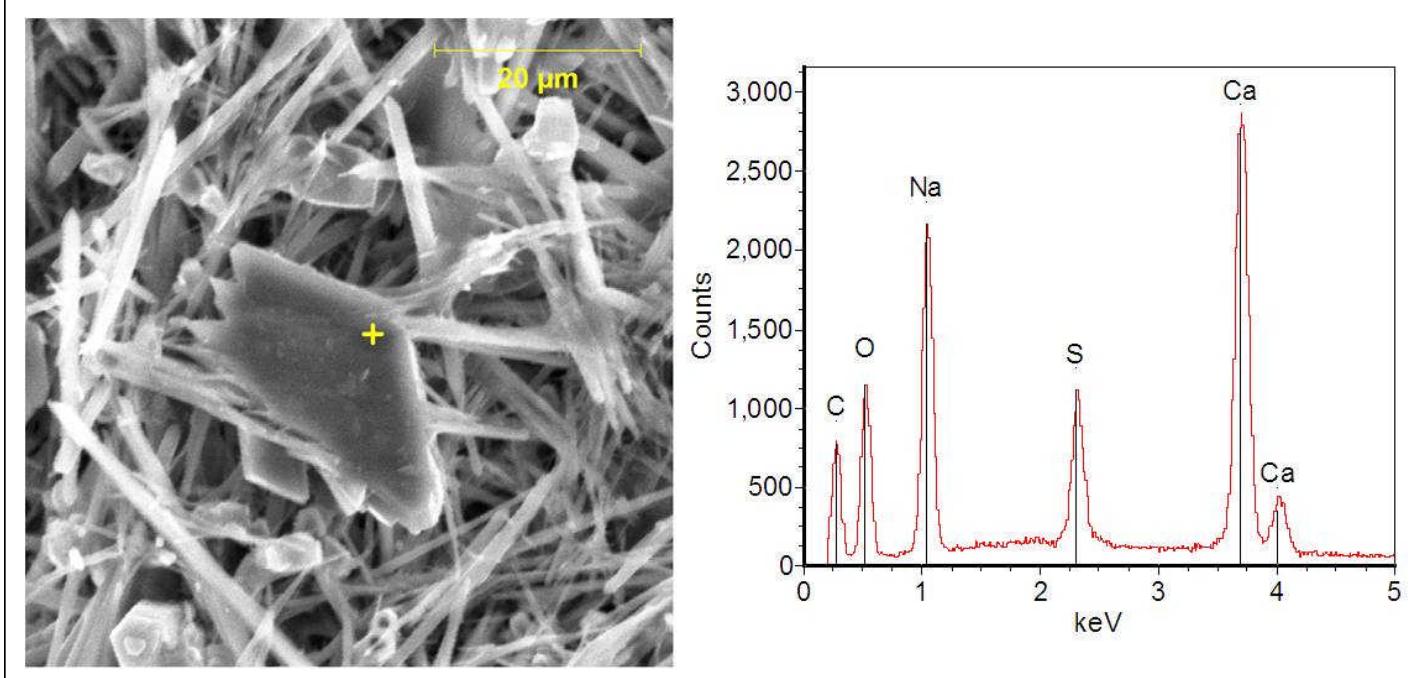


\section{Sample S11T011074: Solids from Boildown Sample CON $7\left(57.5 \% \mathrm{WVR}^{18^{\circ} \mathrm{C}}\right)$}

\section{XRD Results}

Nitratine $\left(\mathrm{NaNO}_{3}\right)$ was identified as a major phase and sodium nitrite $\left(\mathrm{NaNO}_{2}\right)$ as a minor phase in the sample; both are speculated to have crystallized from the interstitial liquid when the sample was dried. Thermonatrite $\left(\mathrm{Na}_{2} \mathrm{CO}_{3} \cdot \mathrm{H}_{2} \mathrm{O}\right)$ was identified as a minor phase and natrophosphate $\left[\mathrm{Na}_{7} \mathrm{~F}\left(\mathrm{PO}_{4}\right)_{2} \bullet 19 \mathrm{H}_{2} \mathrm{O}\right]$ as a trace phase of the sample.

\section{Chemical Name}

Sodium Nitrate

Sodium Nitrite

Sodium Carbonate Hydrate

Sodium Fluoride Phosphate Hydrate
Mineral Name

Nitratine

$---$

Thermonatrite

Natrophosphate
Formula

$\mathrm{NaNO}_{3}$

$\mathrm{NaNO}_{2}$

$\mathrm{Na}_{2} \mathrm{CO}_{3} \cdot \mathrm{H}_{2} \mathrm{O}$

$\mathrm{Na}_{7} \mathrm{~F}\left(\mathrm{PO}_{4}\right)_{2} \cdot 19 \mathrm{H}_{2} \mathrm{O}$
Relative Amount

Major

Minor

Minor

Trace

Figure XRD-4. Sample S11T011074.

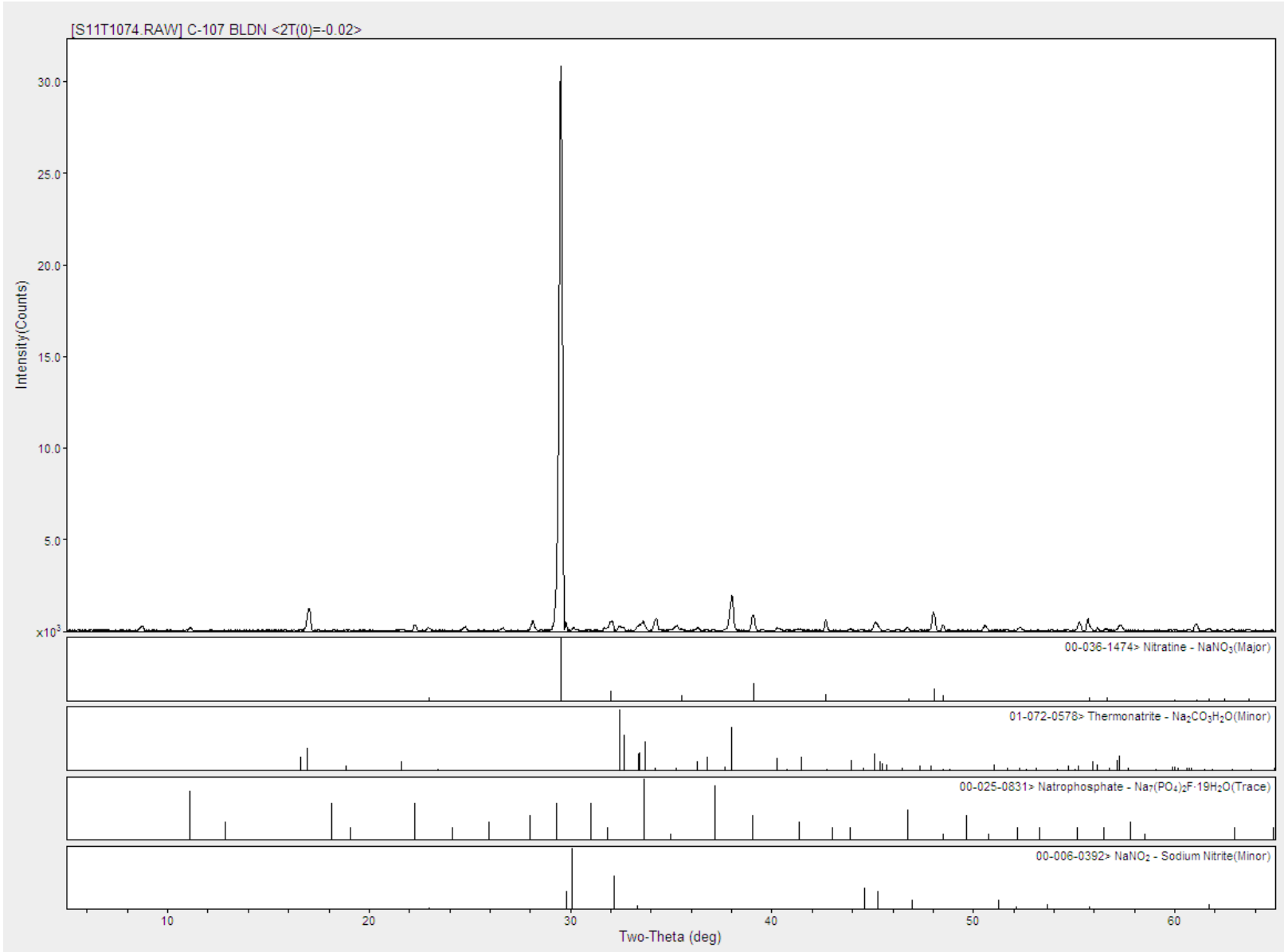




\section{PLM Results (S11T011074)}

Observed solids were mostly natroxalate needles and clusters. Some sodium carbonate and isotropic shards (presumably natrophosphate) were also identified. A minor amount of an unidentified, light-brown, fine-grained material was also observed.

Figure PLM-4. Sample S11T011074.

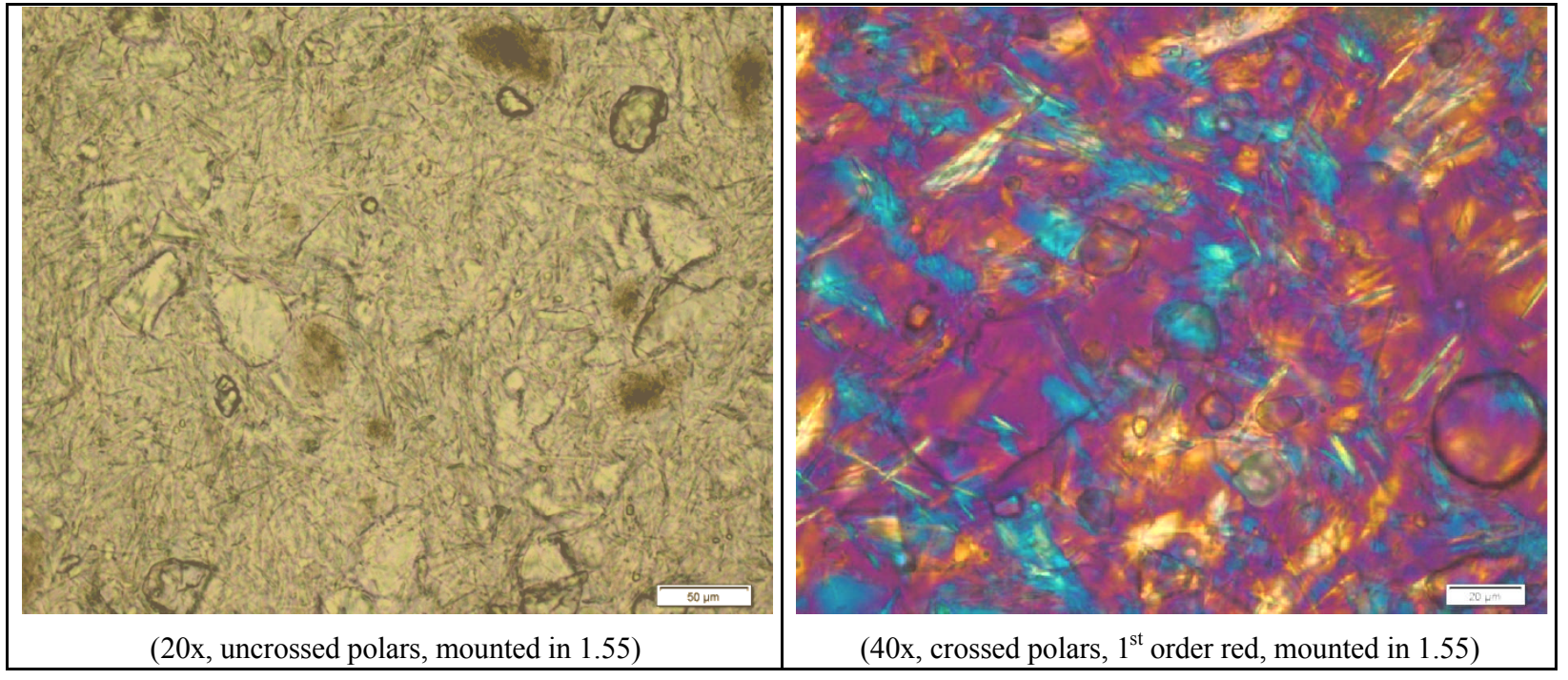




\section{SEM/EDX Results (S11T011074)}

A population of relatively small acicular and flake-like crystals was observed in the specimen. Populations of larger octahedral and rhombohedral crystals were also observed.

Figure SEM-17 shows an area on the SEM specimen where the continuous mat of small acicular and flake-like crystals was disrupted exposing a section of the polycarbonate filter. This location allowed the EDX analysis of these particles without the electron beam penetrating into underlying particles. The right image is a magnification of the area in the left image outlined with the yellow box. The EDX spectrum from Spot 1 indicates that the flake-like crystals are rich in sodium and oxygen. This elemental composition and morphology indentify these solids as sodium carbonate. The spectrum from Spot 2 indicates that the acicular solids, which are composed of sodium, sulfur, oxygen, and fluorine, are a sodium fluoride sulfate phase.

Figure SEM-17. SEM Images and EDX Spectra from Acicular and Flake-like Crystals in S11T011074.

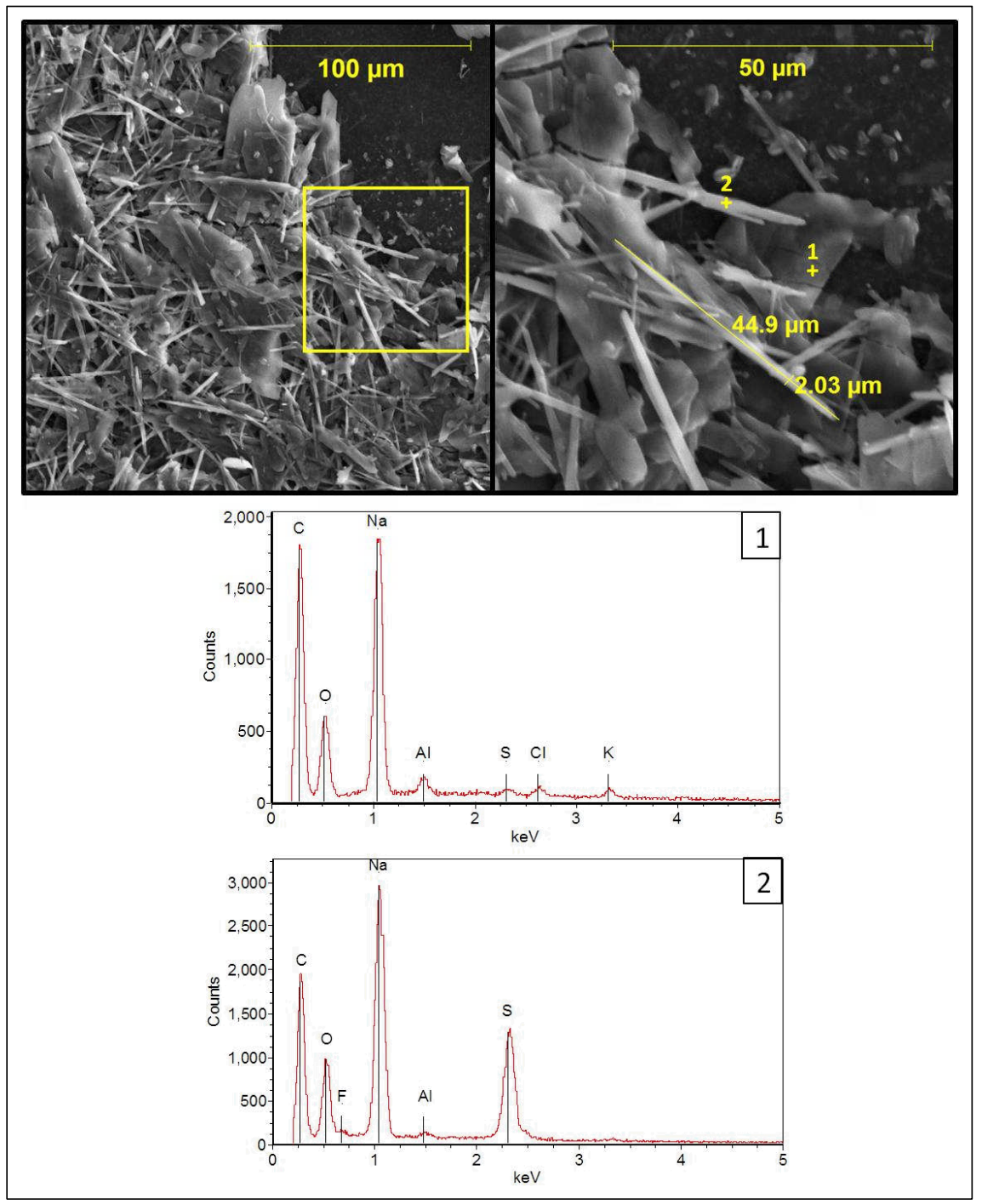


Further analysis of the acicular solids, Figure SEM-18, showed variations in sulfur and fluorine content. Trace amounts of aluminum and potassium were also detected in some of the particles. This suggests that more than one solid phase may be present in the acicular particles.

Figure SEM-18. SEM Image and EDX Spectra of Additional Acicular Particles from S11T011074.

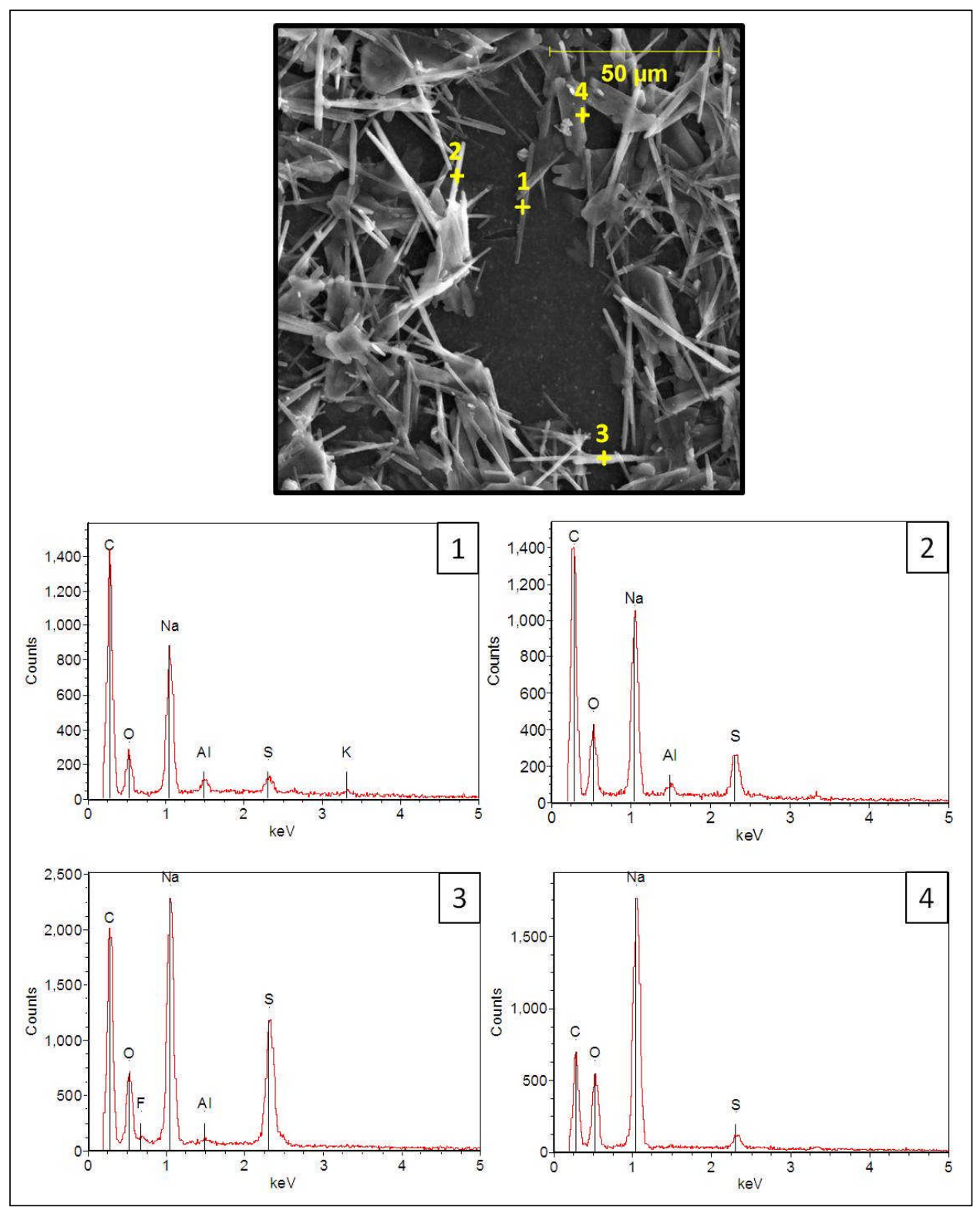


Large solid particles were scattered throughout the mat of smaller acicular and flake-like particulates. Figure SEM-19 shows one of these particles with a structure of twined rhombohedral crystals. The EDX spectrum shows the presence of sodium, oxygen, and nitrogen. The elemental content and morphology indicate this particle is sodium nitrate.

Figure SEM-19. SEM Image and EDX Spectrum of a Twinned, Rhombohedral Sodium Nitrate Particle.
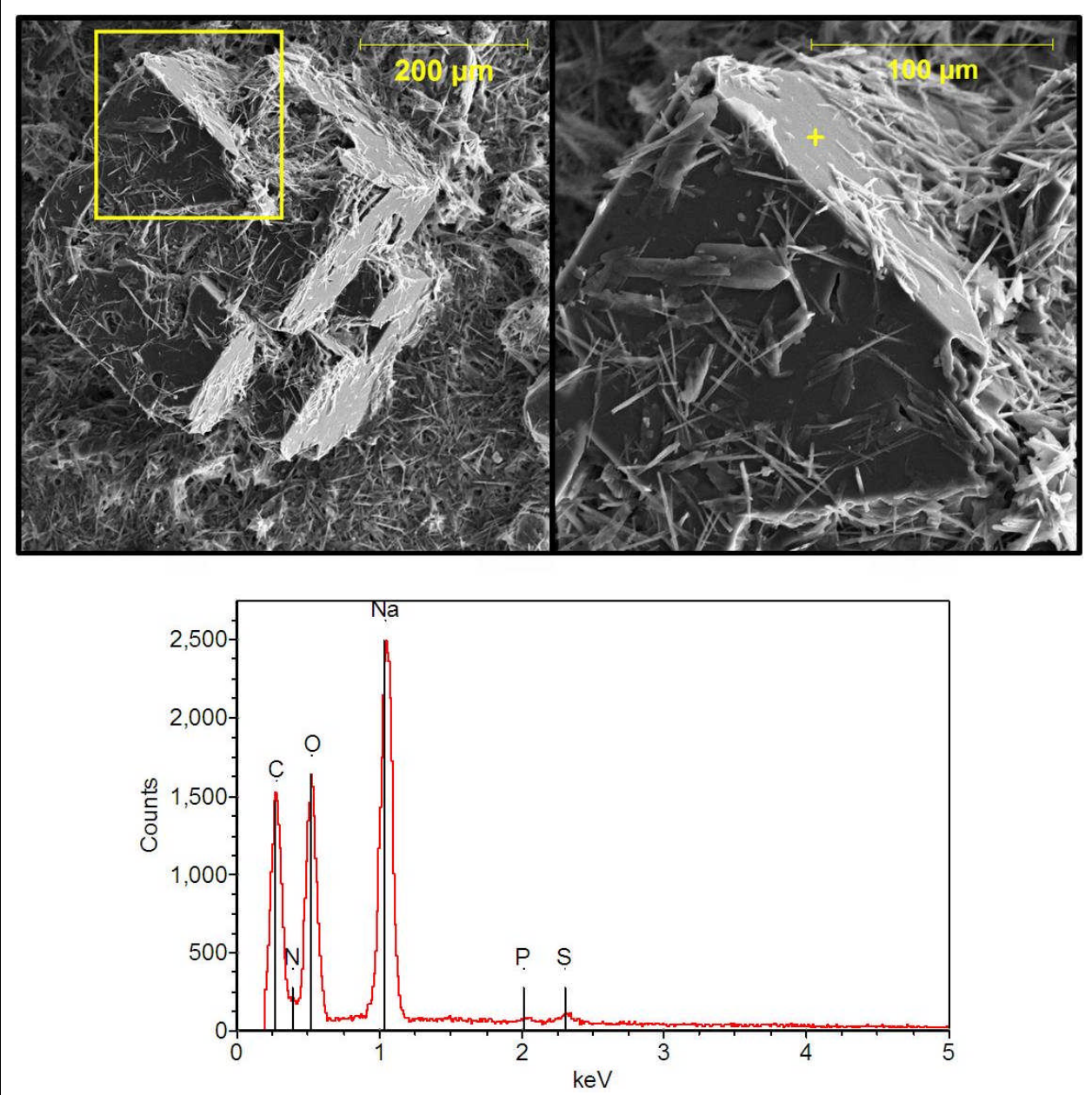
Figure SEM-20 shows an area with several of the larger particles. The rhombohedral crystal in Area 1 is sodium nitrate. The octahedral crystal in Area 2 is natrophosphate.

Figure SEM-20. SEM Images and EDX Spectra Showing the Two Types of Large Crystalline Solids in S11T011074.

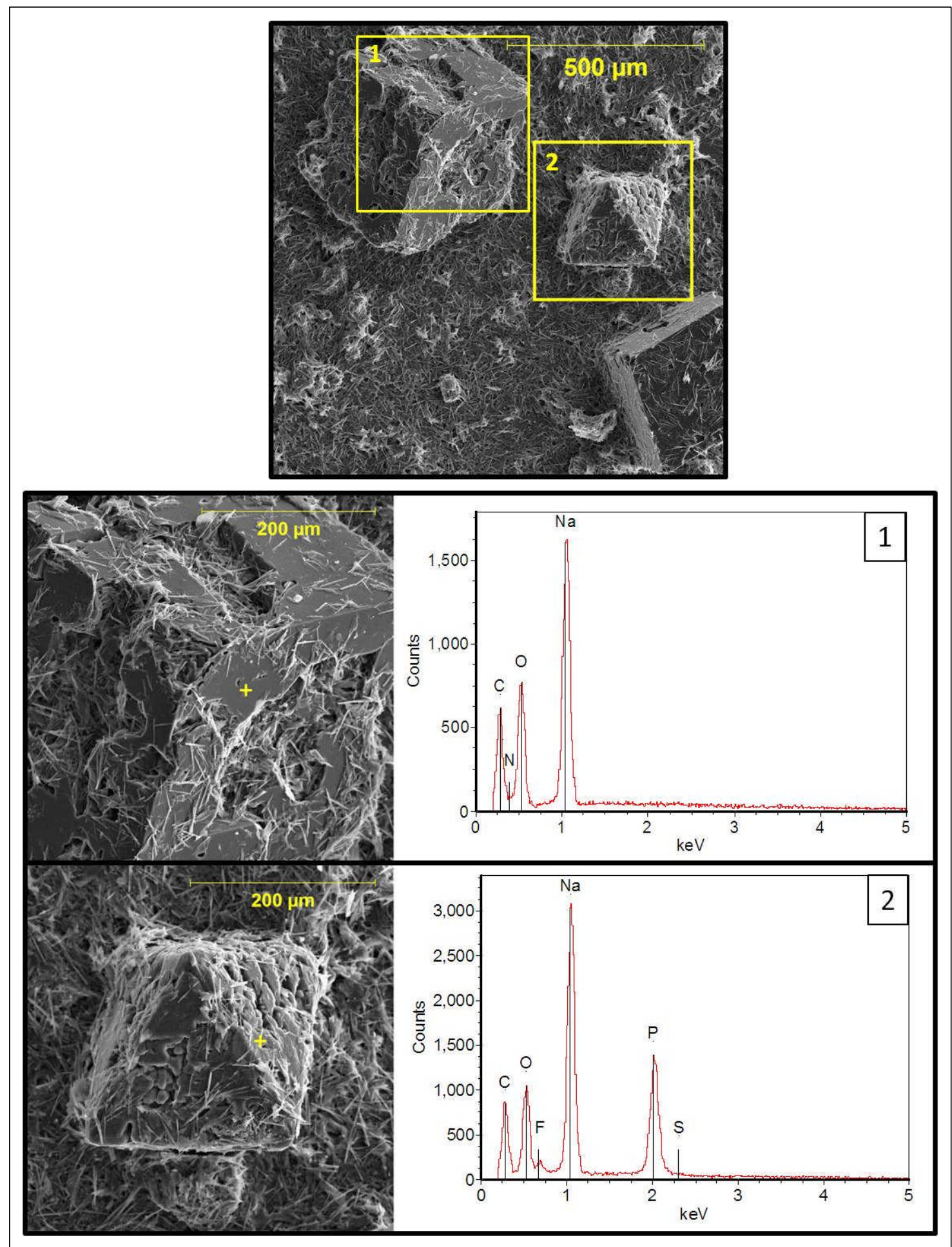




\section{Sample S11T011075: Solids from Boildown Step DIL $3\left(8.4 \% \mathrm{WVR}^{18^{\circ} \mathrm{C}}\right)$}

\section{XRD Results}

The major solid phase in the sample was natroxalate $\left(\mathrm{Na}_{2} \mathrm{C}_{2} \mathrm{O}_{4}\right)$. Nitratine $\left(\mathrm{NaNO}_{3}\right)$ was identified as a major phase and sodium nitrite $\left(\mathrm{NaNO}_{2}\right)$ as a minor phase in the sample; both are speculated to have crystallized from the interstitial liquid when the sample was dried. Natrite $\left(\mathrm{Na}_{2} \mathrm{CO}_{3}\right)$ and natrophosphate $\left[\mathrm{Na}_{7} \mathrm{~F}\left(\mathrm{PO}_{4}\right)_{2} \bullet 19 \mathrm{H}_{2} \mathrm{O}\right]$ were identified as a minor phases, and thermonatrite $\left(\mathrm{Na}_{2} \mathrm{CO}_{3} \cdot \mathrm{H}_{2} \mathrm{O}\right)$ as a trace phase of the sample.

\begin{tabular}{llll} 
Chemical Name & Mineral Name & Formula & Relative Amount \\
\hline Sodium Oxalate & Natroxalate & $\mathrm{Na}_{2} \mathrm{C}_{2} \mathrm{O}_{4}$ & Major \\
Sodium Nitrate & Nitratine & $\mathrm{NaNO}_{3}$ & Major \\
Sodium Nitrite & $\mathrm{NaNO}_{2}$ & --- & Minor \\
Sodium Carbonate & Natrite & $\mathrm{Na}_{2} \mathrm{CO}_{3}$ & Minor \\
Sodium Fluoride Phosphate Hydrate & Natrophosphate & $\mathrm{Na}_{7} \mathrm{~F}_{\left(\mathrm{PO}_{4}\right)_{2} \bullet 19 \mathrm{H}_{2} \mathrm{O}}$ & Minor \\
Sodium Carbonate Hydrate & Thermonatrite & $\mathrm{Na}_{2} \mathrm{CO}_{3} \cdot \mathrm{H}_{2} \mathrm{O}$ & Trace
\end{tabular}

Figure XRD-5. Sample S11T011075.

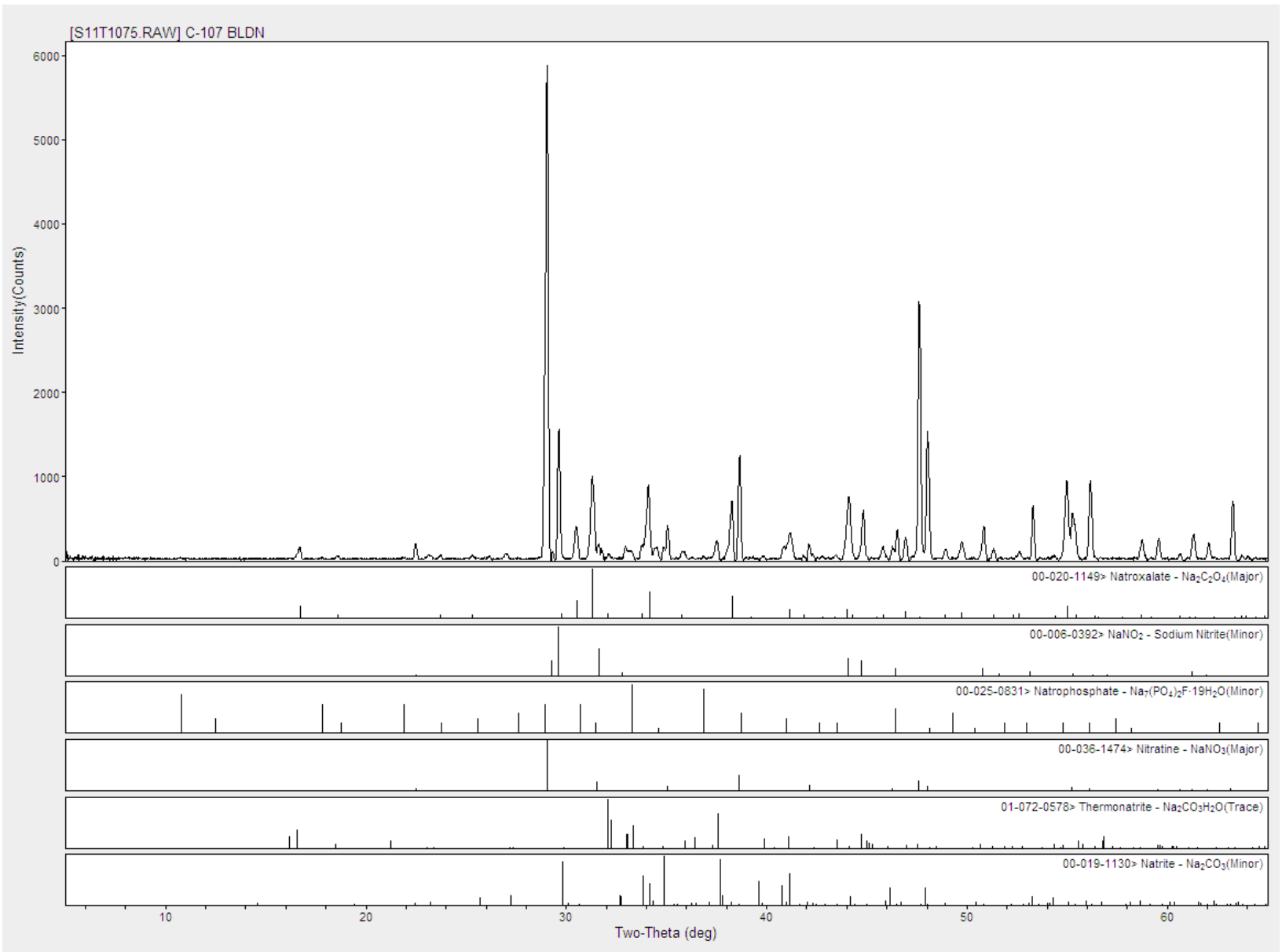




\section{PLM Results (S11T011075)}

Sodium oxalates (as individual needles and clusters) were observed. A lack of the isotropic shards (presumably natrophosphate) observed in Sample S11T011074 was noted.

Figure PLM-5. Sample S11T011075.

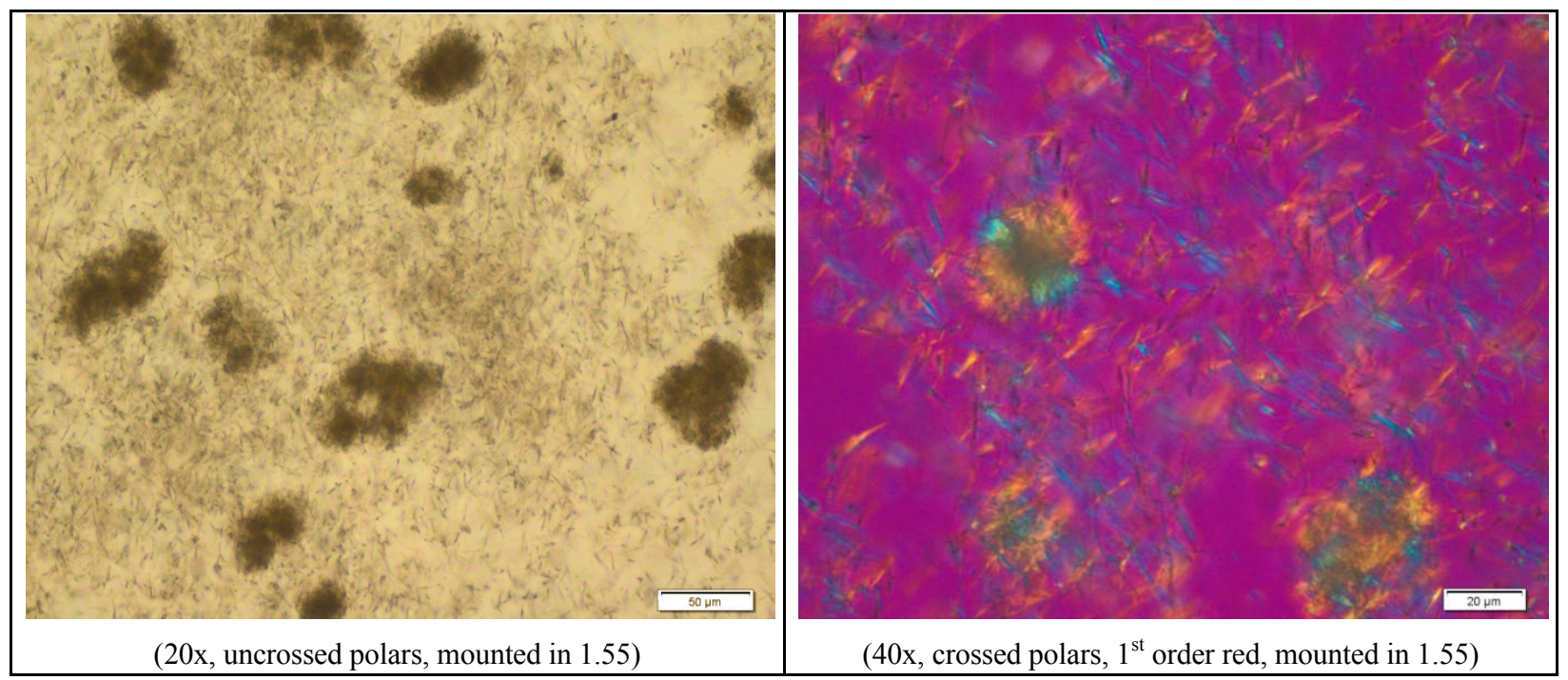




\section{SEM/EDX Results (S11T011075)}

The observed solids were mostly small $(\approx 15 \mu \mathrm{m}$ long), narrow, flat crystals. Figure SEM-21 shows an area SEM specimen where the particulates were dispersed well enough to acquire EDX spectra on three individual particles. A fourth EDX spectrum was acquired from a bare spot on the polycarbonate filter. All three EDX spectra from the particles showed consistent ratios of sodium, oxygen, and sulfur with trace aluminum. The bare spot showed sodium and trace aluminum. The observed morphology and EDX spectra are characteristic of sodium oxalate.

Figure SEM-21. SEM Image and EDX Spectra of Particles in S11T011075.

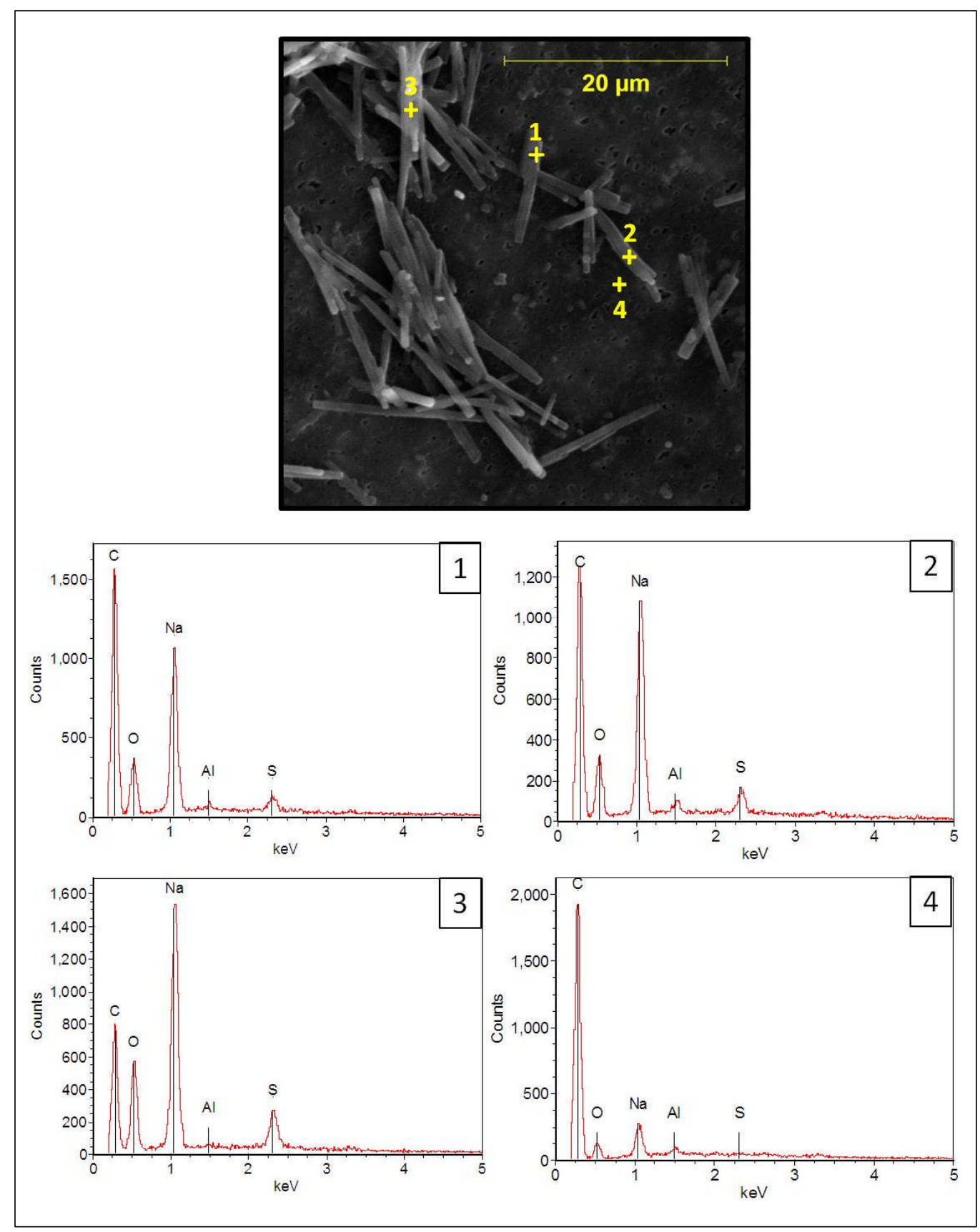


Figure SEM-22 is an image of the same area as Figure SEM-21 taken after the EDX spectra were acquired. The yellow circles highlight spots of beam damage. This phenomenon has been seen previously with oxalate crystals.

Figure SEM-22. Image of Particles from Figure SEM-21 Showing Beam Damage.

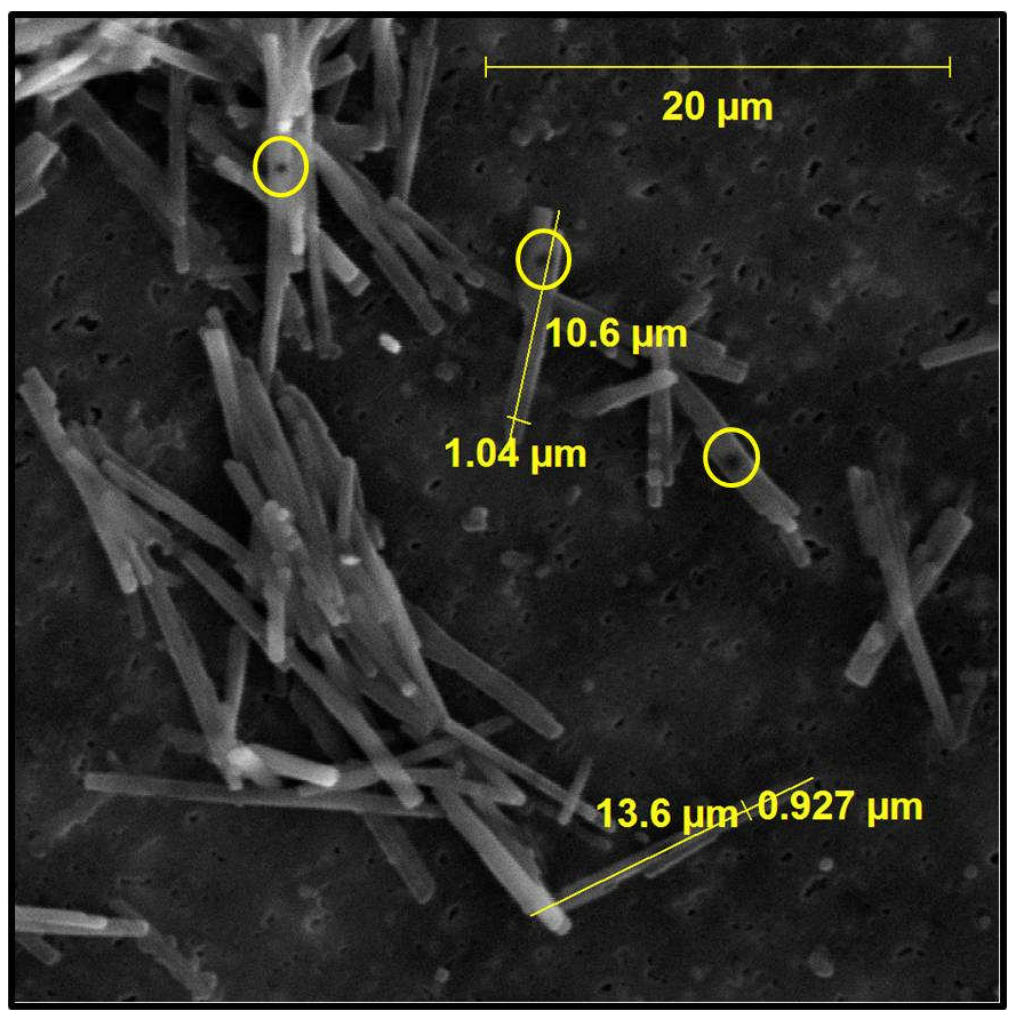

The acicular crystals in S11T011075 also displayed a tendency to cluster into $\approx 50-\mu \mathrm{m}$ diameter balls. Figure SEM-23 shows several of these clusters and a magnified image displaying in more detail how the particles are packed together. The EDX spectrum, acquired from one of the clusters, detected sodium and oxygen with trace aluminum. 
Figure SEM-23. SEM Images and EDX Spectrum of Particle Clusters in S11T011075.

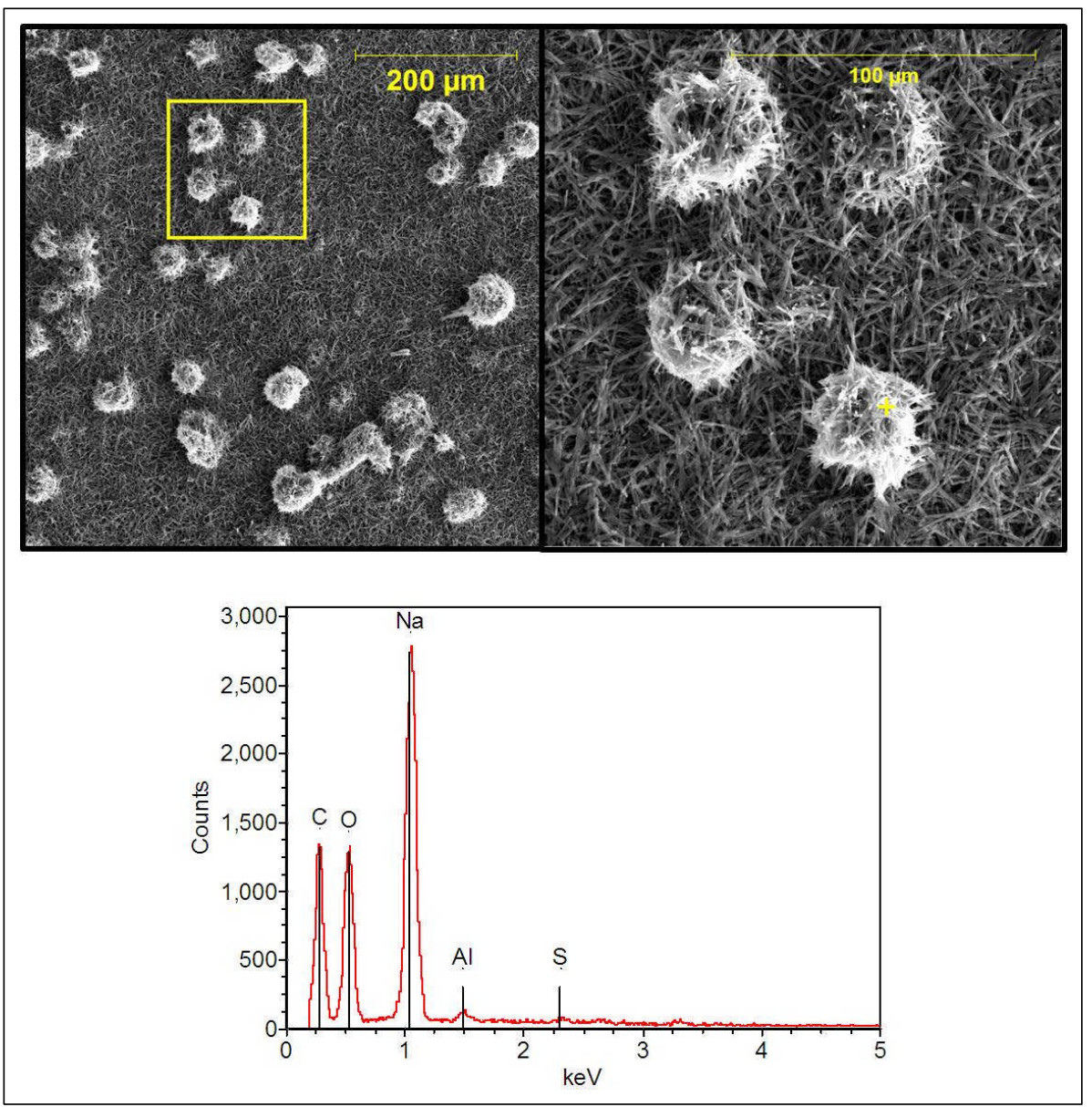

A vast majority of the solids in Sample S11T011075 were the acicular particles; however, a few flake-like particles were seen on top and embedded in the particulate mat. One of these flakelike particles is shown in Figure SEM-24. The EDX analysis detected sodium and oxygen, and, along with the morphology, suggested these solids were sodium carbonate.

Figure SEM-24. SEM Image and EDX Spectrum of a Flake-like Particle in S11T011075.
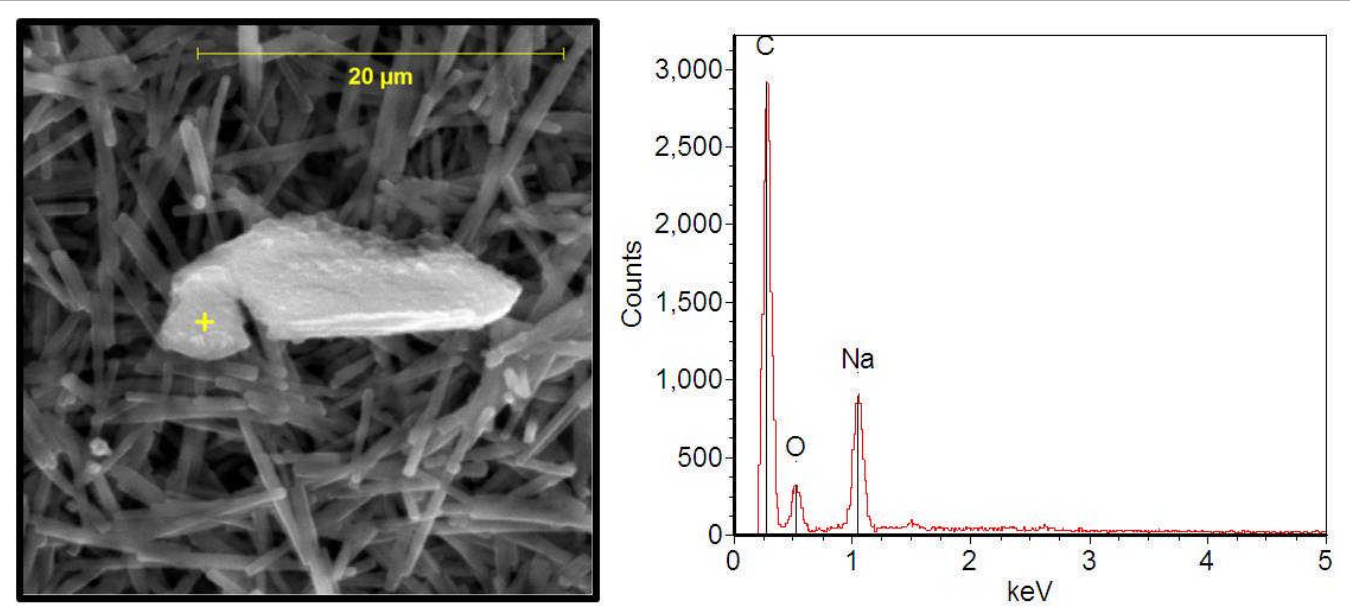


\section{REFERENCES}

ATS-LT-161-100, 222-S Laboratory Sample Preparation and Operating Procedure for Scanning Electron Microscopes, Rev. E-0, Washington River Protection Solutions LLC, Richland, Washington.

ATS-LT-507-101, 222-S Laboratory X-Ray Diffractometry (XRD), Rev. F-1, Washington River Protection Solutions LLC, Richland, Washington.

ATS-LT-519-107, 222-S Laboratory Polarized Light Microscopy, Rev. D-1, Washington River Protection Solutions LLC, Richland, Washington. 


\section{Electronically Approved by:}

UserName: Callaway, William (h0086007)

Title: APD Chemist

Date: Friday, 25 January 2013, 10:41 AM Pacific Time

Meaning: Approved by the author or delegate

UserName: Callaway, William (h0086007)

Title: APD Chemist

Date: Friday, 25 January 2013, 10:46 AM Pacific Time

Meaning: Approved by the customer or delegate

UserName: Clark, Glen (h0103701)

Title: QA

Date: Friday, 25 January 2013, 12:05 PM Pacific Time

Meaning: Approved by Quality Assurance or delegate

UserName: Hardy, Don (h0085161)

Title: Laboratory Facilities Manager

Date: Friday, 25 January 2013, 01:57 PM Pacific Time

Meaning: Approved by the Facility Manager or delegate

UserName: Seidel, Cary (h0009079)

Title: APD Manager

Date: Tuesday, 29 January 2013, 08:44 AM Pacific Time

Meaning: Approved by the Group Manager or delegate 


\section{DISTRIBUTION SHEET}

\begin{tabular}{l|l|l|}
\hline To: Distribution & From: 222-S Laboratory/Process Chemistry & Date: January 15, 2013 \\
\hline
\end{tabular}

Project Title/Work Order: LAB-RPT-12-00008, Rev. 0, Boildown Study on Supernatant Liquid Retrieved from AP-107 in May 2010

\begin{tabular}{|c|c|c|c|}
\hline \multirow[b]{2}{*}{ Name } & \multirow[b]{2}{*}{ MSIN } & \multicolumn{2}{|c|}{ Distribution } \\
\hline & & Electronic & Hard Copy \\
\hline \multicolumn{4}{|c|}{ Washington River Protection Solutions LLC } \\
\hline W. S. Callaway & T6-05 & $\mathrm{E}$ & \\
\hline J. M. Conner & R2-58 & E & \\
\hline P. G. Haigh & S5-14 & E & \\
\hline D. B. Hardy & T6-14 & $\mathrm{E}$ & \\
\hline D. L. Herting & T6-05 & $\mathrm{E}$ & \\
\hline J. Y. Houchin & K6-71 & $\mathrm{E}$ & \\
\hline J. Jo & H4-02 & E & \\
\hline N. W. Kirch & R2-58 & $\mathrm{E}$ & \\
\hline D. M. Nguyen & R2-58 & $\mathrm{E}$ & \\
\hline J. S. Page & T6-05 & E & \\
\hline J. R. Prilucik & T6-05 & $\mathrm{E}$ & \\
\hline J. H. Rasmussen & R2-58 & E & \\
\hline D. L. Renberger & T6-03 & E & \\
\hline J. G. Reynolds & R2-58 & E & \\
\hline C. L. Rosenkrance & R2-58 & E & \\
\hline C. M. Seidel & T6-14 & E & \\
\hline M. V. Shultz Jr. & S7-90 & E & \\
\hline R. W. Sosa & T6-05 & E & \\
\hline A. M. Templeton & R2-58 & E & \\
\hline E. M. Uytioco & R2-58 & E & \\
\hline \multicolumn{4}{|c|}{ Advanced Technologies and Laboratories International, Inc. } \\
\hline G. P. Ritenour & T6-01 & E & \\
\hline \multicolumn{4}{|l|}{ DOE, Office of River Protection } \\
\hline J. E. Cheadle & H6-60 & E & \\
\hline J. M. Johnson & H6-60 & E & \\
\hline DOE Reading Room & $\mathrm{H} 2-53$ & E & $\mathrm{H}$ \\
\hline
\end{tabular}

